\title{
THE HUMAN GENETIC \\ MUTANT CELL REPOSITORY
}

List of Genetic Variants, Chromosomal Aberrations and Normal Cell Cultures

Submitted to the Repository

Fourth Edition

October 1977

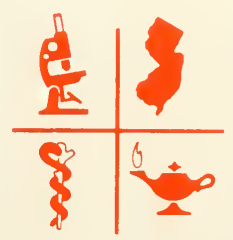

U.S. DEPARTMENT OF HEALTH, EDUCATION, AND WELFARE

Public Health Service

National Institutes of Health 
Marıne Biological Laboratory Library Woods Hole, Massachusetts

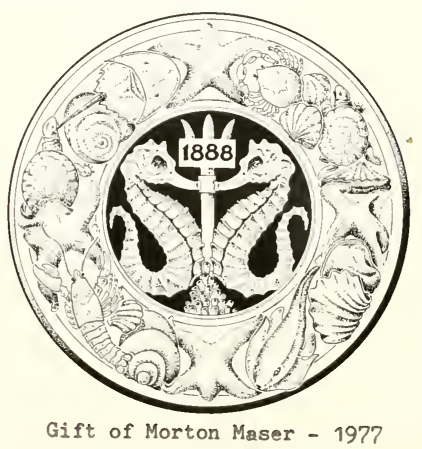


THE HUMAN GENETIC MUTANT CELL REPOSITORY

List of Genetic Variants, Chromosomal Aberrations

and Normal Cell Cultures

Submitted to the Repository

Fourth Edition

October 1977

INSTITUTE FOR MEDICAL RESEARCH

Copewood and Davis Streets

Camden, New Jersey 08103

$609-966-7377$

SPONSORED BY THE NATIONAL INSTITUTE OF GENERAL MEDICAL SCIENCES 
PREFACE

INTRODUCTION

PROCEDURES FOR ORDERING GENETIC MUTANT CULTURES

REQUIREMENTS

PROCEDURE

ADDRESS

FEES

SHIPPING CHARGES

HOW SHIPPED

DESCRIPTIVE DATA

REQUEST FOR CITATION AND REPRINTS

PUBLICATION OF DESCRIPTIVE ARTICLES ON CELL CULTURES

STORED IN THE REPOSITORY

ASSURANCE FORM

AGREEMENT ON LYMPHOID AND VIRUS TRANSFORMED CELLS

HUMAN GENETIC MUTANT CELL REPOSITORY MINIMUM SAFETY GUIDELINES

RECOMMENDED FOR WORKING WITH LYMPHOID AND VIRUS TRANSFORMED

HUMAN CELL LINES

SUPERVISION

PERSONNEL PRACTICES

PHYSICAL CONTROL PRACTICES

SUBMISSION OF SPECIMENS TO THE REPOSITORY

SUBMISSION SHEET

EXPLANATION OF THE CODE FOR RECORDING DATA IN THE COLUMNS OF

THE CATALOG

HUMAN FIBROBLAST CULTURES WITH BIOCHEMICAL MUTANT CONDITIONS

DISORDERS OF AMINO ACID METABOLISM

Alkaptonuria

Argininemia

Argininosuccinicaciduria

Citrullinuria (Citrullinemia)

Cystinosis

Homocystinuria (Cystathionine Synthase Deficiency)

Hyperglycinemia, Non-Ketotic

Hypermethioninemia

Hyperphenylalaninemia

Isovalericacidemia

Maple Syrup Urine Disease (Branched-Chain Ketoaciduria)

Phenylketonuria

Propionicacidemia (Hyperglycinemia with Ketoacidosis \& 
Amyloidosis

Aspartylglycosaminuria

Fructose-1,6-Diphosphatase Deficiency 31

Fucosidosis

Galactosemia (Kinase Deficiency)

Galactosemia (Transferase Deficiency)

Glucose-6-Phosphate Dehydrogenase Deficiency and Variants

Glycogen Storage Diseases

Type I - Von Gierke Disease

Type II - Pompe Disease

Type III - Debranching Enzyme Deficiency

Type IV - Andersen Disease

Type V - McArdle Disease

Type VI - Hers Disease

Types VIII, IX - Phosphorylase Kinase Deficiency

$\begin{array}{ll}\text { Type II - I-Ce11 Disease } & 35\end{array}$

Type III - Pseudo-Hurler Polydystrophy 36

Type IV $\quad 36$

Mucopolysaccharidoses $\quad 36$

Type IH - Hurler Syndrome $\quad 36$

Type IH/S - Hurler/Scheie $\quad 37$

$\begin{array}{ll}\text { Type IS - Scheie Syndrome } & 37\end{array}$

$\begin{array}{ll}\text { Type II - Hunter Syndrome } & 38\end{array}$

Type IIIA - Sanfilippo Syndrome, A 38

Type IIIB - Sanfilippo Syndrome, B 39

Type IV - Morquio Syndrome 39

Type VI - Maroteaux-Lamy Syndrome 39

Type VII - Beta-Glucuronidase Deficiency 40

$\begin{array}{ll}\text { Winchester Disease } & 40\end{array}$

Neuraminidase Deficiency (Acid Sialidase Deficiency) 40

Phosphoglycerate Kinase Deficiency 40

DISORDERS OF LIPID METABOLISM $\quad 40$

Carnitine Palmitoyl-CoA Transferase Deficiency 40

Ceroid-lipofuscinosis $\quad 40$

Cholesterol Ester Storage Disease of Liver 40

Fabry Disease (Diffuse Angiokeratoma) 40

Farber Lipogranulomatosis 41 
Gaucher Disease

Type 2 - Infantile

Type $1 \& 3$ - Juvenile \& Adult

GM1 Gangliosidosis - Type I

GM2 Gangliosidoses

$A B$ Variant

Type I - Tay-Sachs Disease

Type II - Sandhoff Disease

Hyperlipoproteinemia

Type II - Familial Hypercholesterolemia 42

Krabbe Disease (Globoid Cell Sclerosis)

Metachromatic Leukodystrophy

Infantile

Adult

Multiple Sulfatase Deficiency Disease

Niemann-Pick Disease

Type A

Type B

Type C

Type Unspecified

Refsum Disease

Schilder Disease

Wolman Disease

DISORDERS OF NUCLEOTIDE AND NUCLEIC ACID METABOLISM

Adenosine Deaminase Deficiency (Immune Deficiency

$$
\text { Disease) }
$$

Adenosine Phosphoribosyl Transferase Deficiency

Inosine Triphosphate Pyrophosphohydrolase (ITPase)

Deficiency

Lesch-Nyhan Syndrome (HGPRT Deficiency)

Orotic Aciduria

Xeroderma Pigmentosum

Complementation Group A

Complementation Group C

Complementation Group D

Complementation Group E

Complementation Group Undetermined

Acatalasia (Acatalasemia)

Menkes Syndrome (Kinky Hair Disease)

Porphyria

Acute Intermittent Porphyria

Cutanea Tarda

Hereditary Coproporphyria 
UISORDERS OF UNCERTAIN BIOCHEMICAL ETIOLOGY

Adrenal Hyperplasia (Adrenogenital Syndrome) - Type III 51

Adrenoleukodystrophy (Addison Disease and Cerebral

$$
\text { Sclerosis) }
$$

Agammaglobulinemia, X-Linked

Alzheimer Disease of Brain

Basal Cell Nevus Syndrome

Beckwith-Wiedemann Syndrome (EMG Syndrome)

Campomelic Dwarf

Canavan Disease (Spongy Degeneration of the CNS)

Cartilage-Hair Hypoplasia (Metaphyseal Chondrodysplasia, McKusick Type)

CNS Disorder, Unclassified, Hereditary

Chediak-Higashi Syndrome

Chondrodyst rophy

Cockayne Syndrome

Conradi Syndrome (Chondrodysplasia Punctata)

Corneal Dystrophy, Macular Type

Cornelia de Lange Syndrome

Cut is Laxa

Cystic Fibrosis (Mucoviscidosis)

Diabetes Mellitus

Dysautonomia (Riley-Day Syndrome)

Dyskeratosis Congenita

Dystonia Musculorum Deformans

Ehler-Danlos Syndrome

Type I

Type II

Type VI - (Hydroxylysine-Deficient Collagen)

Type Unclassified

Giant Mitochondrial Disease

Gouty Arthritis

Huntington Chorea

Hypophos phat asia

Ichthyosis Congenita

Incontinentia Pigmenti

Leigh Encephalomyelopathy

Lowe Oculocerebrorenal Syndrome 59

Marfan Syndrome

Mental Retardation, X-Linked 59

Muscular Dystrophy 
Osteogenesis Imperfecta

Papular Mucinosis

Potter Syndrome (Renal Agenesis)

60

Progeria

60

Retinoblastoma

61

Schizophrenia and Psychiatric Disorders

61

Sea-Blue Histiocyte Disease

61

Spinocerebellar Ataxia

61

Testicular Feminization Syndrome $\quad 62$

Thanatophoric Dwarfism $\quad 62$

Tuberous Sclerosis

62

Werdnig-Hoffman Disease

Wilson Disease (Hepatolenticular Degeneration)

Wiskott-Aldrich Syndrome

62

Zellweger Syndrome

HUMAN FIBROBLAST CULTURES WITH CHROMOSOMAL ABERRATIONS

63

SYNDROMES WITH INCREASED CHROMOSOME BREAKAGE

At axia-Telangiectasia

Bloom Syndrome

Fanconi Anemia (Pancytopenia)

TRANSLOCATIONS

Chromosome 1

Chromosome 2

Chromosome 3

Chromosome 4

Chromosome 5

Chromosome 6

Chromosome 7

Chromosome 8

Chromosome 9

Chromosome 10

Chromosome 11

Chromosome 12

Chromosome 13

Chromosome 14

Chromosome 15

Chromosome 16

Chromosome 17

Chromosome 18

Chromosome 19

Chromosome 20

Chromosome 21

Chromosome 22 
INVERSIONS

Chromosome 2

Chromosome 3

89

Chromosome 4

89

Chromosome 9

89

Chromosome 10

90

Chromosome 13

MONOSOMIES

Chromosome 21

92

Chromosome $\mathrm{X}$

TRISOMY/POLYSOMY

Chromosome 8

Chromosome 9

Chromosome 10

Chromosome 13

93

Chromosome 18

Chromosome 21

Chromosome 22

Chromosome $\mathrm{X}$

Chromosome Y

TRIPLOIDY

DELETION/RING/ISOCHROMOSOME

Chromosome 1

Chromosome 2

Chromosome 3

Chromosome 4

Chromosome 5

Chromosome 6

Chromosome 8

Chromosome 9

Chromosome 11

Chromosome 13

Chromosome 16

TERATOMA

GONADAL DYSGENESIS

BIOCHEMICAL MARKERS

APPARENTLY NORMAL HUMAN FIBROBLAST CELL CULTURES 
Fabry Disease (Diffuse Angiokeratoma)

Homocystinuria (Cystathionine Synthase Deficiency) 105

Hunter Syndrome

Lesch-Nyhan Syndrome (HGPRT Deficiency)

Metachromatic Leukodystrophy

CHROMOSOMAL ABERRATIONS

Translocation

105

Inversions

106

Trisomy

106

APPARENTLY NORMAL

106

HUMAN LYMPHOCYTE CULTURES WITH BIOCHEMICAL MUTANT CONDITIONS

107

DISORDERS OF AMINO ACID METABOLISM

107

Argininemia

107

Citrullinuria (Citrullinemia)

107

Cystathionuria

107

Homocystinuria (Cystathionine Synthase Deficiency)

108

Maple Syrup Urine Disease (Branched-Chain Ketoaciduria) 108

Phenylketonuria

108

DISORDERS OF CARBOHYDRATE METABOLISM

108

Fucosidosis

108

Galactosemia (Transferase Deficiency)

109

Glycogen Storage Disease

109

Type II - Pompe Disease

109

Mucopolysaccharidosis

109

Type IH - Hurler Syndrome

109

Type IH/S - Hurler/Scheie

109

Type IIIA - Sanfilippo Syndrome, A

109

Type VI - Maroteaux-Lamy Syndrome

109

DISORDERS OF LIPID METABOLISM

109

Abetalipoproteinemia

109

Gaucher Disease

110

Hyperlipidemia

110

Hyperlipoproteinemia

110

Type II - Familial Hypercholesterolemia

110

Metachromatic Leukodystrophy

110

DISORDERS OF NUCLEOTIDE AND NUCLEIC ACID METABOLISM

111

HGPRT Deficiency

111

Inosine Triphosphate Pyrophosphohydrolase (ITPase)

Deficiency

Lesch-Nyhan Syndrome (HGPRT Deficiency)

111

Xeroderma Pigmentosum

111

111

OTHER DISORDERS OF KNOWN BIOCHEMISTRY

111

Menkes Syndrome (Kinky Hair Disease)

111

Porphyria

111

Acute Intermittent Porphyria 


\section{DISORDERS OF UNCERTAIN BIOCHEMICAL ETIOLOGY}

Adrenal Hyperplasia (Adrenogenital Syndrome) - Type III 112

Basal Ce11 Nevus syndrome

Cockayne Syndrome

Cystic Fibrosis (Mucoviscidosis)

Diabetes Mellitus

Dysautonomia (Riley-Day Syndrome)

Dyskeratosis Congenita

Dystonia Musculorum Deformans

Huntington Chorea

Hyper IgM

Neurofibromatosis (Von Recklinghausen Disease)

Persistance of Fetal Hemoglobin (Hemoglobin F)

Schizophrenia and Psychiatric Disorders

Sea-Blue Histiocyte Disease

Tuberous Sclerosis

Waldenstrom Macroglobulinemia

HUMAN LYMPHOCYTE CULTURES WITH CHROMOSOMAL ABERRATIONS

SYNDROME WITH INCREASED CHROMOSOME BREAKAGE

Ataxia-Telangiectasia

TRANSLOCATIONS

TRI SOMY / POLY SOMY

$\begin{array}{ll}\text { Allergic Asthmatic } & 121\end{array}$

$\begin{array}{ll}\text { Leukeria } & 121\end{array}$

Multiple Myeloma $\quad 121$

APPARENTLY NORMAL HUMAN LYMPHYOCYTE CULTURES 122

SV40 VIRUS TRANSFORMED CELL CULTURES

Galactosemia (Transferase Deficiency)

Lesch-Nyhan Syndrome (HGPRT Deficiency)

Apparently Normal

ANIMAL CELL CULTURES

Mouse

Syrian Baby Hamster

Chinese Hamster

AGING CELL REPOSITORY CULTURES

Alzheimer Disease of Brain

Bloom Syndrome

Cowden Disease

Lowe Oculocerebrorenal Syndrome 126

Mulibrey Nanism 
Translocation

Xeroderma Pigmentosum

TUMOR PATIENTS

Chronic Myelogenous Leukemia

Glomus Tumor

Multiple Myeloma

Neuroblastoma

Osteogenic Sarcoma

Retinoblastoma

Wilms Tumor

APPARENTLY NORMAL CULTURES

SPECIALLY CHARACTERIZED DIPLOID CELL CULTURES

APPENDIX C - REPOSITORY PUBLICATIONS IN CYTOGENET. CELL GENET. 
Preface to the Fourth Edition

Acquisition of cell cultures by the Repository and shipment of cell cultures to investigators both continue to increase at an accelerating rate as shown on the graph which follows this preface. In addition to many new cell cultures and supplementary data on others, the present edition contains new features. McKusick's numbers, where applicable, are inserted immediately following the name of each disease. A bracket is placed around cell cultures from members of a family group. HL-A antigens have been determined on many of the lymphocyte cell cultures and this data is recorded in the table on pages 161-163. Eleven cultures are available from both this Repository and from the American Type Culture Collection in Rockville, Maryland under a different numerical designation. To avoid confusion we have 1 isted the ATCC designation under "Remarks".

Camden, N.J., August 1977 Lewis L. Corie11, M.D, Ph.D. Arthur E. Greene, D.Sc. 
THE HUMAN GENETIC MUTANT CELL REPOSITORY

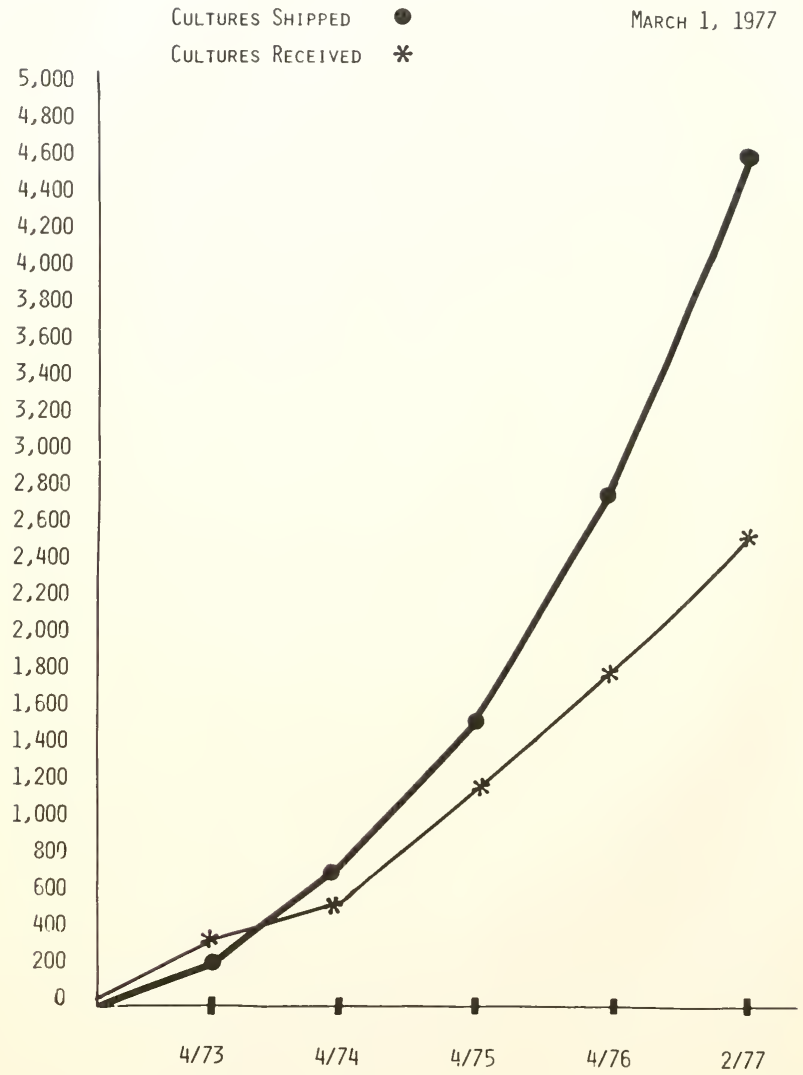




\section{INTRODUCTION}

The Human Genetic Mutant Cell Repository established in 1972 by the National Institute of General Medical Sciences at the Institute for Medical Research, Camden, New Jersey, contains low passage skin fibroblast, lymphoblast, amniotic fluid cell, and a few animal cell cultures stored in liquid nitrogen from hereditary diseases including those with biochemical and chromosome abnormalities and normal controls. Cell cultures stored in the Repository are verified for freedom from contamination, species of origin, karyotype, viability and expression of the biochemical or chromosomal defect. These cells are available to organizations or individuals engaged in healthrelated research or health delivery concerning early diagnosis, prevention, treatment, counseling and research for control of some of the 2,000 or more inherited diseases that afflict human beings. The problems in many of these diseases are gene abnormalities which alter one or more chemical steps in the normal metabolic sequence of cells. The application of techniques for detailed study of these cellular chemical processes in cell culture is leading to a wealth of information about human genetics and improvement in the prevention and treatment of genetic diseases and probably many other diseases in which genetic factors are not yet recognized to play a significant role. The Repository program has been developed by the National Institute of General Medical Sciences with the help of a scientific advisory committee which periodically reviews the progress of the 
collection and provides advice on the acquisition of cell 1 ines.

Cell cultures are 1 isted alphabetically under cell type and biochemical or morphological abnormalities including the genetic mutant (GM) repository number, tissue, passage number, culture medium, submitter, age, sex, race, genetic status, verification and remarks.

Appreciation is expressed to the many investigators who help the NIGMS Advisory Committee and the Repository staff select representative subjects and help validate the genetic defects by providing clinical and laboratory data or assays on the cell culture.

Interested investigators are invited to utilize the Repository as a source of genetic mutant cell cultures.

Lewis L. Corie11, M.D., Ph.D. Arthur E. Greene, D. Sc. 


\section{REQUIREMENTS}

The cells are distributed only to qualified professional persons who are associated with recognized research, medical, educational or industrial organizations engaged in health-related research or health delivery. Before fibroblast cells can be shipped, the assurance form (Par. 10) must be signed and returned to the Repository. This is adequate for most cell cultures in the Repository. However, lymphoblast or virus transformed cell cultures require prior agreement to observe the Minimum Safety Guidelines (Page 12) and return of the signed Agreement on Lymphoid and Virus Transformed Cells (Par. 11). These forms may be obtained by writing to the Repository, or may be photocopied.

\section{PROCEDURE}

Requests for cell cultures must be submitted on institutional purchase forms including purchase order numbers. Purchasing agents should indicate the name of the investigator on such orders. Telephone orders will be accepted when accompanied by a purchase order number, and should be confirmed within several days by letter. Each culture requested should include the Genetic Mutant Repository number (GM number), and the diagnosis.

\section{ADDRESS}

All requisitions should be addressed to: 
Dr. Arthur E. Greene

The Human Genetic Mutant Cell Repository

Institute for Medical Research

Copewood and Davis Streets

Camden, New Jersey 08103

Telephone 609-966-7377

\section{FEES}

The fee for each $25 \mathrm{~cm}^{2}$ flask of cells is $\$ 20.00$ to nonprofit institutions, but is reduced one dollar per culture up to 5 orders received simultaneously i.e. $\$ 19.00$ each for an order of 2 cultures, $\$ 16.00$ each for 5 or more. Frozen ampules are not shipped, because experience has shown much better success in shipping freshly revived flask cultures. Mass production of cell cultures is not a function of the Repository, (See Appendix E). The Repository is designed to provide only seed cultures. It is suggested that the recipient store aliquots of early passages in liquid nitrogen as insurance against contamination, accidents, artifacts associated with aging, and loss of the culture.

\section{SHIPPING CHARGES}

The shipping charges are prepaid and will be added to the invoice at the time of billing. 
All cell cultures are grown and frozen in antibiotic-free media to aid in detection and prevention of contamination. Cell cultures in the Repository have been tested and found free of mycoplasma, bacteria, molds and fungi during characterization, at the time of frozen storage, and after recovery from 1 iquid nitrogen. When an order is received, a frozen ampule is usually recovered from liquid nitrogen on the following Thursday and the medium is changed on Friday. The following Monday, the culture is inspected, the medium is removed and the T25 flask is filled with fresh medium, packed and shipped, usually by air mail special delivery. The flask is enclosed within two watertight plastic envelopes within a styrofoam box in a cardboard mailer to prevent leakage, overheating or freezing during shipment. A return postcard is enclosed. Please return the postcard with notations about the condition on arrival. Pertinent suggestions to improve the effectiveness of the Repository are appreciated.

\section{DESCRIPTIVE DATA}

Each shipment contains descriptive data about the cell culture, suggested directions for cell growth and pertinent references when available. Upon receipt cell cultures should be placed in the incubator at $37^{\circ} \mathrm{C}$ for a few hours or overnight to permit recovery from damage which may have occurred during shipment. 
It will be greatly appreciated and will make the cell collection more valuable if the source and Repository number is cited in publications in which cell cultures from the Human Genetic Mutant Cell Repository are used. The Repository would appreciate receiving a reprint of such publications.

\section{PUBLICATION OF DESCRIPTIVE ARTICLES ON CELL CULTURES STORED}

IN THE REPOSITORY

Concise descriptions of some of the cultures stored in the Repository are published after characterization in Cytogenetics and Cell Genetics under the name of the individual originally submitting the culture or biopsy. These descriptions include brief clinical histories, assay methods when applicable, family pedigrees, full or partial karyotypes in the case of chromosomal aberrations, and references to previous work involving the cell lines. For a listing of these concise papers, see Appendix C, page 153 . 
Before cells can be shipped from the Genetic Mutant Cell Repository the recipient institution must submit a purchase order number and agree to the 1 imitations 1 isted below. This agreement must be renewed annually. Please sign and return originial to the Institute for Medical Research, Copewood Street, Camden, New Jersey 08103.

\section{ASSURANCE}

As purchaser of cell cultures from the Genetic Mutant Cell Repository we agree that such cells, their progeny, or derivatives will not be used in human experimentation. It is further agreed that if such use is planned, the purchaser will first obtain prior written approval of the Project officer, N01-GM-6-2119, National Institute of General Medical Sciences.

It is further agreed that cell cultures obtained from the Genetic Mutant Cell Repository will not be resold, but they may be replicated by a third party for the original purchaser. The third party shall not be allowed to resell other than to the original purchaser furnishing the material for replication and the third party shall not use such cells for human experimentation.

Name of Institution

Signature of Authorized official
Name of Principal Investigator $\overline{\text { Date }}$

Signature of Principal Investigator
Date 
This document must be appropriately completed and exchanged before lymphoid and virus transformed cell lines can be transferred from the Human Genetic Mutant Cell Repository to your laboratory.

\section{AGREEMENT}

The potential hazardous nature of these human cell lines is unknown. However, in view of this lack of knowledge, it is appropriate that the scientific community be made aware that a potential hazard may exist. Therefore, we recommend that the enclosed guidelines for laboratory procedure be adhered to in the handling of lymphoid and virus transformed cell lines. They are also recommended for handling all cell cultures.

It is understood that you will not further distribute cell lines sent to you to laboratories not under your direct supervision. It is further agreed that all cultures obtained from the Human Genetic Mutant Cell Repository may only be replicated by a third party if the third party also executes an Agreement on Lymphoid and Virus Transformed Cells agreeing to follow the Minimum Safety Guidelines.

As purchaser of cell cultures from the Human Genetic Mutant Cell Repository we agree that such cells, their progeny, or derivatives will not be used in human experimentation. It is 
further agreed that if such use is planned, the purchaser will first obtain prior written approval of the Project officer, N01-GM-6-2119, National Institute of General Medical Sciences.

This agreement, when appropriately executed, will be on file and will qualify you to receive lymphoid and virus transformed cell lines from the Human Genetic Mutant Cell Repository.

\section{AGREEMENT ON LYMPHOID AND VIRUS TRANSFORMED CELLS}

We the signatories below, have read and understand this document and agree that in the handling of cell lines furnished, we will adhere to the procedures and recommendations outlined in the foregoing and the attached "Minimum Safety Guidelines Recommended for Working with Lymphoid and Virus Transformed Human Cell Lines."

A. For the recipient laboratory:

Investigator: Signature Date Title

Head of Laboratory or Immediate Supervisor:

Signature Date Title Addres s

B. For Human Genetic Mutant Cell Repository: Date Title 
III. HUMAN GENETIC MUTANT CELL REPOSITORY

MINIMUM SAFETY GUIDELINES

RECOMMENDED FOR WORKING WITH LYMPHOID

AND VIRUS TRANSFORMED HUMAN CELL LINES*

A. Supervision

1. Administrative Responsibilities

a. Responsibility of Management

Management should establish a biohazards committee to institute and enforce a health and safety policy which includes a specific safety program for work involving human cell 1 ines. The program should meet applicable federal, state and local regulations and include safety training, maintenance of accident records, and provisions for emergency treatment.

b. Responsibility of the Principal Investigator

The principal investigator is responsible for the preparation of safety protocols for the research program under his direction. The protocols should include appropriate procedures for use, storage, decontamination, disposal and emergency treatment. The protocols should be approved by the biohazards

*These guidelines were developed on February 11, 1974 at a special meeting at the National Institutes of Health attended by representatives from the office of Biohazards of NCI, NIAID, NIGMS and the Advisory Committee to the Human Genetic Mutant Cell Repository. 
committee and discussed with the research staff before starting the research program.

2. Medical Surveillance and Screening

a. Physical Examinations

Appropriate pre-employment and periodic medical examinations are desirable for persons working with human ce11 lines.

b. Work Restrictions

Persons having reduced immunologic competency should be restricted from working with these human cell lines.

c. Serum Collection

Serum should be collected at the time of the pre-employment physical to establish a baseline reference. Serum should be recollected and stored annually. Serum should be collected immediately after accidental injection or ingestion and at an appropriate interval thereafter. For those individuals exposed to long term lymphoid lines or their derivatives, anti-EB virus titers should be obtained on the collected sera.

\section{Laboratory Access}

Access to the cell culture area should be restricted to persons directly working with the cell lines, or by specific authorization by the principle investigator or director of the laboratory.

B. Personne1 Practices

1. Pipetting 
Mechanical pipetting aids rather than mouth pipetting should be used for all pipetting procedures.

2. Eating, Drinking and Smoking

Eating, drinking and smoking should not be allowed in the same areas where cell 1 ines are under study.

\section{Protective Clothing}

It is recognized that the criteria for protective clothing may vary according to the physical situation of the laboratory and the agents handled. Ideally, adequate protective clothing such as a fully fastened laboratory coat should be worn. This clothing should not be worn outside the work area once the work area has been entered.

C. Physical Control Practices (Recommended for all cell 1 ines, but required for long term lymphoid lines and their deriatives).

1. Ventilated Safety Cabinets or Hoods

Ventilated safety cabinets and hoods and other safety apparatus should be employed and should be tested at least annually to certify correct containment and operation. A list of specifications for satisfactory hoods and instructional materials may be obtained from the office of Biohazards, NCI.

2. Housekeeping

Appropriate housekeeping procedures which suppress the 
formation of aerosols should be used. Working surfaces should be wiped down with an appropriate disinfectant before and after work with each cell culture and at the end of the working day.

3. Decontamination and Disposal

Contaminated glassware and similar materials should be appropriately decontaminated or stored for decontamination before removal from the work area for recycling or disposal. Liquid wastes should be decontaminated either chemically or by heat, before being discharged to the community sanitary sewer system.

\section{Protection of Vacuum Lines}

Vacuum services, if used, should be protected with disposable absolute air filters and liquid traps. The effluent should be collected in liquid traps containing concentrated disinfectant.

\section{References}

Biohazards in Biological Research, ed. A. Hellman, M.N. Oxman and P. Pollack. Cold Spring Harbor Laboratory, New York (1973).

National Cancer Institute Specification: General Purpose Clean Air Biological Safety Cabinet. 
Biopsies are preferred to established cell cultures because they can be processed and stored in lower passage. When submitting a specimen to the Repository, the biopsy should be placed in a $25 \mathrm{~cm}^{2}$ tissue culture flask or screw top vial with culture medium containing 100 units/ml of penicillin and $100 \mathrm{mcg} / \mathrm{ml}$ of streptomycin. Tape the top or cap of the flask very securely to prevent leakage. Package the biopsy flask in a container so that it will not be broken in transit. Mark on the outside of the package that it should be kept at room temperature and not refrigerated, frozen or overheated.

Early passage cultures may be submitted when a biopsy cannot be obtained from the patient. The culture flask ( $25 \mathrm{~cm}^{2}$ preferably) should be filled to the top with culture medium and shipped as described above. Mail biopsy or culture the same day by air mail special delivery to:

\author{
Dr. Arthur E. Greene \\ Human Genetic Mutant Cel1 Repository \\ Institute for Medical Research \\ Copewood and Davis Streets \\ Camden, New Jersey 08103 \\ Phone 609-966-7377
}

Before a biopsy or cell culture can be processed for the 
Repository, documented proof of the diagnosis must be provided on a submission sheet which is available from the Institute for Medical Research, or may be photocopied by the submitter from pages 18-22. Without this information the culture cannot be coded into the information retrieval system or be of value to users of the Repository; and to conserve effort and expense the Repository staff are instructed not to process a specimen unless documentation of diagnosis is provided with the specimen. Submitters are therefore requested to fill in all applicable blanks on the submission sheets. Please provide a family genealogy if appropriate.

No biopsies or cell cultures submitted to the Human Mutant Cell Repository are to be obtained from a live fetus, defined by the presence of pulse, circulation and other vital signs. 
SUBMISSION SHEET

Please Complete Every Item that Applies.
TO BE FILLED IN BY IMR

Date Received

GM 非

Contamination ?

Failure

SPECIES: 1 HUMAN (Go to Item 1) 2 OTHER

Specify)

(Go to Item 8)

1. Initials:

2A. Date of Birth

$\frac{1}{\text { Mo. Day Year }}$ or Age:

2B. Gestational Age if Amniotic Fluid or Fetus:

3. Sex: 1 Male 2 Female 3 Ambiguous 4 Not Recorded

3 Oriental

2. Black

4. A. Race: 1 White

3. Sex: 1 Male 2 Female 3 Ambiguous 4 Not Recorded

Days Wks. Mos. Yrs.

(Circle One) Wks. (Circle One)

3. Sex: 1 Male 2 Female 3 Ambiguous 4 Not Recorded

B. Ethnic Background if Relevant to the Disorder:

(Especially Useful for Inborn Errors of Metabolism)

5. Clinical Phenotype:

1 Clinically Normal

3 No Information

2 Clinically Affected

6. Clinical Manifestations/Diagnosis: (Please List)
A.
B.
C.
D.
E.

7. Source(s) of Clinical Information: (Check One or More)
[1] Personal Examination
2 Hospital Records
3 Genetic Clinic Records
5 Autopsy Records
6 Private Physician
7 Other 4. Specialist's Report

(Specify)

8. Local Culture/Lab/Biopsy Identification Number:

9. Type of Sample: 1 Culture

\# Passages When Submitted

Date of Origin

Date Submitted

\begin{tabular}{cc}
$\frac{1}{\text { Mo. Day } / \text { Year }}$ \\
\hline Mo. Day Year
\end{tabular}

10. Tissue of Origin

\begin{tabular}{l}
\hline 1 Peripheral blood \\
2 Bone Marrow \\
3 Amniotic Fluid
\end{tabular}
2 Biopsy 3 Blood

Date obtained

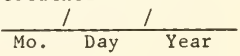

4 Skin

5 Other 
11. Culture Medium in which Submitted:

\begin{tabular}{|c|}
\hline McCoys \\
\hline Eagle-Hanks' \\
\hline Eagle-Earle \\
\hline Ham's F-12 \\
\hline Ham's F-10 \\
\hline
\end{tabular}

12. Addition of Following to Culture?

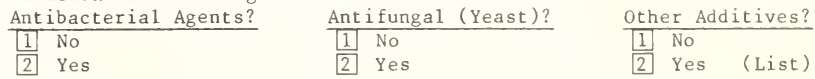

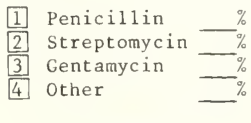

1 Fungizone

2 Mycostatin

3 Other

\section{(Specify)}

13. Special Instruction(s) on Handling or Freezing of Culture/Biopsy? 1] No 2 Yes (specify)

14. Have Chromosome Studies ever been Done on this Individual?

[1] Information Not Available (Go to Item 22)

2. No (Go to Item 22)

3 No, but Studies are Underway (Go to Item 22)

4. Yes

1 On Cells from this Culture

2. On Cells from Other Tissue/Samples

15. General Karyotype Results: 1 Normal

2. Abnorma 1

\begin{tabular}{l}
{$[1]$ Balanced } \\
{$[2]$ Unbalanced } \\
\hline 3 Not Certain
\end{tabular}

16. Sex Chromosomal Complement: (Check One or More)

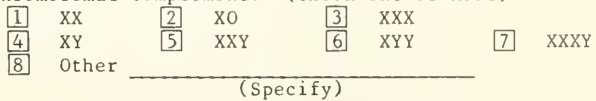

17. Autosomal Mosaicism?

1 Detected (If so, \# and \% Sub Lines: 
18. Breakage/Somatic Rearrangements?

[1] Data Not Available

Data Available



[1] Breaks Observed

[2] Somatic Rearrangements Observed

3 Neither Observed

19. Current International Nomenclature:

20. The Above Karyotype is Based on 1 Banded or 2 Unbanded Technique (s).

21. If Banded, what Staining Method(s) was Used:

22. Have Biochemical Studies been Done on this Individual

1 No (Go to Item 29)

2. Yes

1 On Cells from this Culture (Go to Item 23)

2 On Other Cultures or Tissues from Same Patient (Go to Item 28)

23. Specific Defect Detected or Investigated:

24. Assay Method Used:

25. Assay Level in this Cell Culture:

26. Assay Level in Normal Control Cell Cultures

27. Conclusion Based on Biochemical Assay:

1 Normal 2 Abnormal 3 Inconclusive

1 Consistent with Heterozygosity

2 Consistent with Homozygosity

3 Genotype Uncertain

4. Not Applicable 
28. Significant Laboratory Data on Other Cell Cultures or Tissues from this Individual:

\begin{tabular}{|c|c|c|c|}
\hline Tissue & Assay & Level & $\begin{array}{l}\text { Conclusion } \\
\text { (See Item 27) }\end{array}$ \\
\hline & & & \\
\hline & & & \\
\hline & & & \\
\hline & & & \\
\hline
\end{tabular}

29. Is Pedigree Available? [1 No [2 Yes

\begin{tabular}{l|l|l|l|l|l} 
30. & $\begin{array}{l}\text { Relative } \\
\text { Studies } \\
\text { Done? }\end{array}$ & $\begin{array}{l}\text { Biochem. } \\
\text { Studies } \\
\text { Done? }\end{array}$ & $\begin{array}{c}\text { Clinical Lab } \\
\text { Studies } \\
\text { Done? }\end{array}$ & $\begin{array}{c}\text { Cultures } \\
\text { Available? }\end{array}$ & $\begin{array}{c}\text { Banked in } \\
\text { Camden? }\end{array}$ \\
\hline Father & & & & & \\
\hline Mother & & & & & \\
\hline $\begin{array}{l}\text { Siblings } \\
\text { Offspring } \\
\text { Other }\end{array}$ & & & & & \\
\hline
\end{tabular}

31. Has this Patient/Family been Reported in Literature?

[1] No 2 Yes

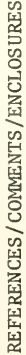

32. Has a Sample from this Patient been Previously Stored in Camden?

1 No 2 Yes, GM 非

33. Any Additional Comments/Observations/References/Lab Studies on Culture, Patient, Family Etc.?

Enclosures: [1] Pedigree [2 Clinical History/Description of Patient and/or Family

3 Karyotype 4 Laboratory Data on Patient/Family

5 Reprint of Reference 6 Other

(Specify) 
To encourage storage of unusual cell cultures in the Repository, provision has been made for delayed release to other investigators if the contributor so desires. Please check your preference: a) release culture to anyone requesting it____ b) release only to contributor during the first year_. At the conclusion of 1 year the cell culture will be 1 isted in the next printing of the catalog and made available to other investigators unless additional time is specifically requested.

I hereby grant permission for these cells to be stored in a bank of genetic mutant cell cultures and the progeny cells distributed to qualified investigators. Appropriate consent was obtained from the patient from whom the cells were originally obtained, or can be reasonably inferred, for use of these cells for diagnosis, research, teaching or therapy.

No biopsies or cell cultures submitted to the Human Mutant Cell Repository are to be obtained from a live fetus, defined by the presence of pulse, circulation and other vital signs.

Date Submitter

(Signature)

Address

Telephone Number

Mail completed form with, or preferably preceeding shipment of cell cultures, to: Dr. Arthur Greene, Institute for Medical Research, Copewood and Davis Streets, Camden, New Jersey 08103.

Phone: 609-966-7377. 
EXPLANATION OF THE CODE INTERPRETING RECORDED

DATA IN THE COLUMNS OF THE CATALOG

\section{COLUMN}

GM 非: The GM number of the cell culture, refers to the number assigned to the culture when it was received at the Human Genetic Mutant Cell Repository. Fibroblast cultures are all originated from skin unless noted in the Remarks column.

Lymphocyte cultures are all established from peripheral blood. McKusick's number is inserted following the name of each disease.*

Passage 非: The number of serial in vitro transfers of the cell culture as stored in liquid nitrogen.

Culture Medium: For code see appendix A, page 131.

Submitter Code: A number which identifies the investigator who submitted the biopsy or culture to the Repository. For code see appendix B, page 133 .

Age: Age of the donor is expressed in years, or when appropriate in months (mo.), weeks (wk.) or days (da.). F indicates fetus.

Sex: $M$ or $F$

Race: W-Caucasian; B-black; O-Oriental; I-Indian (India); P-Puerto Rican. Space left empty if race unknown.

*McKusick, Victor. Mendelian Inheritance in Man 4th Edition. John's Hopkins Press, Baltimore, London. 1975. 
Normal gene

$\begin{array}{ll}\text { y } & \text { Affected gene } \\ \text { ? } & \text { Hemizygous for } \mathrm{X} \text {-1inked trait } \\ & \text { genetic status not determined } \\ & \text { Carrier for trait as determined } \\ & \text { by pedigree or clinical diagnosis }\end{array}$

The McKusick* number immediately following the name of the disease will indicate the dominant, recessive, or X-linked nature of the disease. The first digit is one for a dominant disease (e.g. Huntington Chorea - 14310), two for a recessive disease (e.g. Tay-Sachs Disease - 27280), and three for an X-linked trait (e.g. Lesch Nyhan Syndrome - 30800).

Verified: $B$ if the defect was verified on the cell culture before freezing, A if verified after recovery from liquid nitrogen. Space left blank if verified on another cell culture or tissues from the same patient or relative, if not verified at all, or if verification is not yet possible because defect is unknown or not yet expressed in culture.

Paris Nomenclature: As described (Paris Conference 1971) and Supplement (1975): Standardization in Human Cytogenetics. Birth Defects: Original Article Series, VIII:7, 1972. The National Foundation, New York.

*McKusick, Victor. Mendelian Inheritance in Man 4th Edition. John's Hopkins Press, Baltimore, London. 1975. 
Balanced, Unbalanced: Balanced (B) or Unbalanced (U) karyotype

Remarks: Any pertinent information not included in preceding columns.

*after GM 非: Means a description of this cell culture has been published in Cytogenetics and Cell Genetics. Reference numbers appearing in parentheses at the bottom of the page refer to these publications 1 isted in Appendix C, pages 153-160.

Aging Cell Repository: Cell cultures 1 isted under this heading are of particular interest to investigators interested in studies on aging. Some cultures originally deposited in the GM Repository are also of interest to the Aging Repository. For convenience these cell cultures are 1 isted in both the GM and the Aging (AG) Repository. Many new cell cultures are now being added to the Aging Repository and receive an AG \#. Double listings will be made when appropriate. Requests for these cells may be addressed to the Director of the Aging Repository:

\author{
Dr. Warren W. Nichols \\ Institute for Medical Research \\ Copewood Street \\ Camden, New Jersey 08103 \\ Telephone 609-966-7377
}

Procedures and charges are the same as for the Genetic Mutant Cell Repository. The Aging Repository is supported by the National Institute of Aging. 


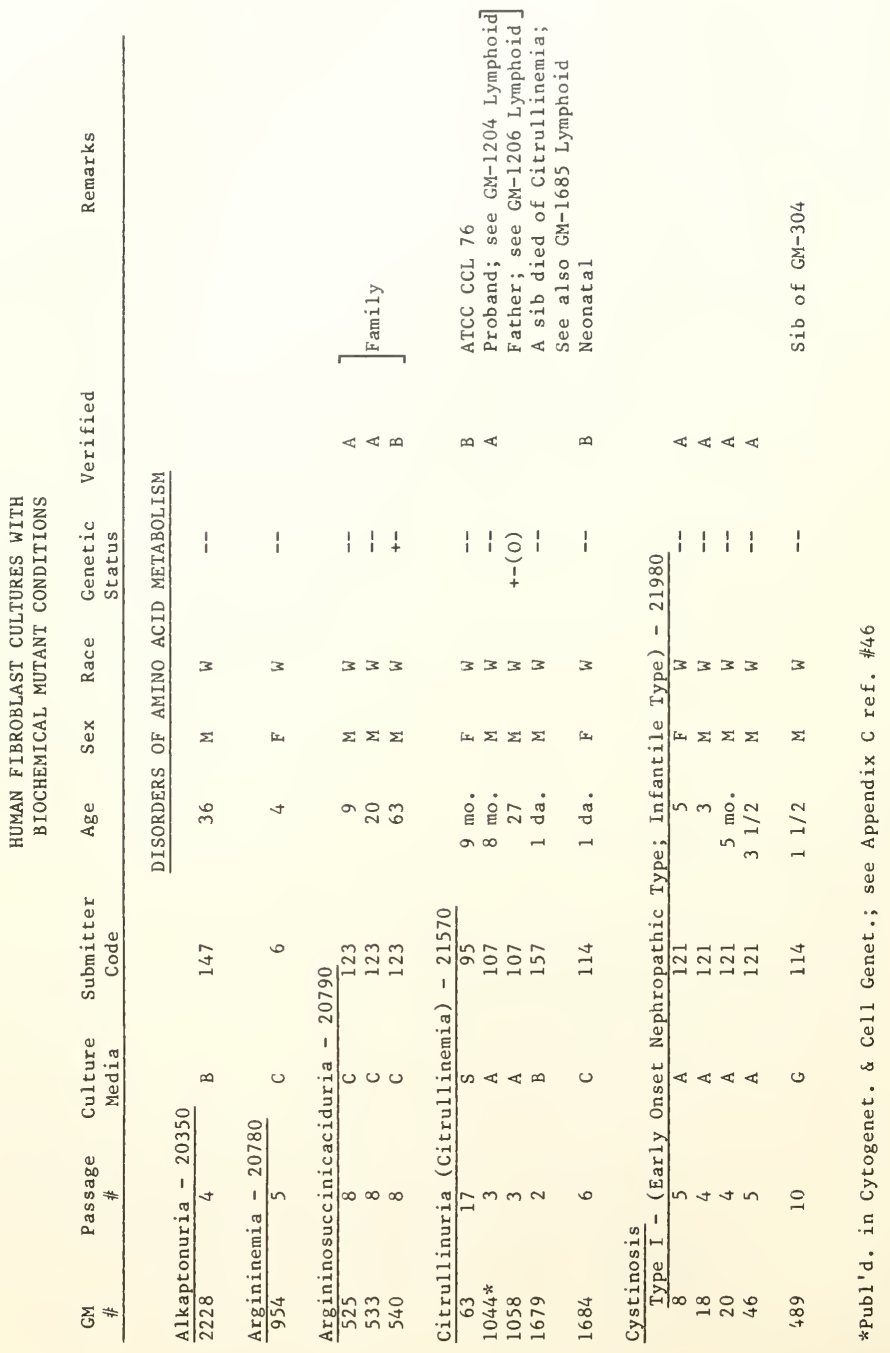




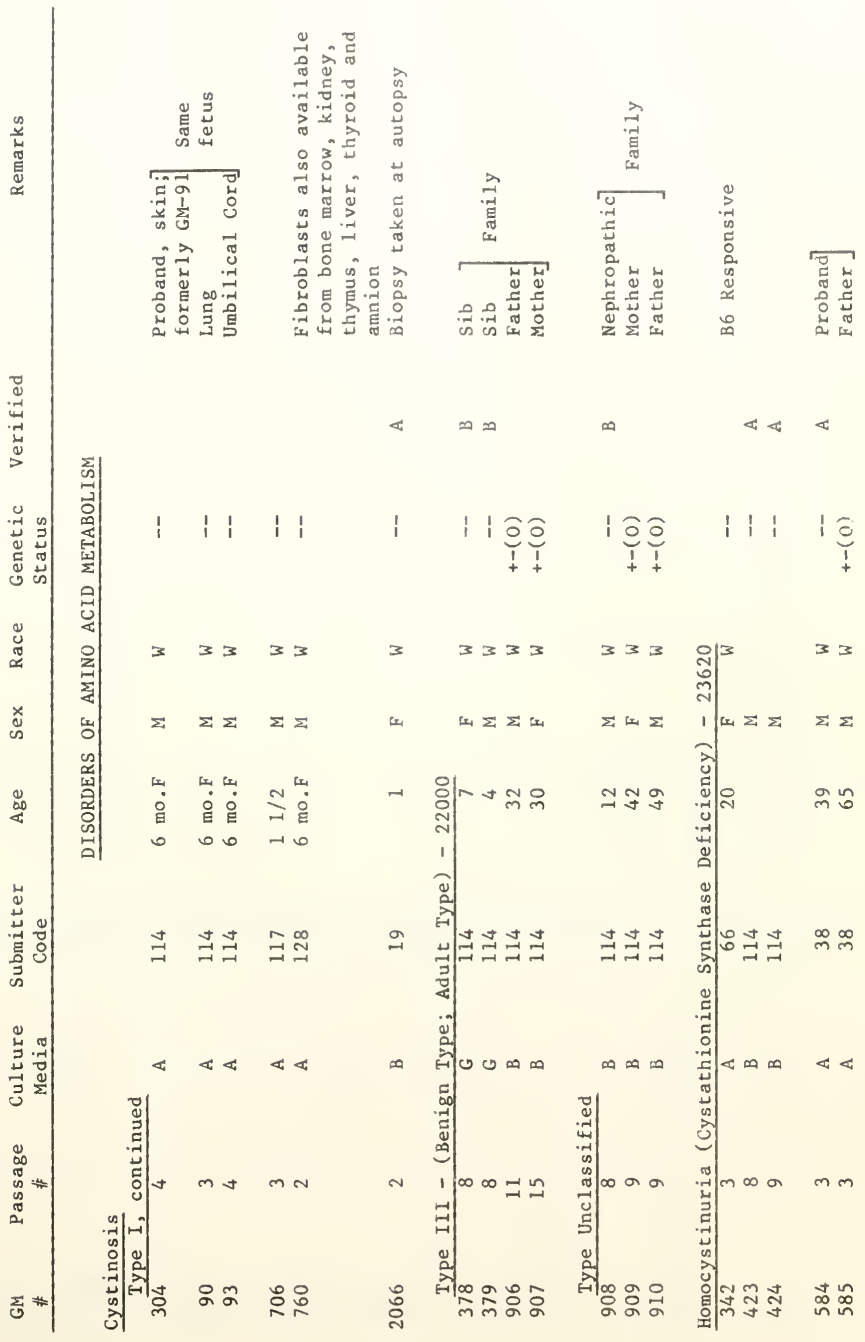




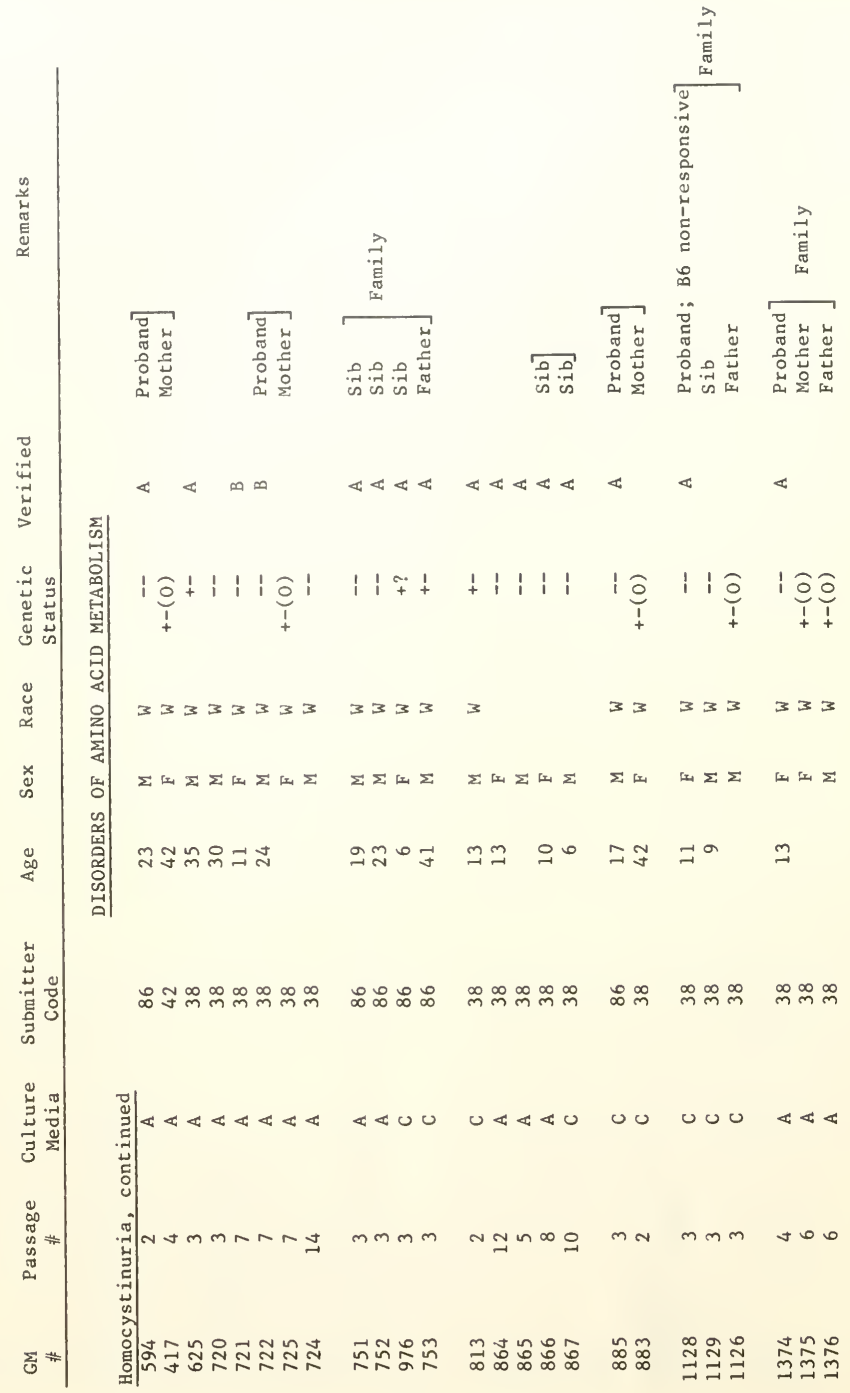


10 


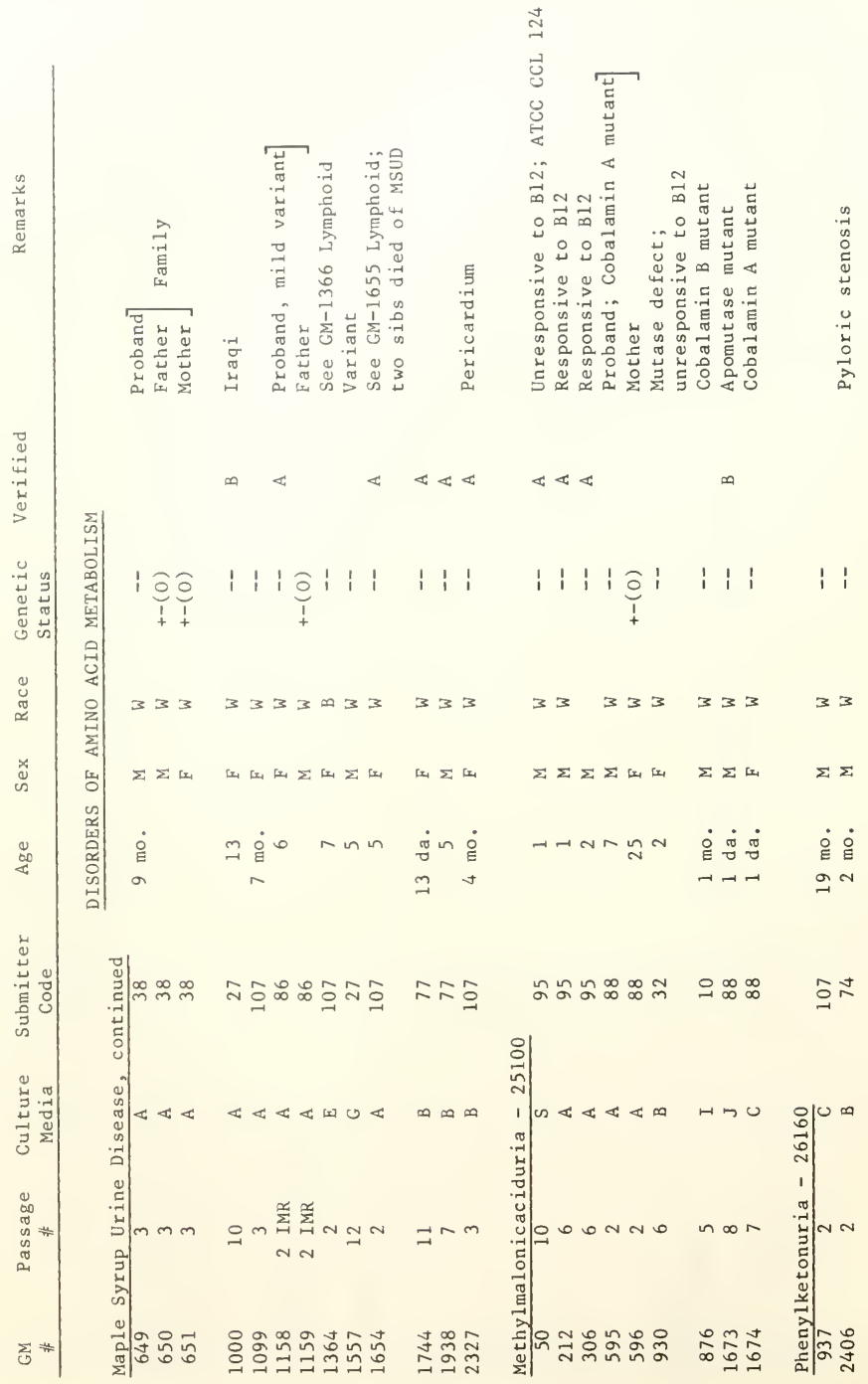



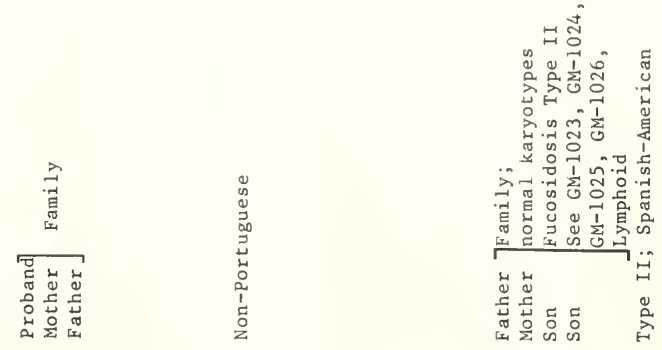

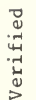

0
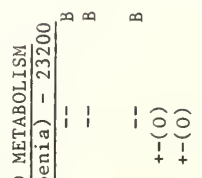

产

$\stackrel{\varpi}{ \pm}$

(3)

잉

爻

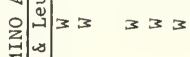

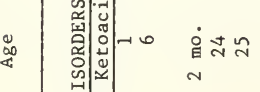

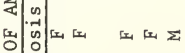

का.

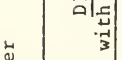

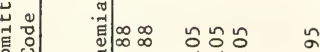

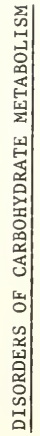

$\infty \infty$

4

$\infty$

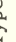

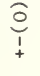

อิ 1 i i

9
1
+
+

333

3333

$\underset{\frac{\pi}{\pi}}{\stackrel{4}{\pi}}$

हु

()

\%

त)

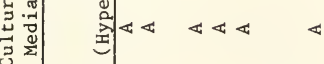

(4) 红 $\Sigma$ 厌

[4

$\sum \sum \sum \sum$

$\Sigma 0$

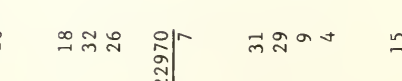

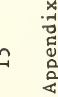

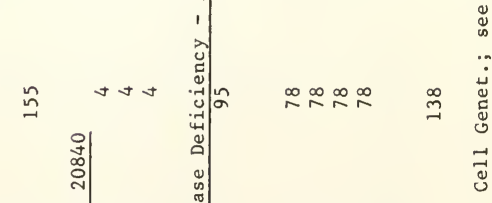

$\infty$
in
in
क
0

1

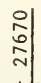

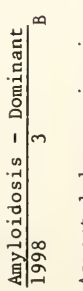

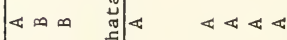

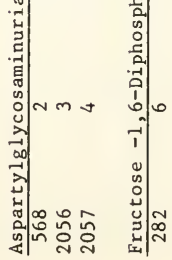

잉

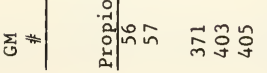
究 


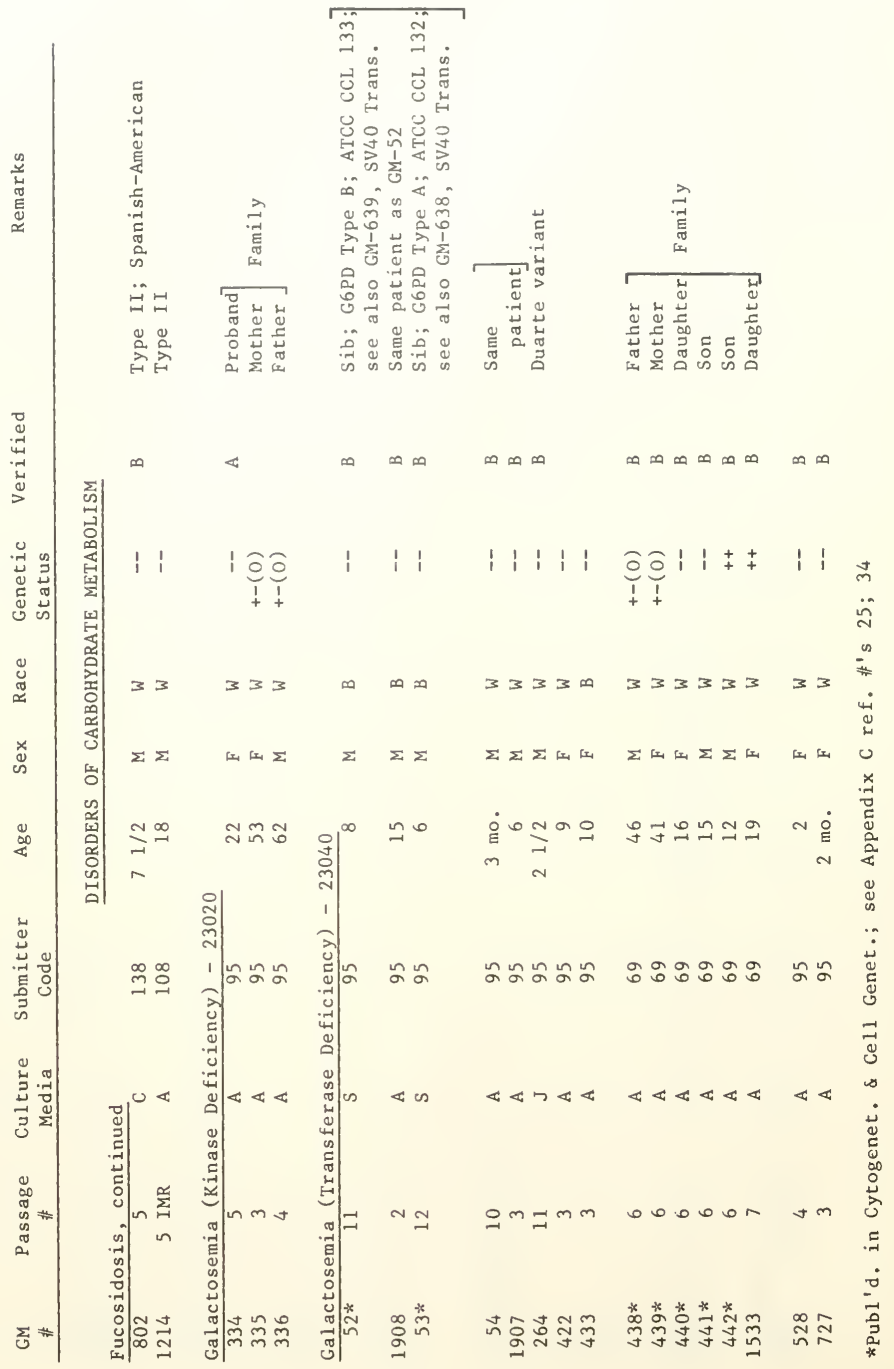




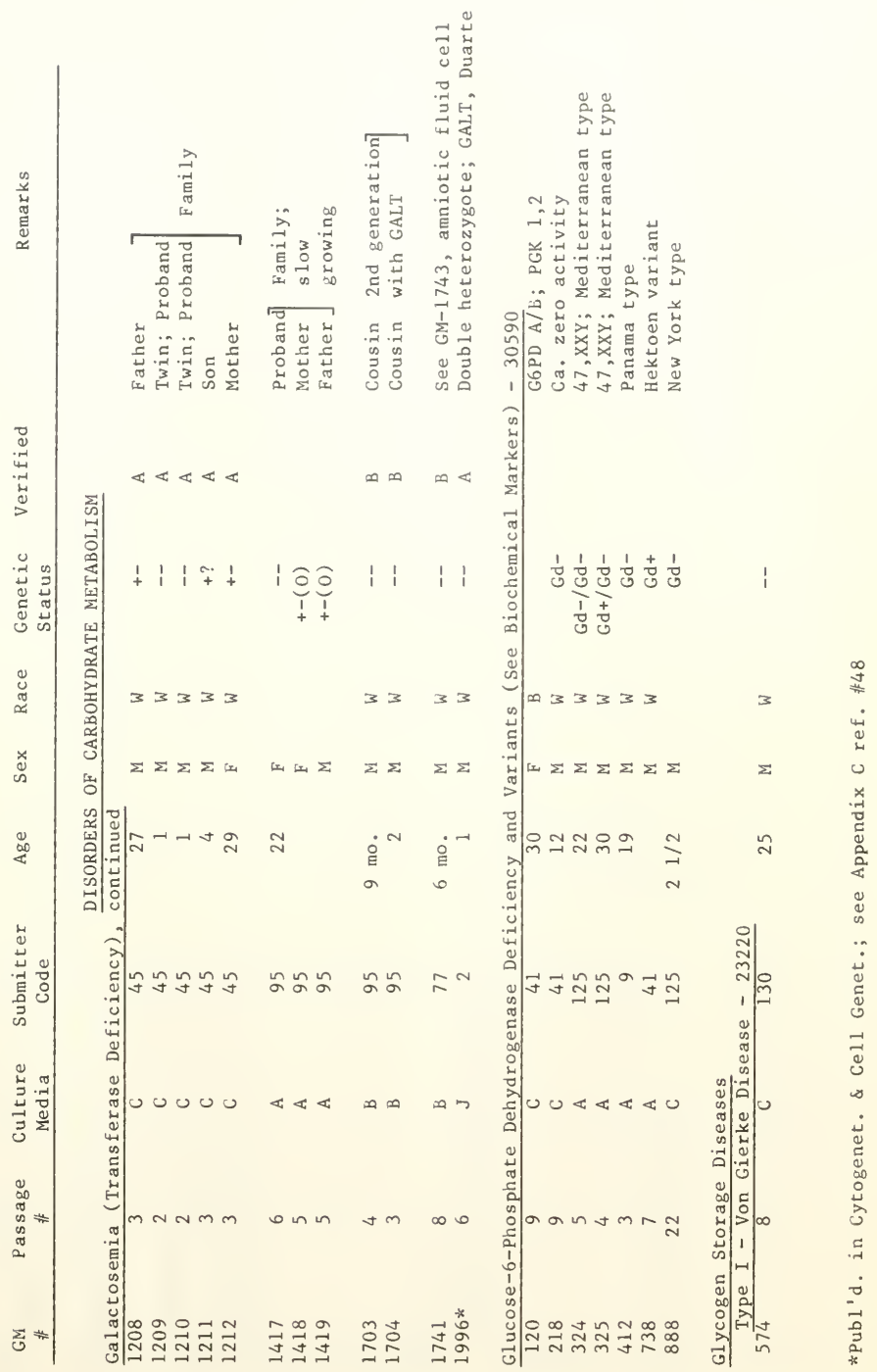




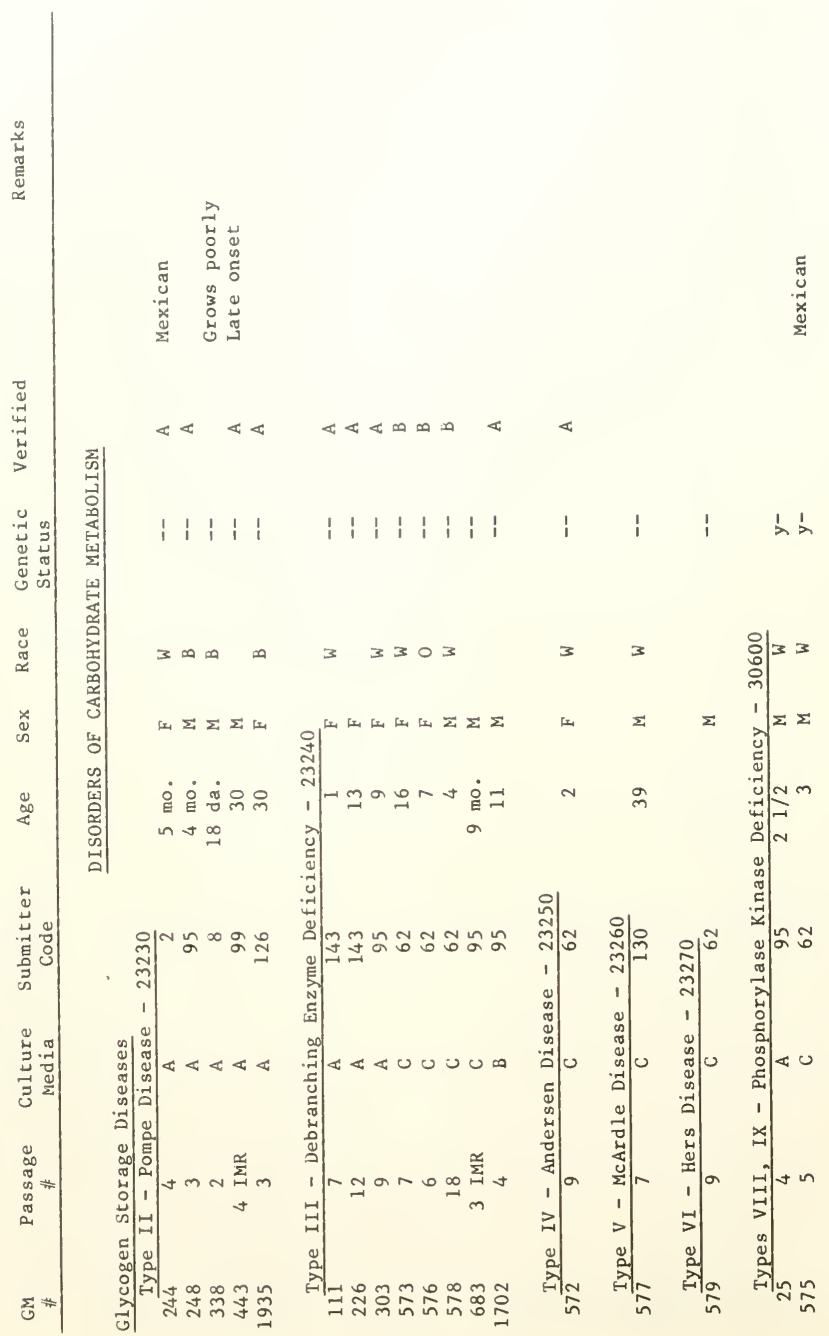




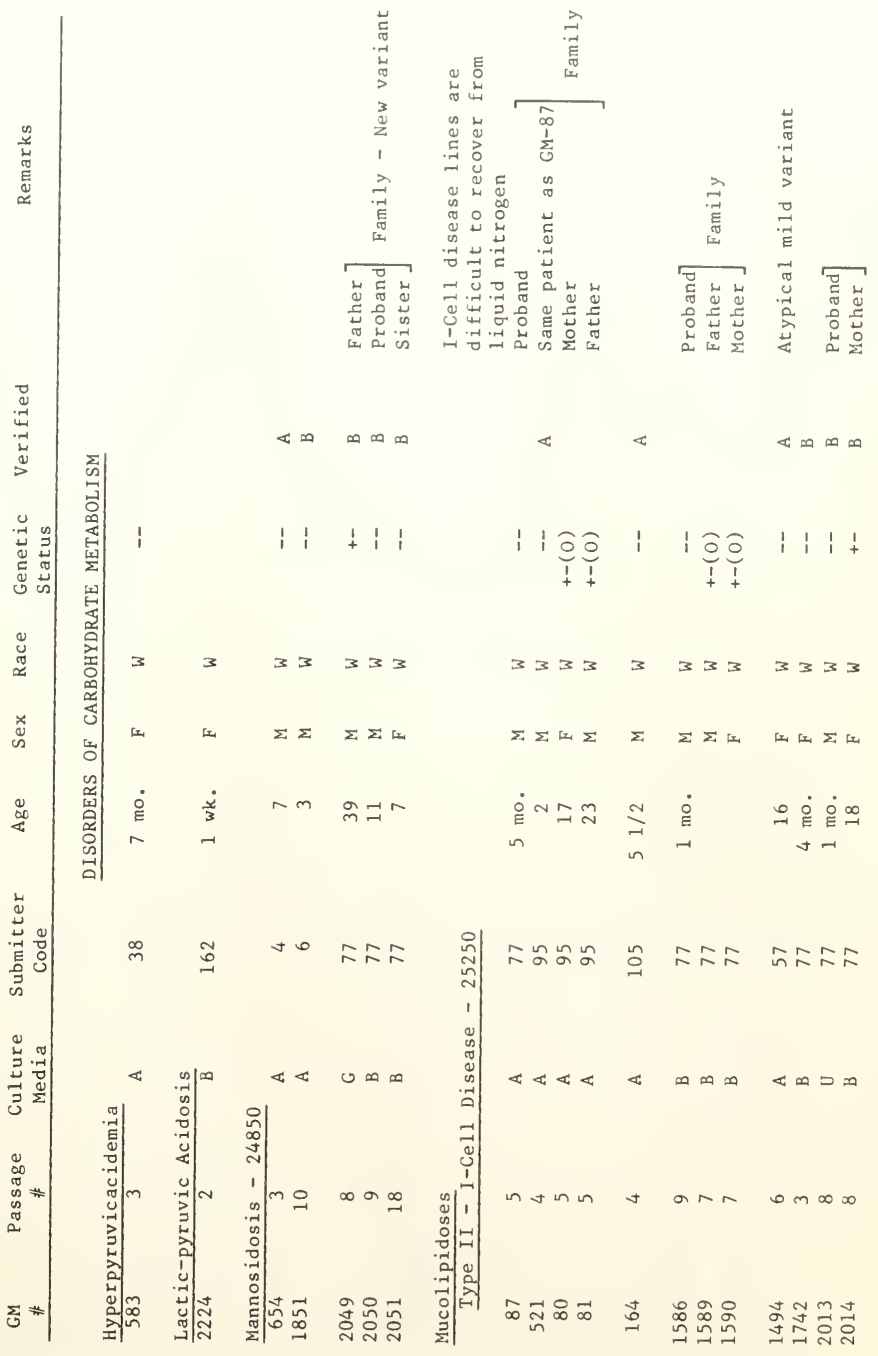




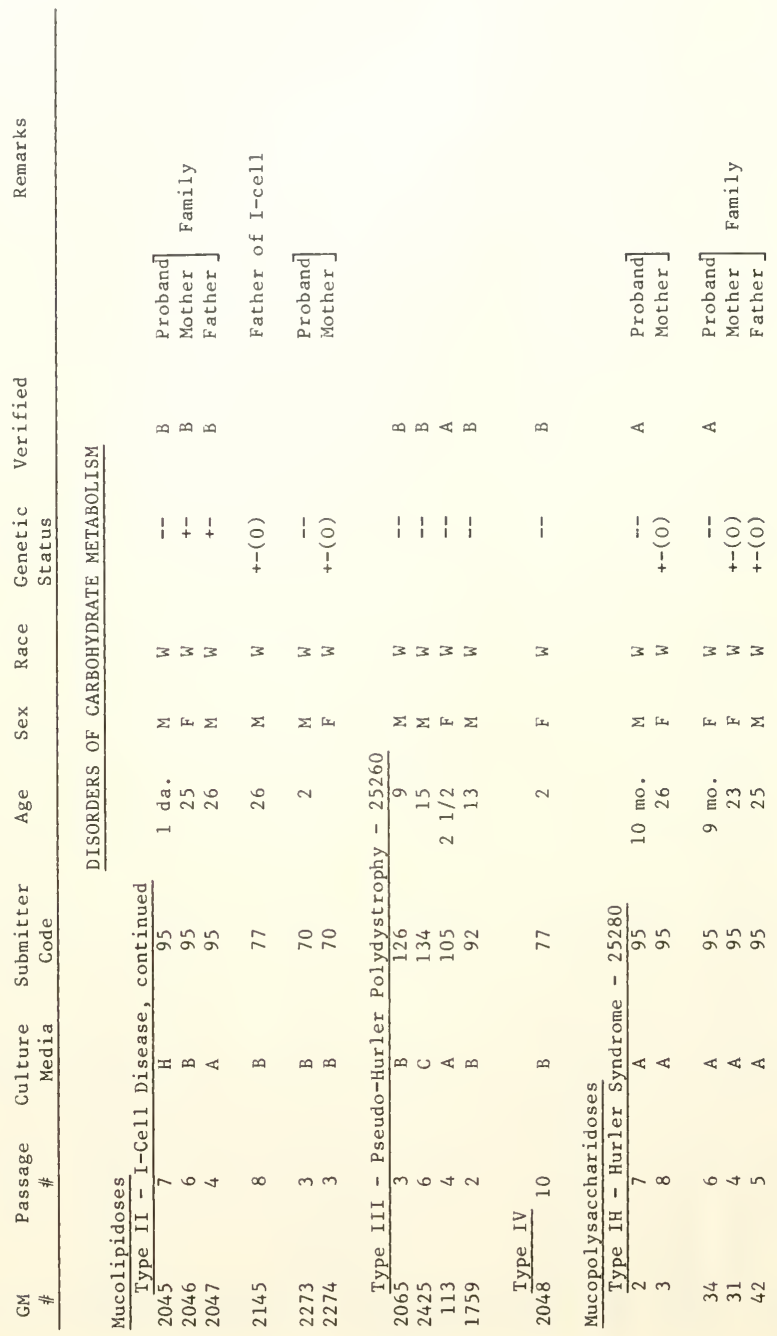




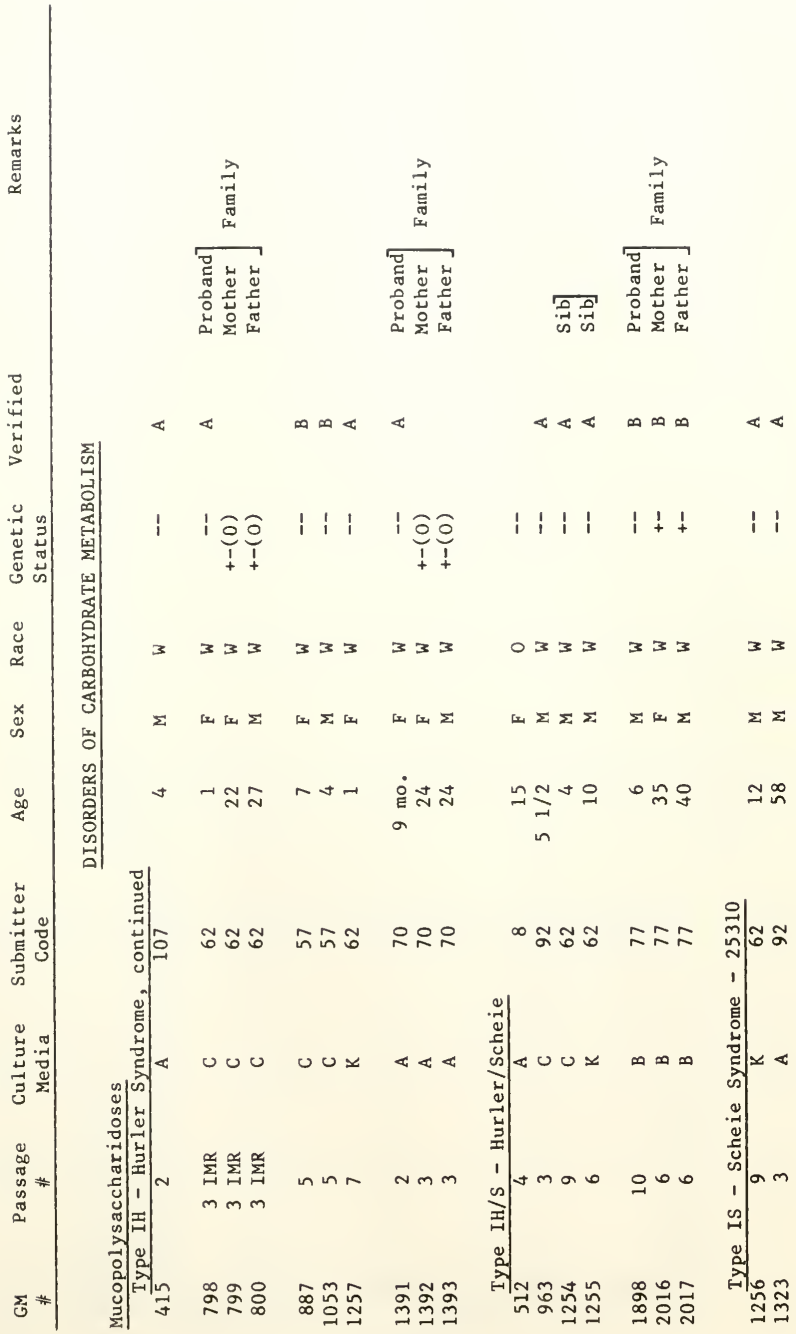




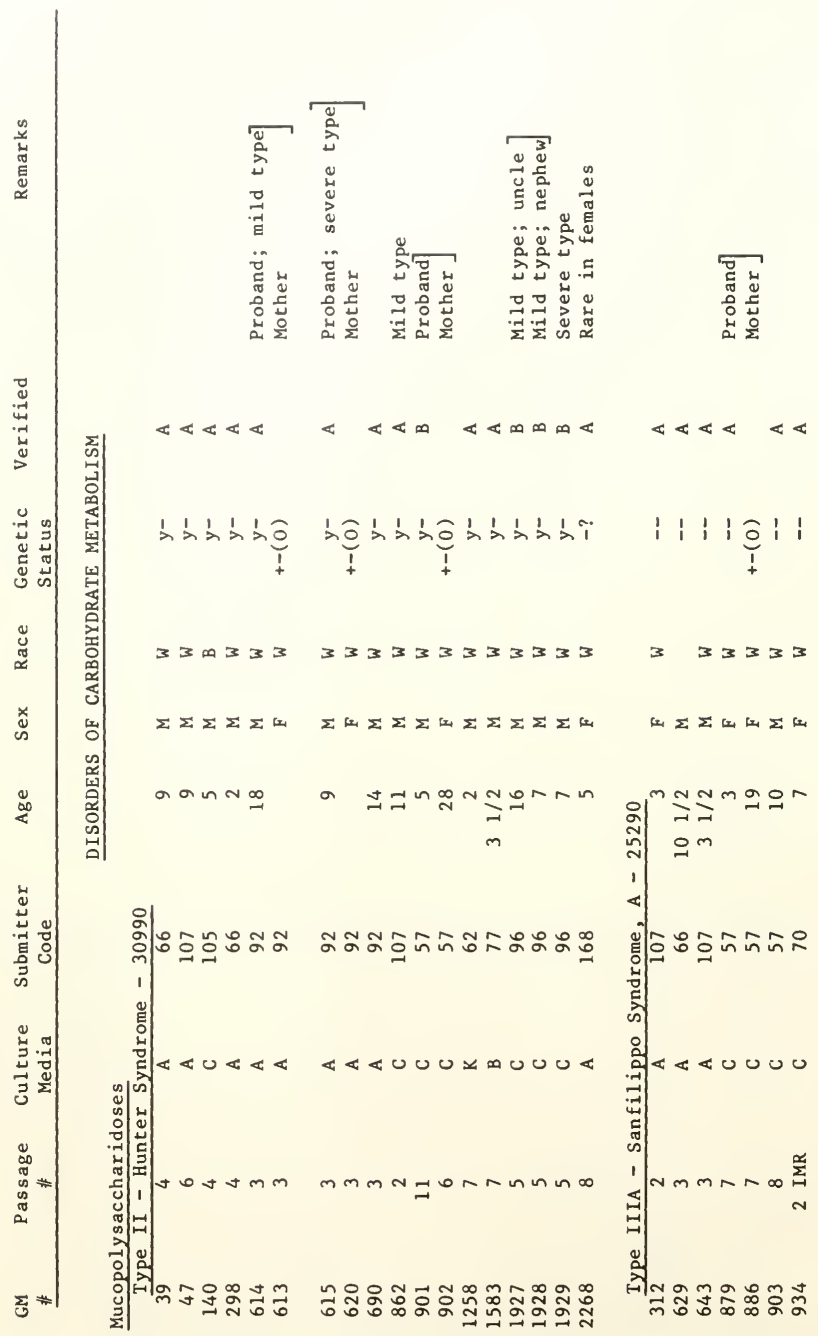




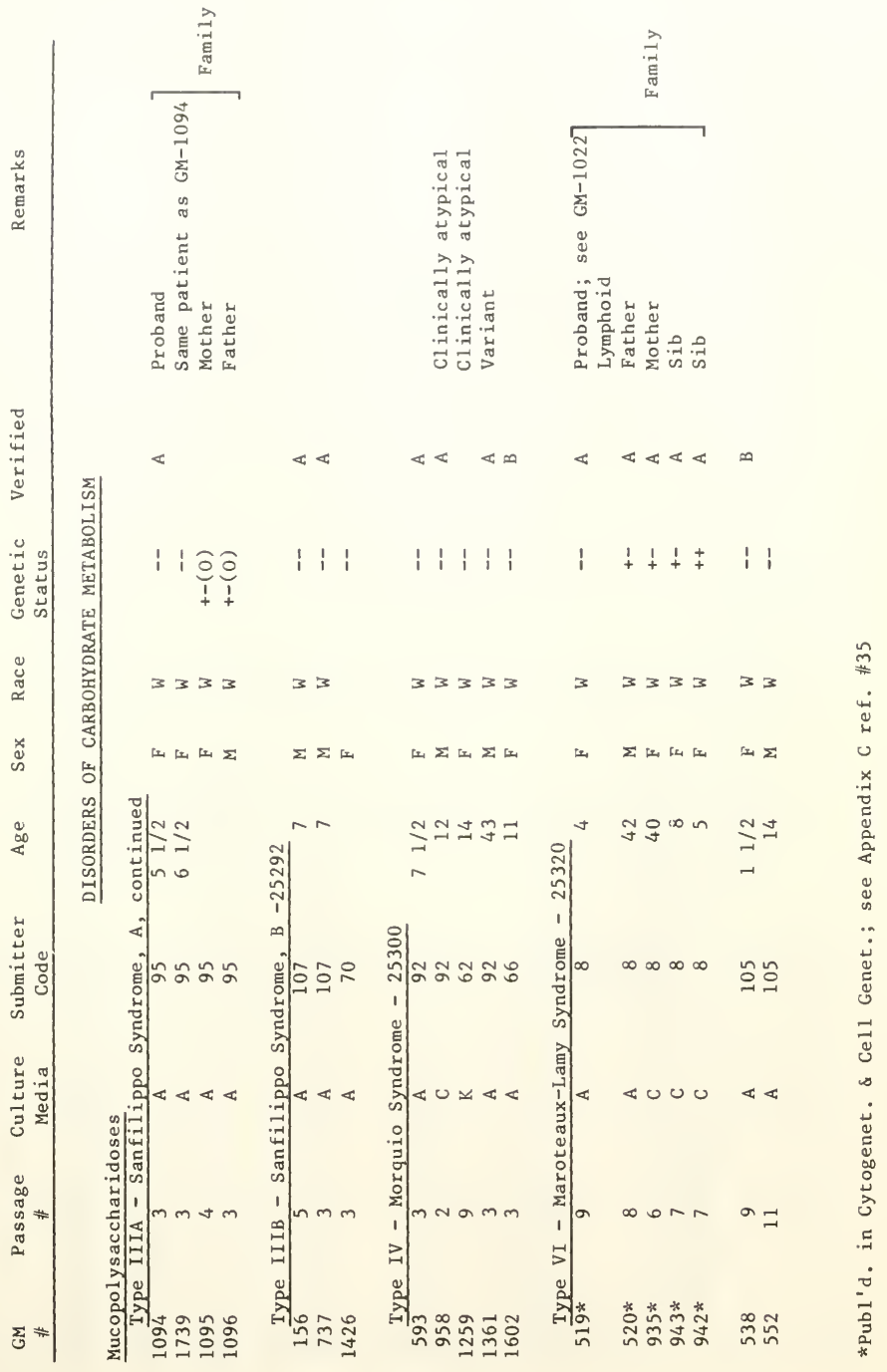




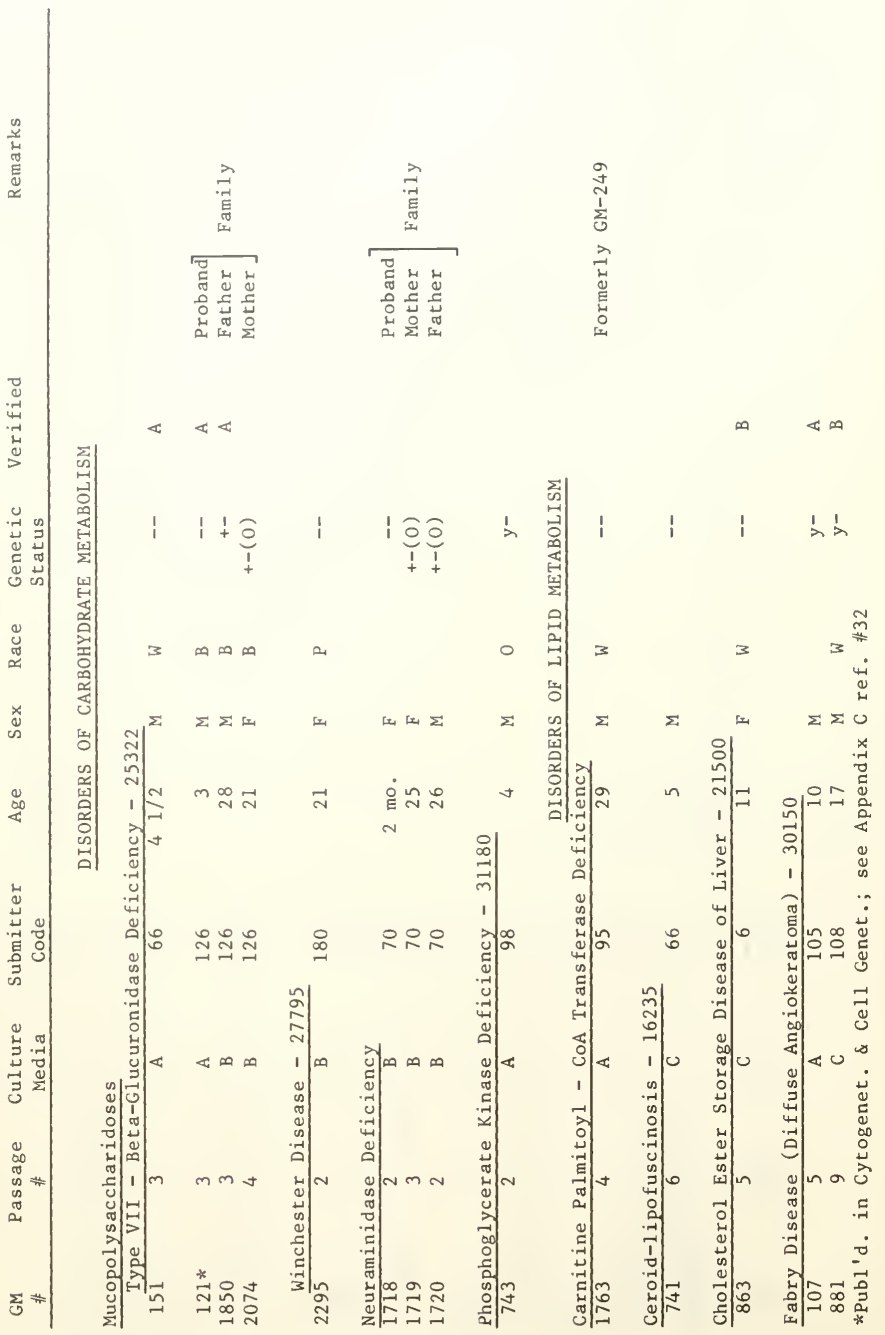




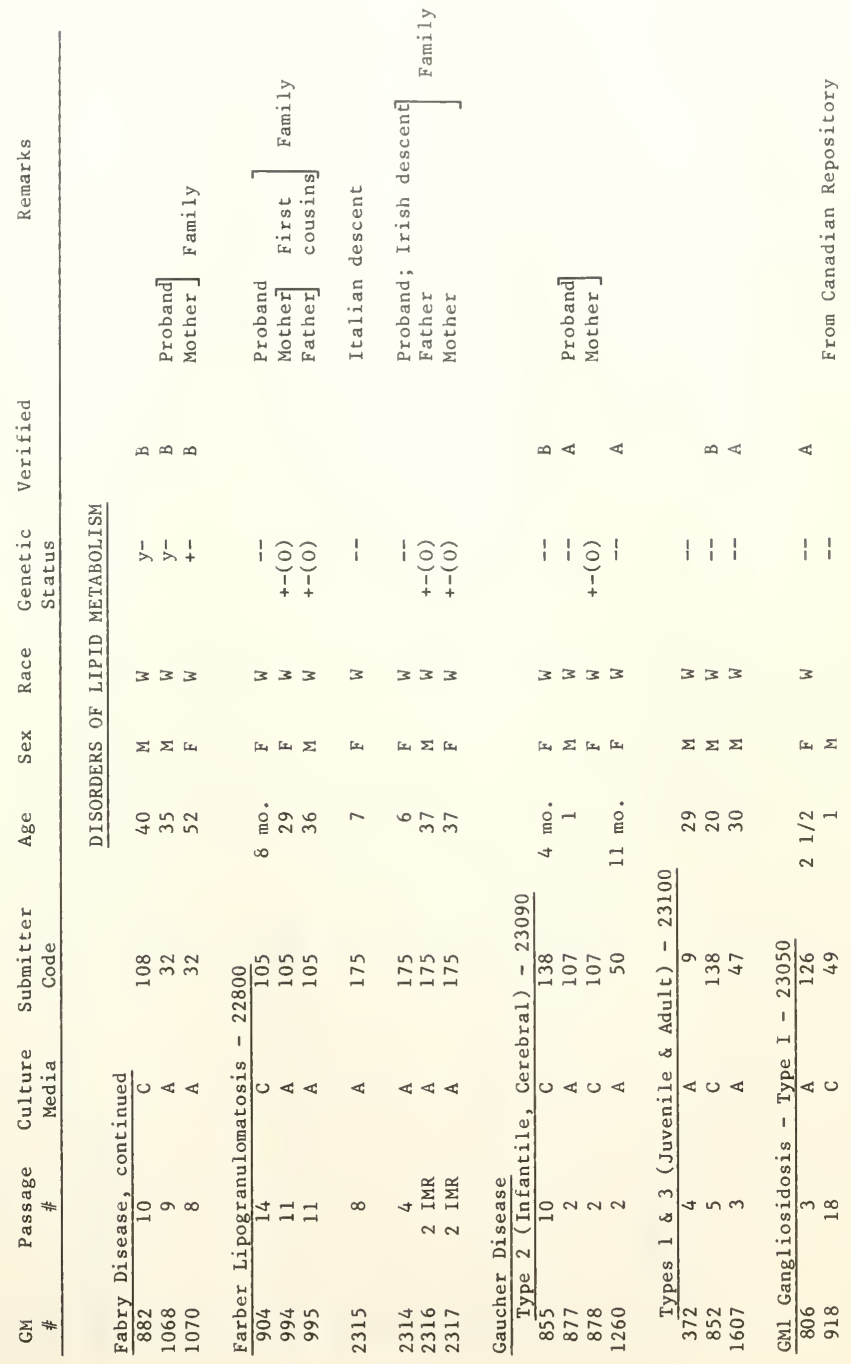




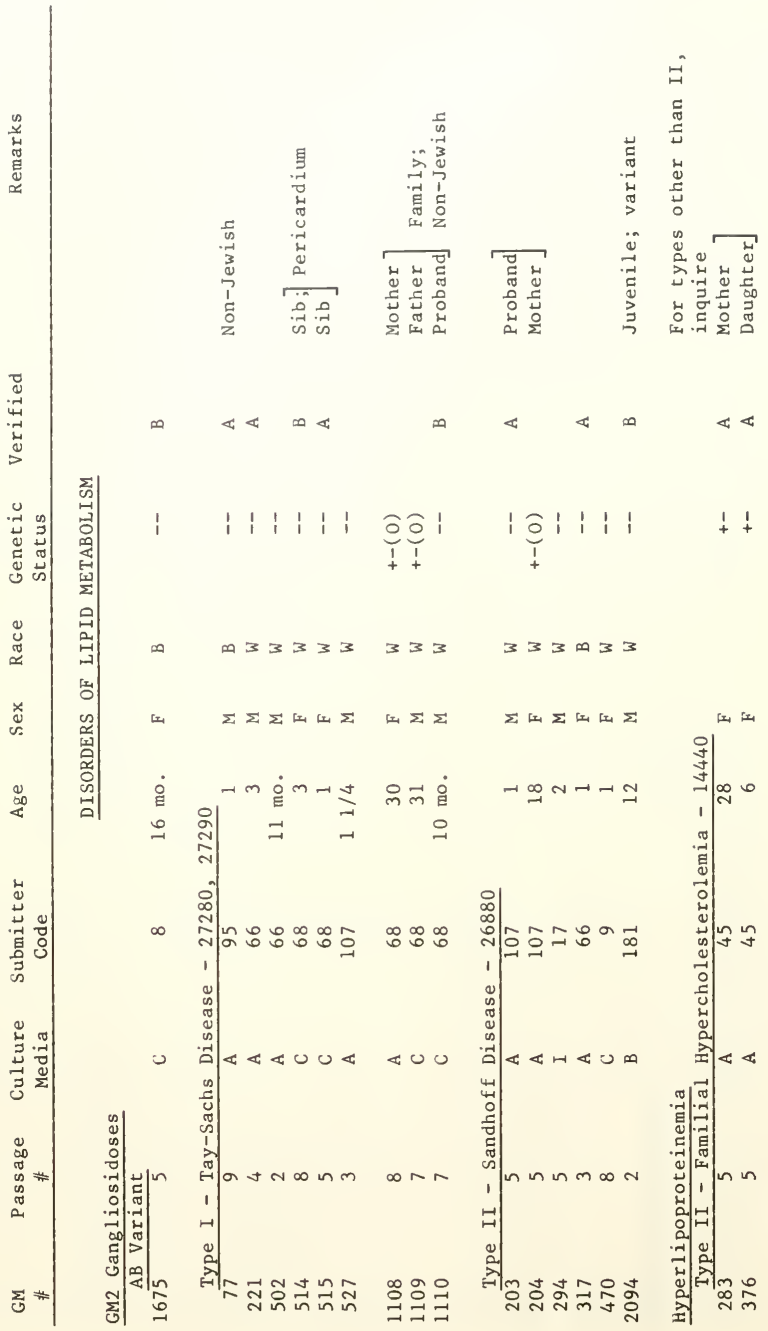




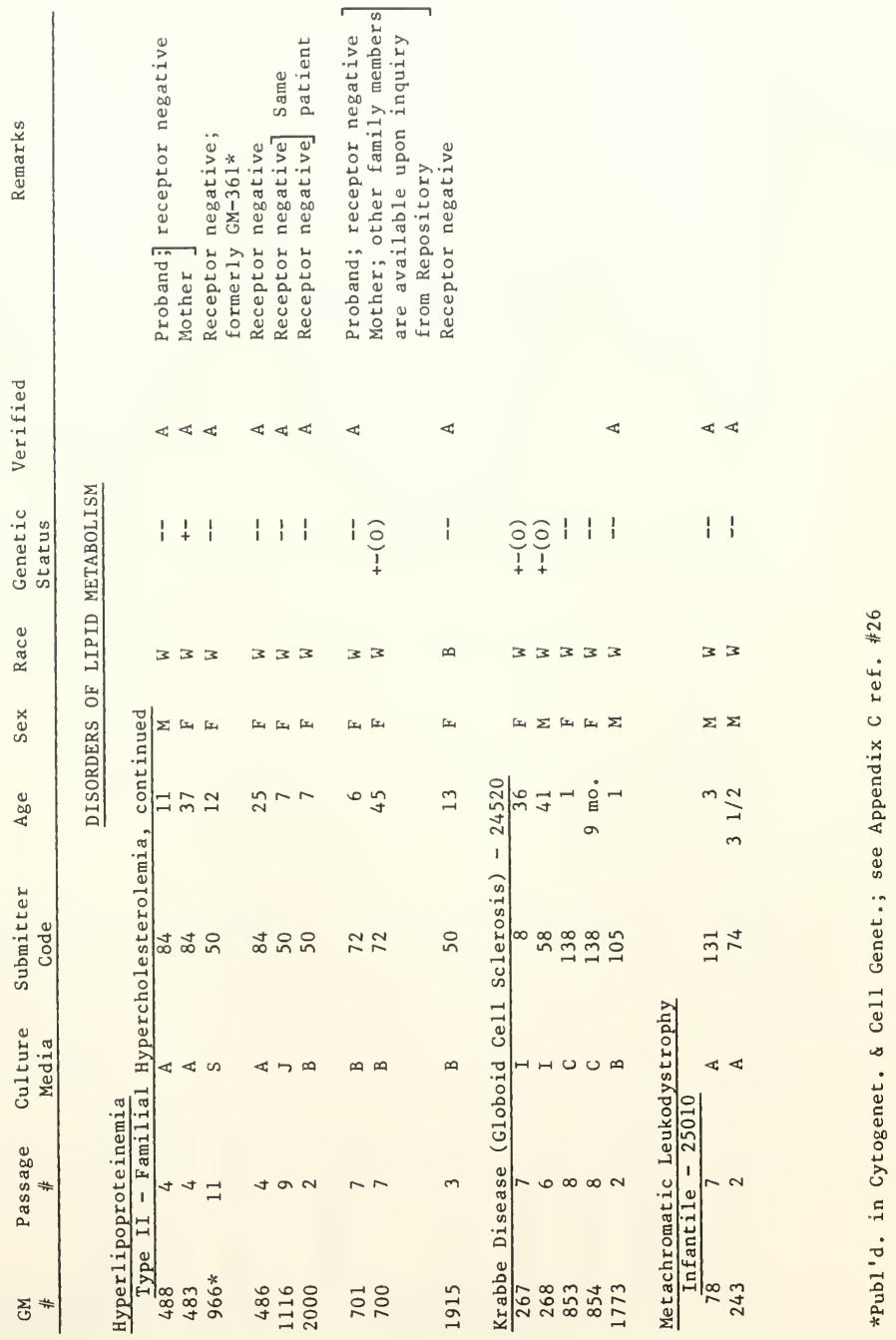




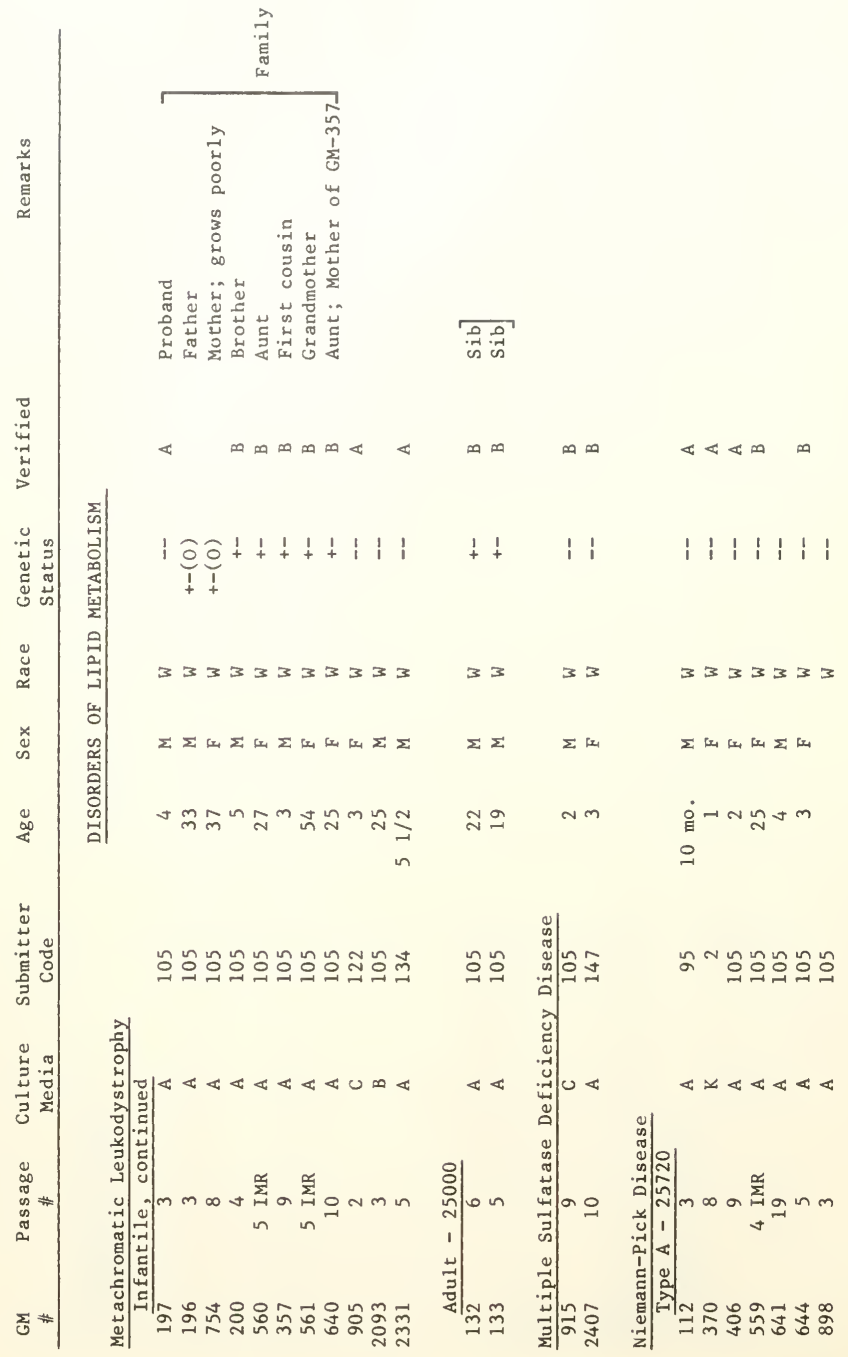




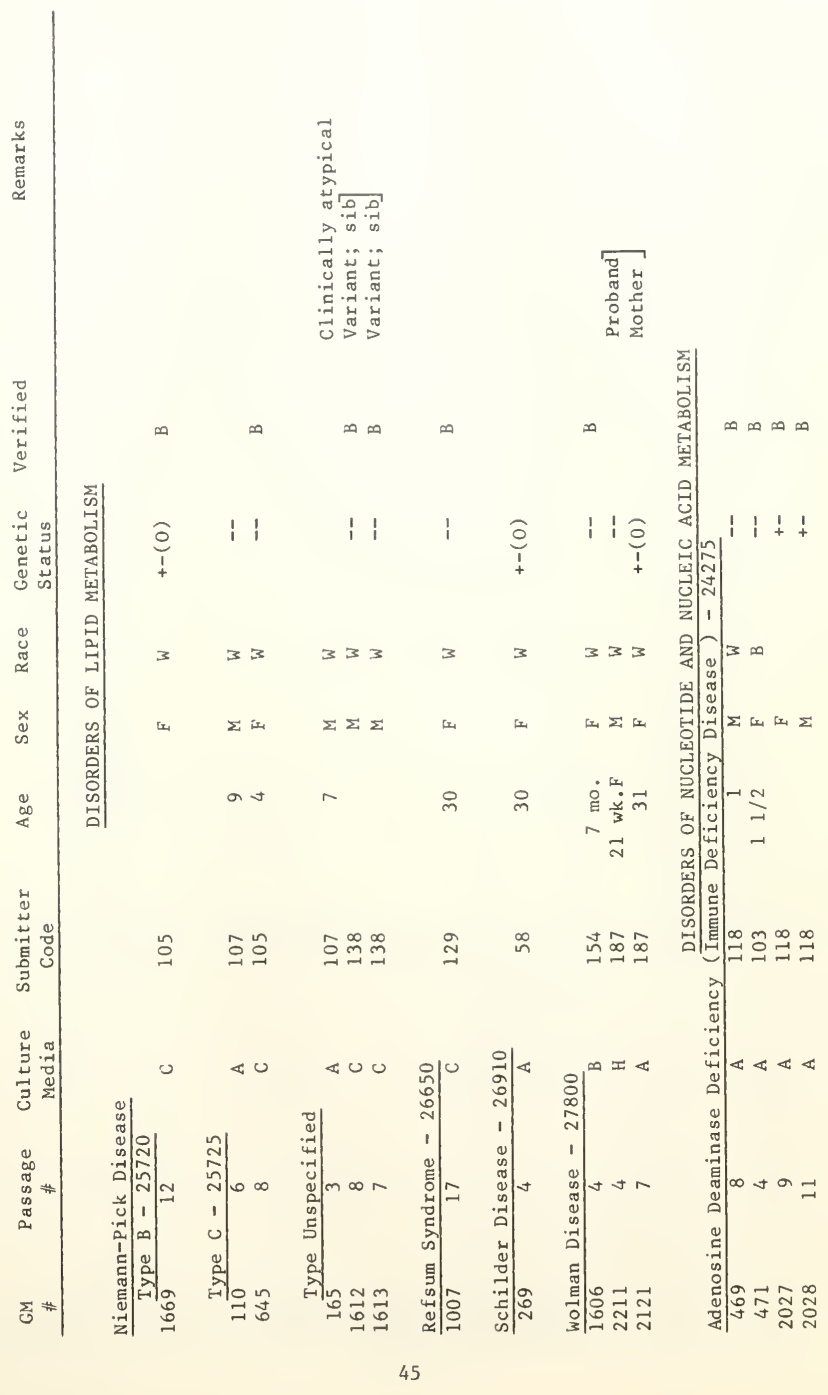




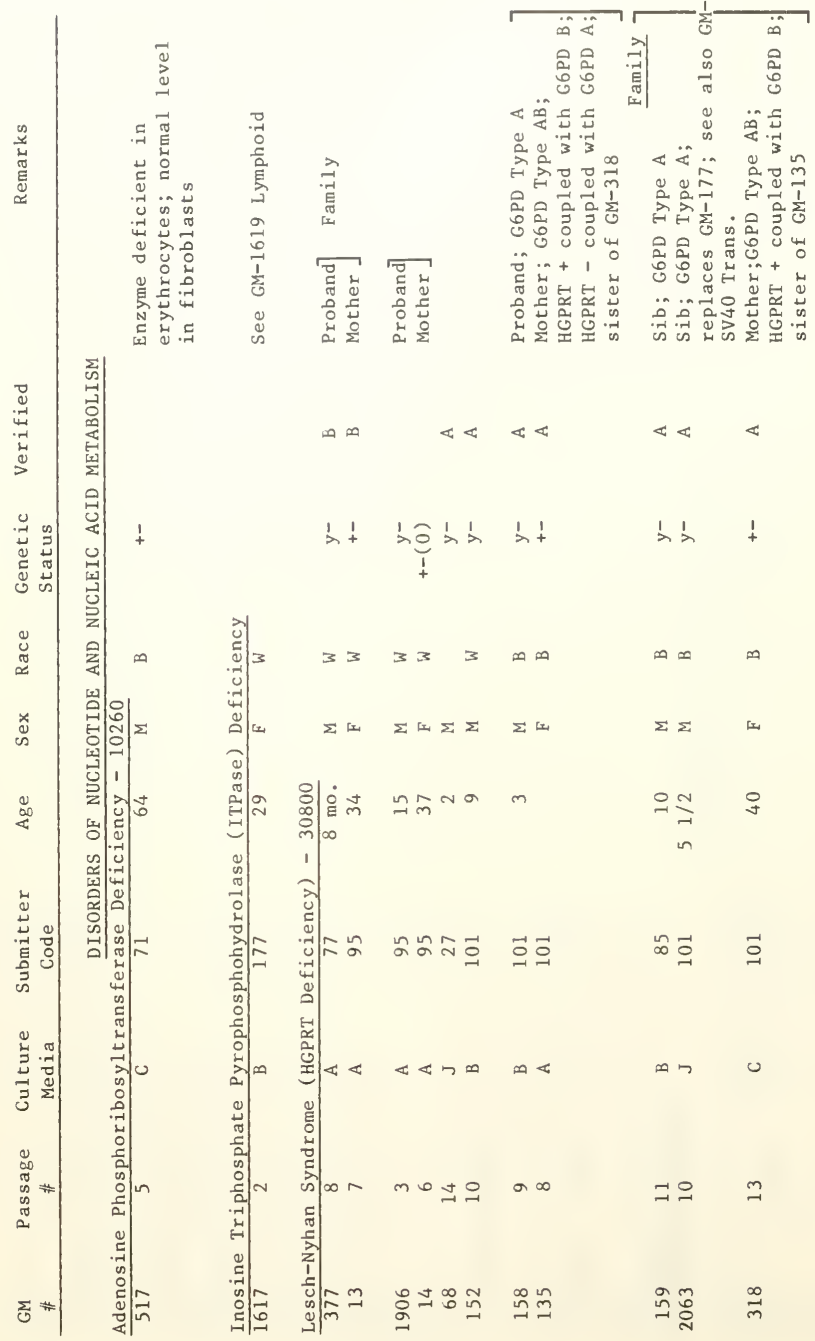




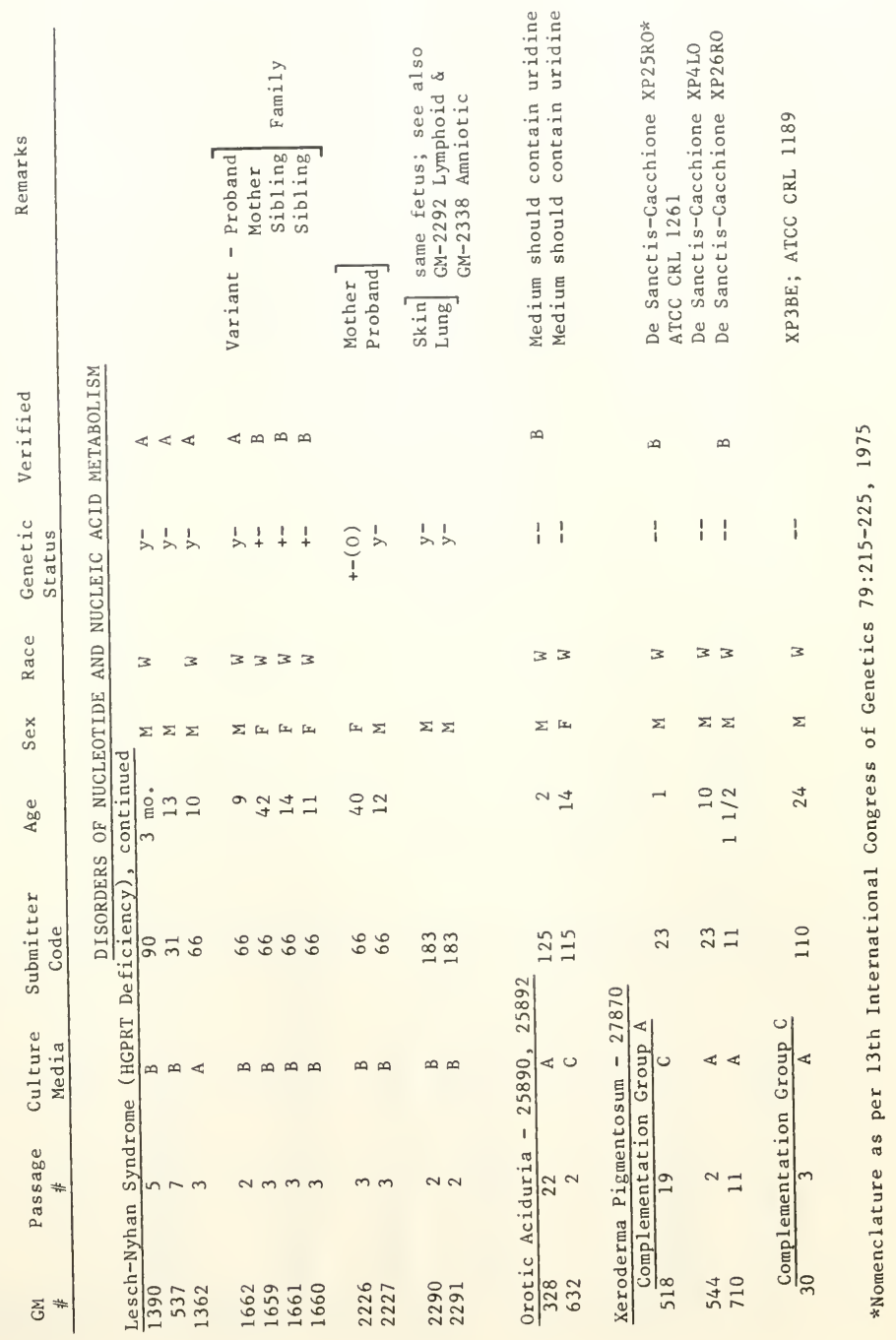




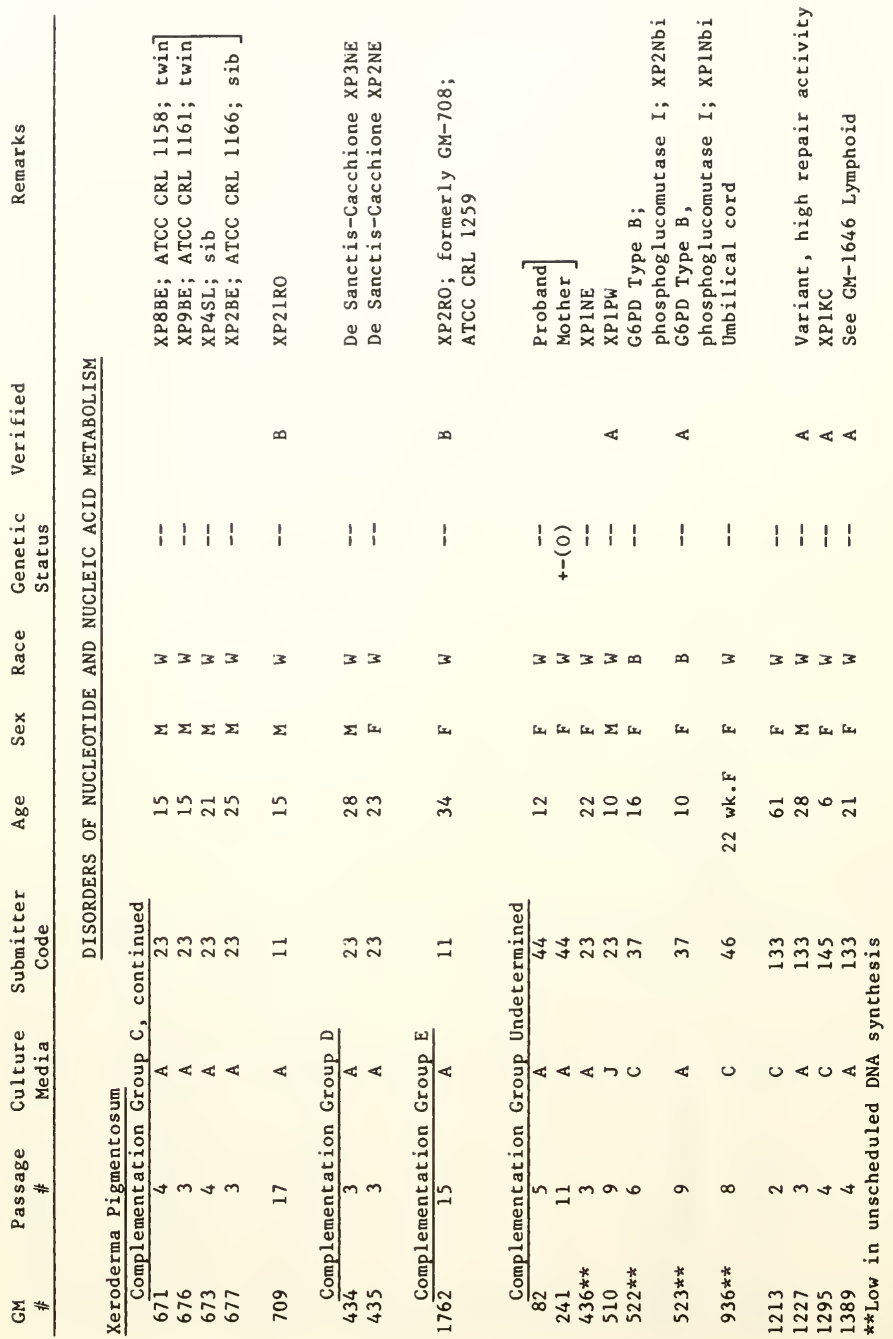




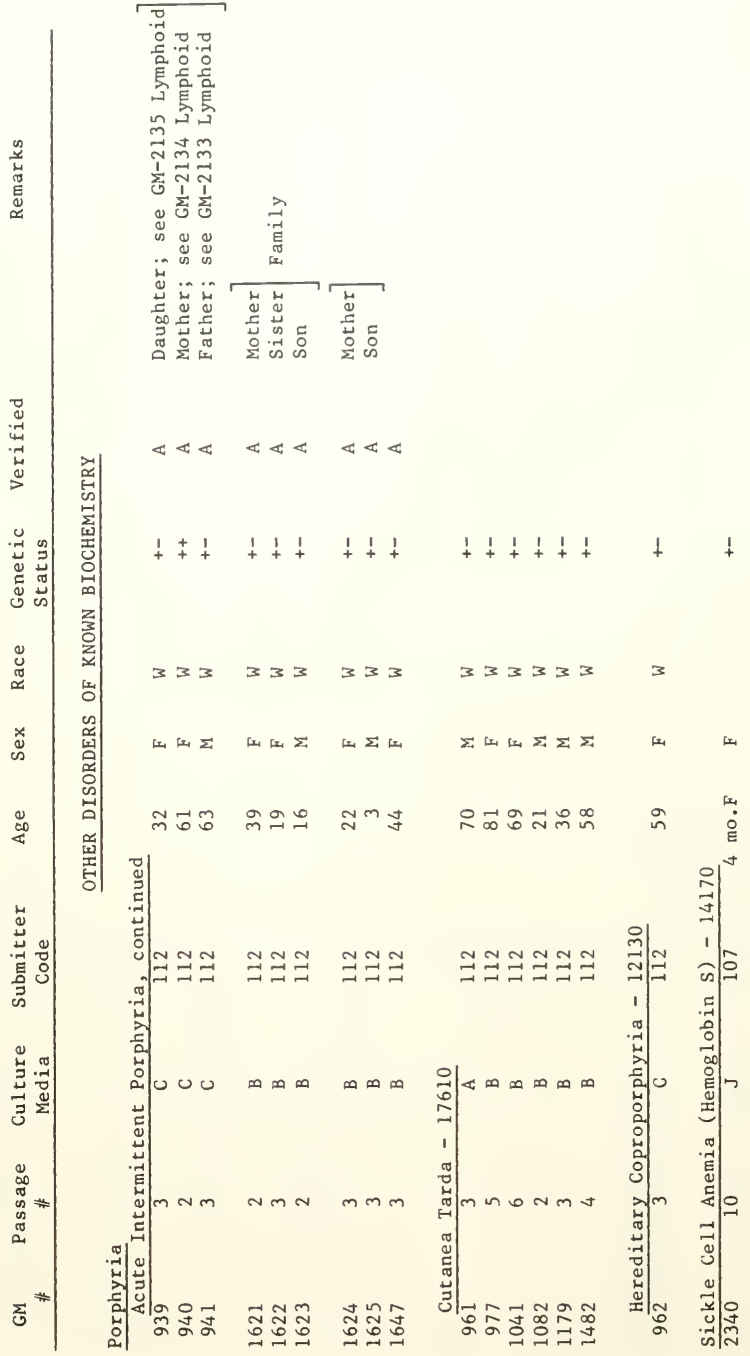




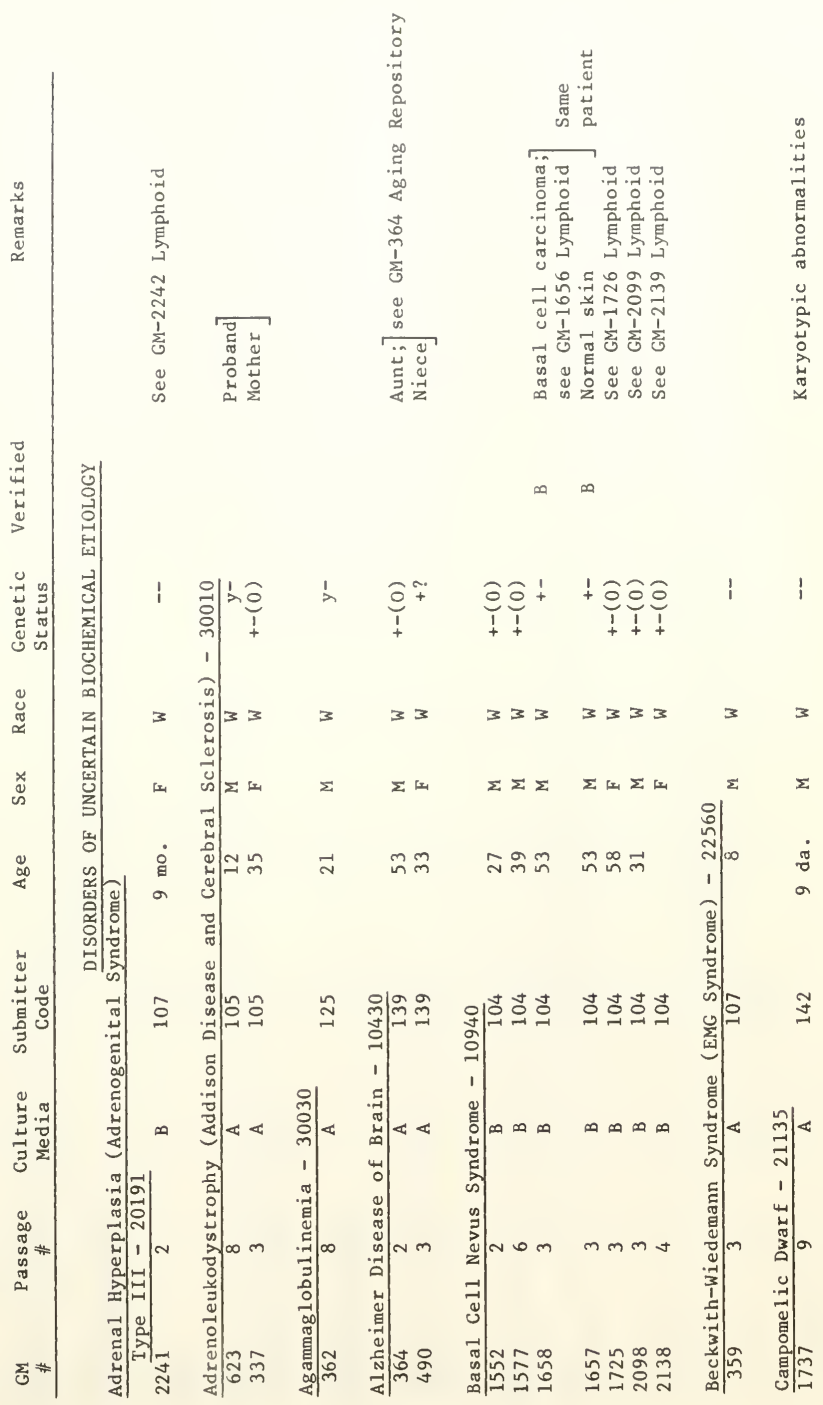




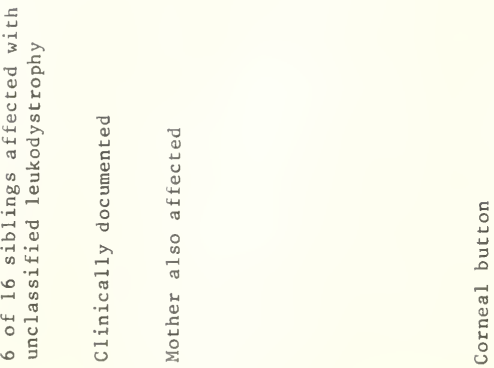

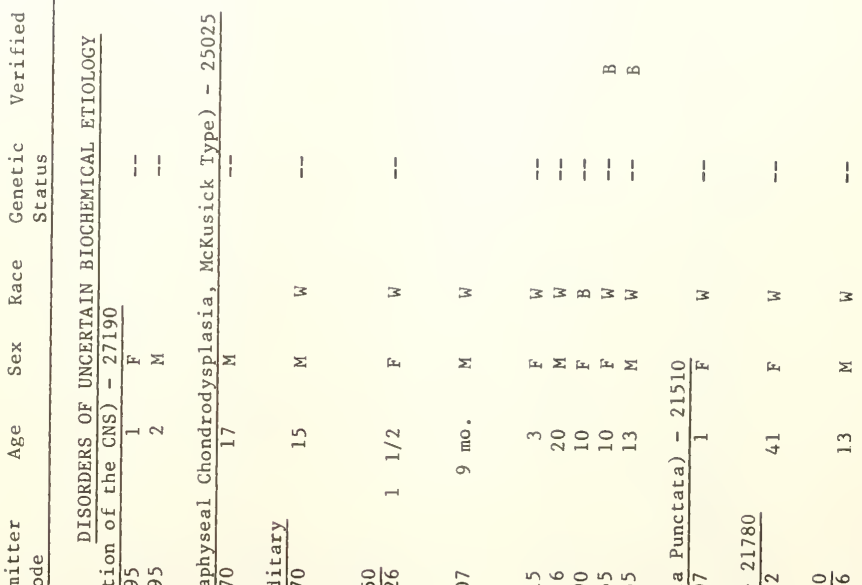

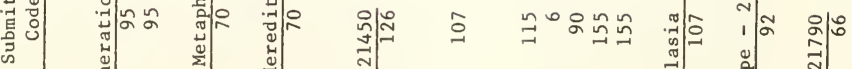

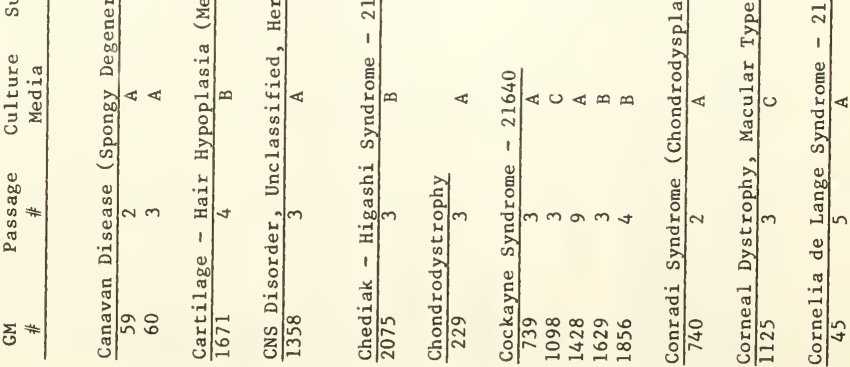




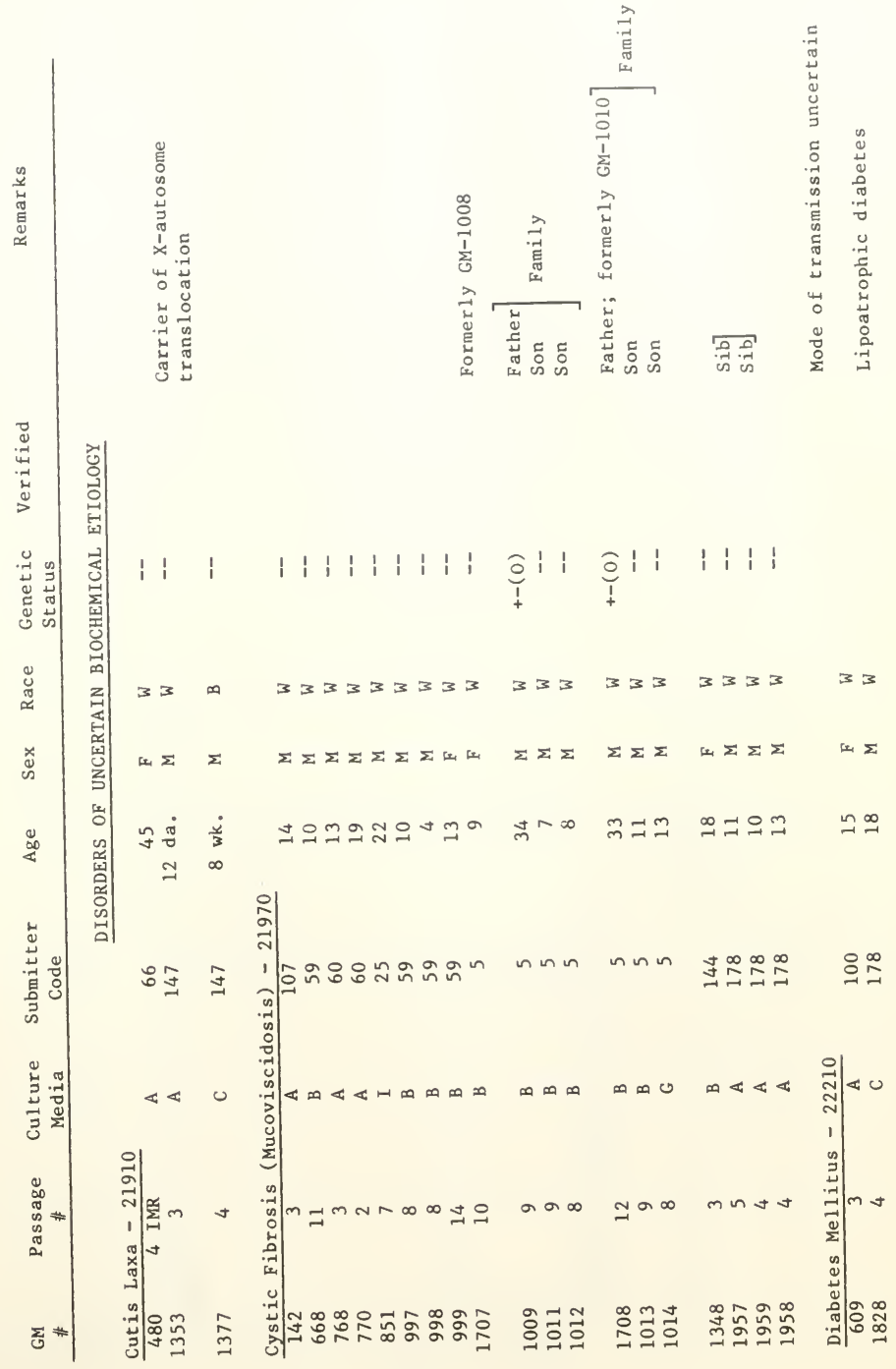




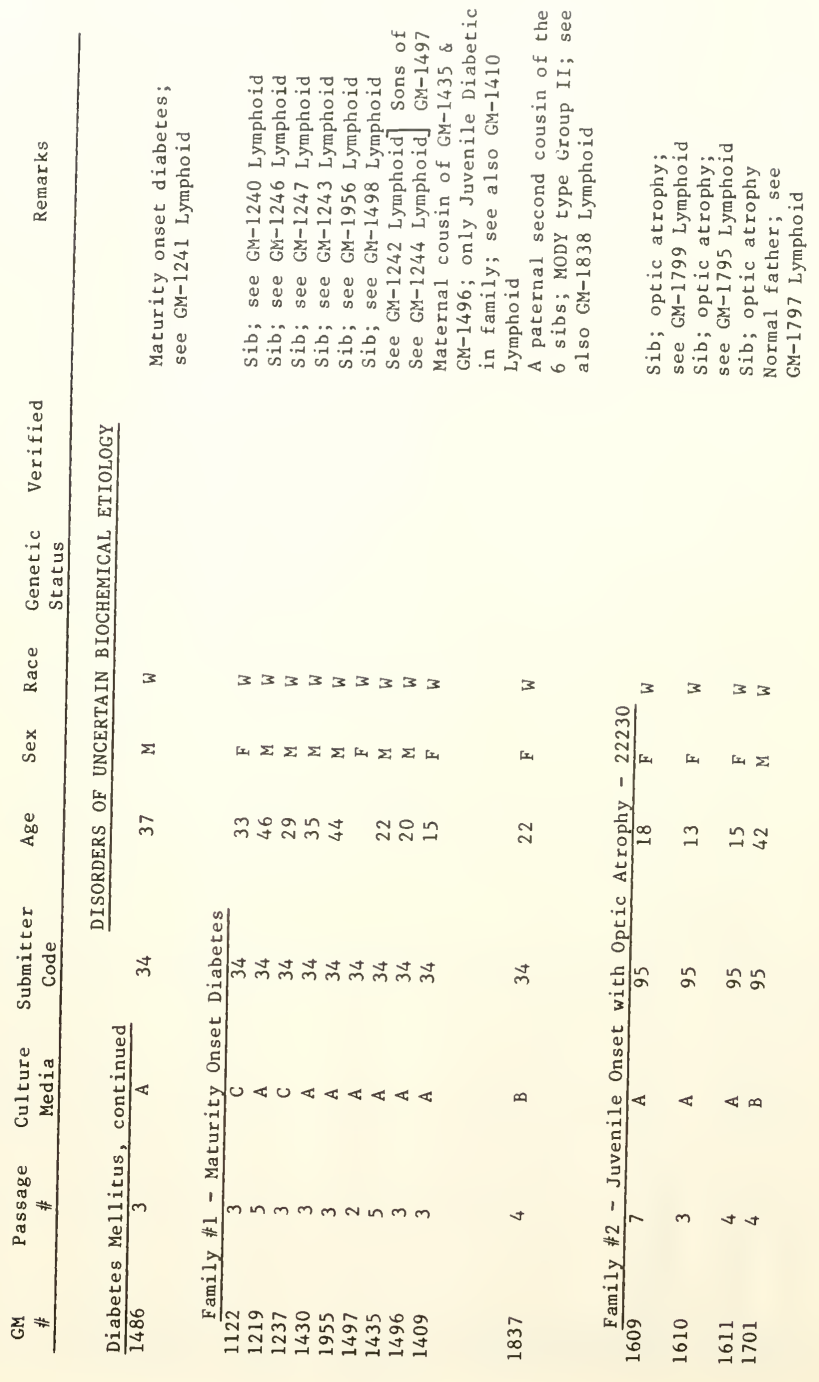




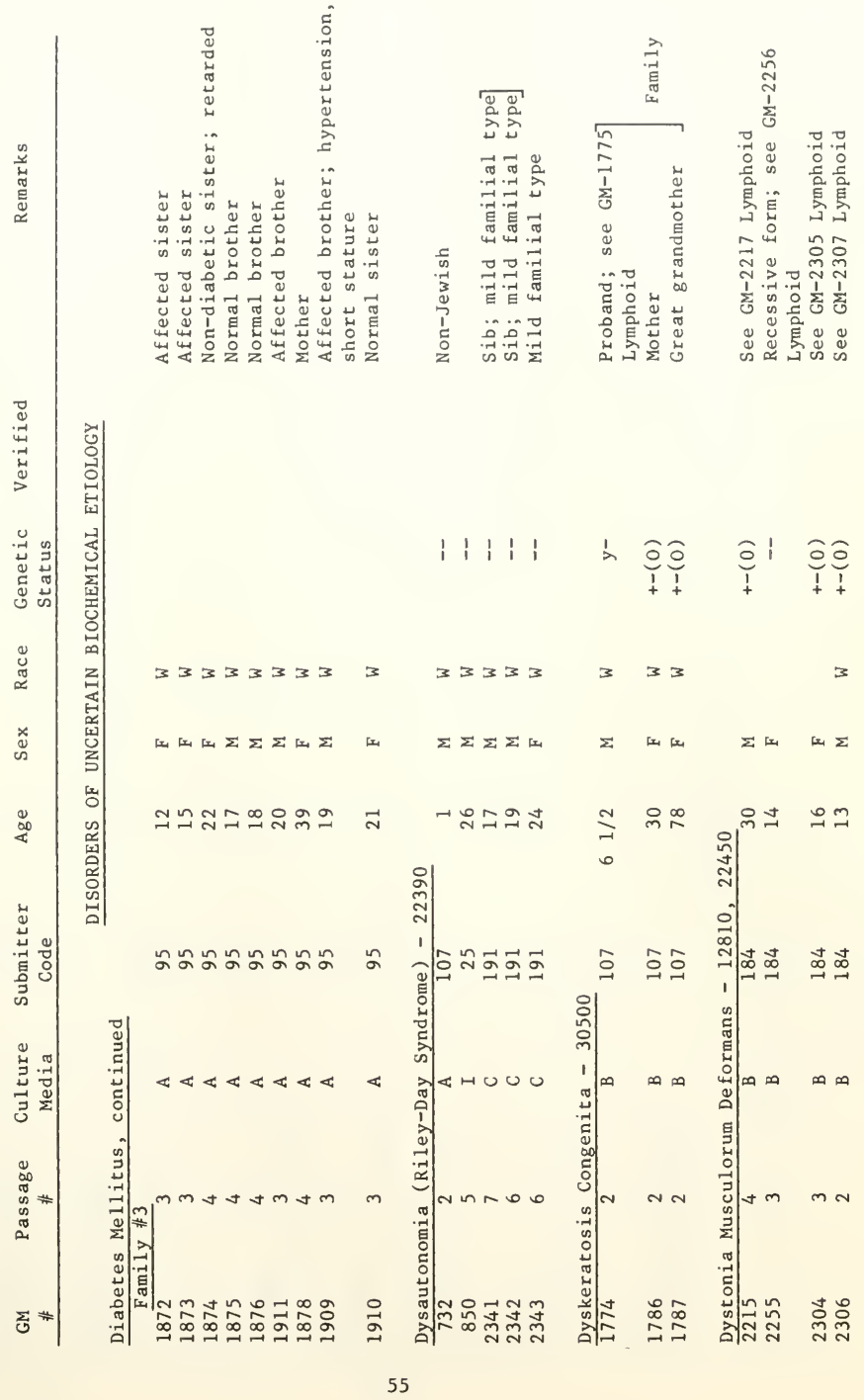




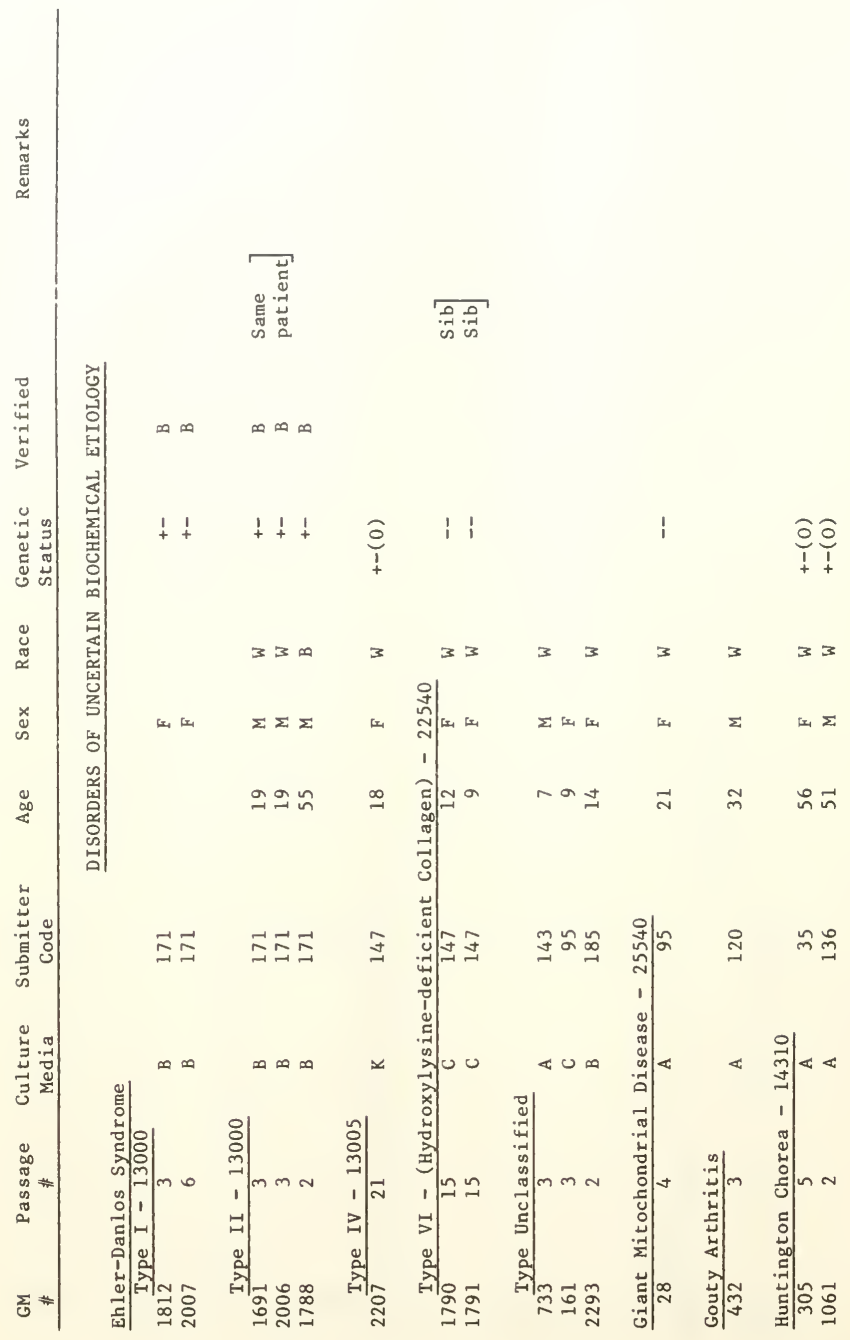




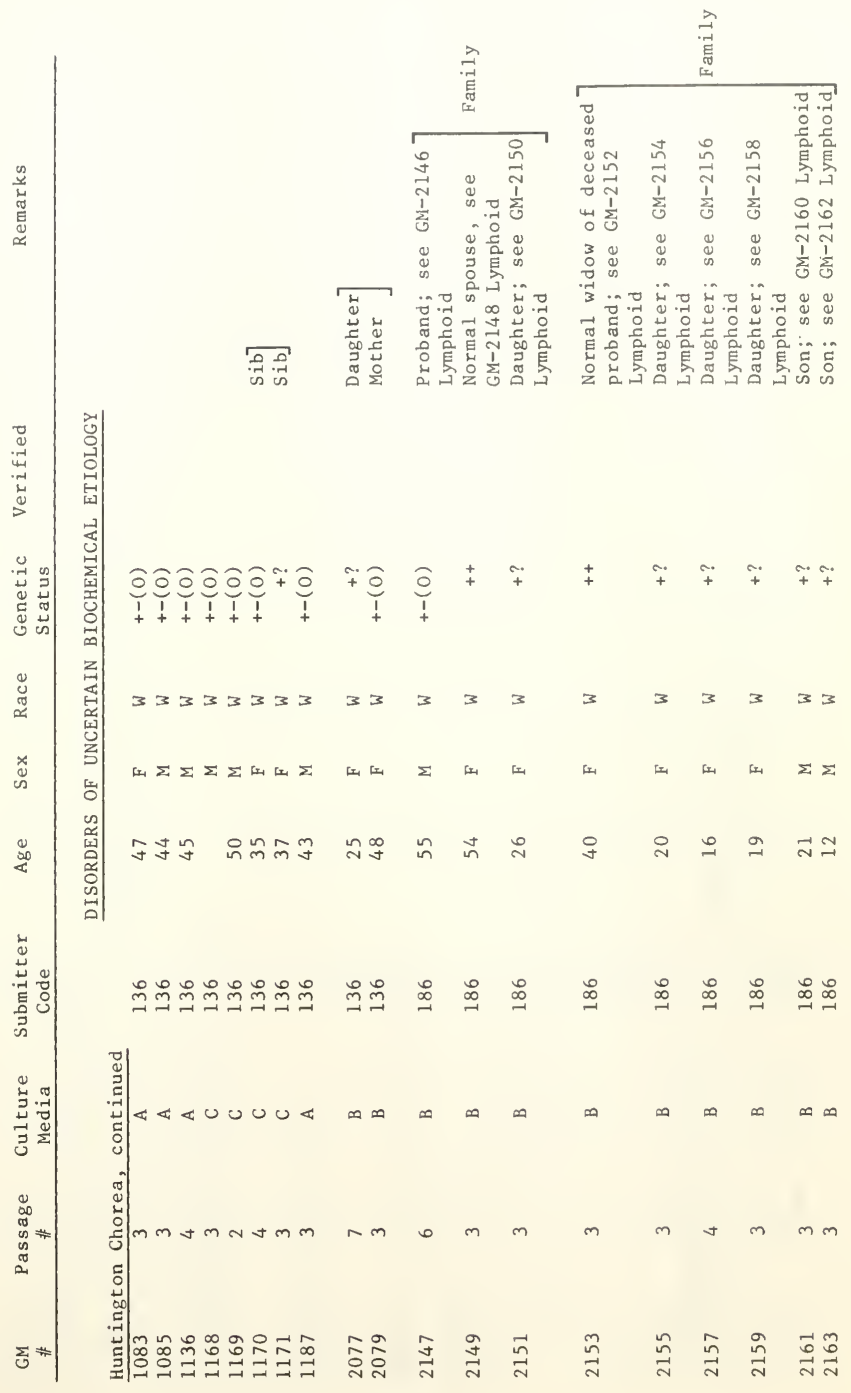




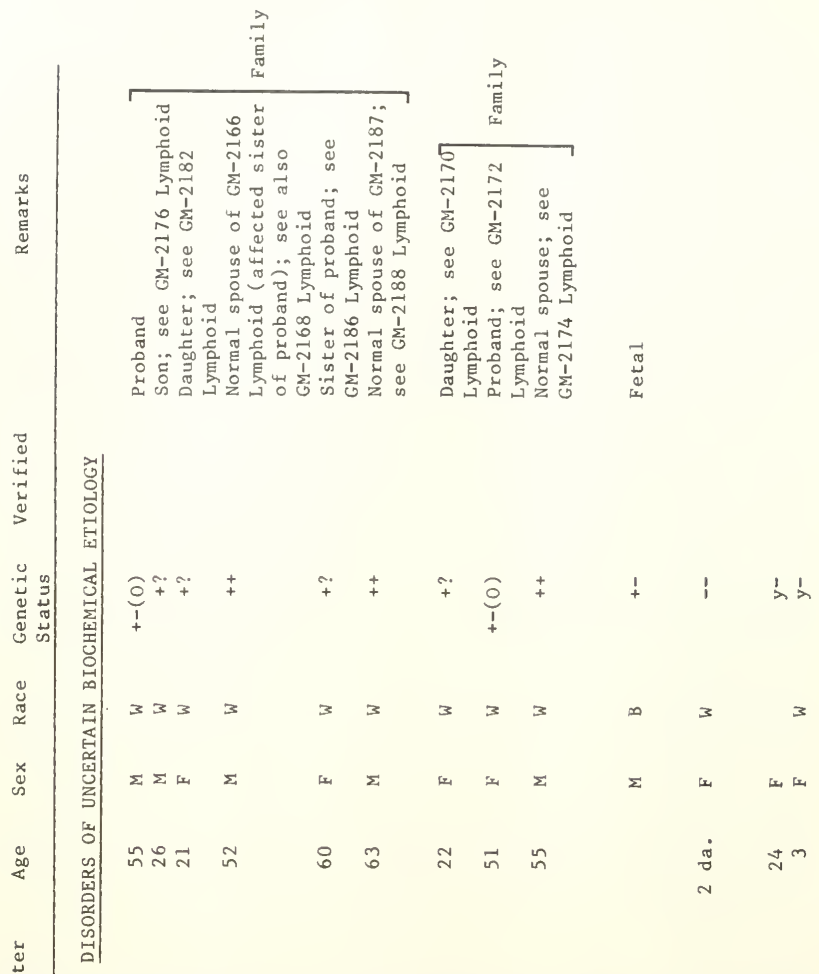

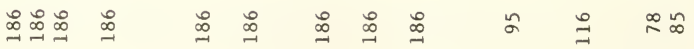

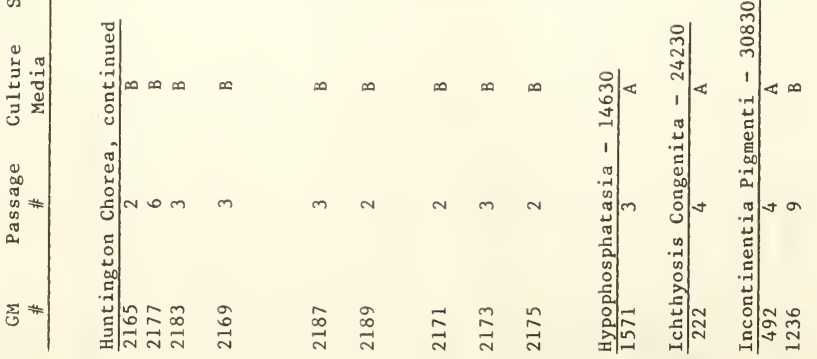




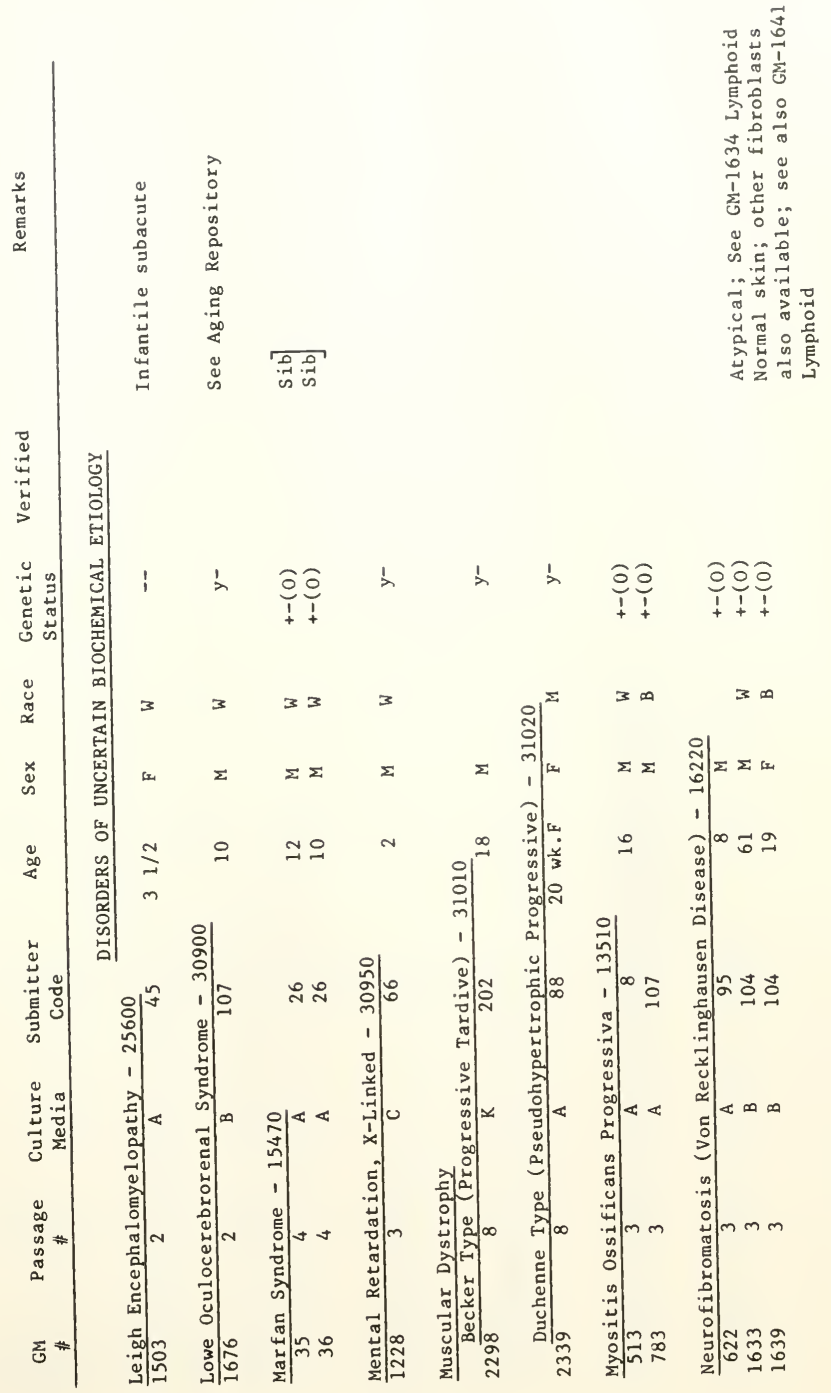




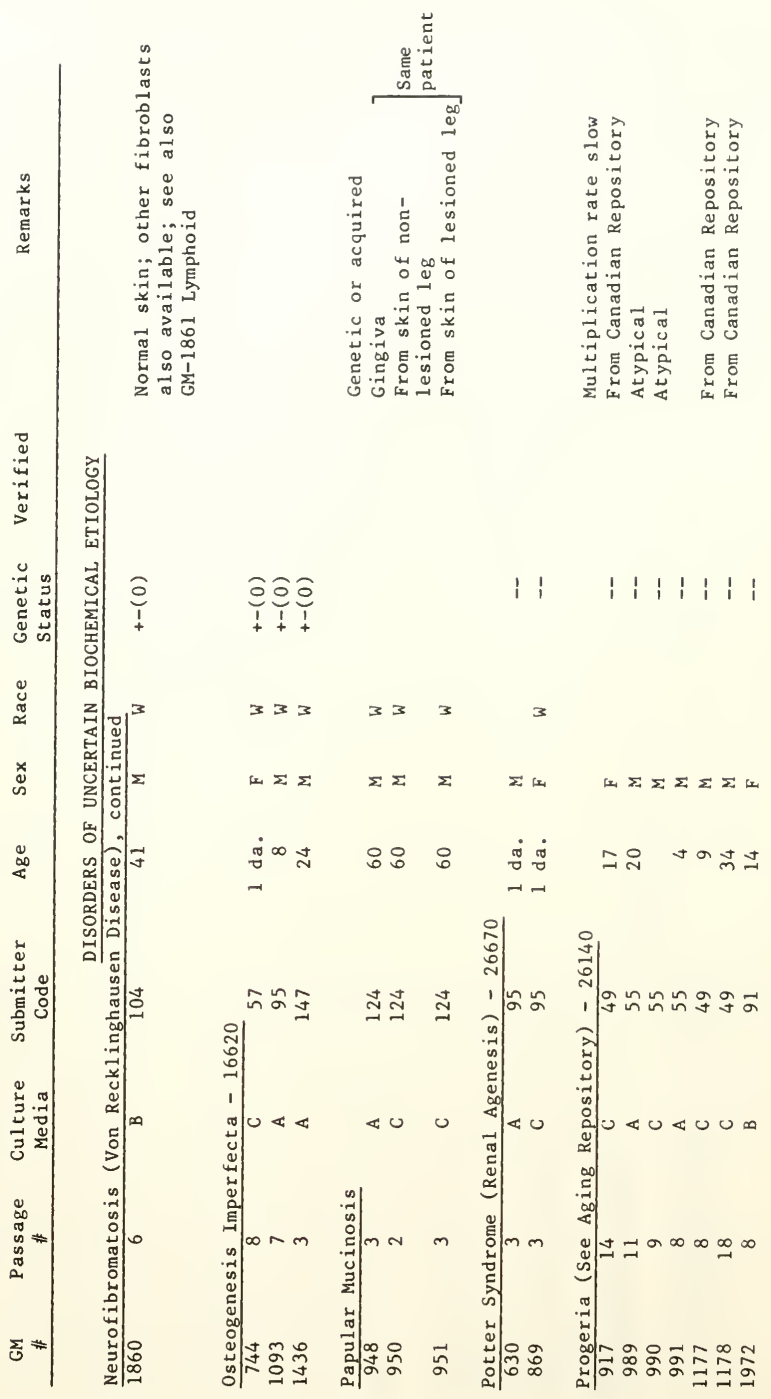




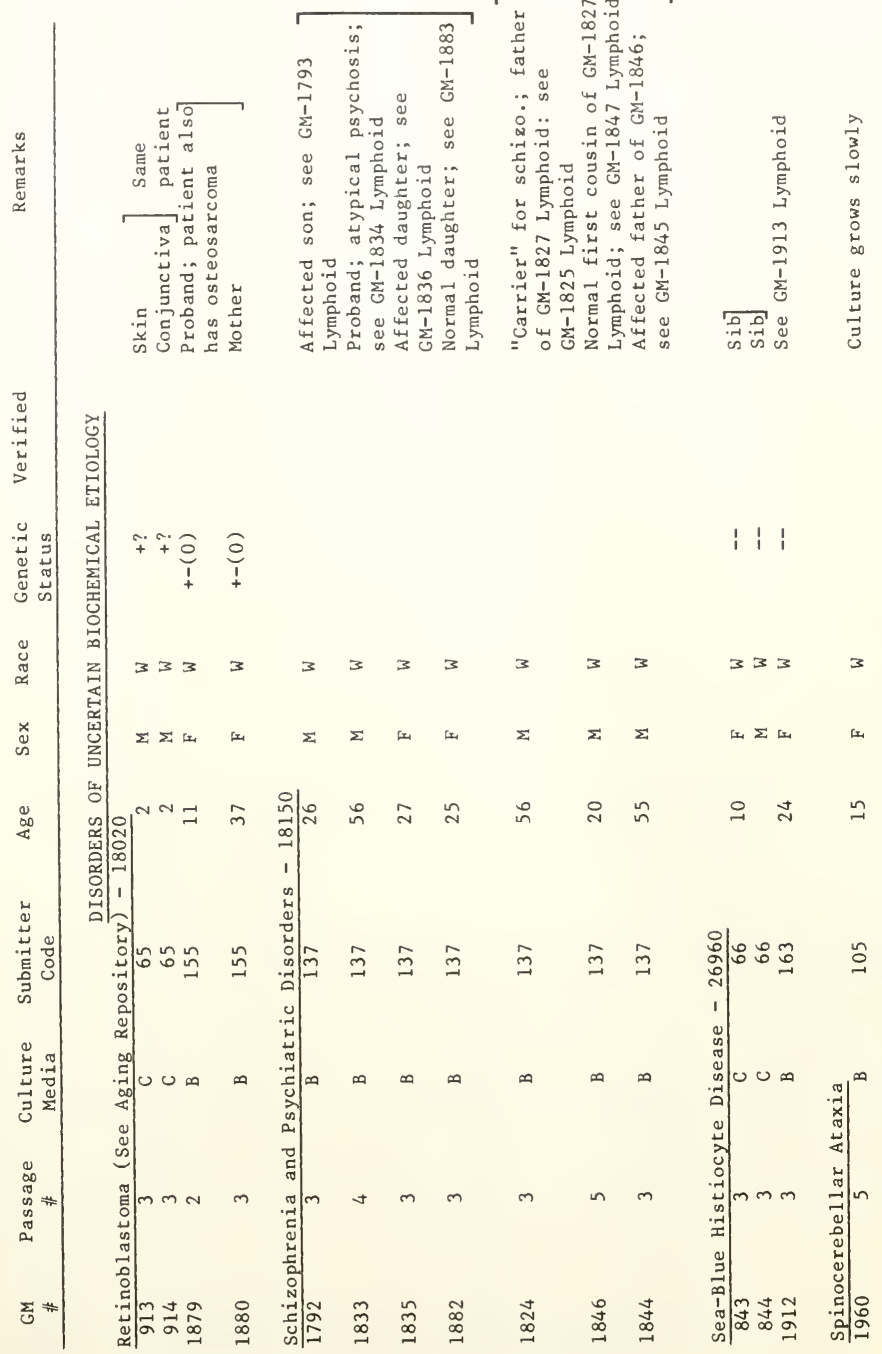




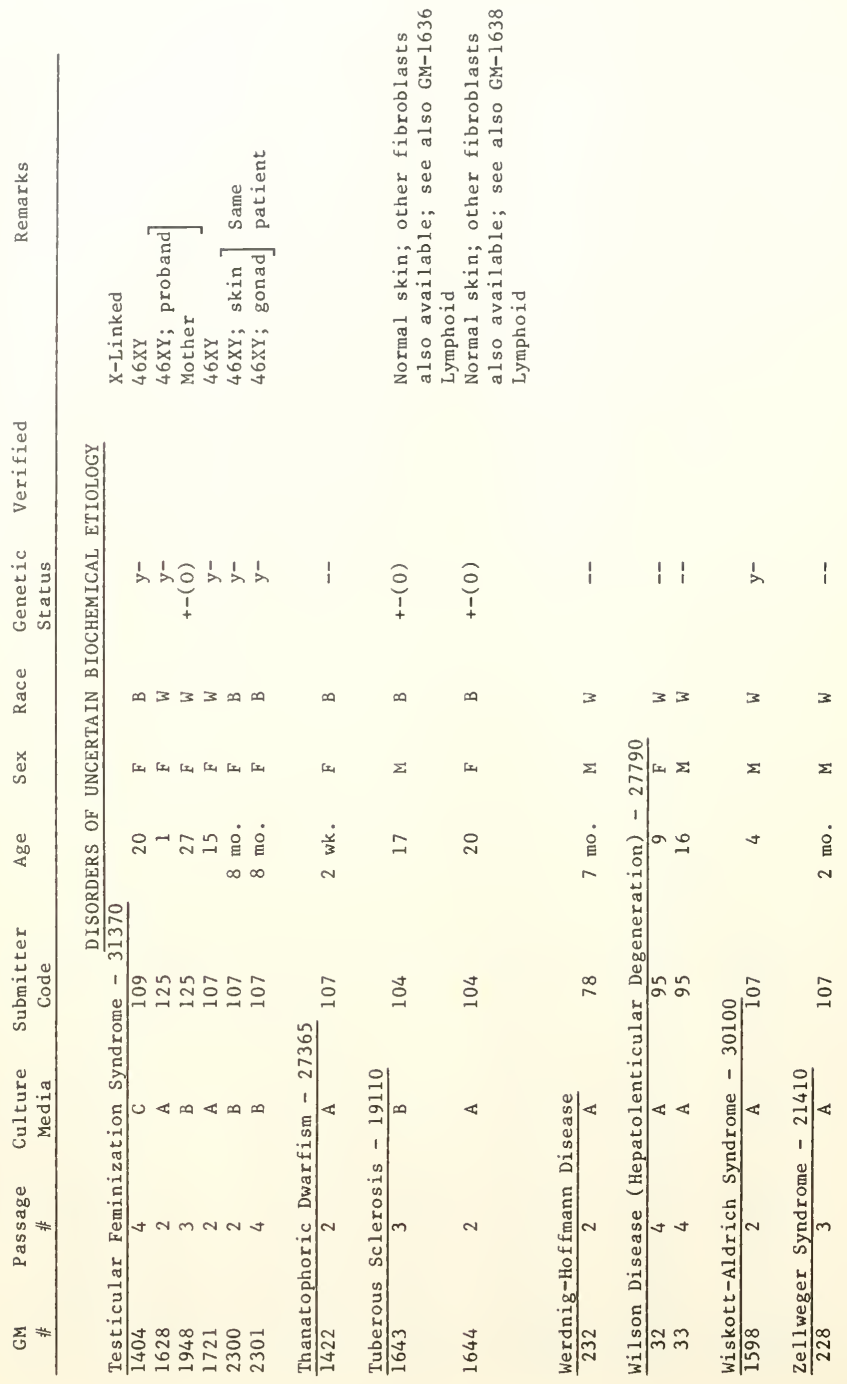




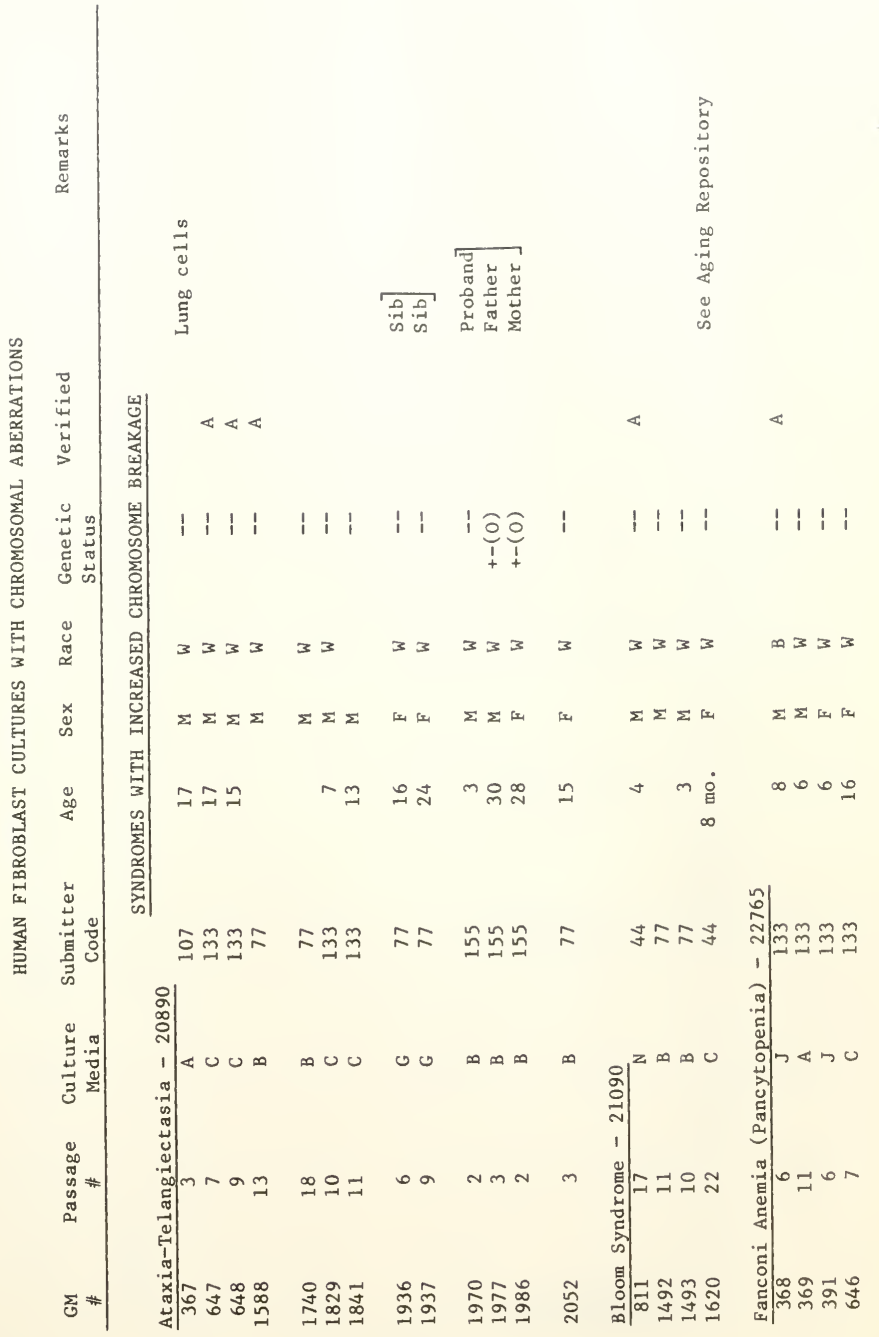




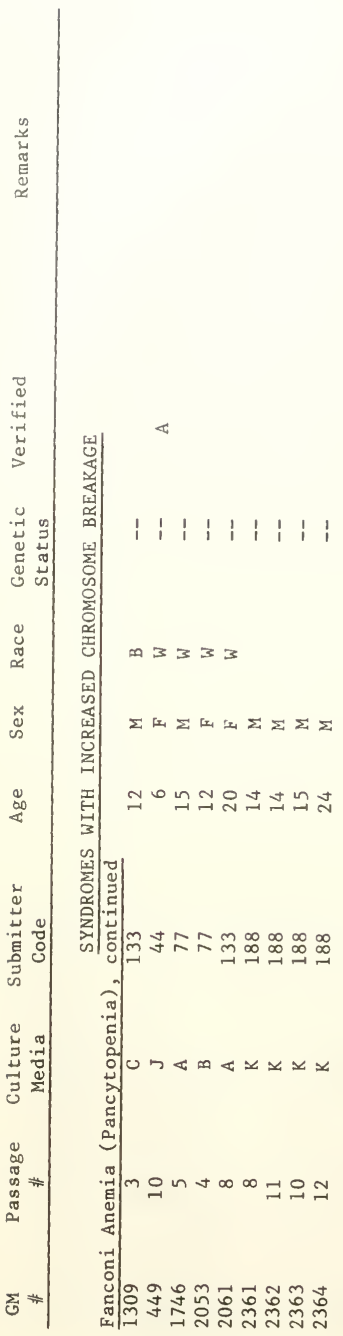




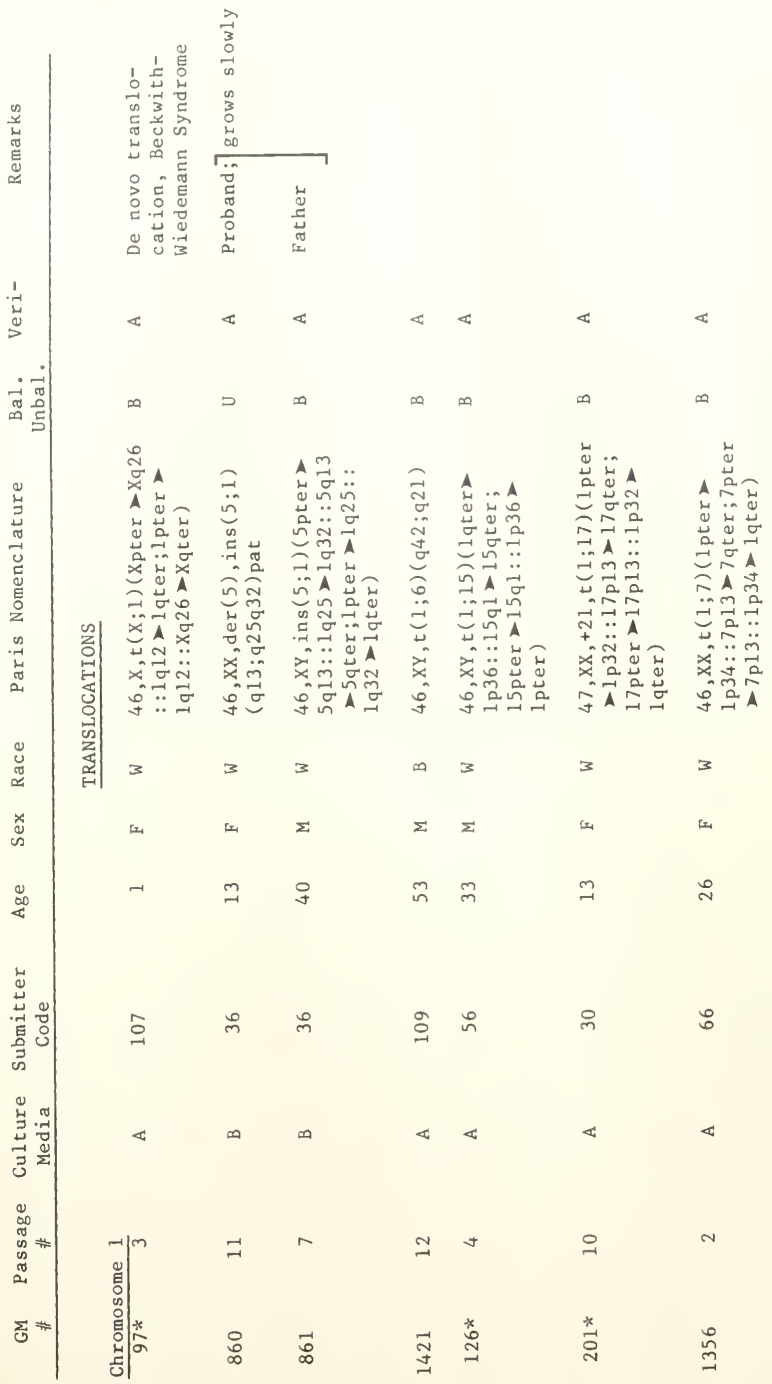

을 


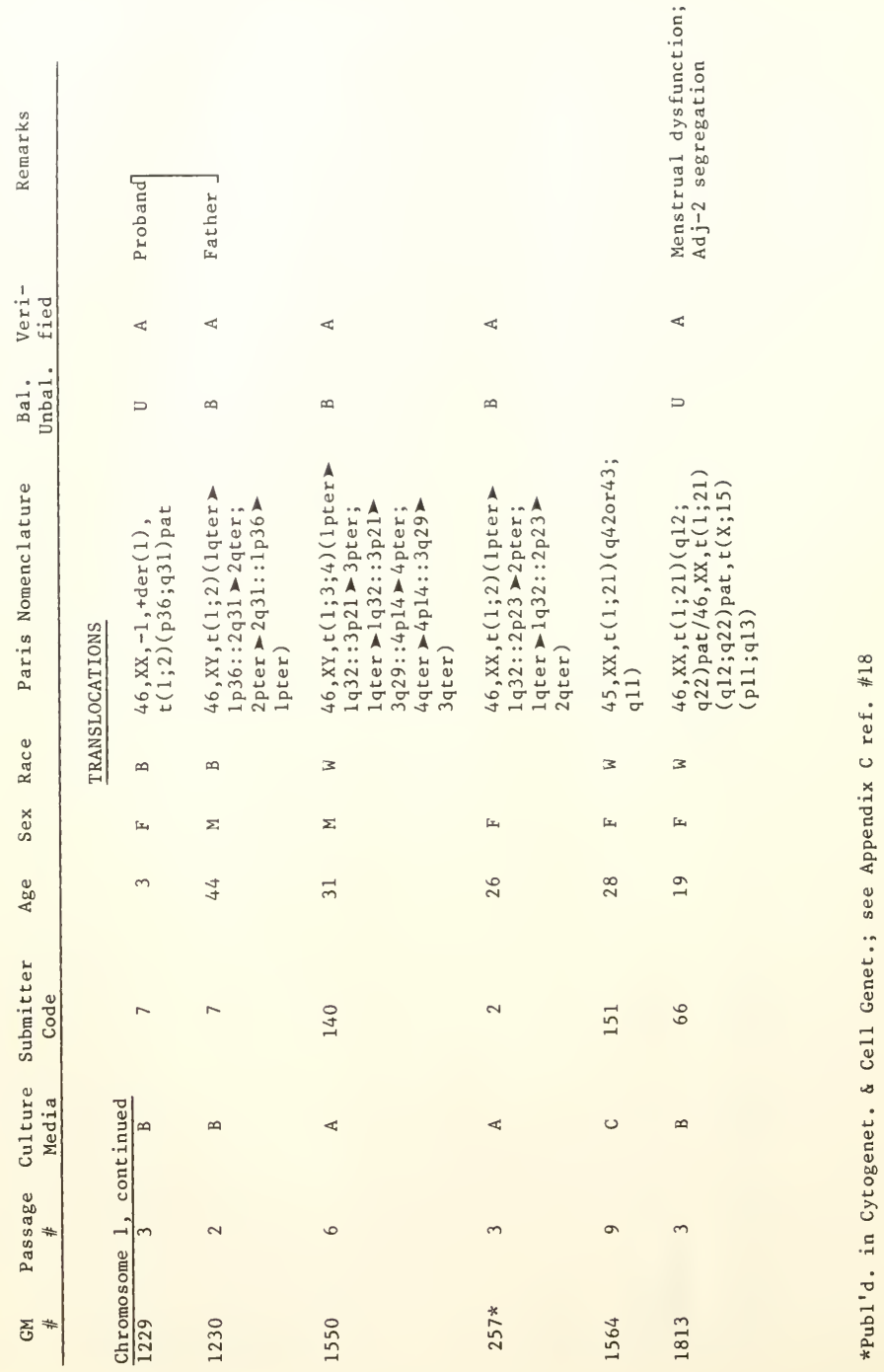




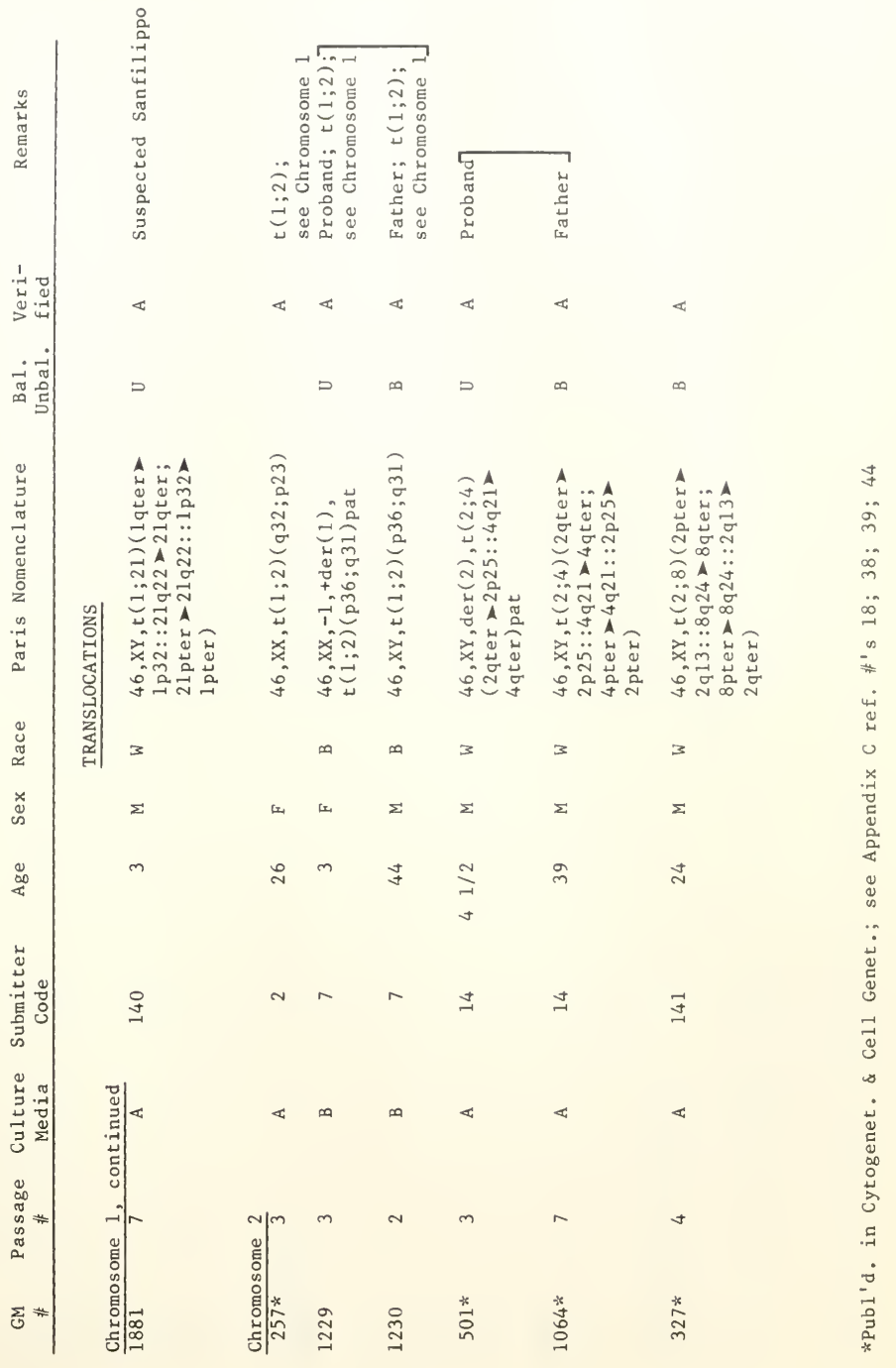




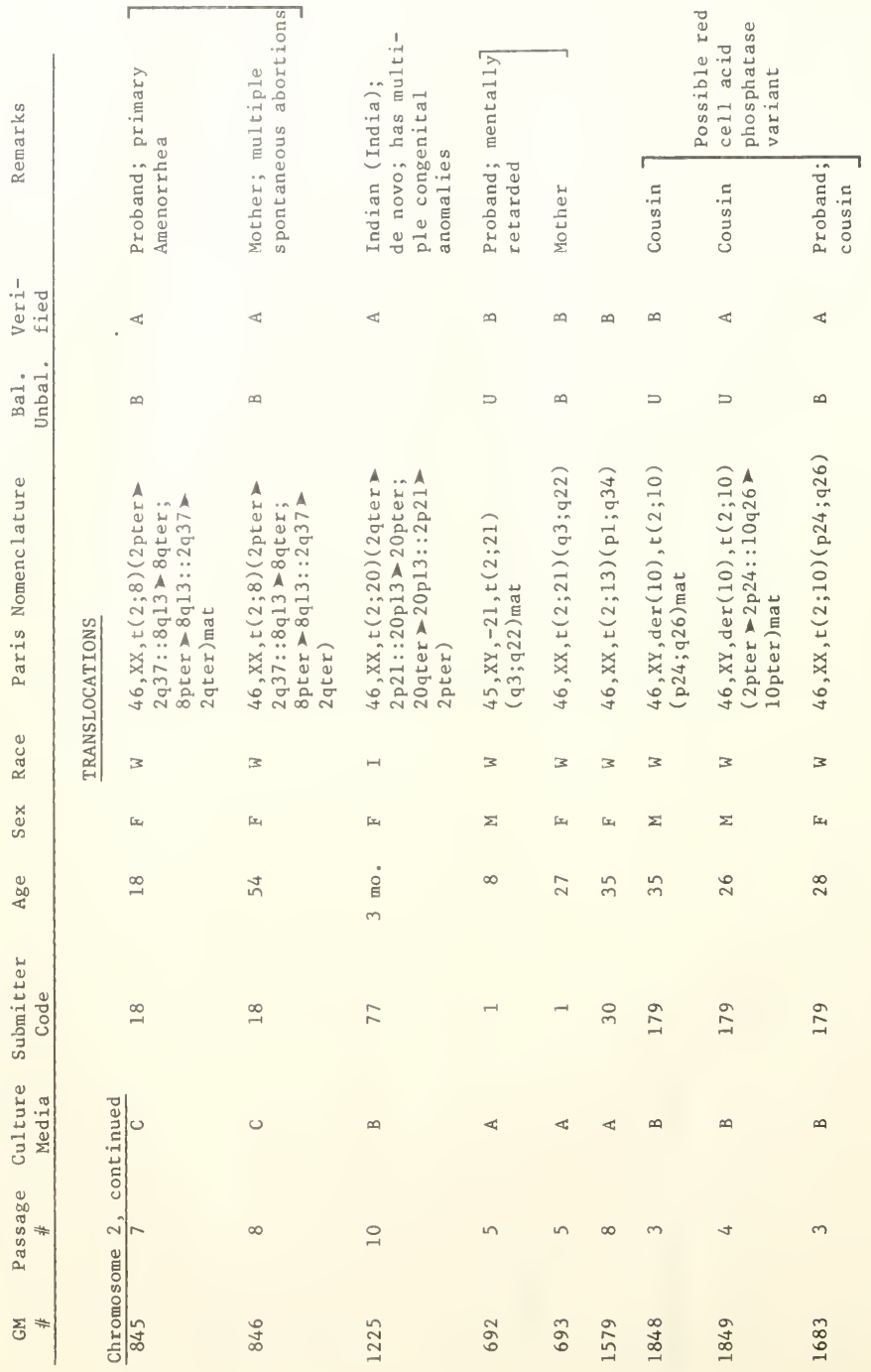




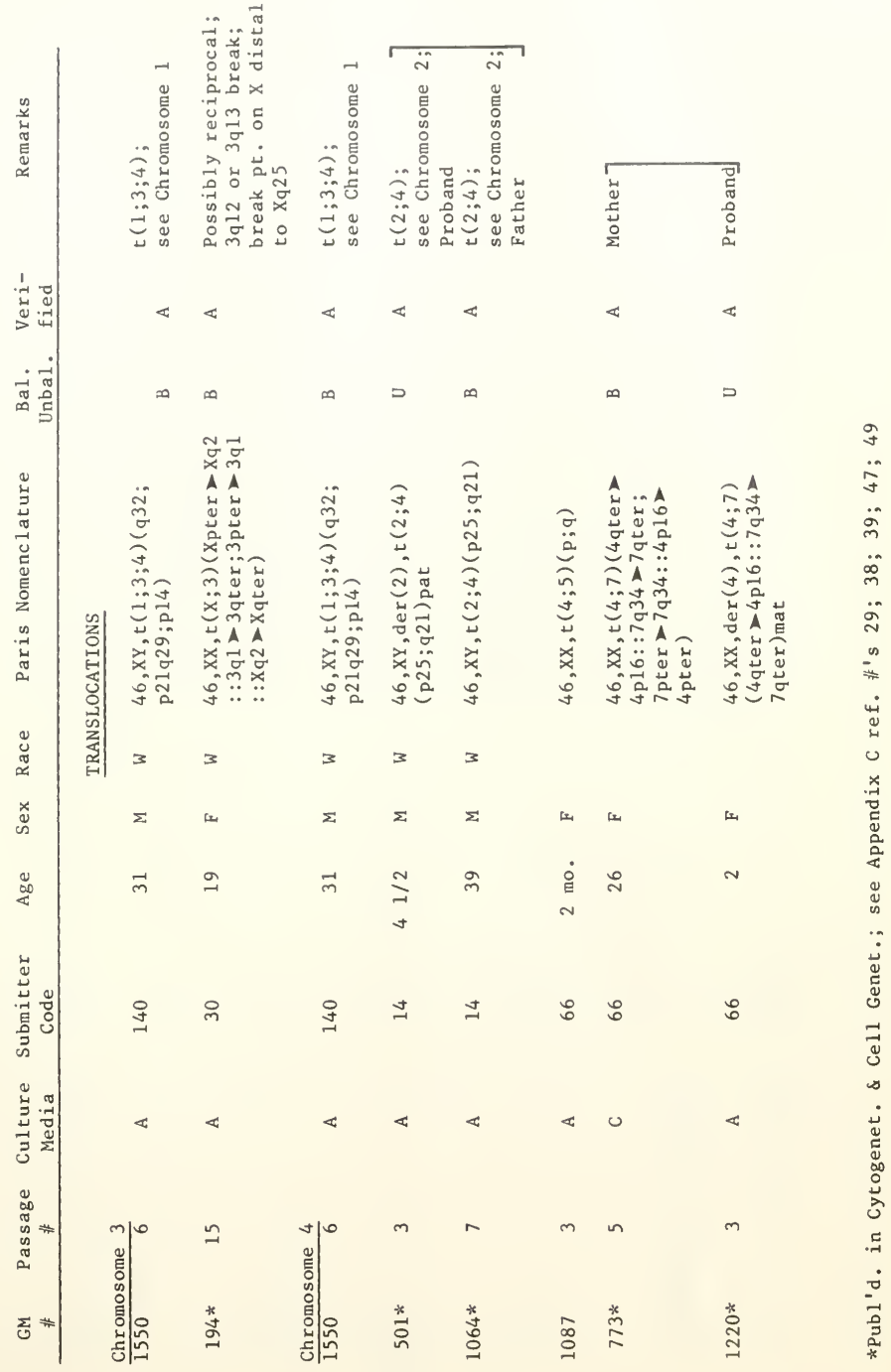




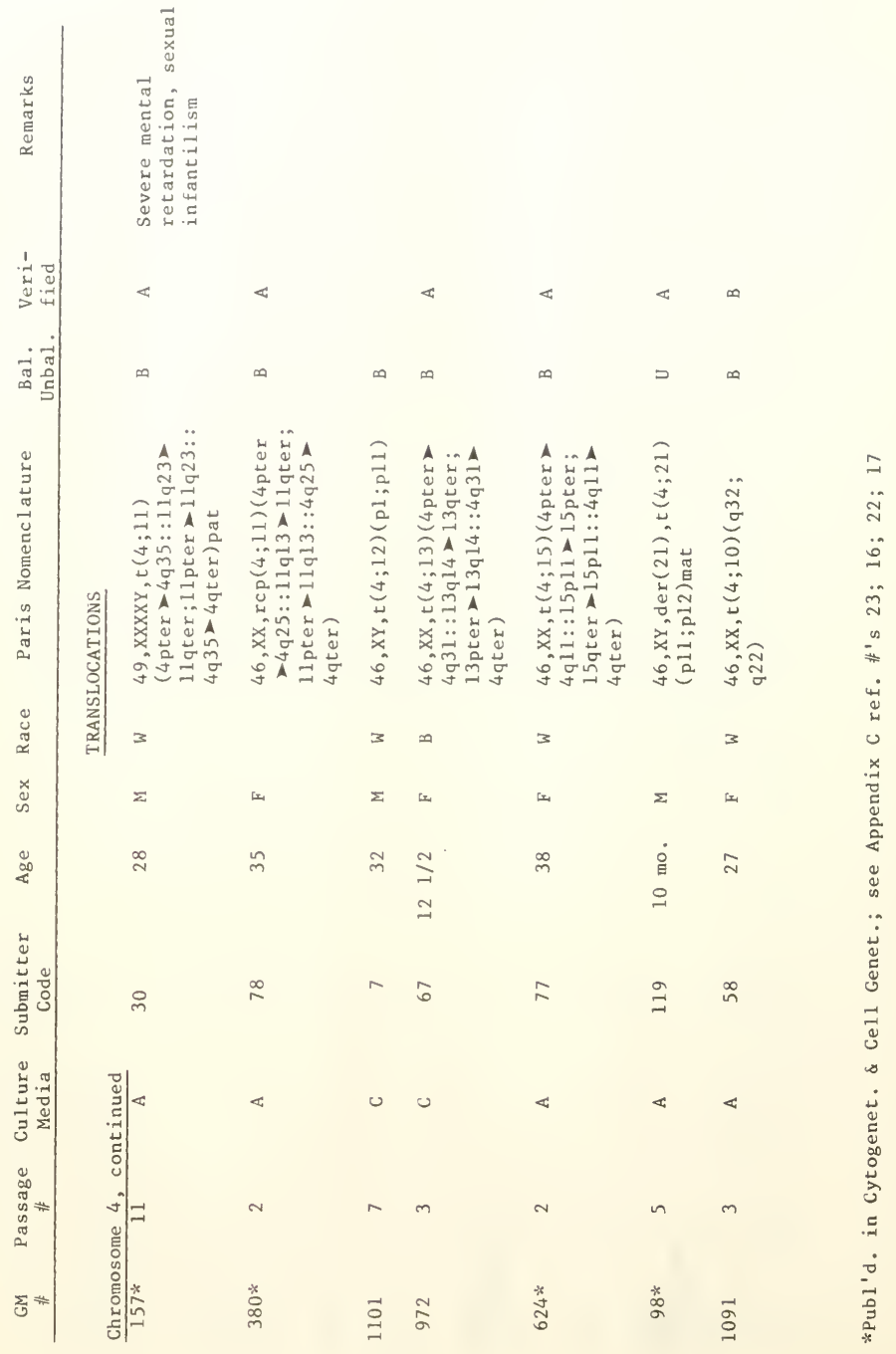




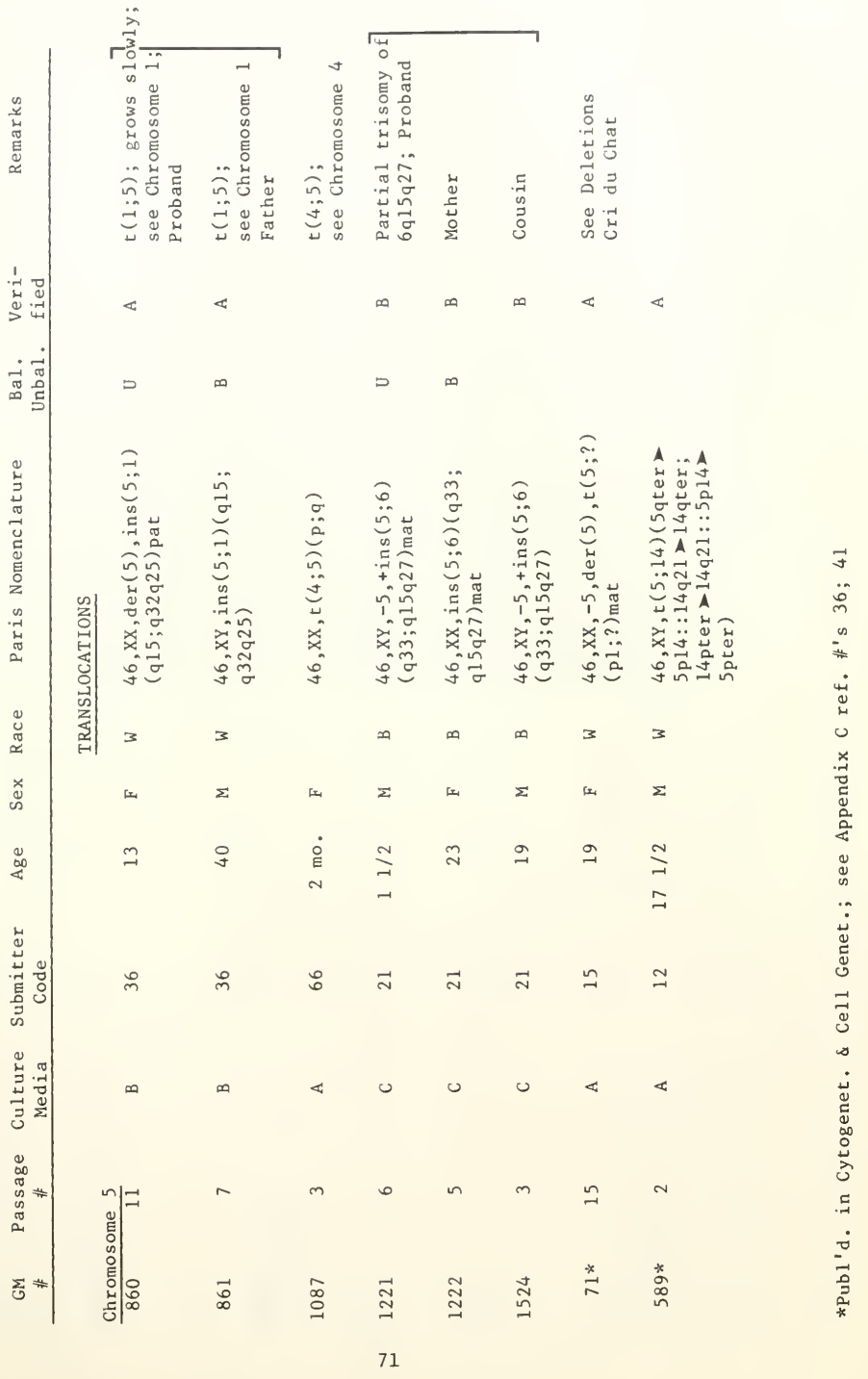




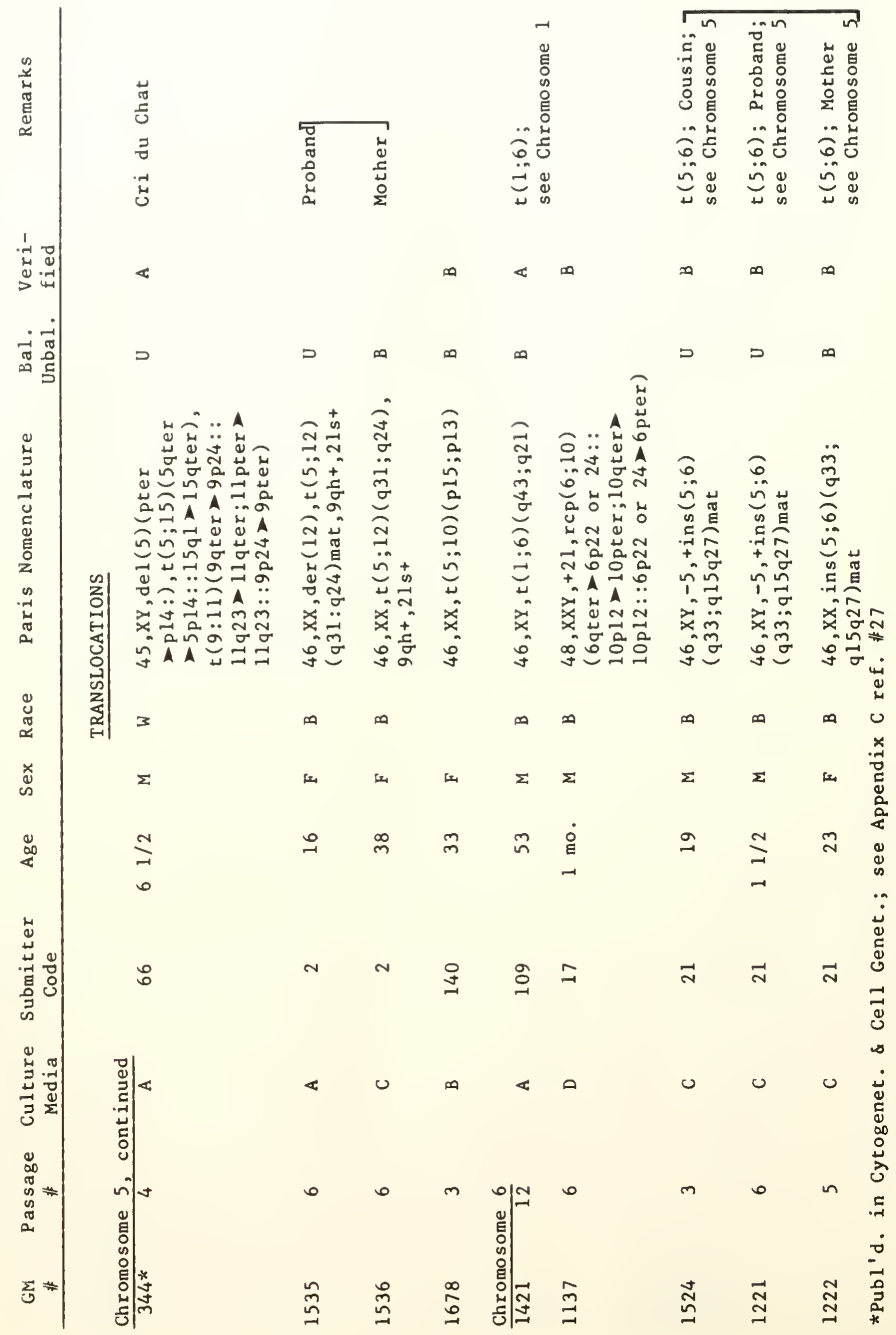




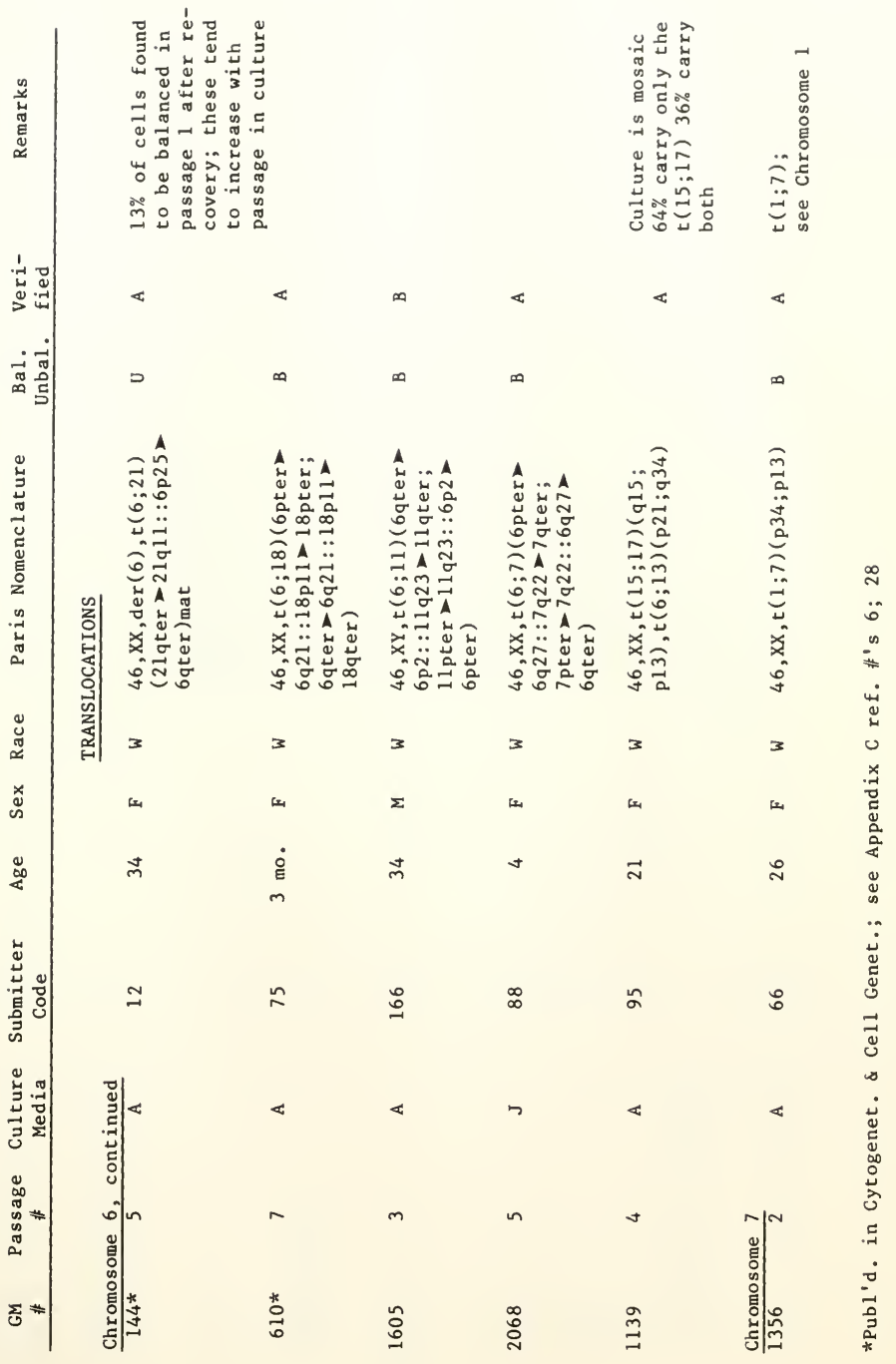




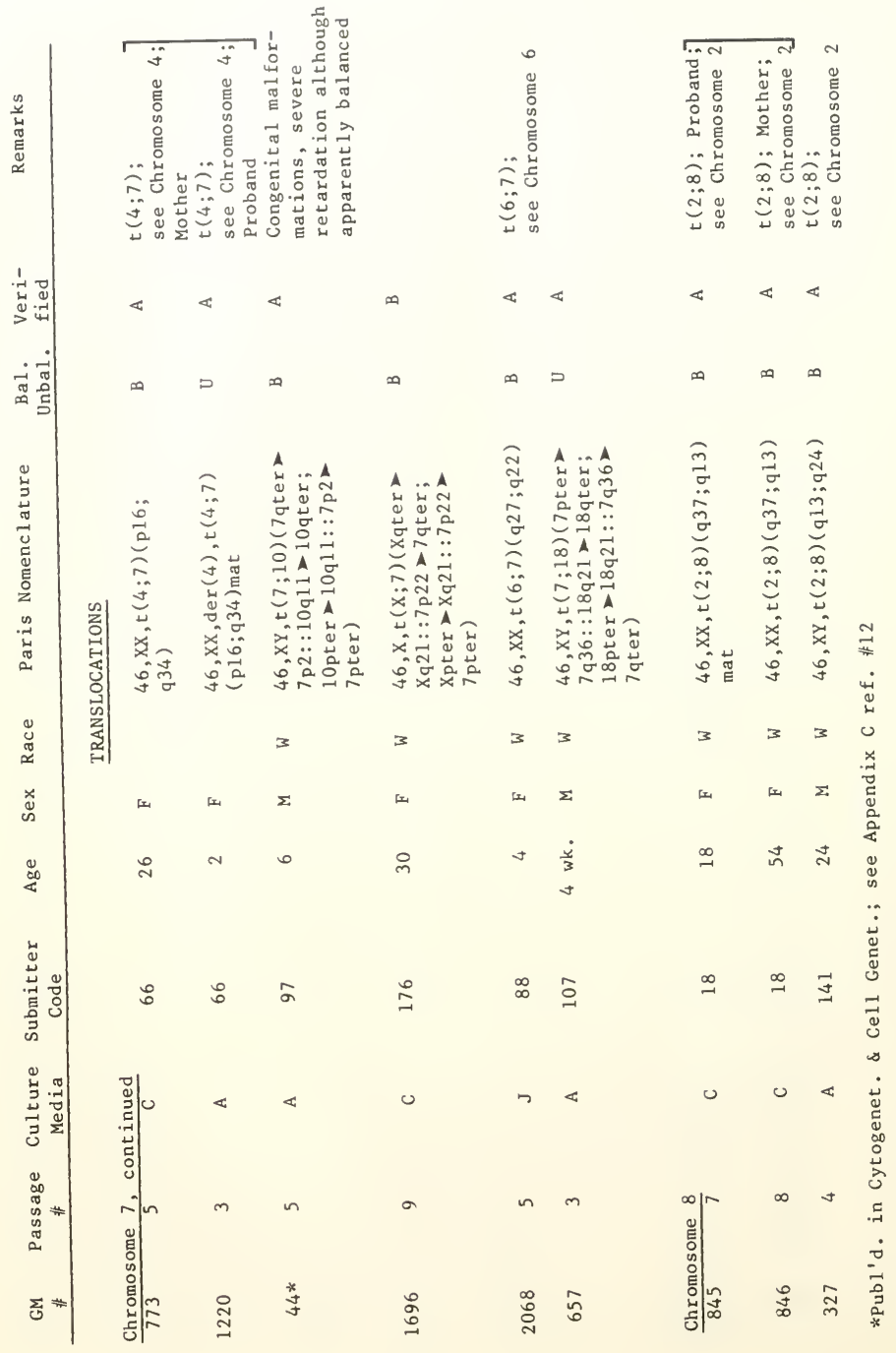




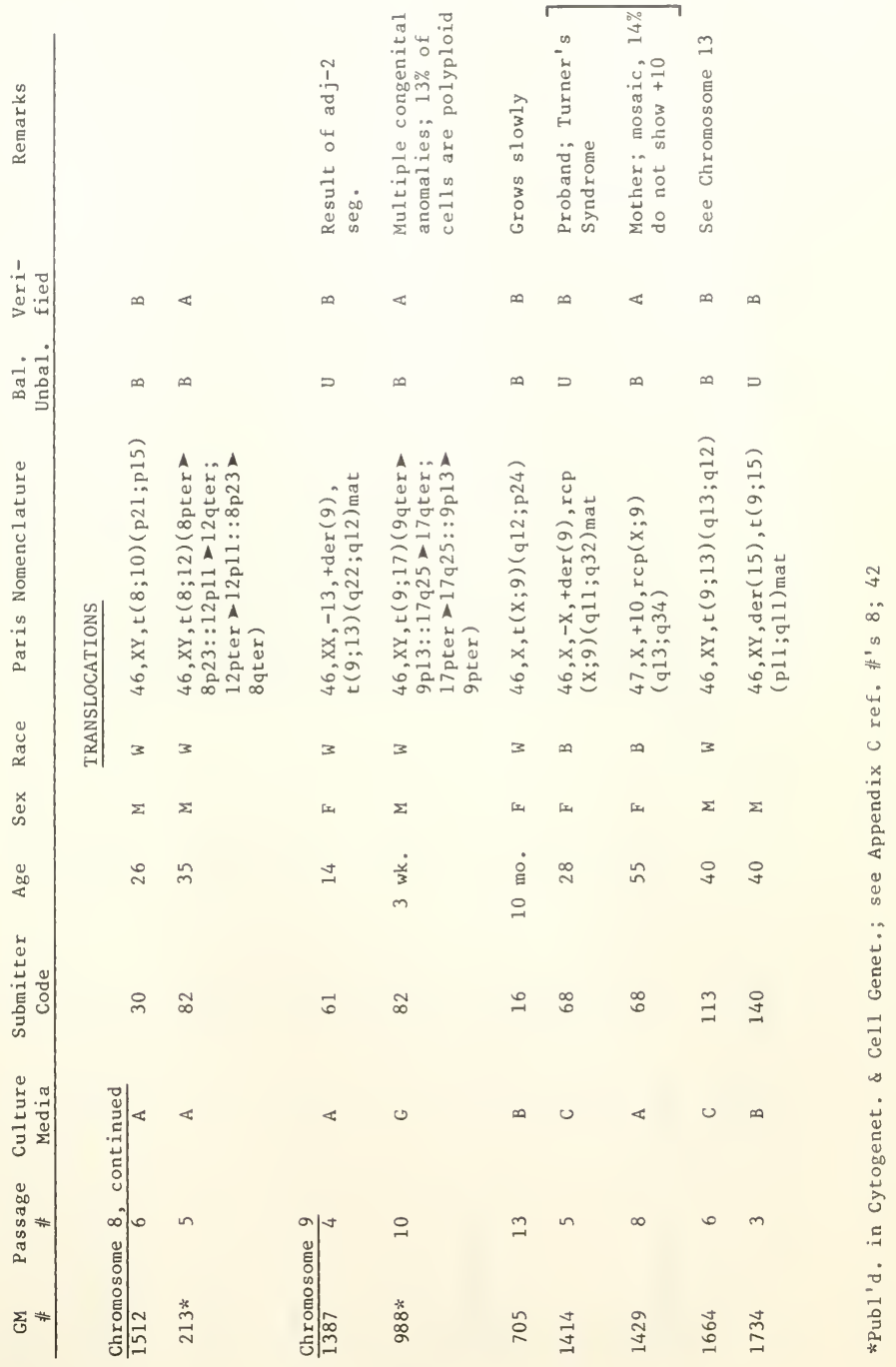




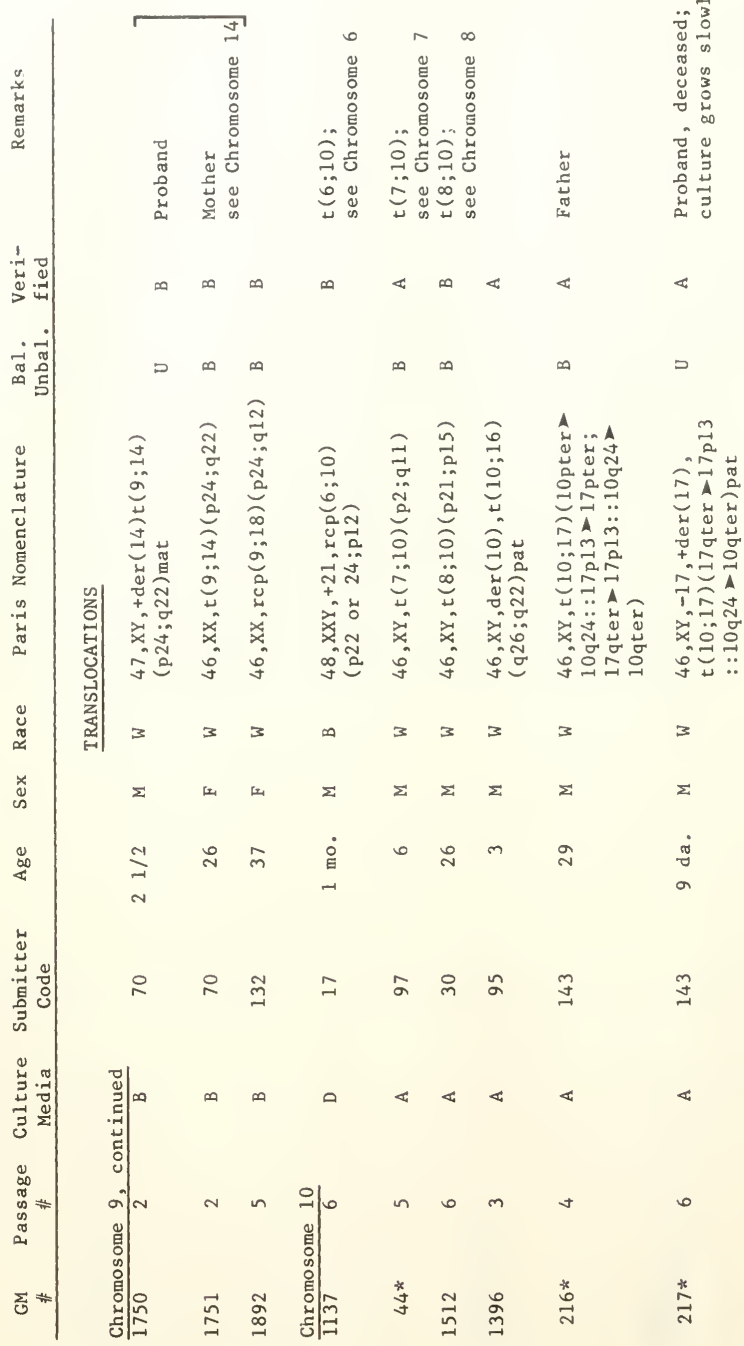




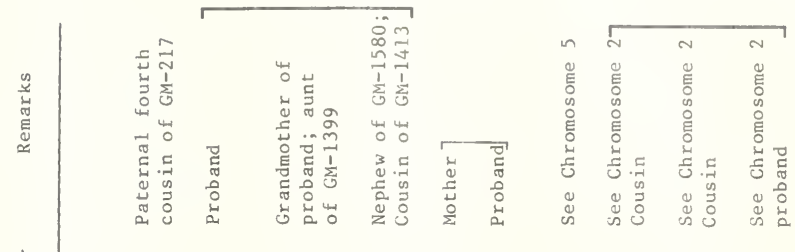

岁

चै

$\varangle$

$\infty \quad \infty$

$\infty \quad \varangle$

䑰

م.

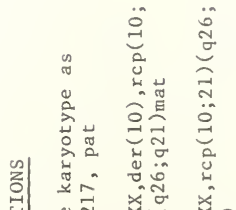

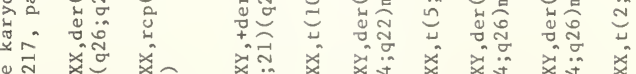

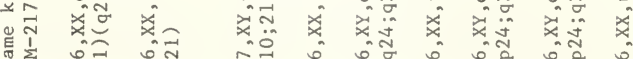

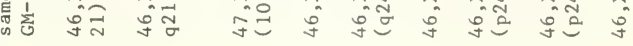

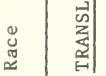

3

$\infty \infty$

$\infty$

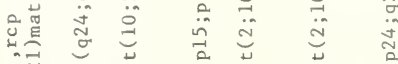

กิ

تิن

पू山

ঐ

$\stackrel{\infty}{\infty}$

品

ต

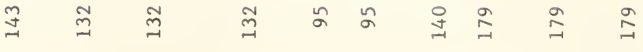

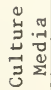

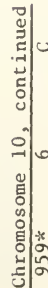

$\infty$

$\infty$

$\infty$

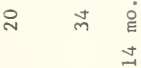

$m \stackrel{m}{m} \stackrel{0}{\sim} \stackrel{\infty}{\sim}$

$\infty$

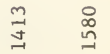

ติ

$\stackrel{1}{\infty} \infty$

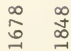

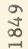

$m$
$\infty$
0 


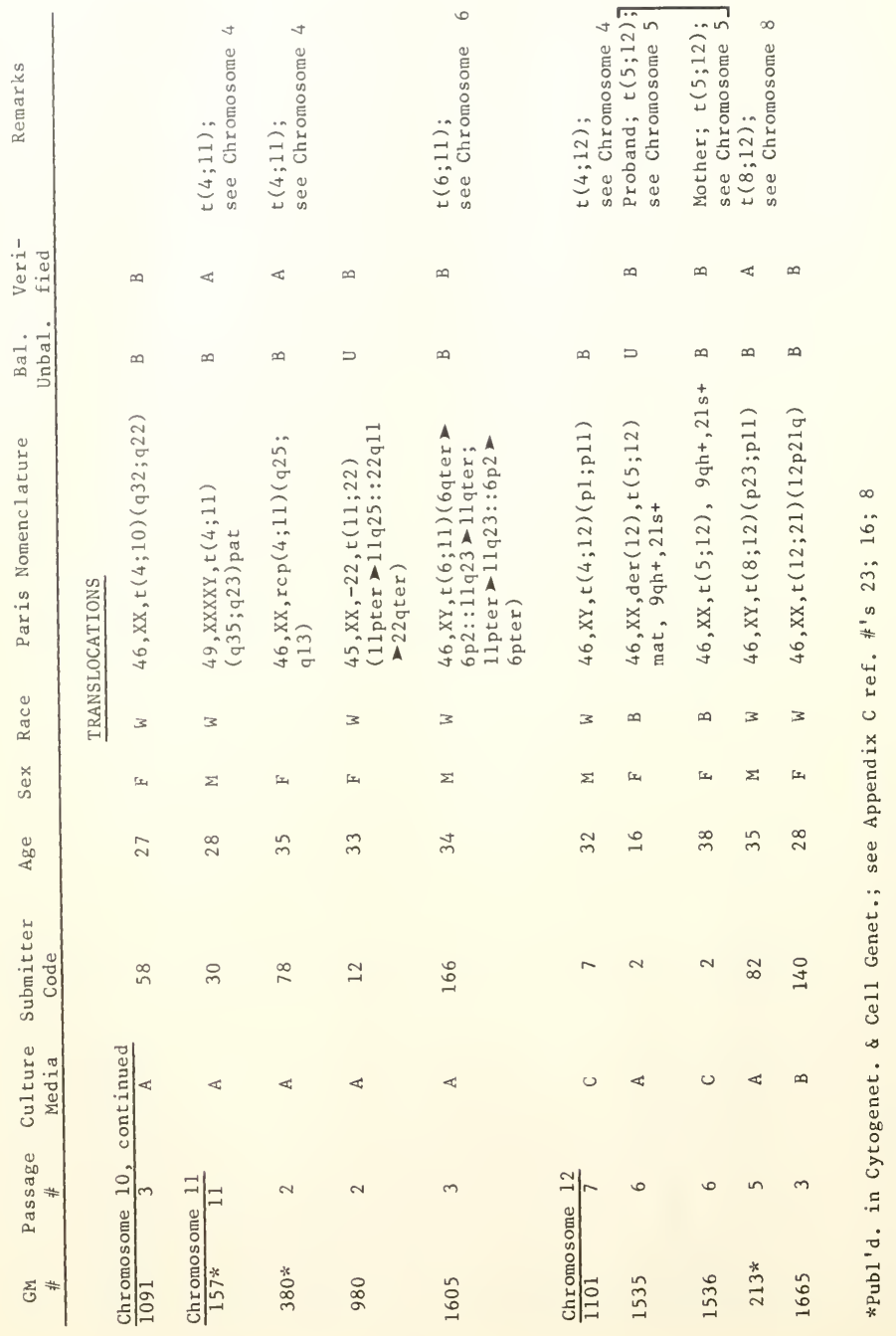




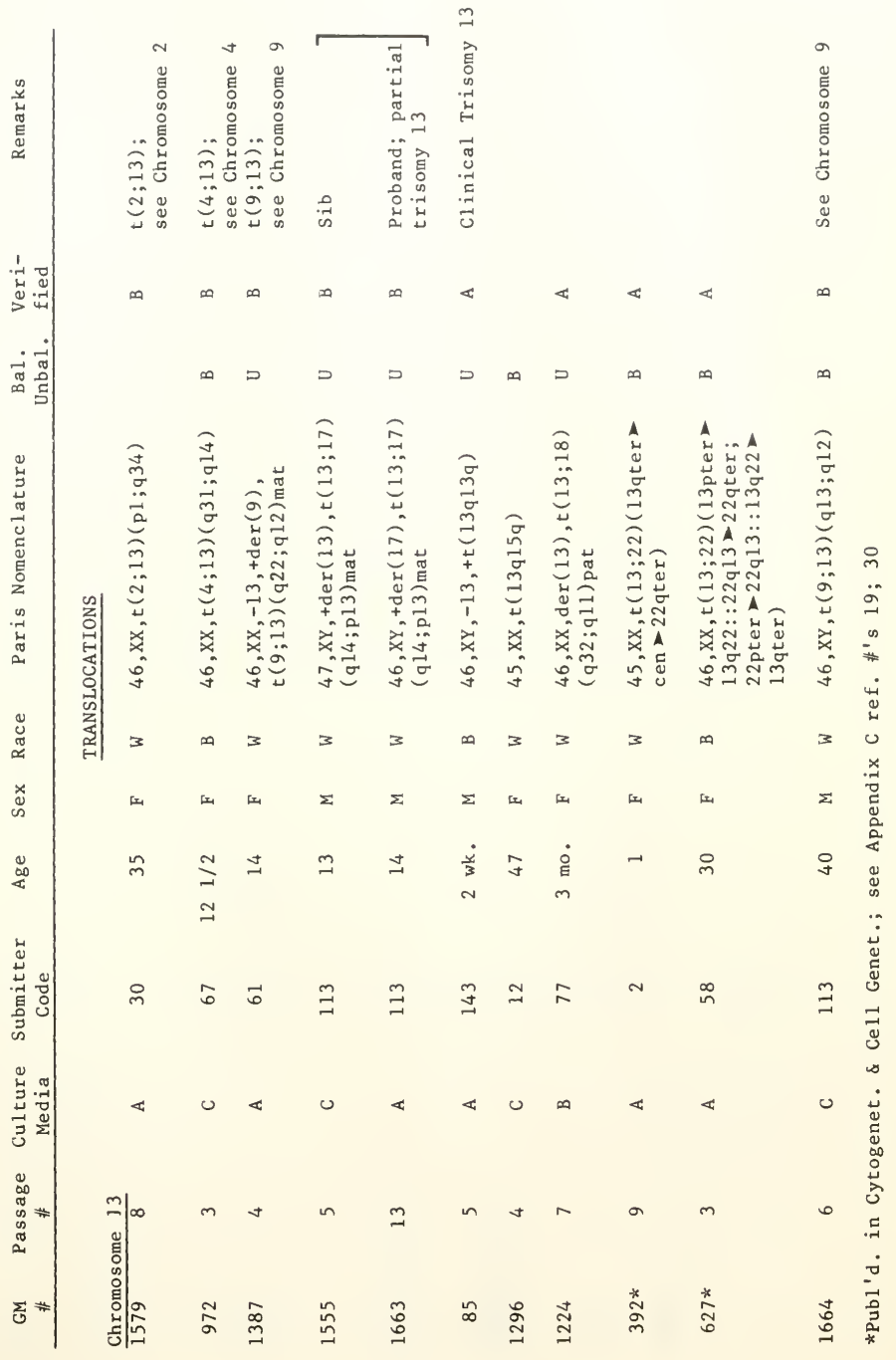




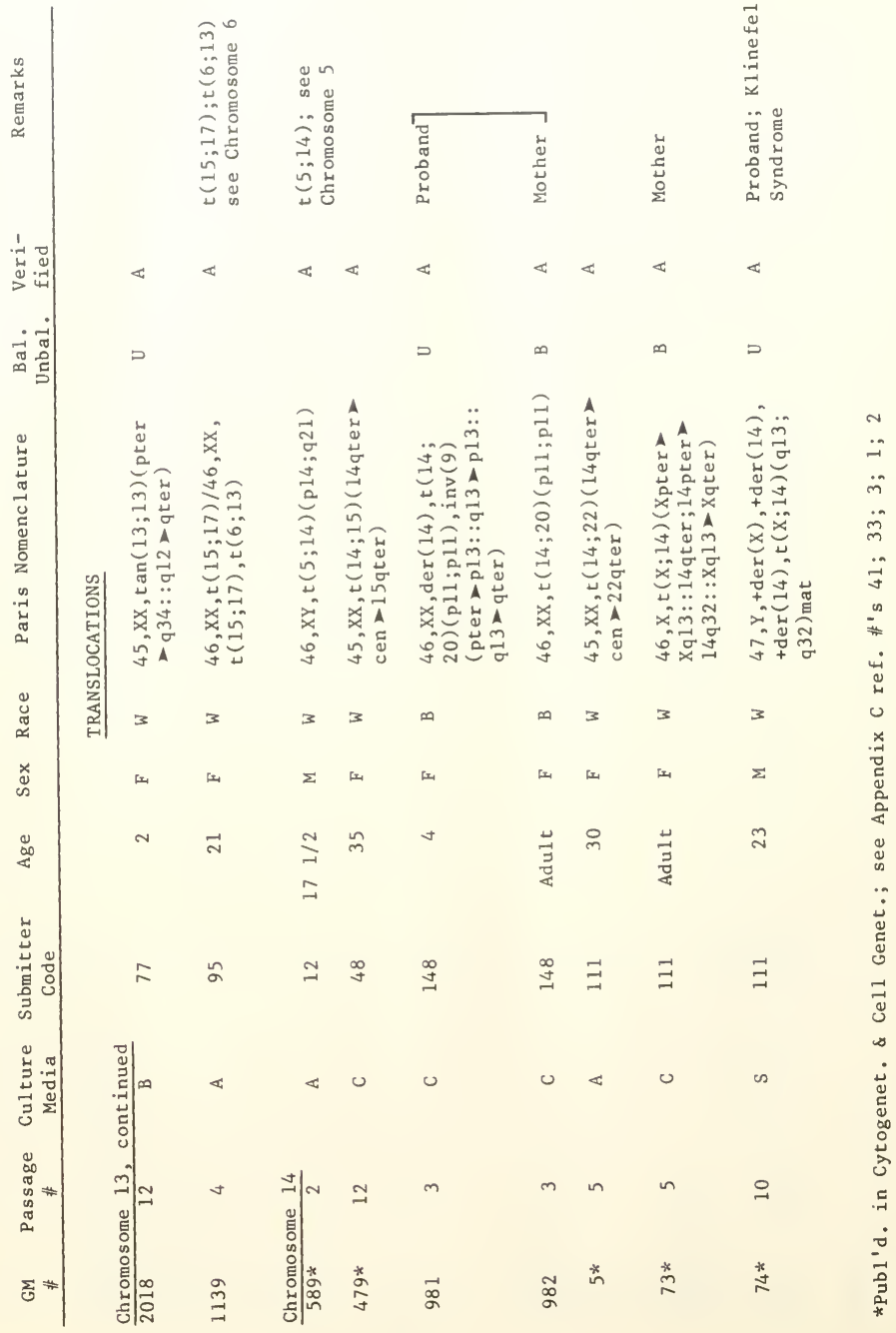




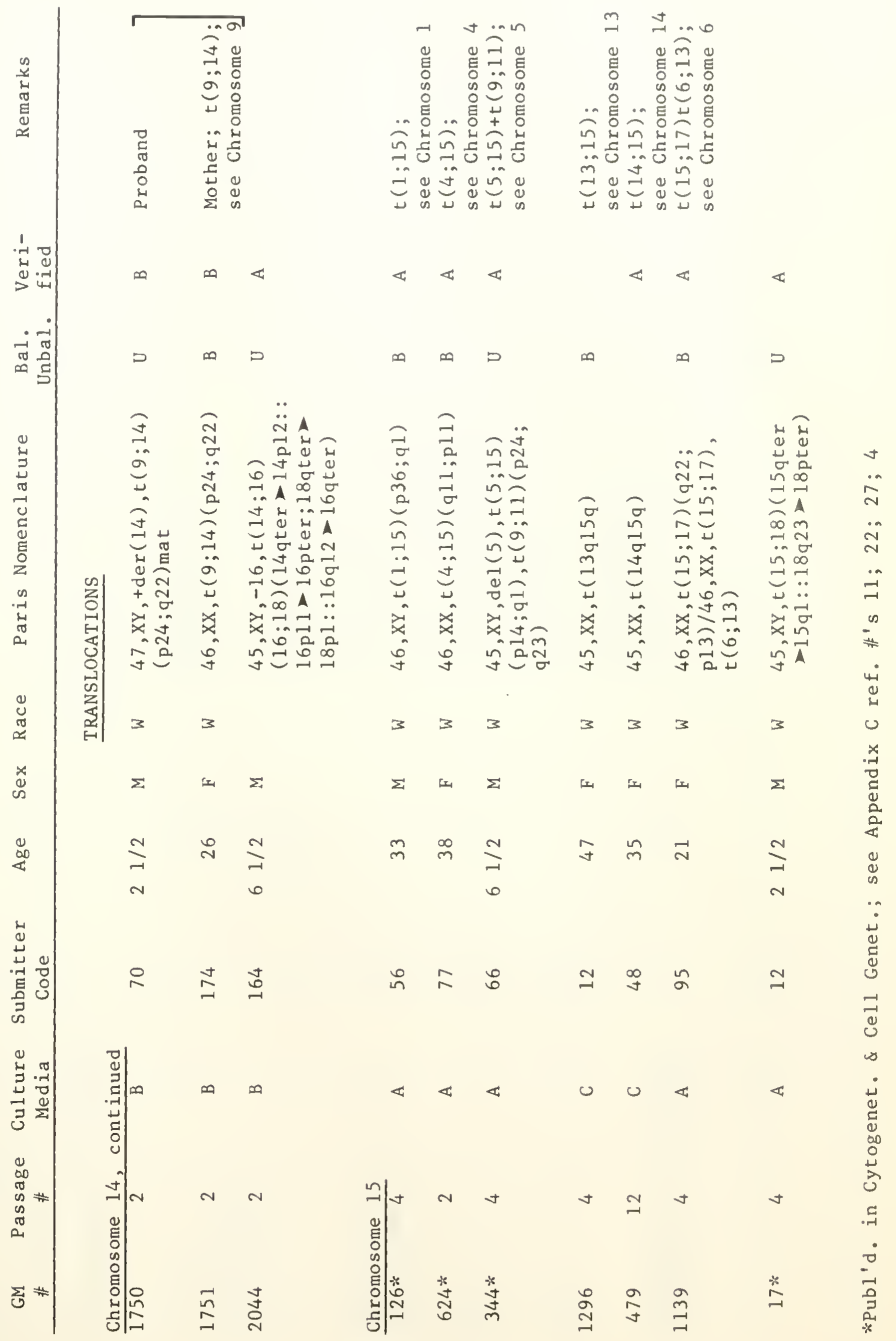




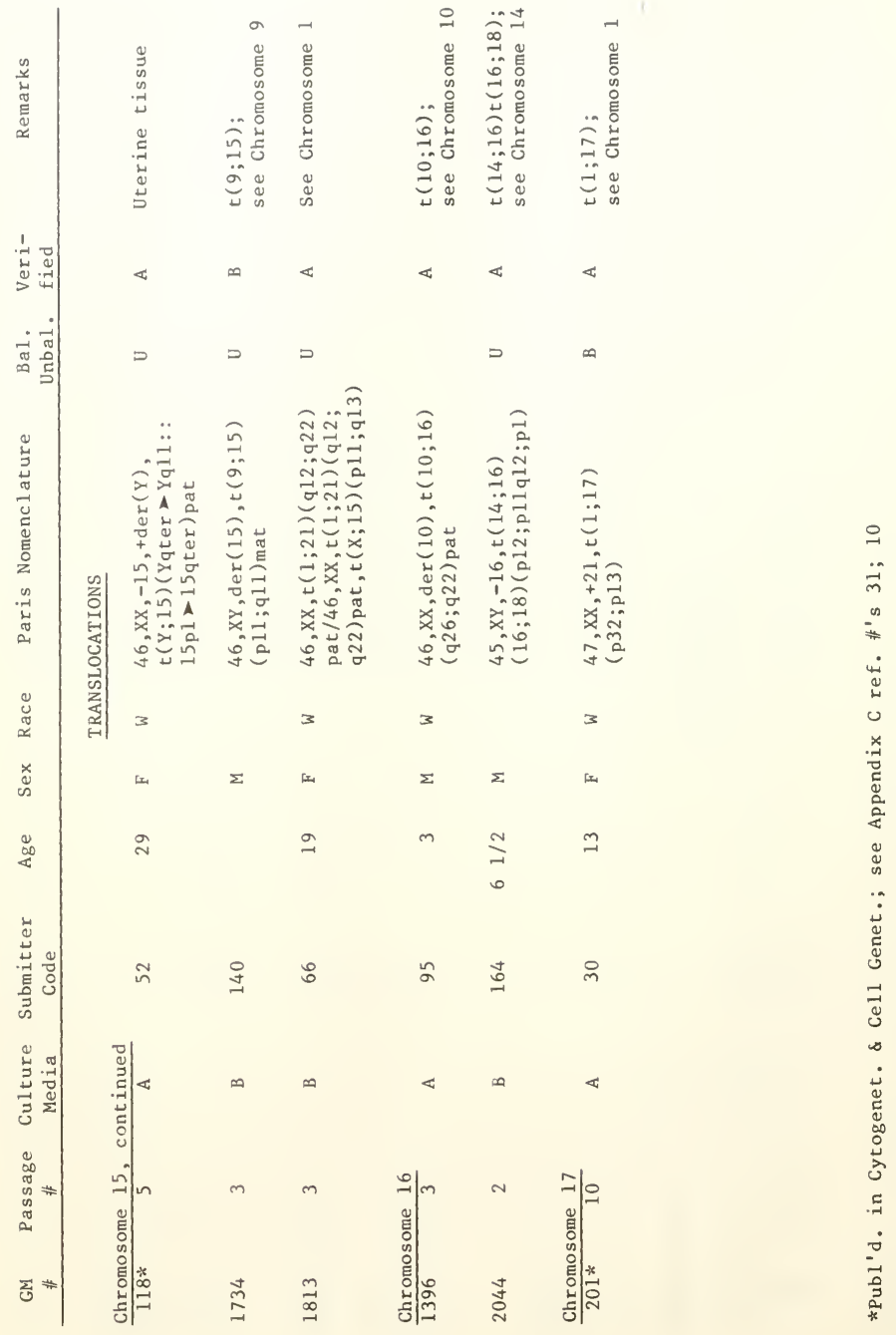




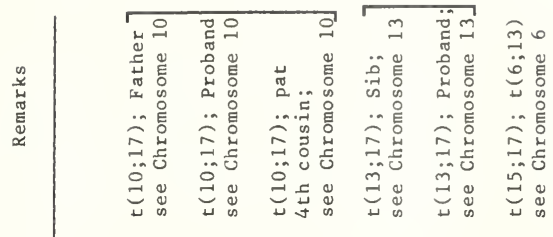

㟧

กิ

๑ $\square$

$\square$ m

$\infty$

$\sum_{0 \mid}^{\infty}$

กิ $\stackrel{\sim}{\pi}$

$\overparen{R}$

I

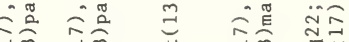

$\Rightarrow m$ $\Rightarrow$ च

華岂

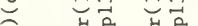

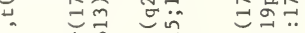

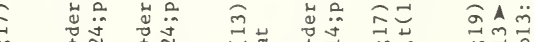

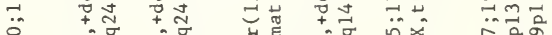

으

듀

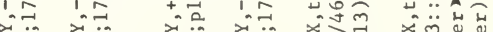

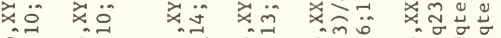
ĩ

$\stackrel{x}{\leftrightarrow}$

$\Sigma$

3

3

o

$\Sigma$

$\Sigma$

3

33

3

$\stackrel{\infty}{<}$

1

站㻤

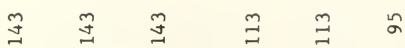

$\stackrel{\infty}{\text { in }}$

$\stackrel{\infty}{v}$

$\stackrel{*}{*}$

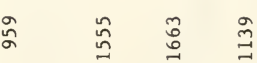

$\frac{*}{N}$ 
๘

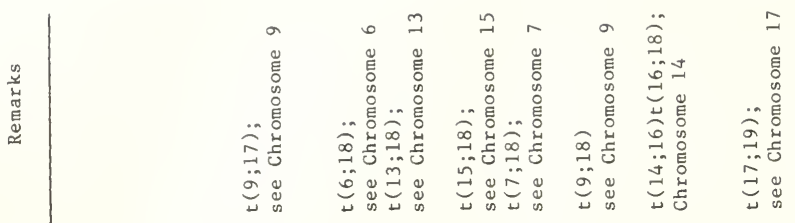

${ }_{0}^{1}$

(1)

4

$\infty$

ص

岁

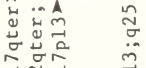

Nㅡㅁ.

(ิ)

든

프 न न

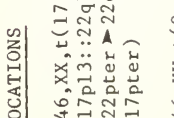

ä

ษ

$\underset{凶}{x}$

$\infty_{4}^{\infty}$

$\frac{\dot{x}}{3}$

$\infty \quad \square \quad \square$

$n$

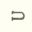

$\infty$

3

3

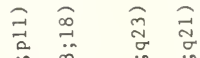

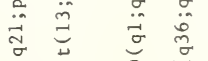

$\stackrel{2}{a}$

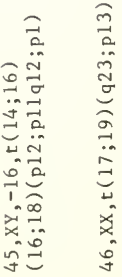

$\cong$

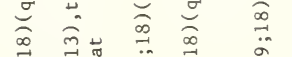

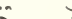

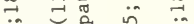

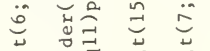

x

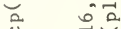

u.

x $\quad$ in

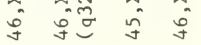

ำ

$\varangle$

33333

3

䓠

峞

岃

$\infty$

$\infty$

$\stackrel{N}{N}$ ก

$\stackrel{\infty}{\curvearrowleft}$

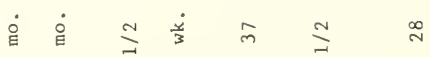

草

का

$\circlearrowleft$

$\varangle \infty \quad \infty \quad \infty \quad \infty \quad \varangle$

उु

0
$\infty$
0
0
0
$\infty$
$\infty$
0

$\stackrel{ }{\longrightarrow}$

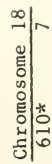

$n+m$
$\stackrel{*}{N} \stackrel{*}{=}$ in

n
N
$\infty$

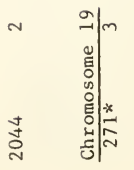

تే

.

.

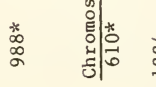




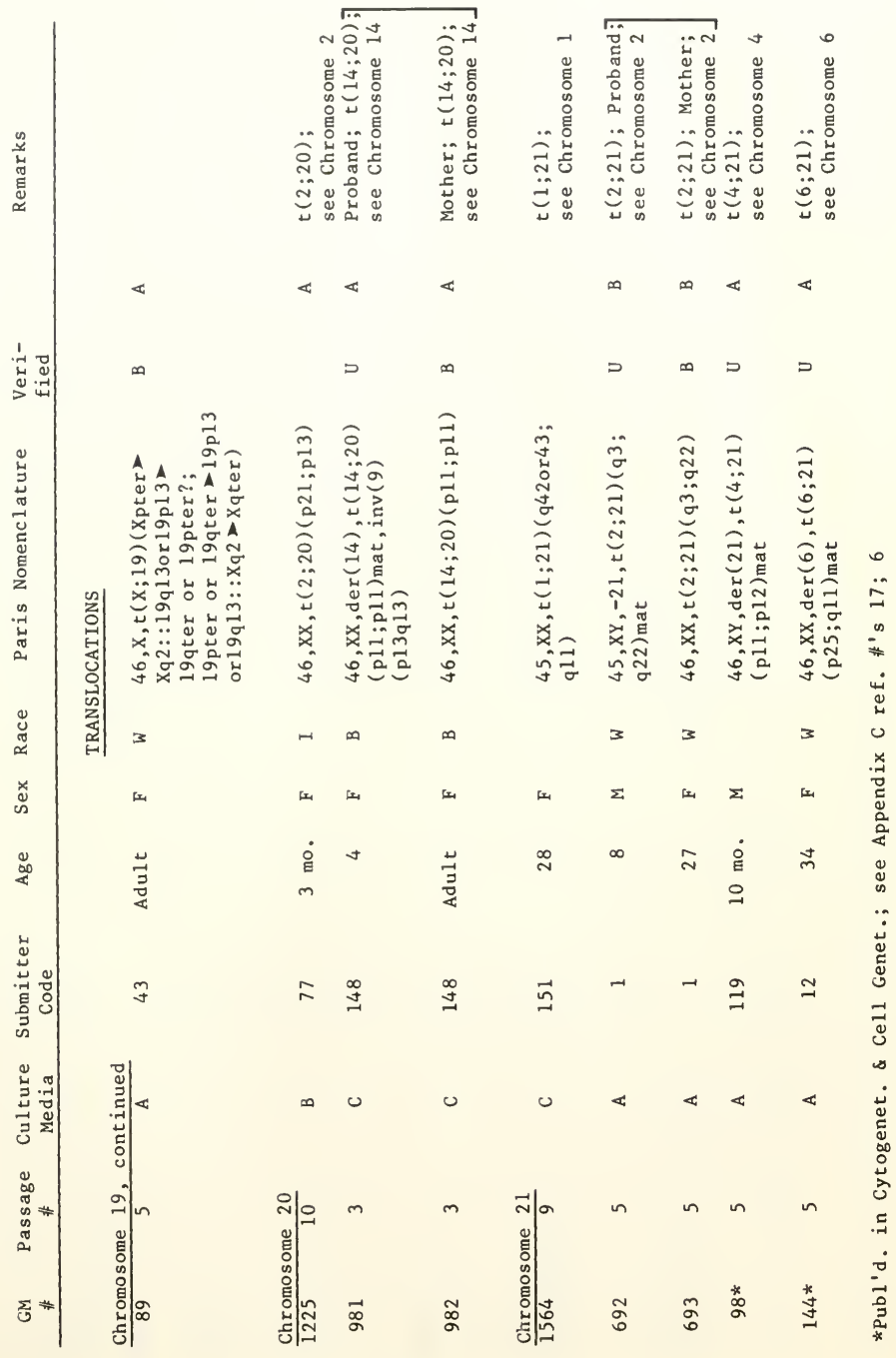




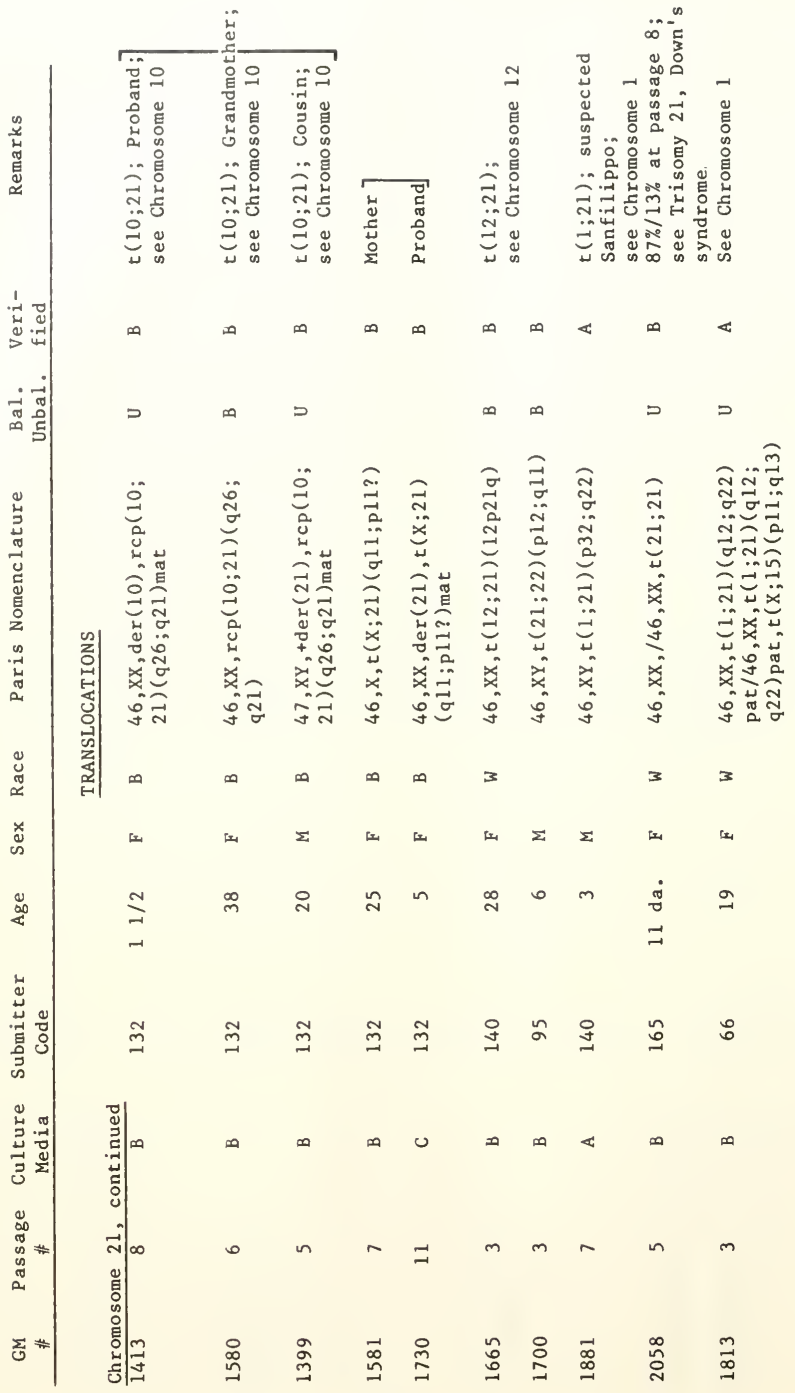




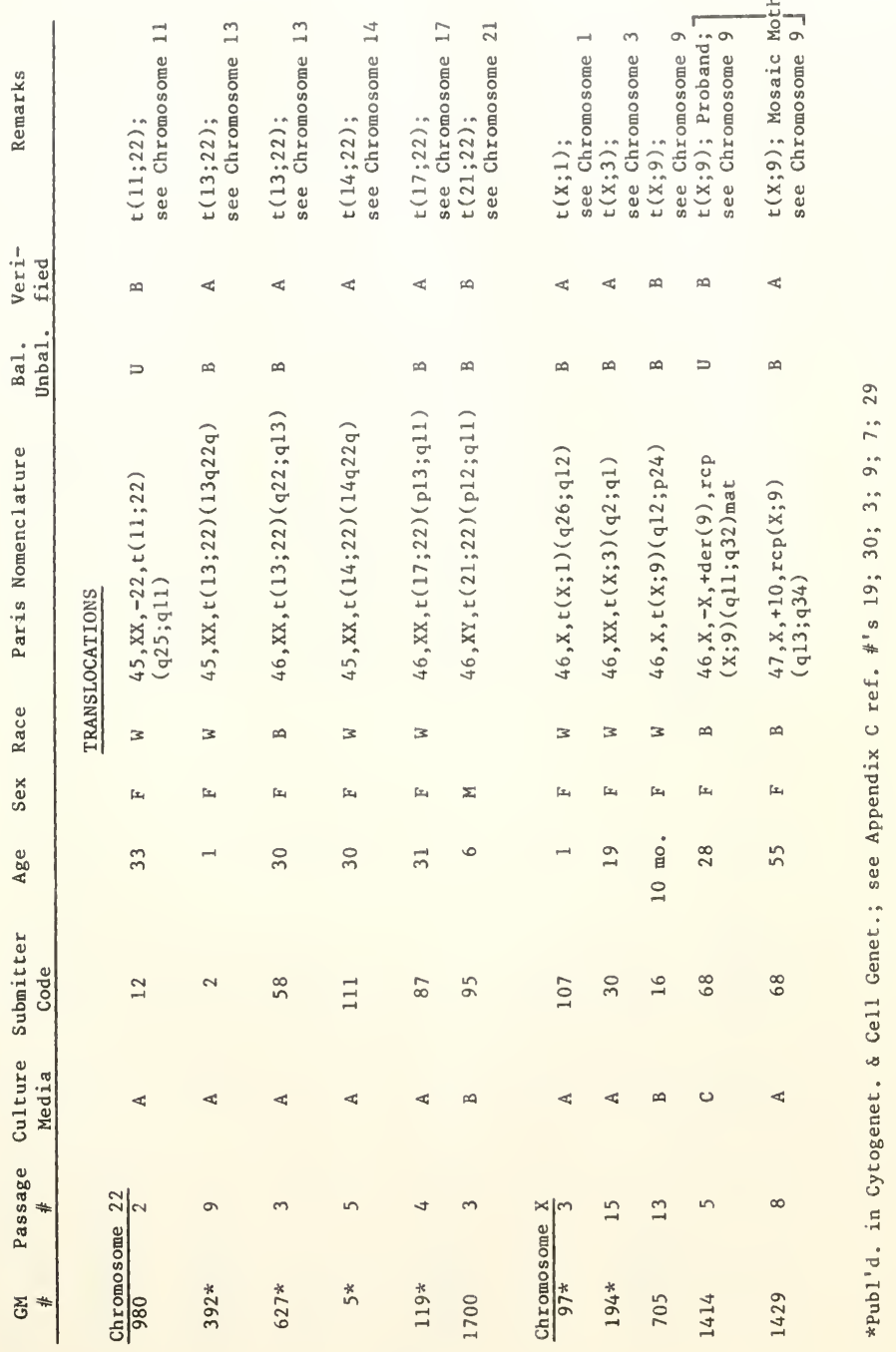




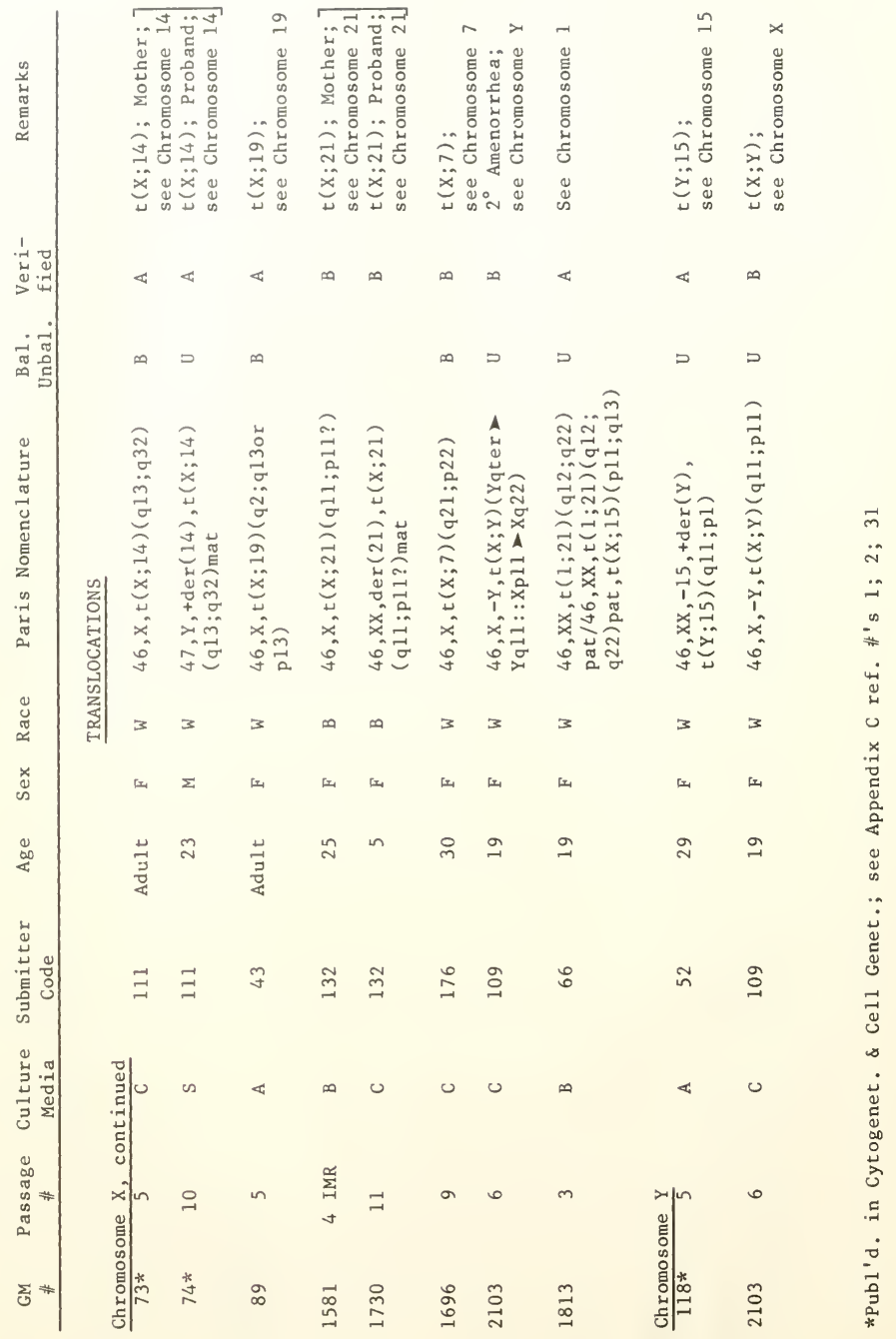




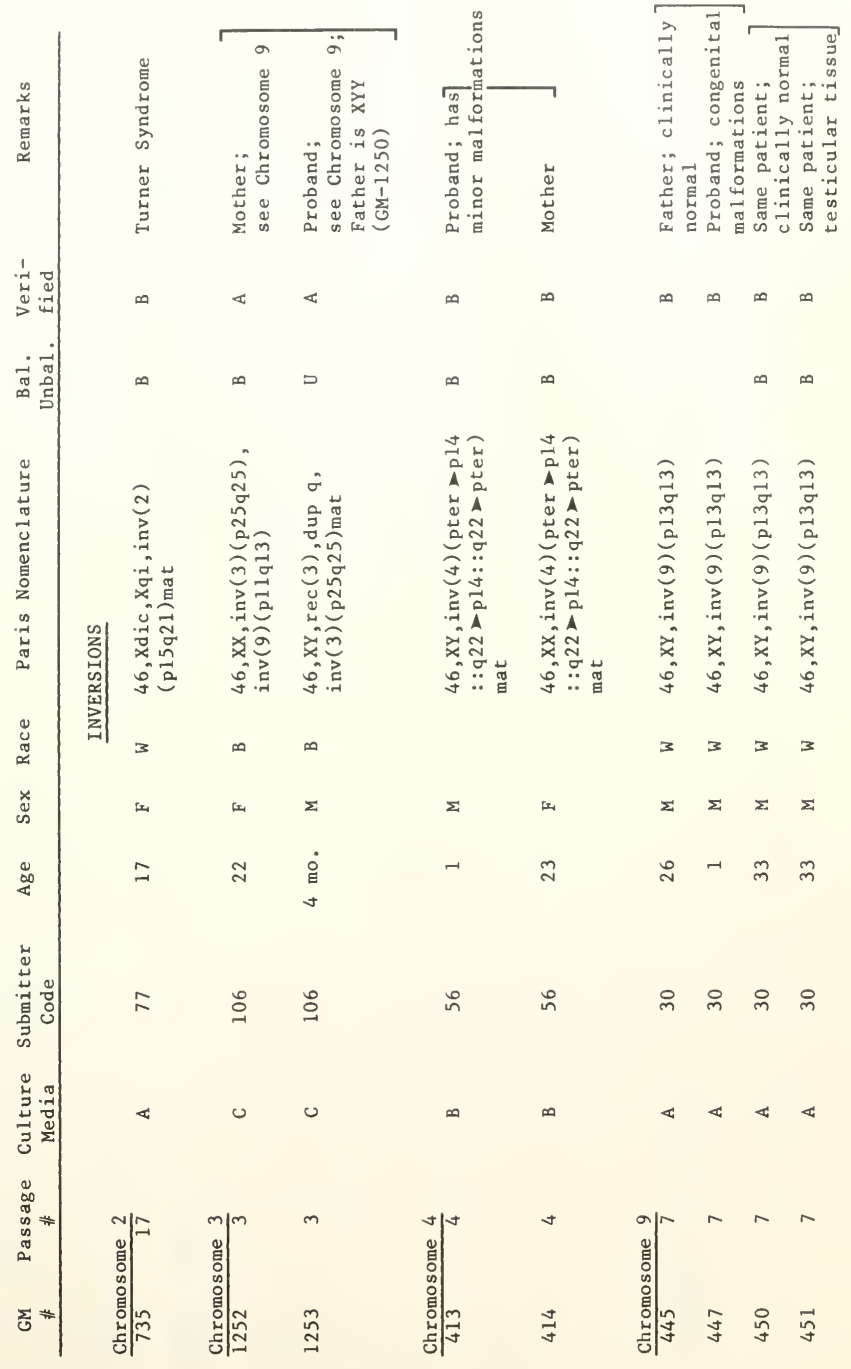




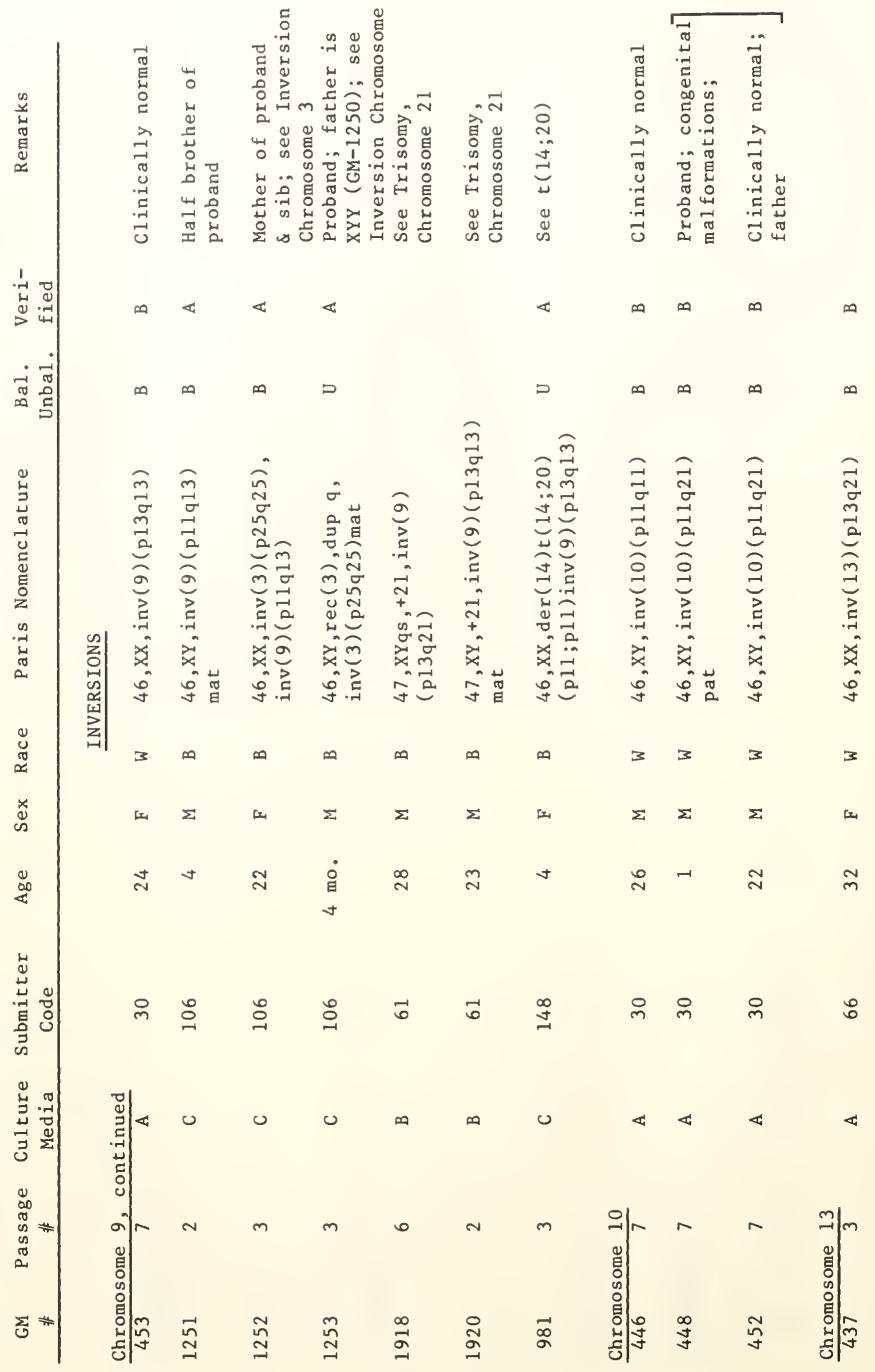




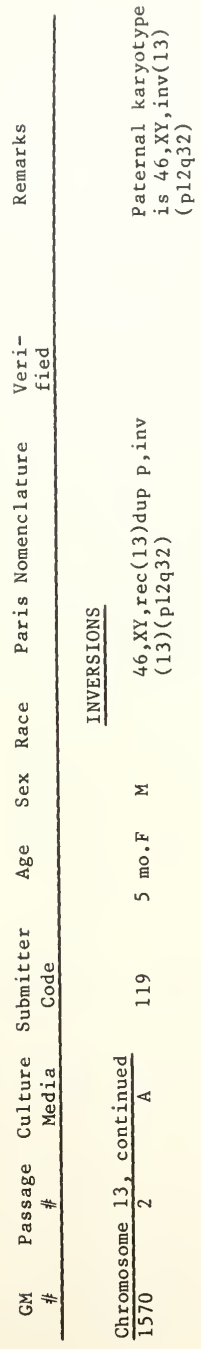




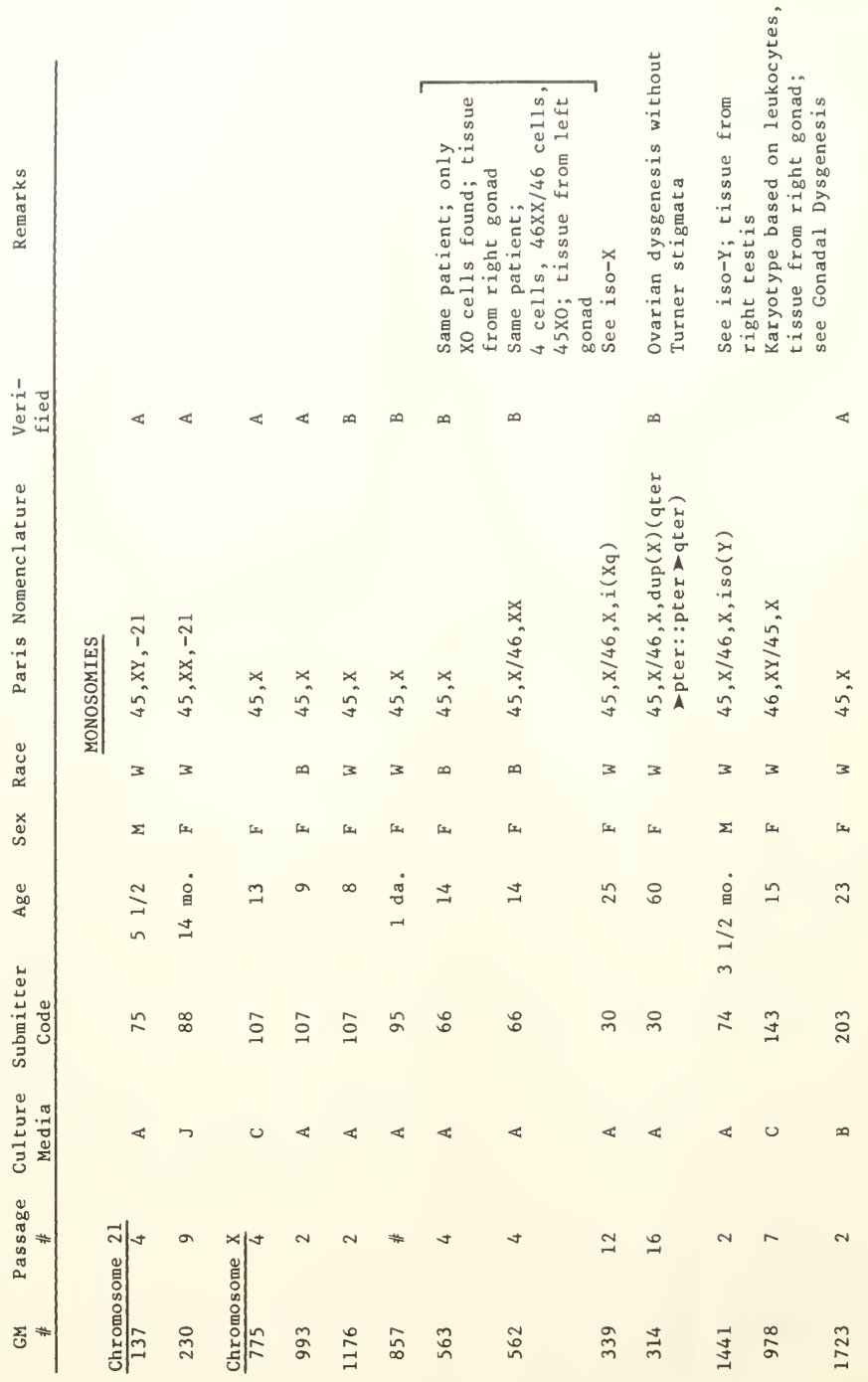




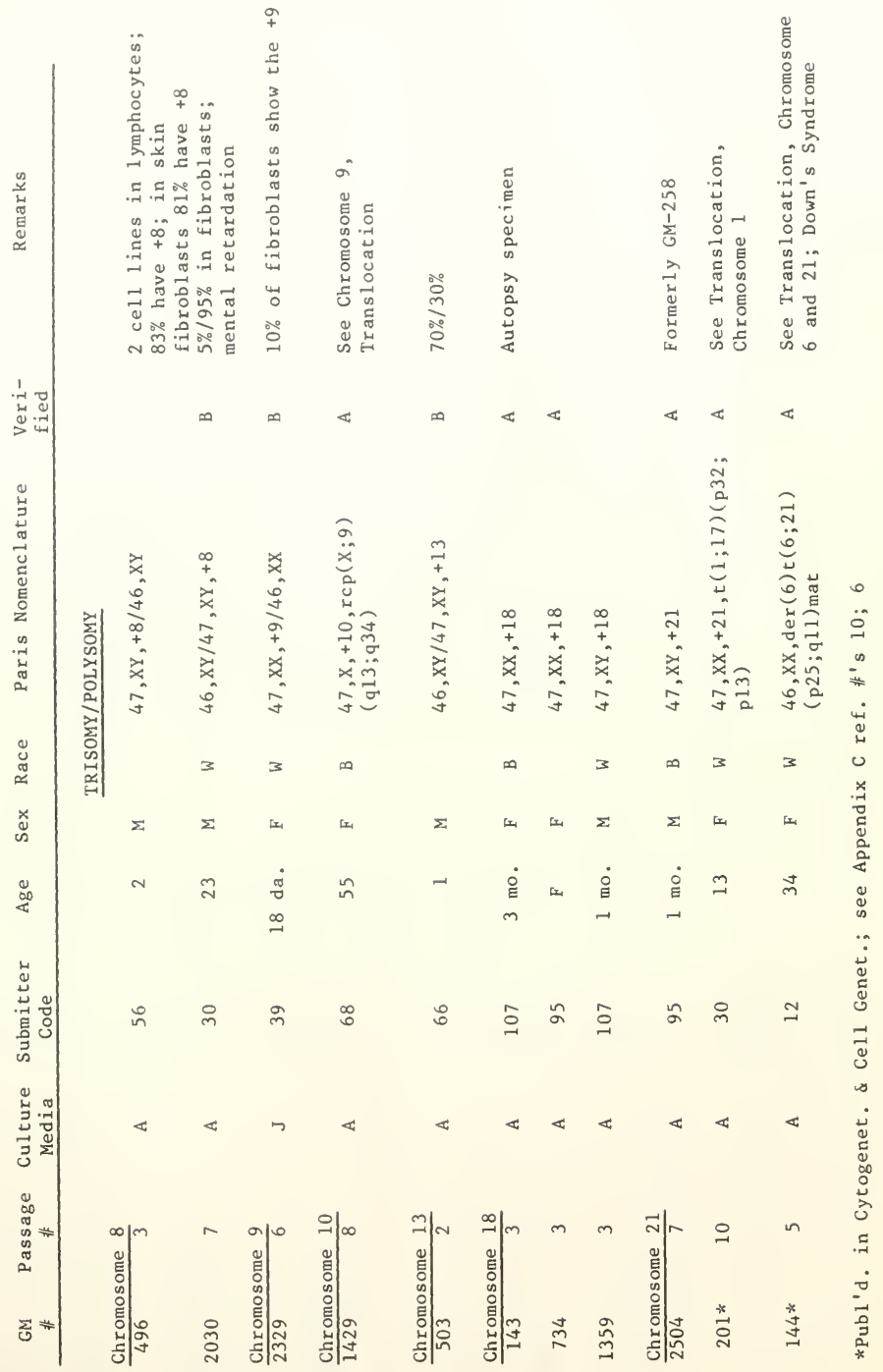




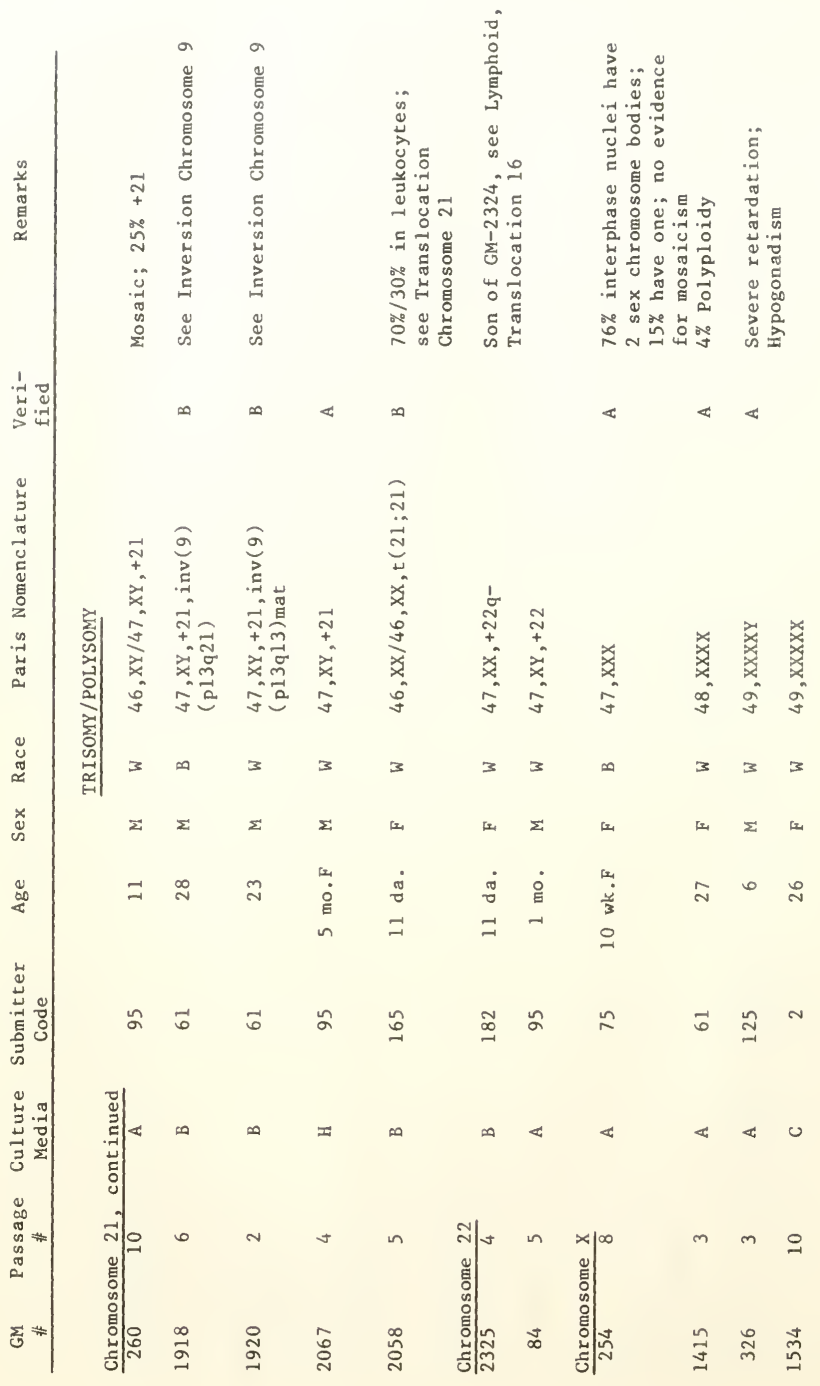




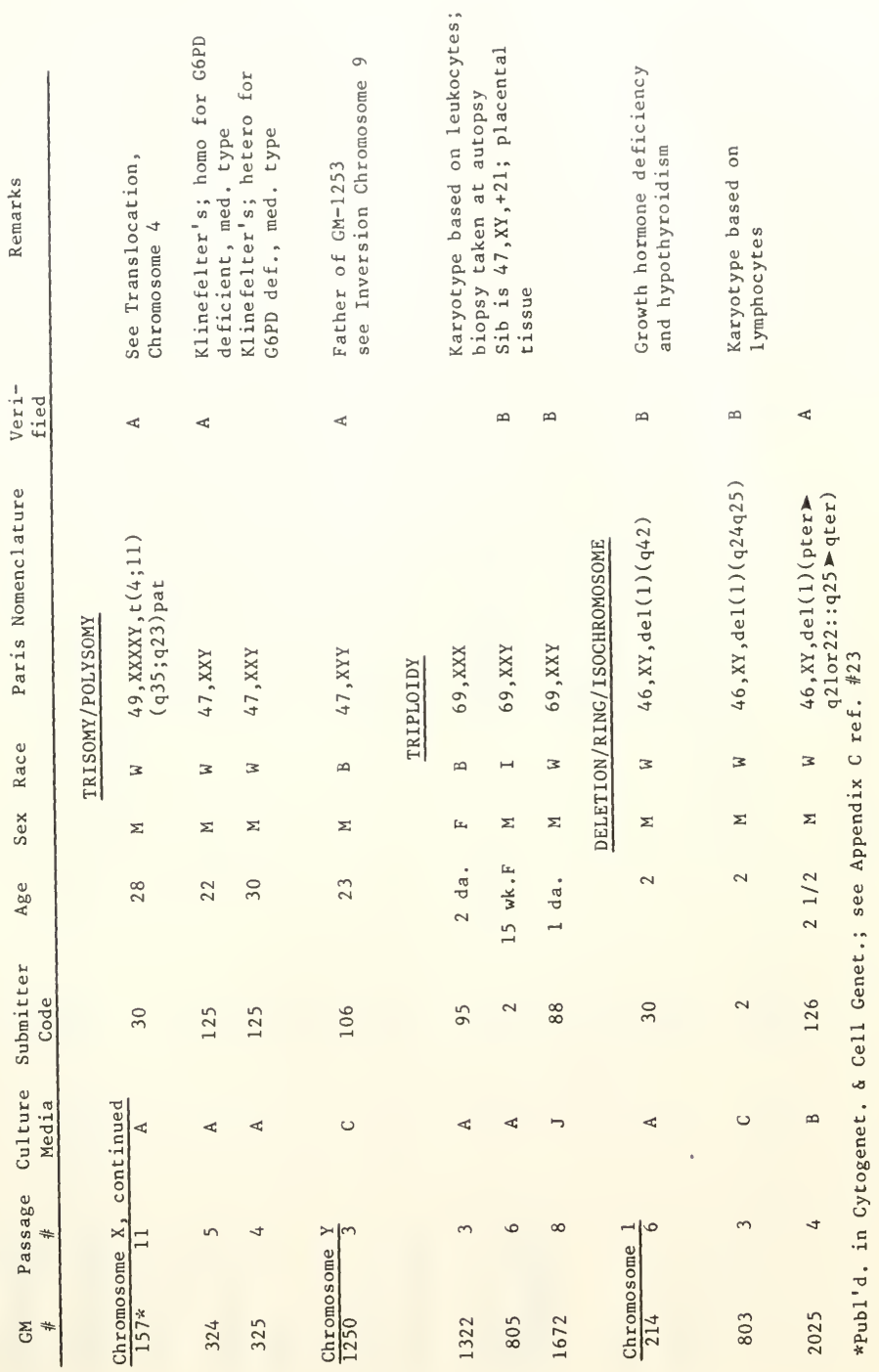




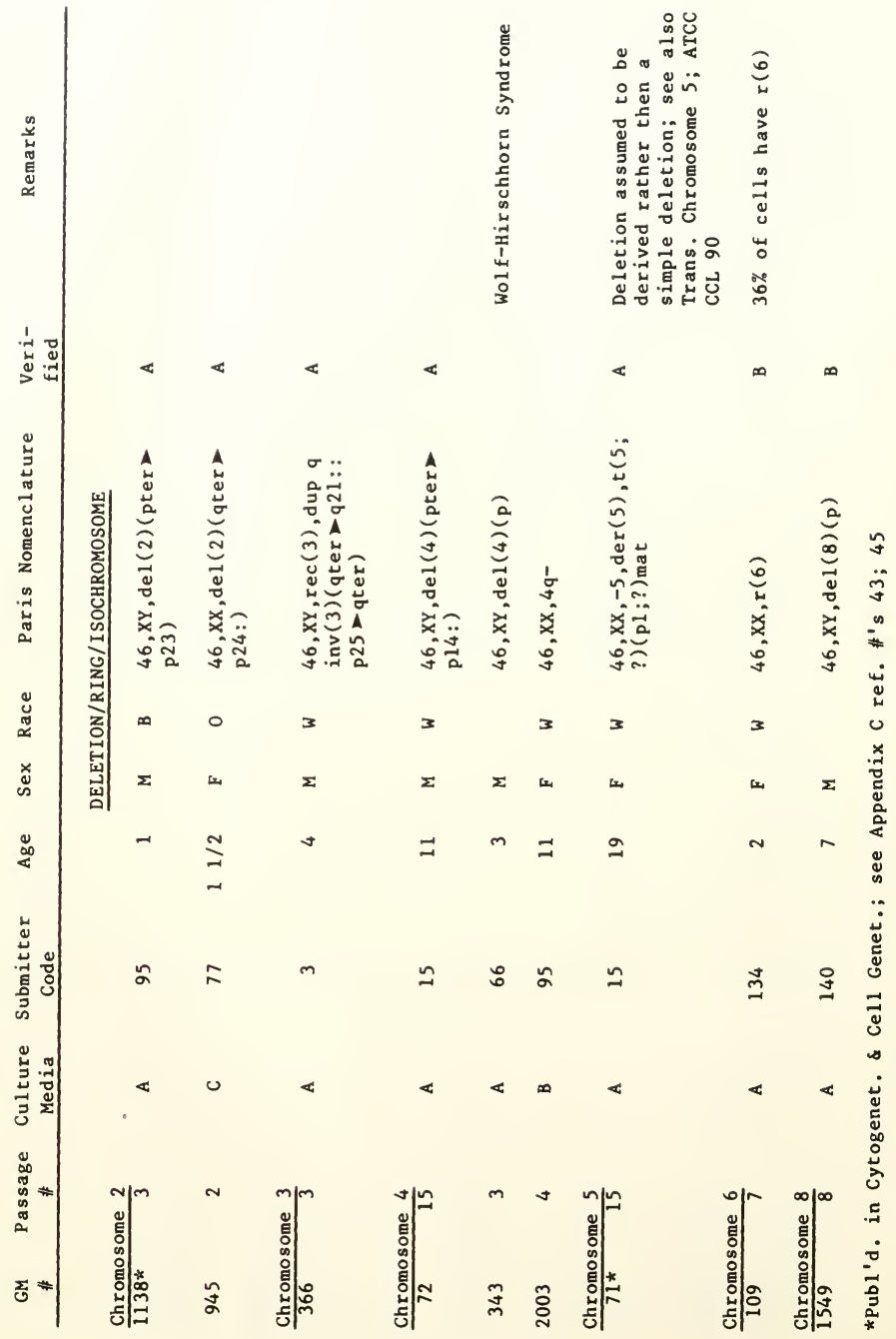




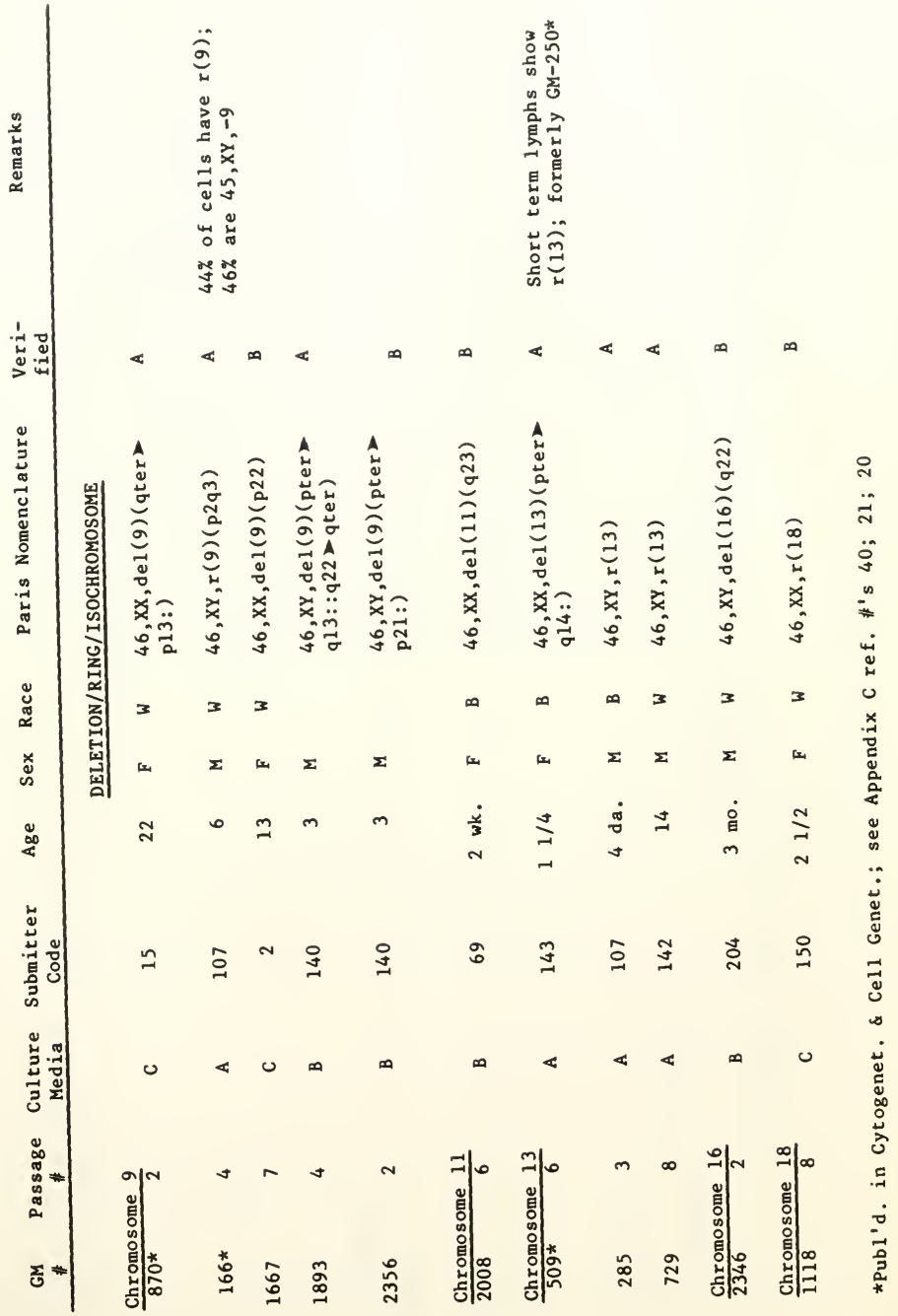




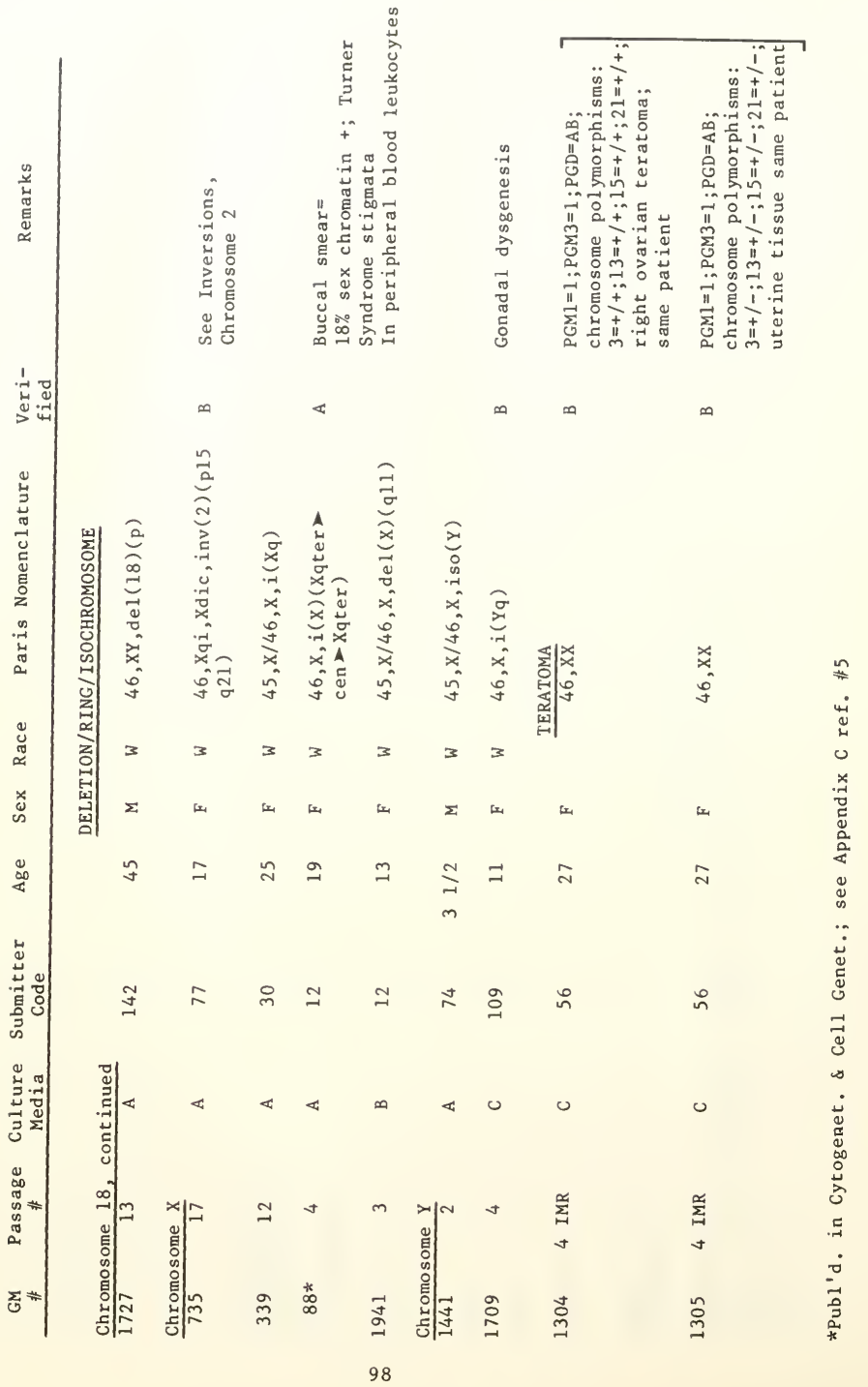




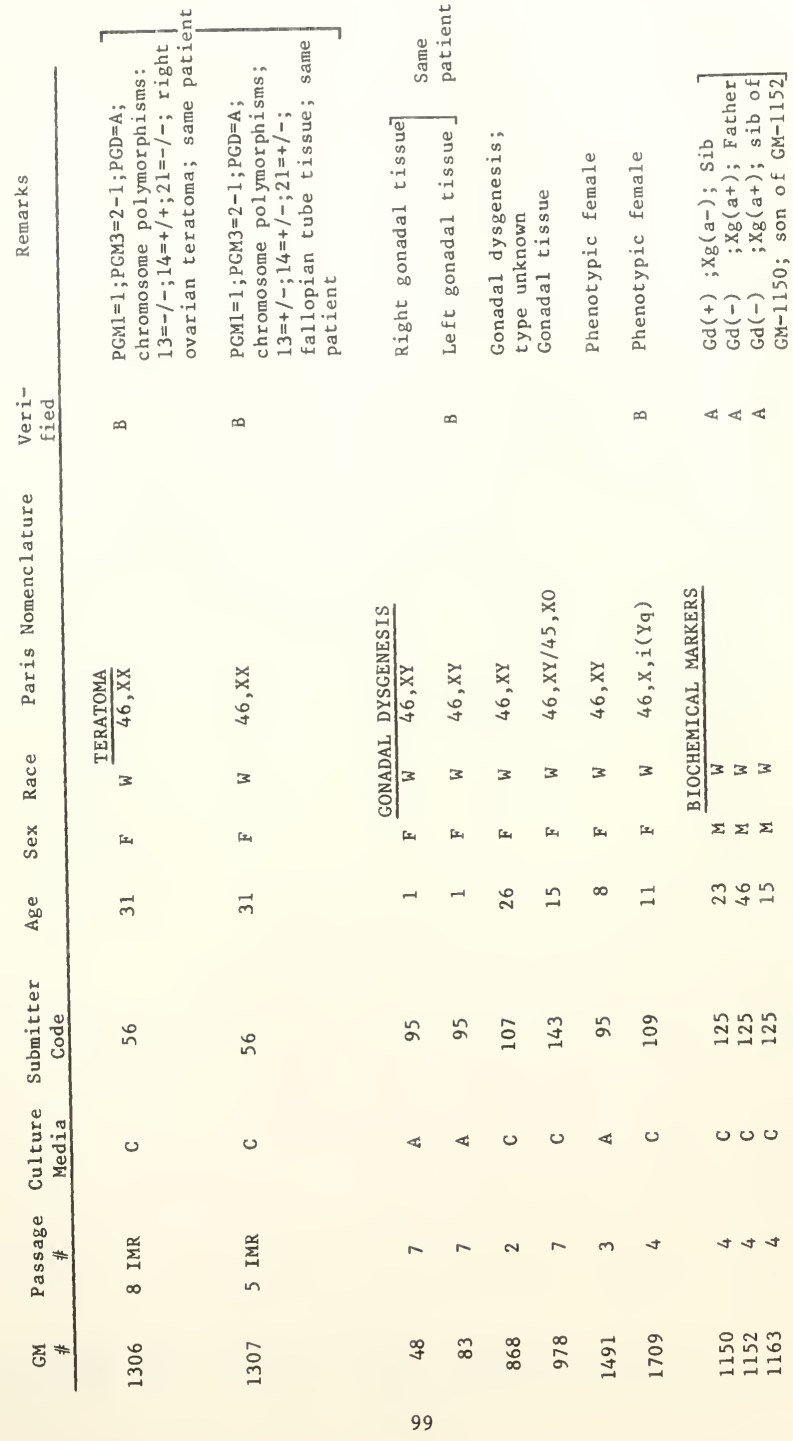




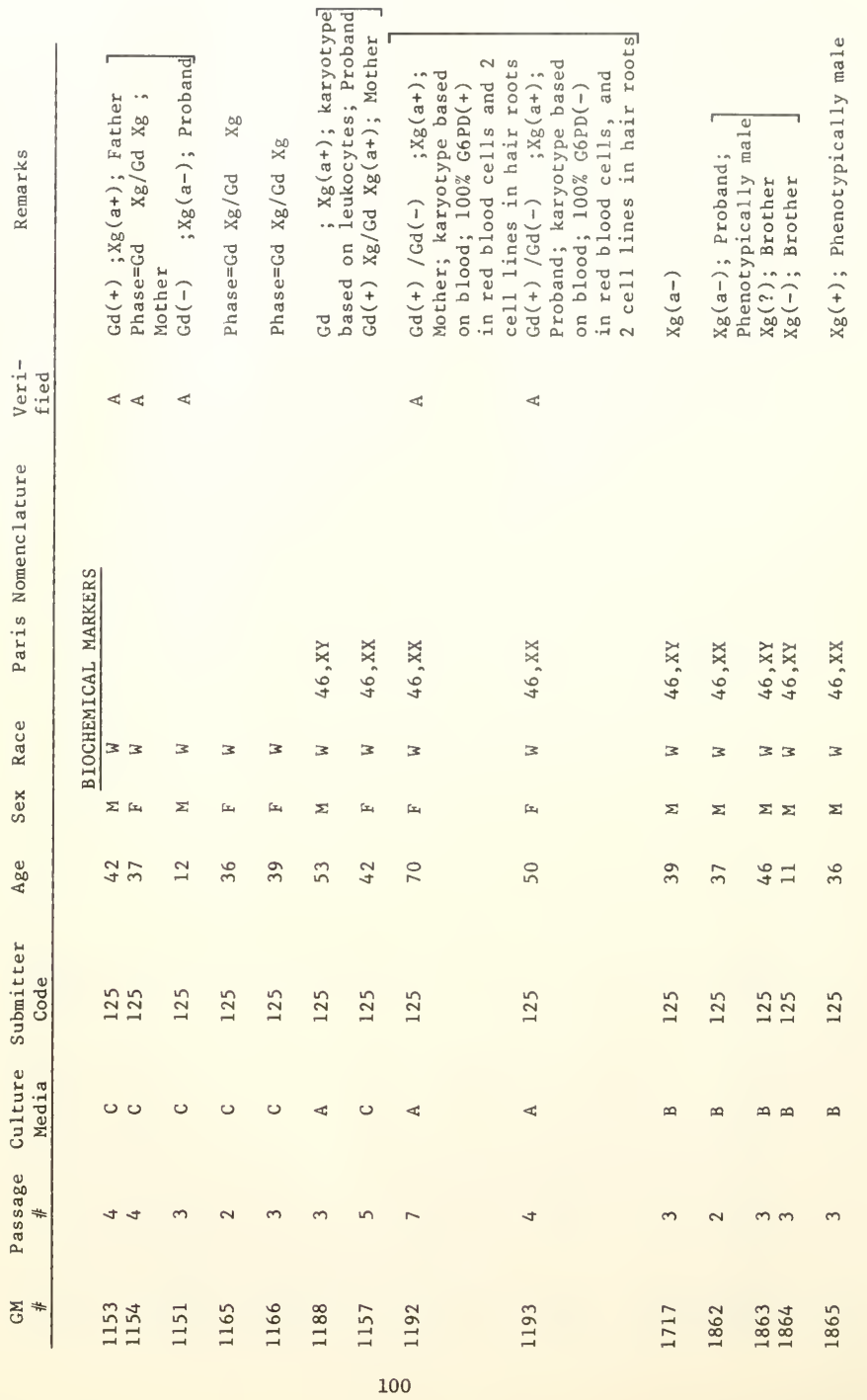




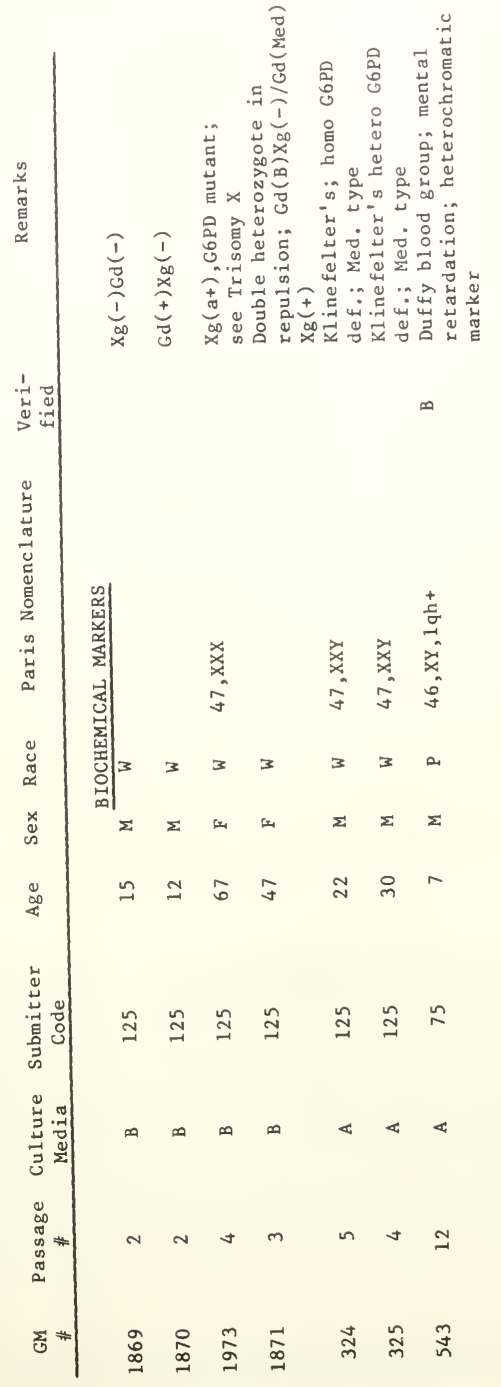




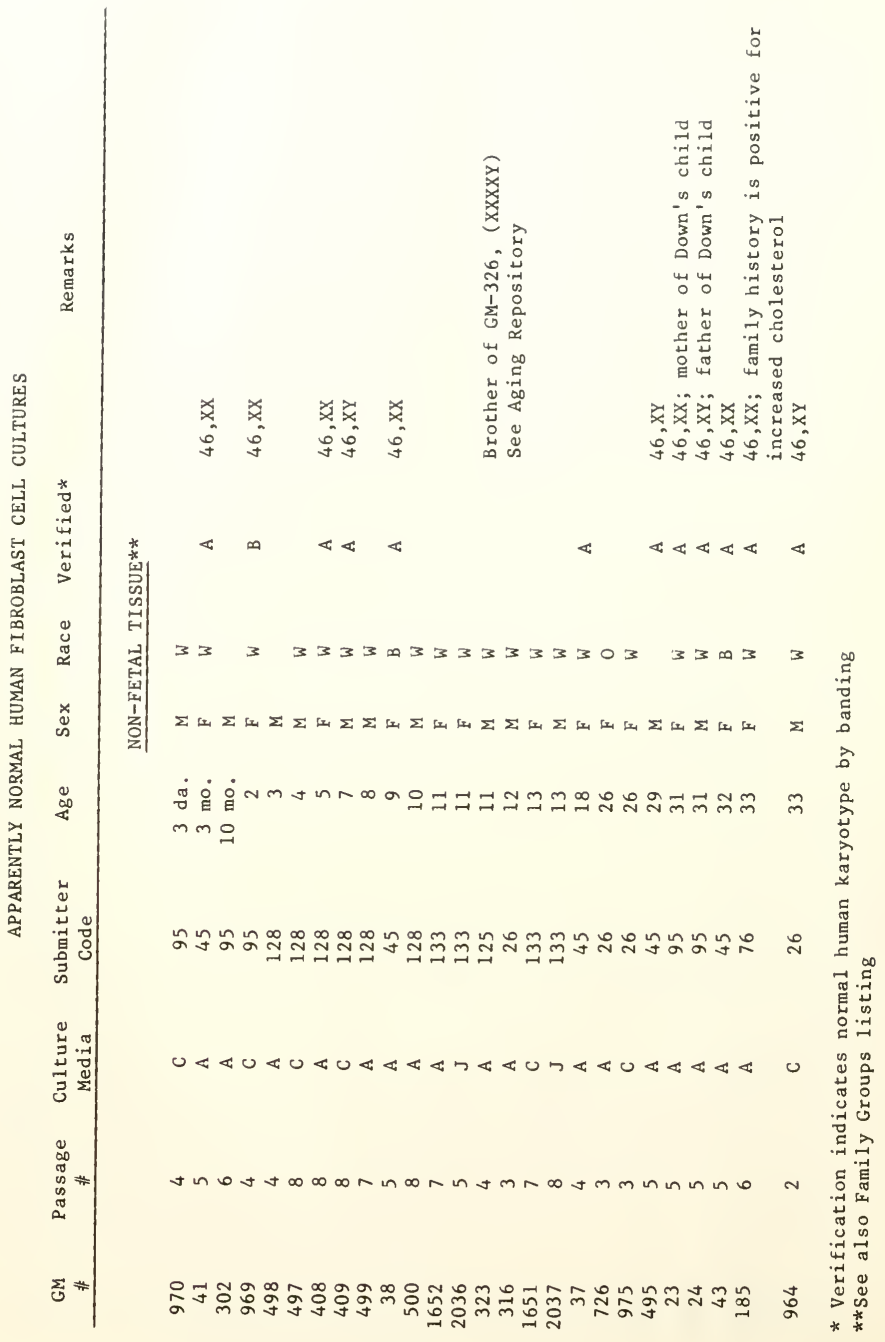




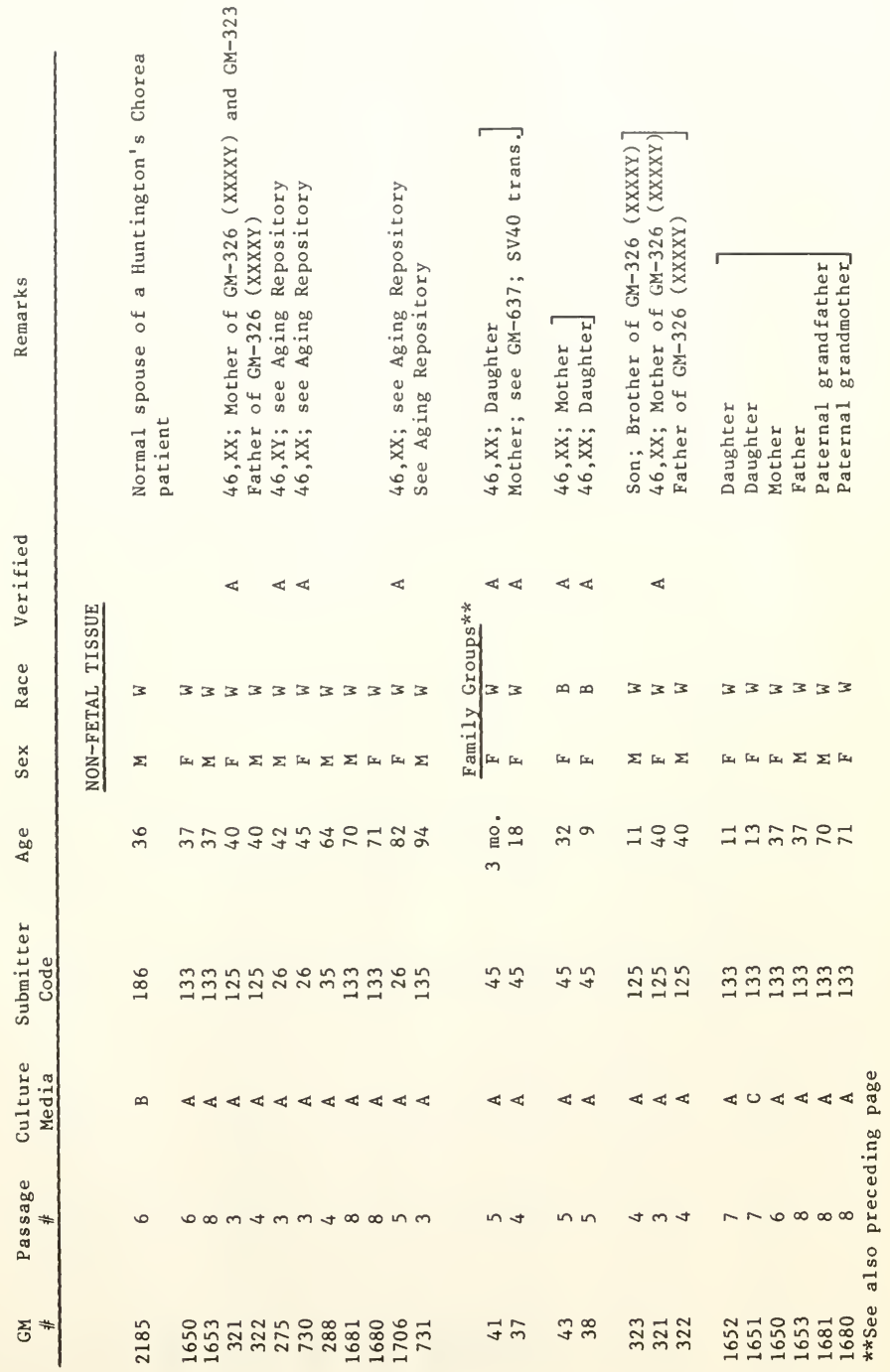




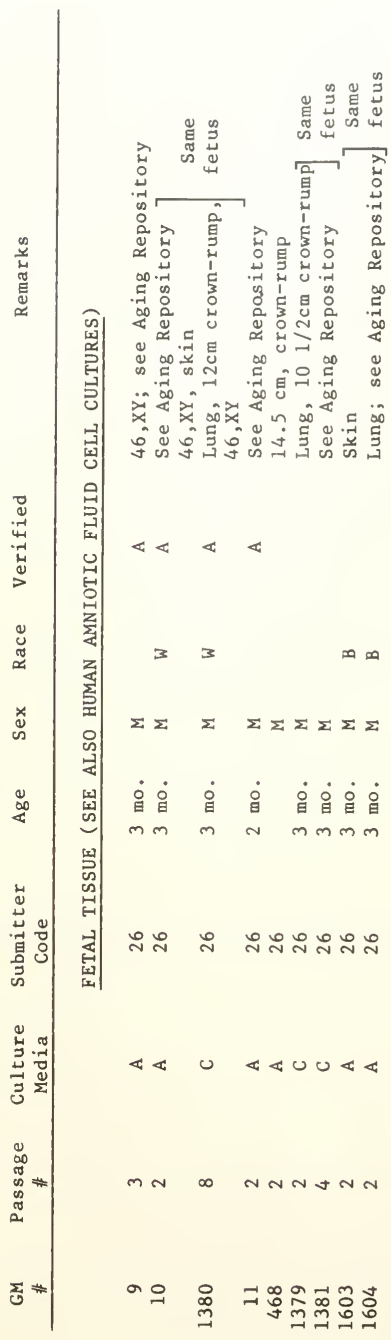




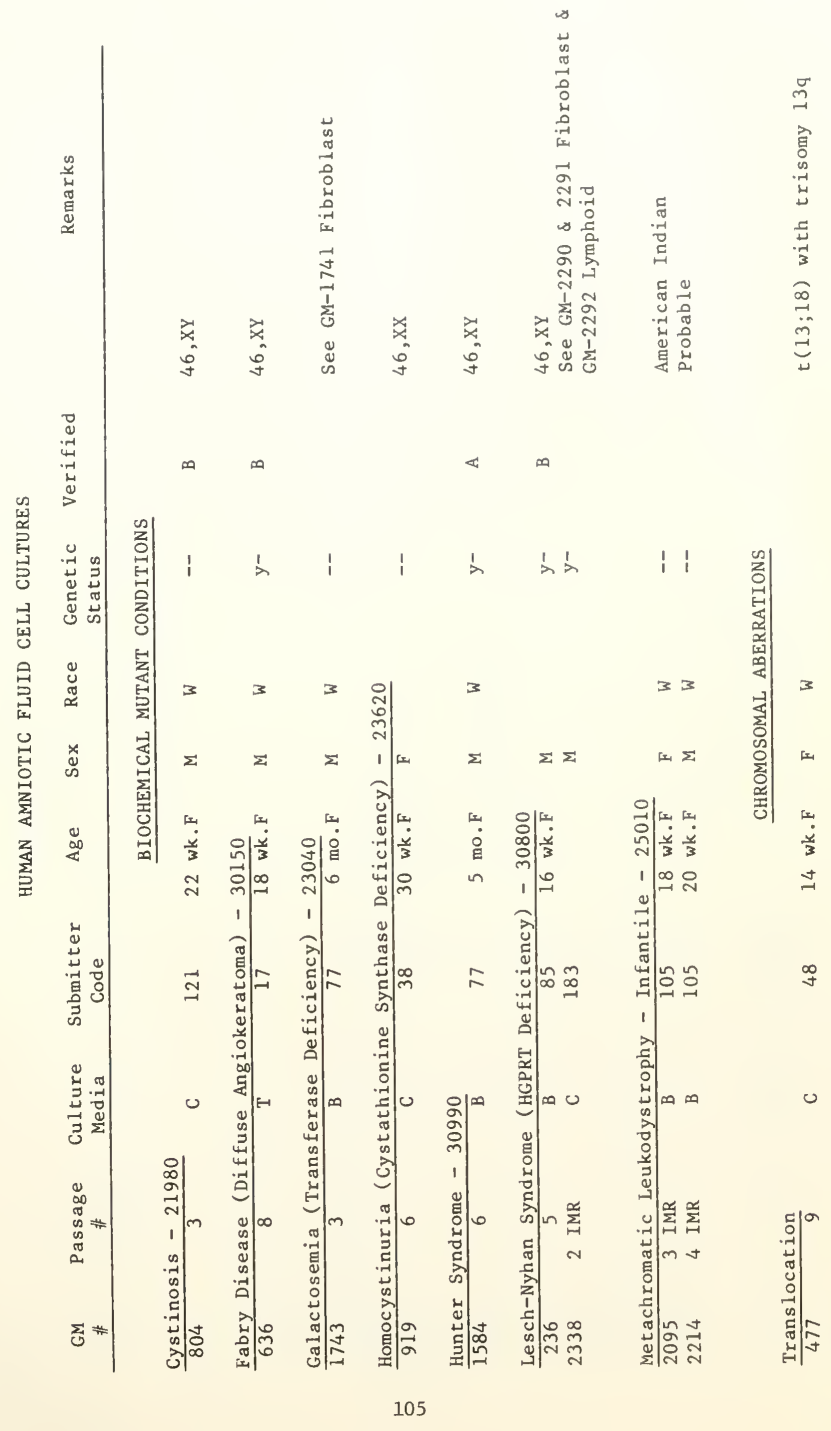




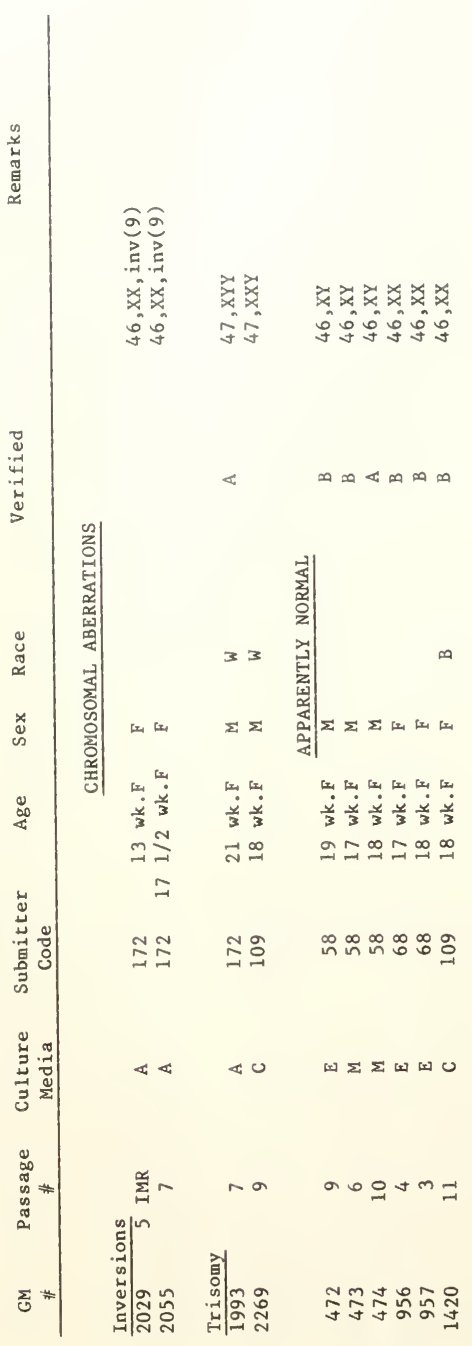



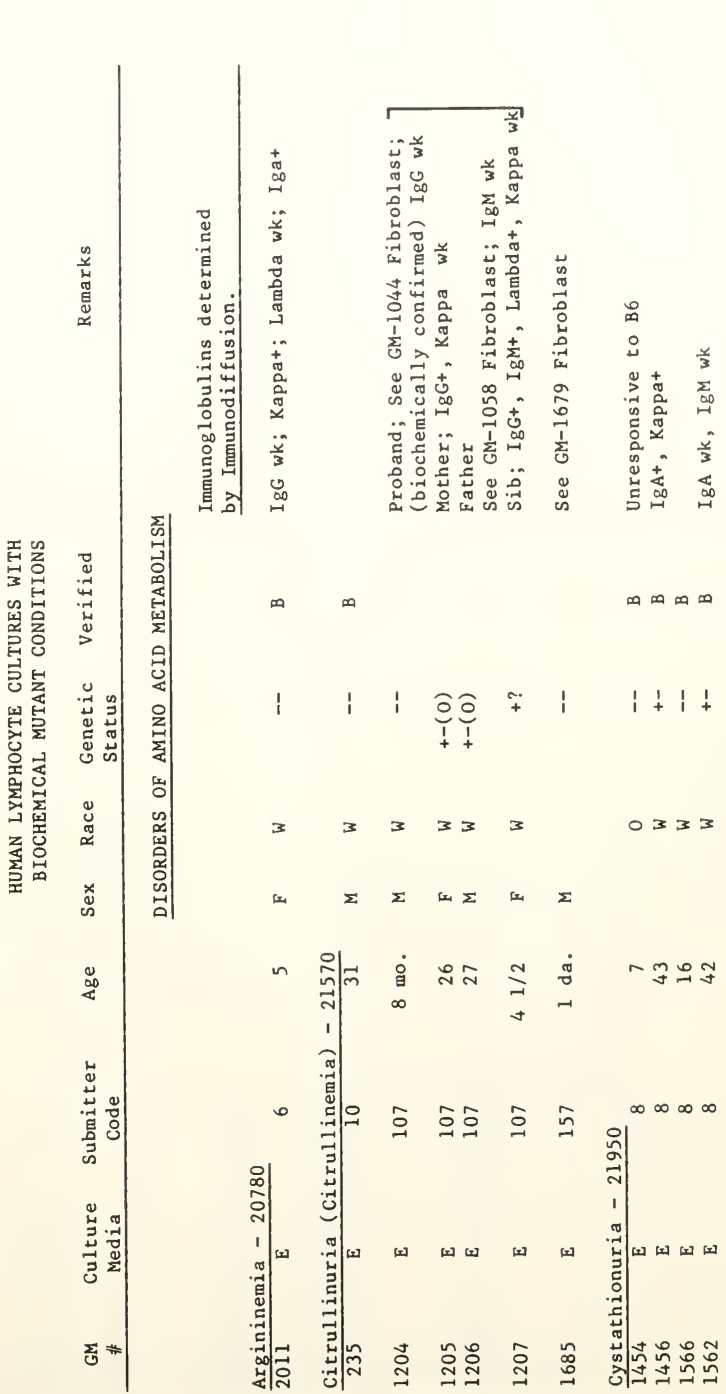

$\infty$

$\infty$

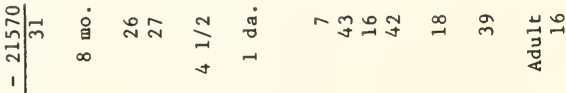

-

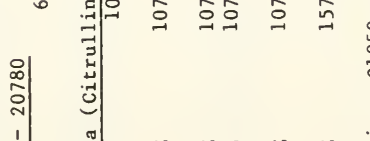
స్n 


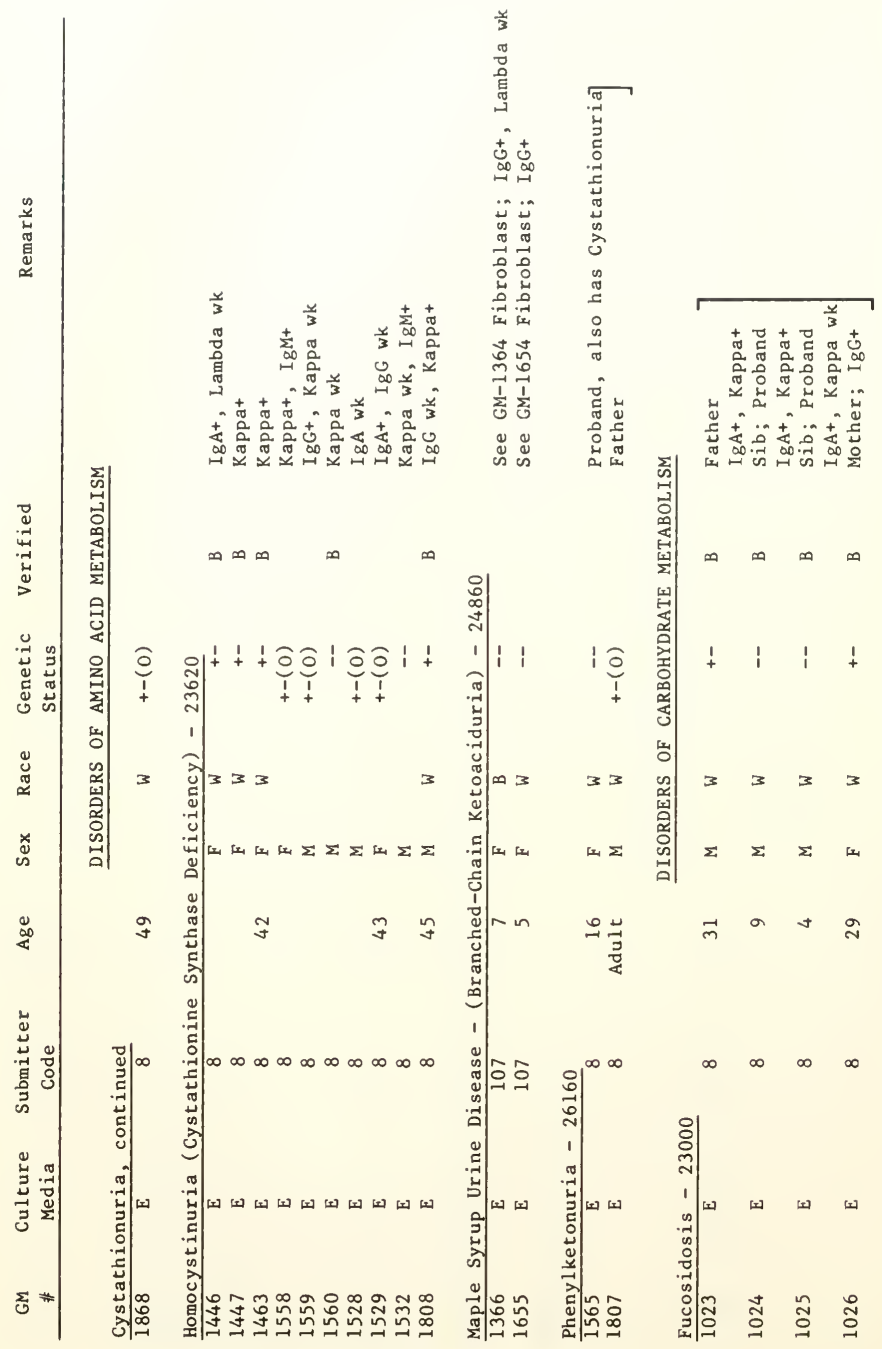




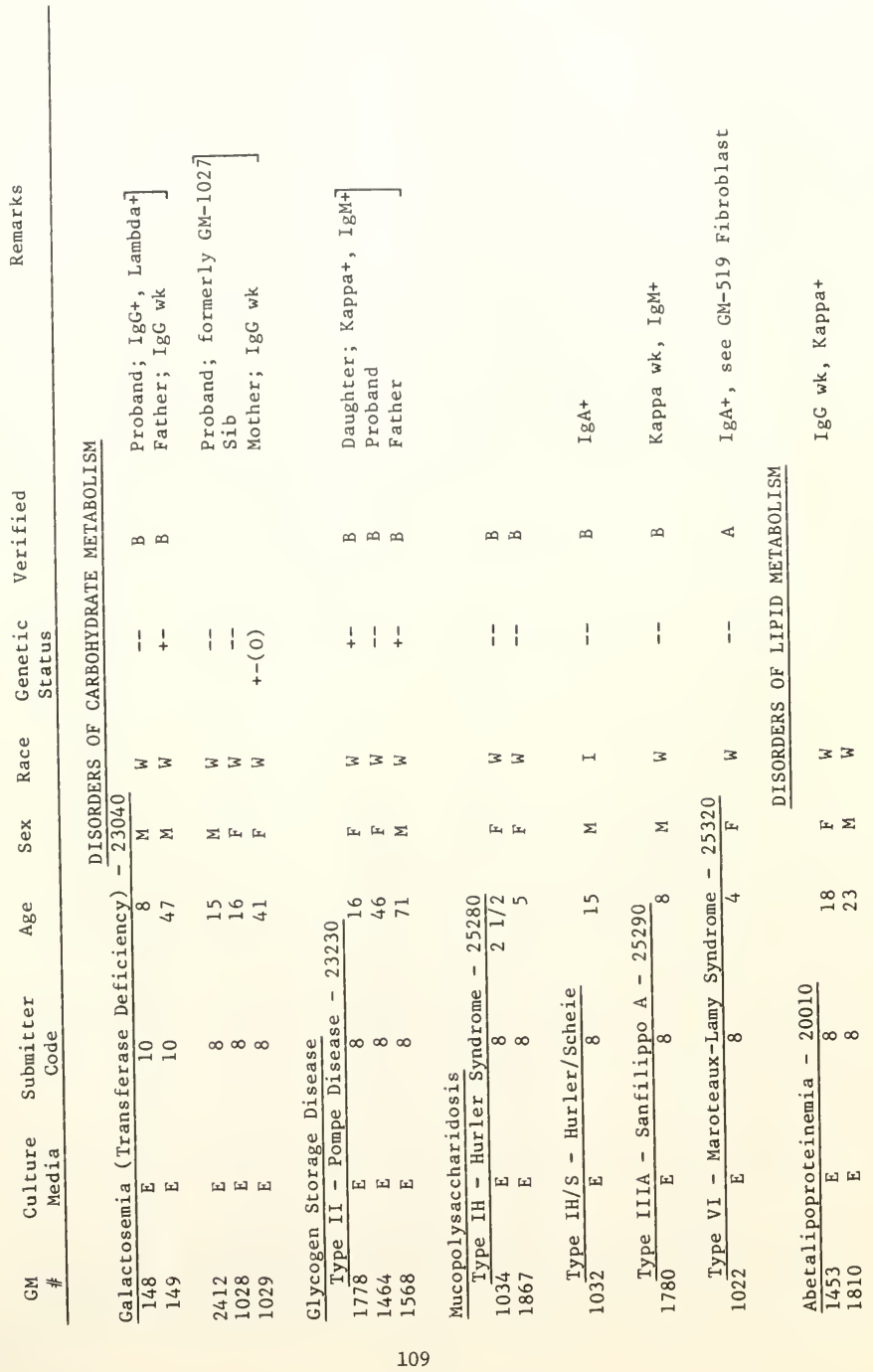




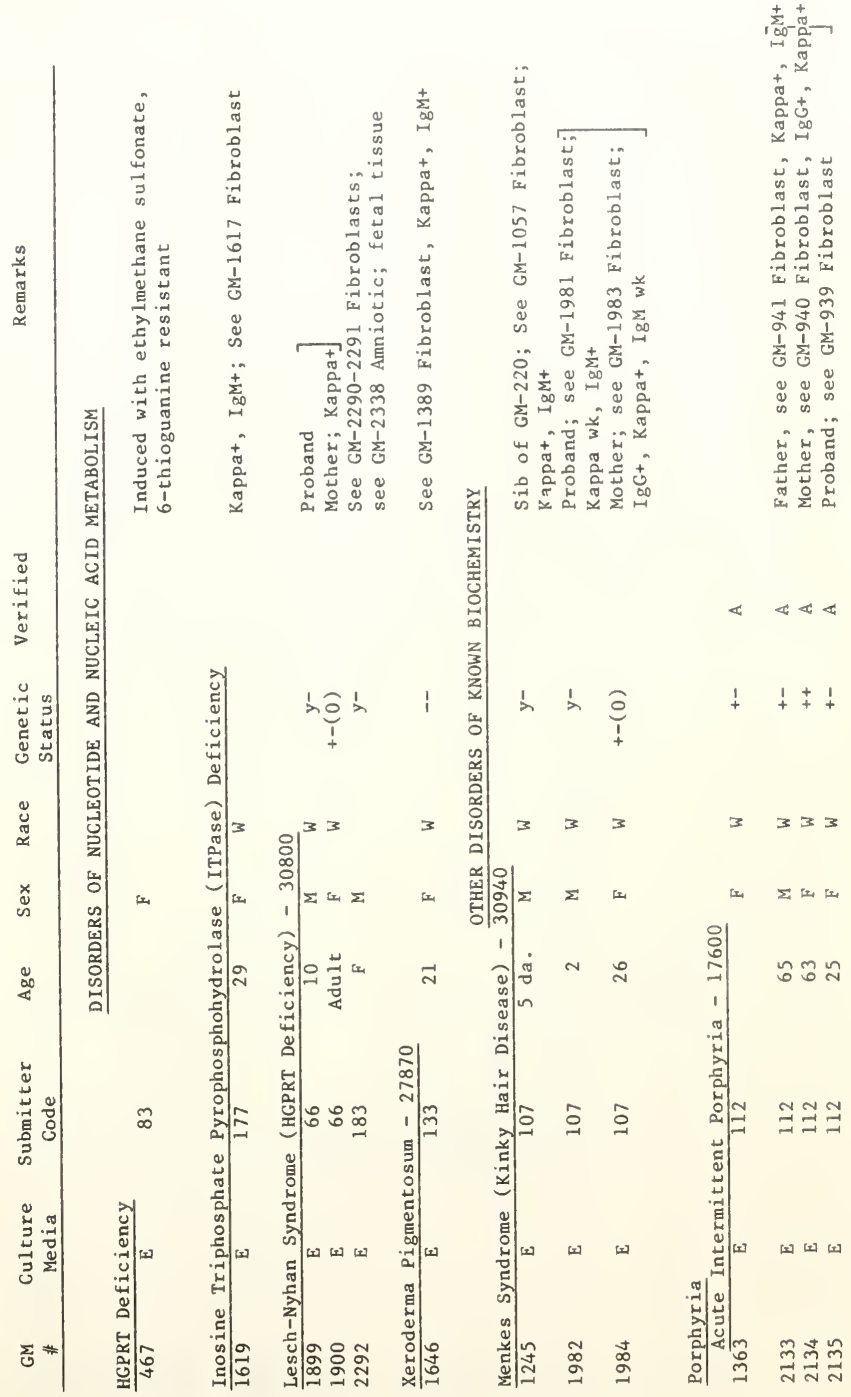




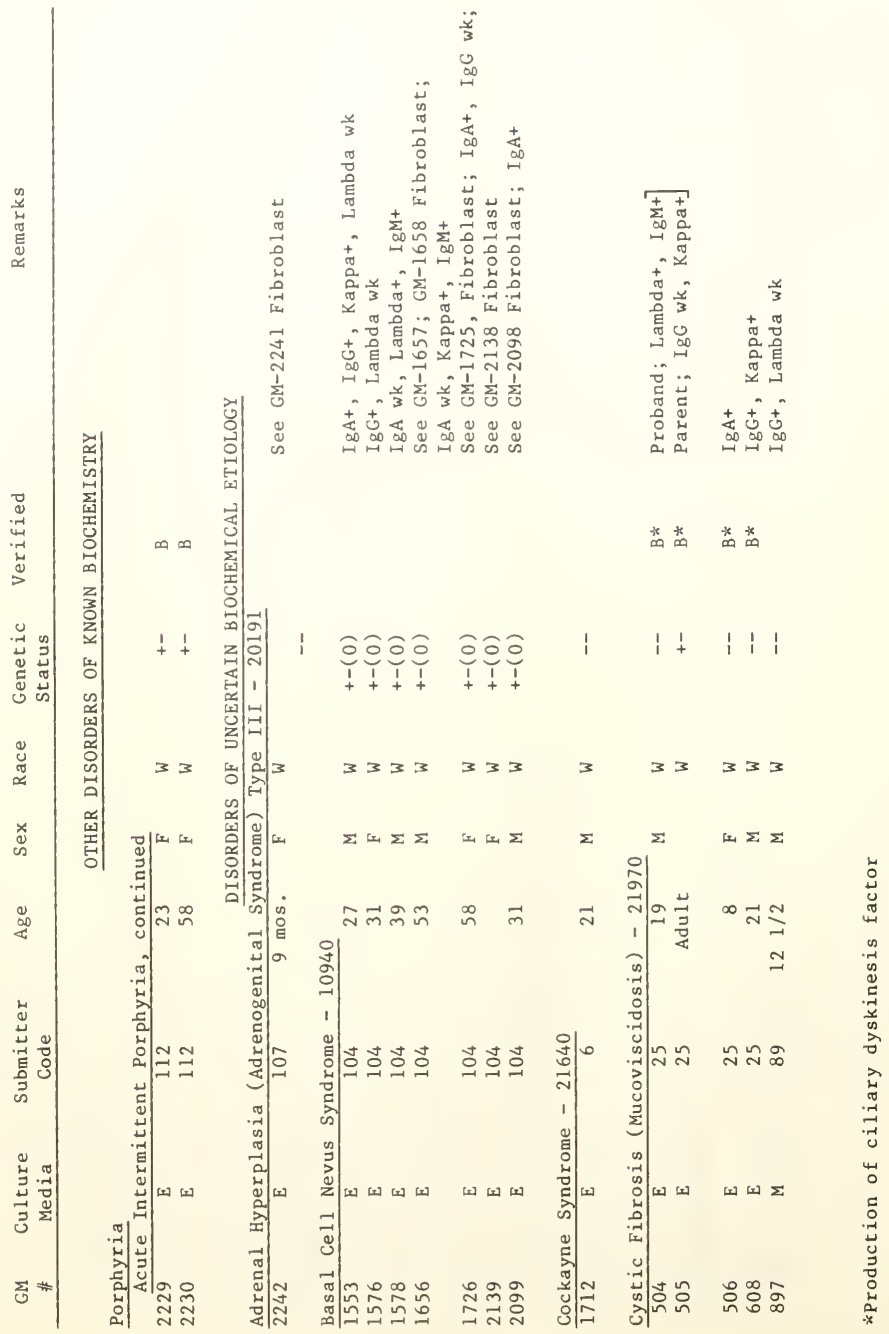




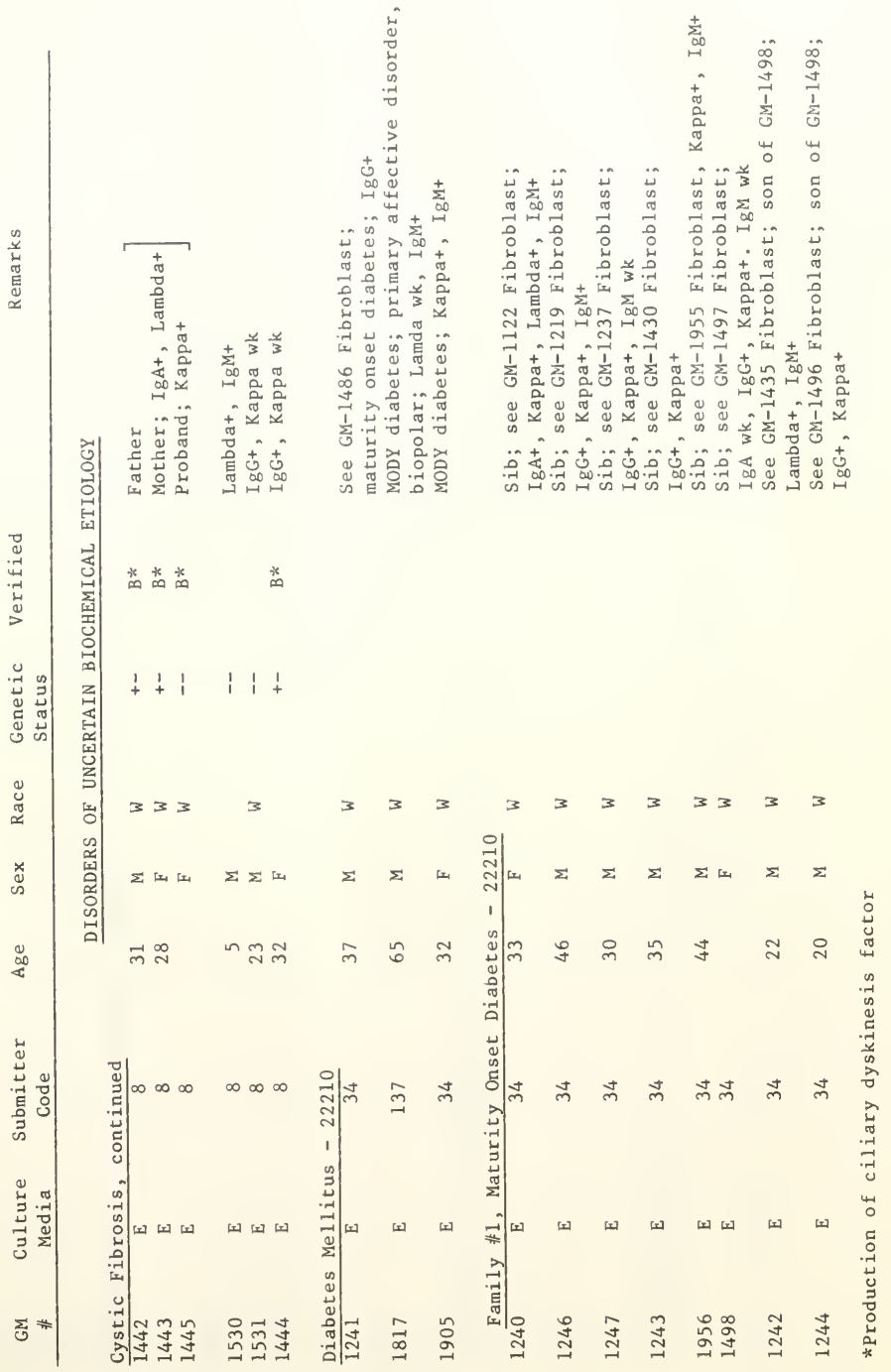




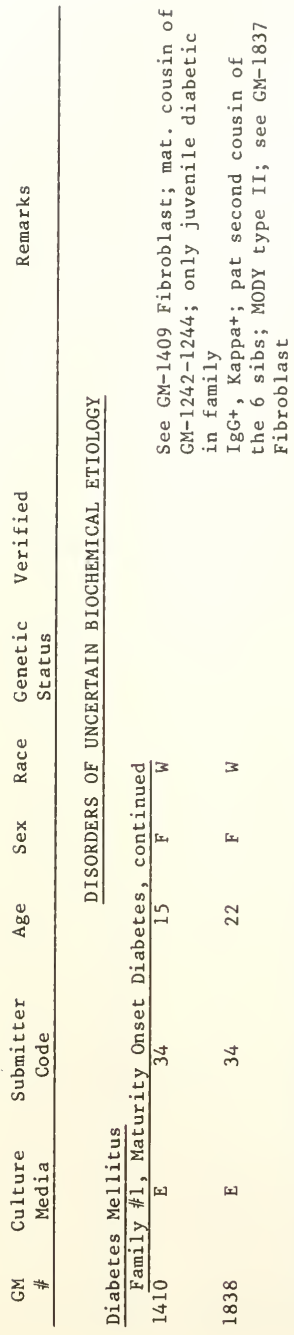

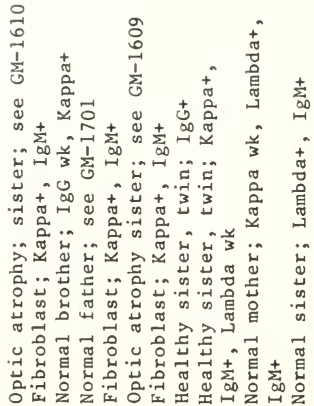

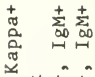

$+\frac{x+\infty}{3}+\frac{y}{3}$ $+\sum \frac{0}{4} \frac{0}{\square} \Sigma$ क
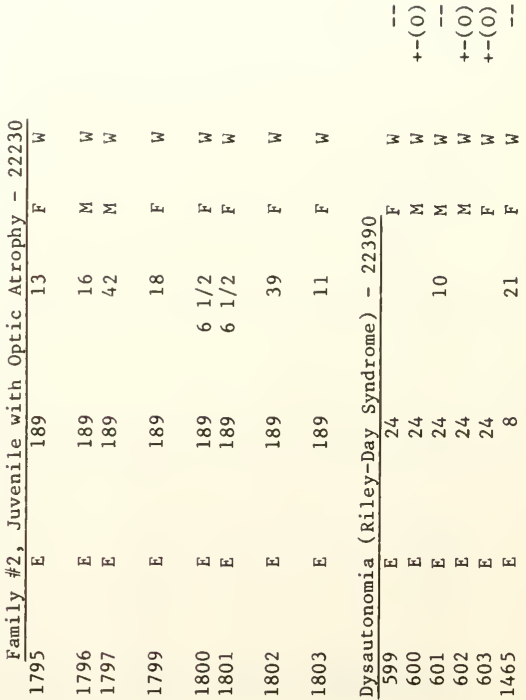


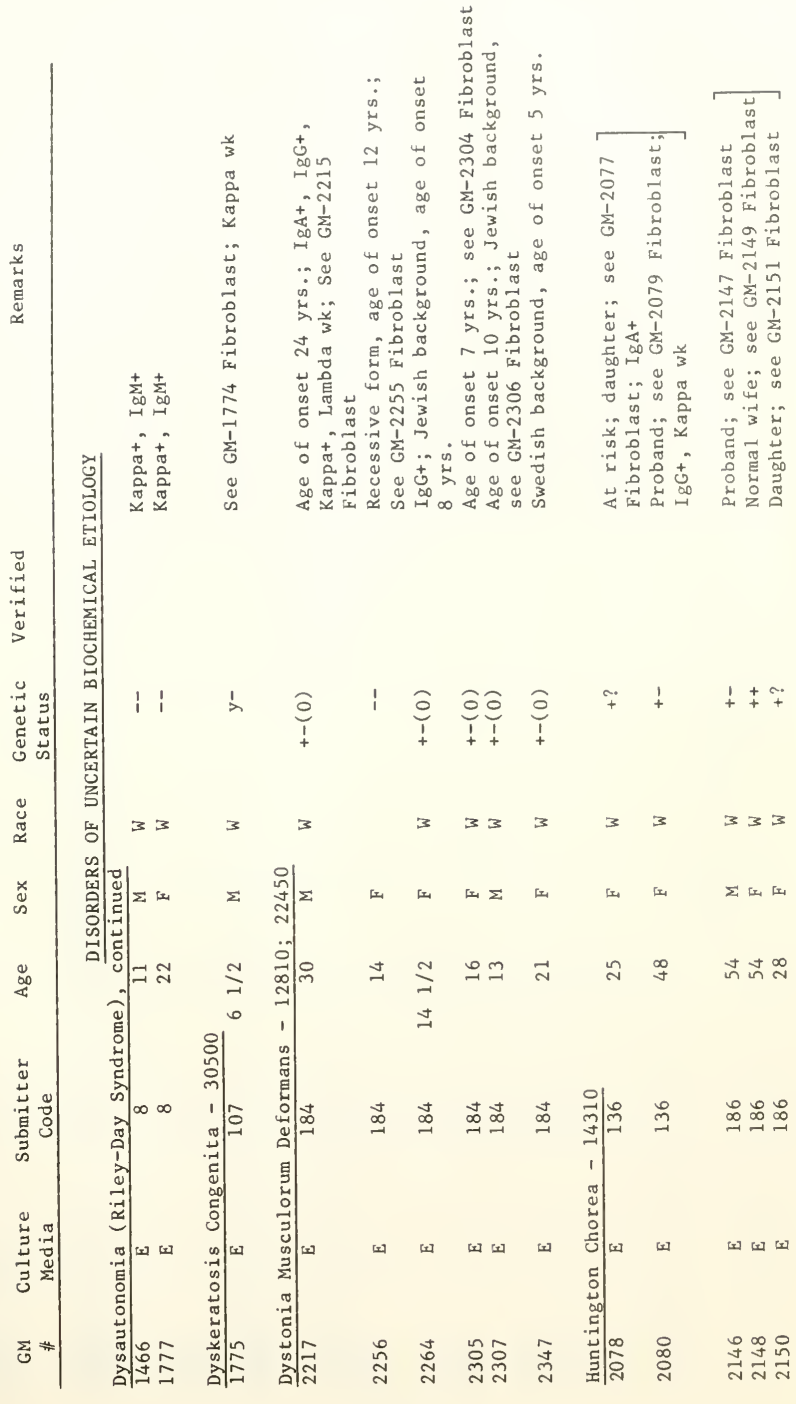




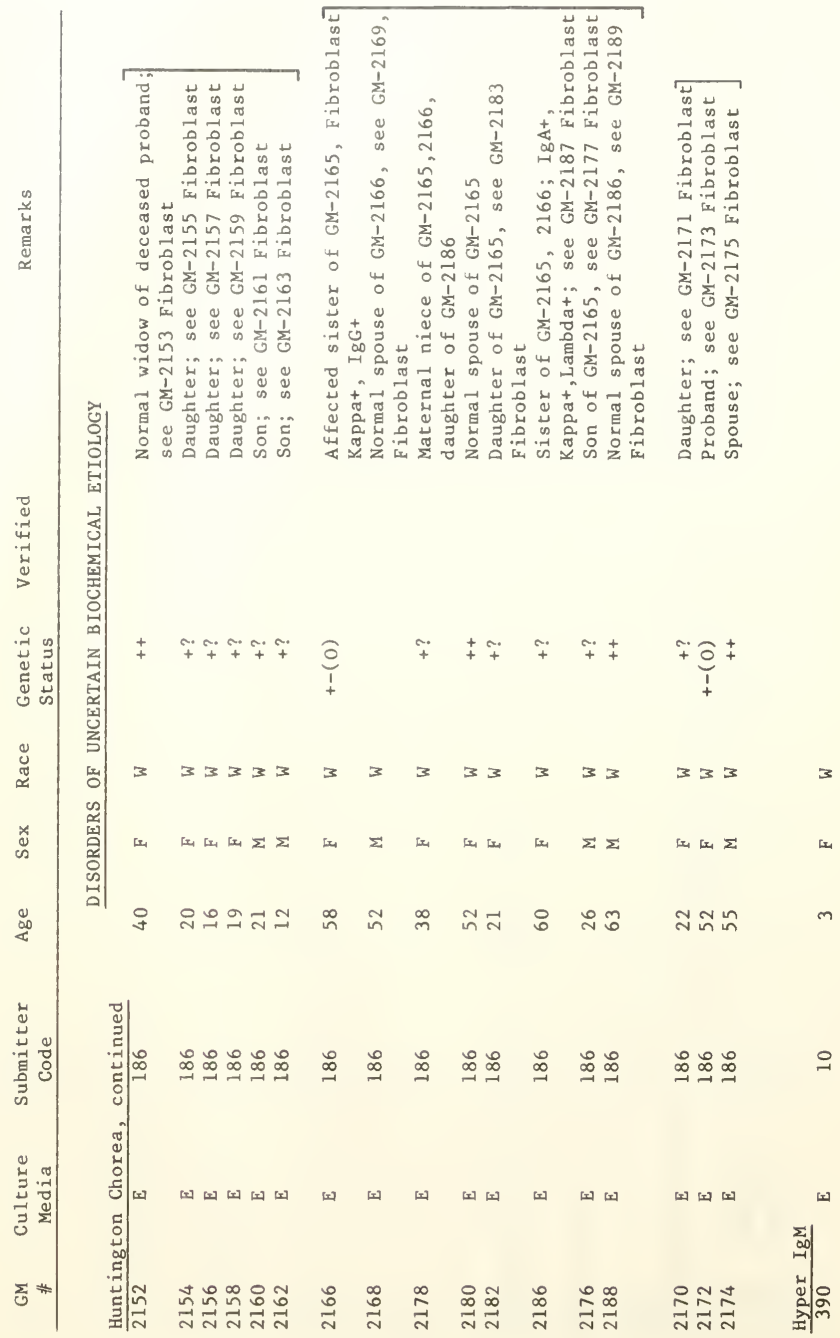




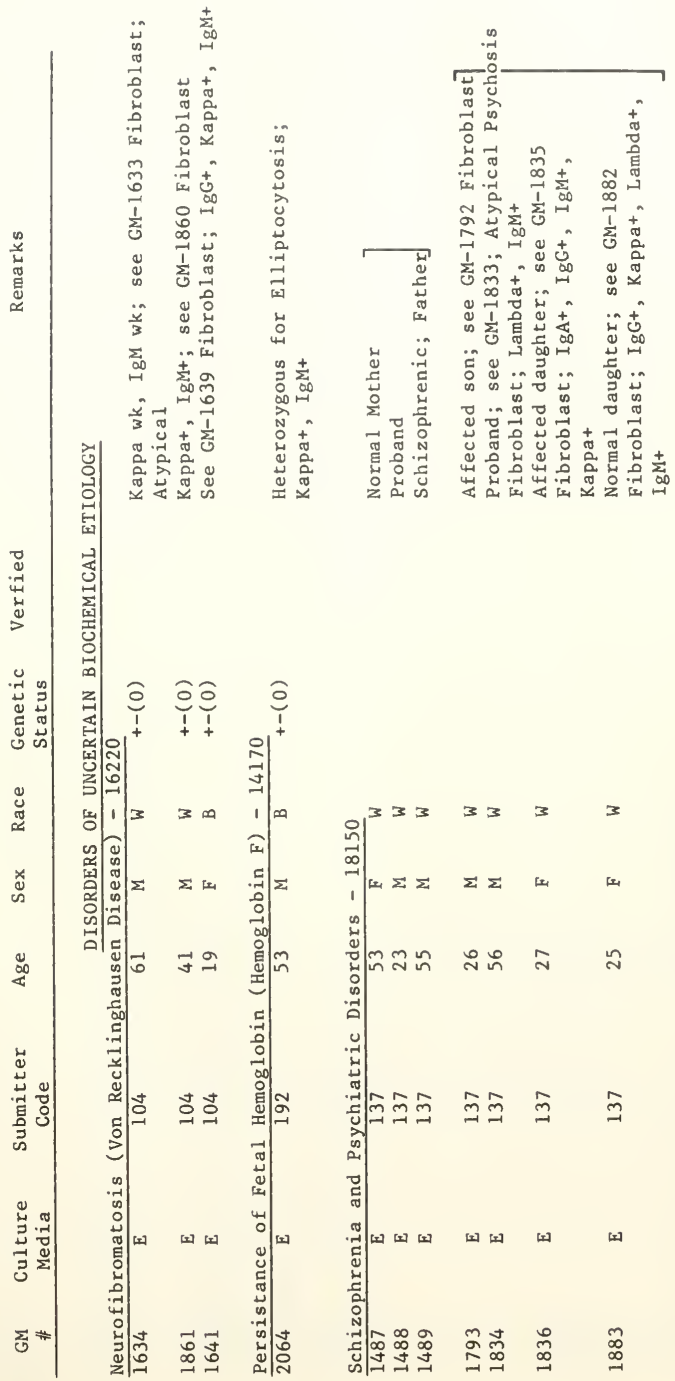




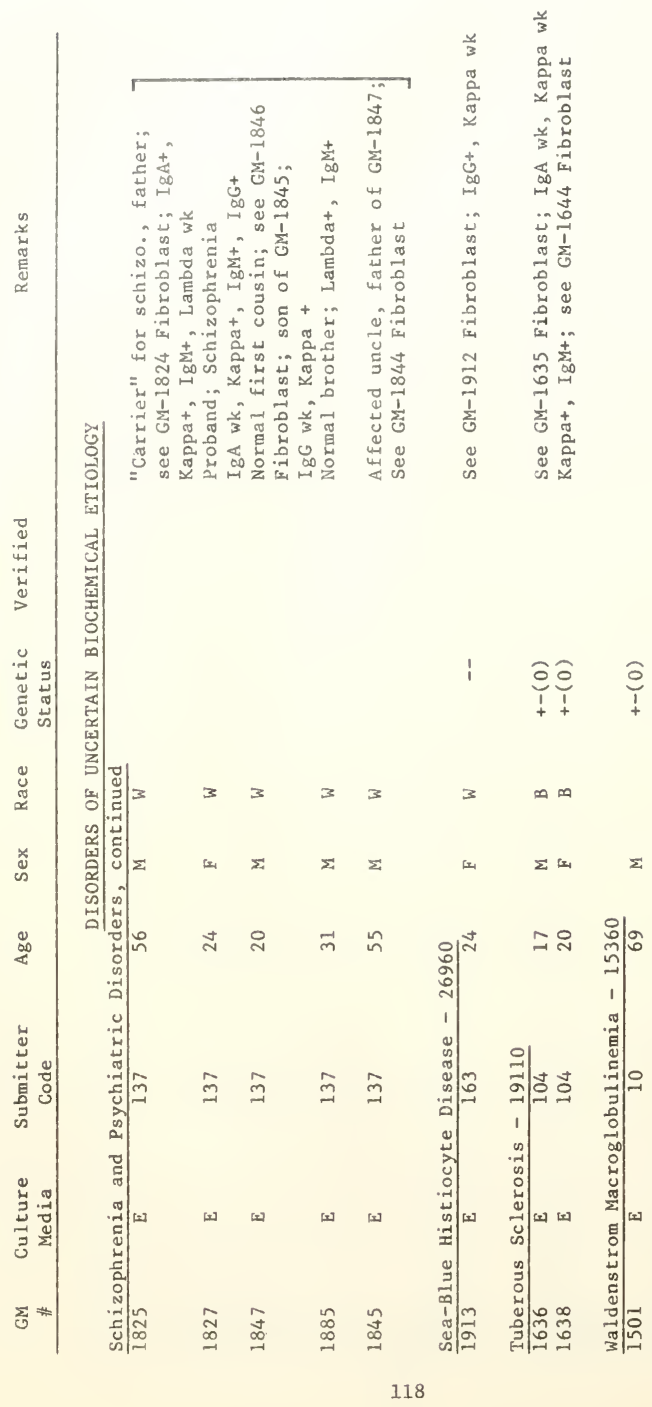




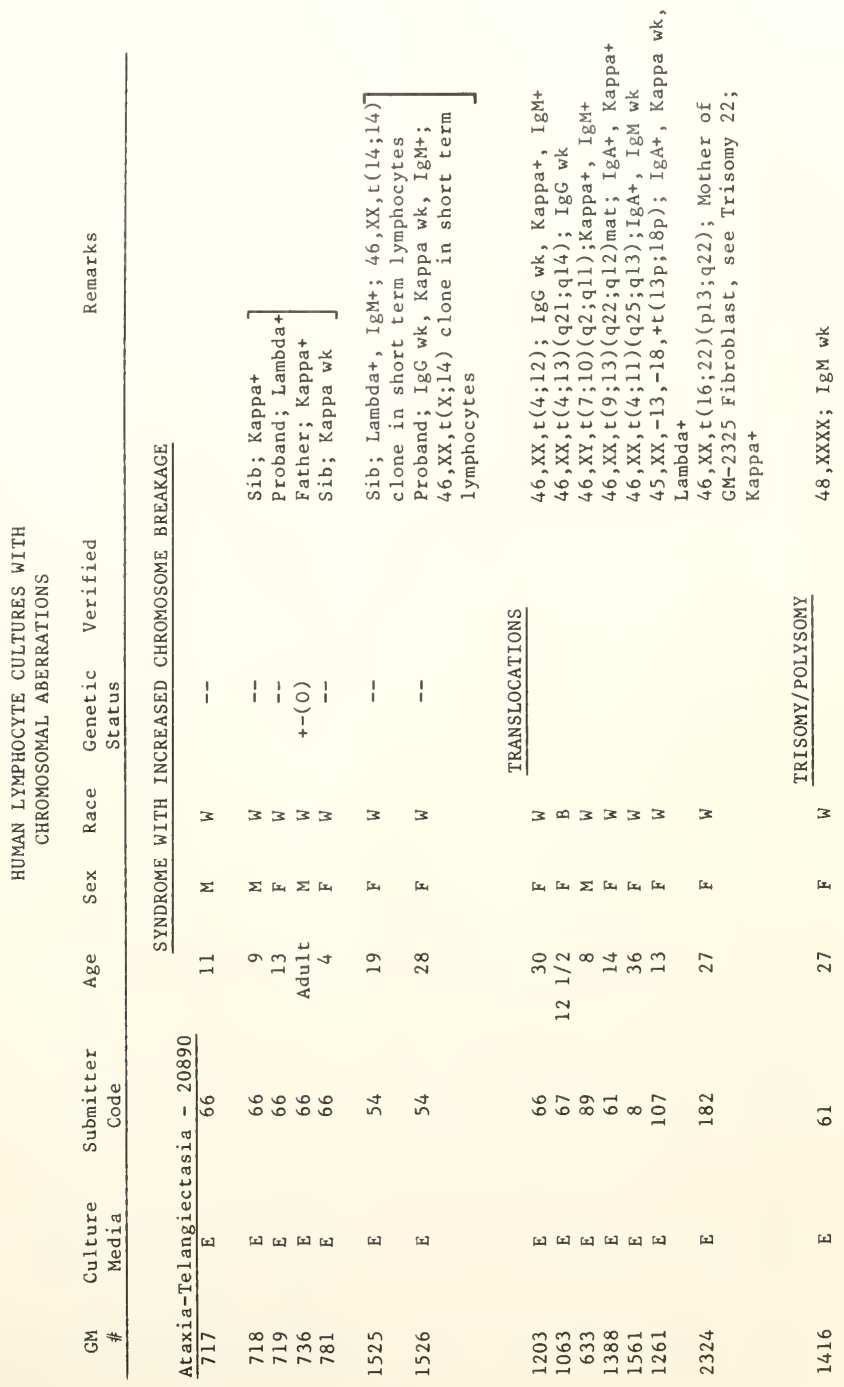




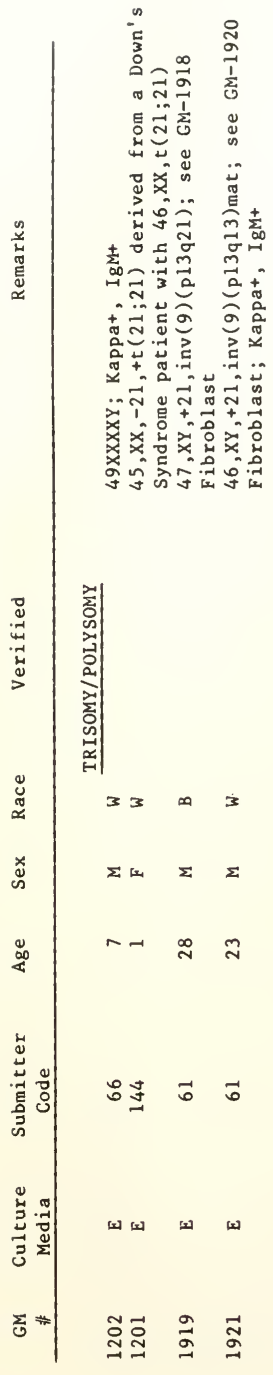




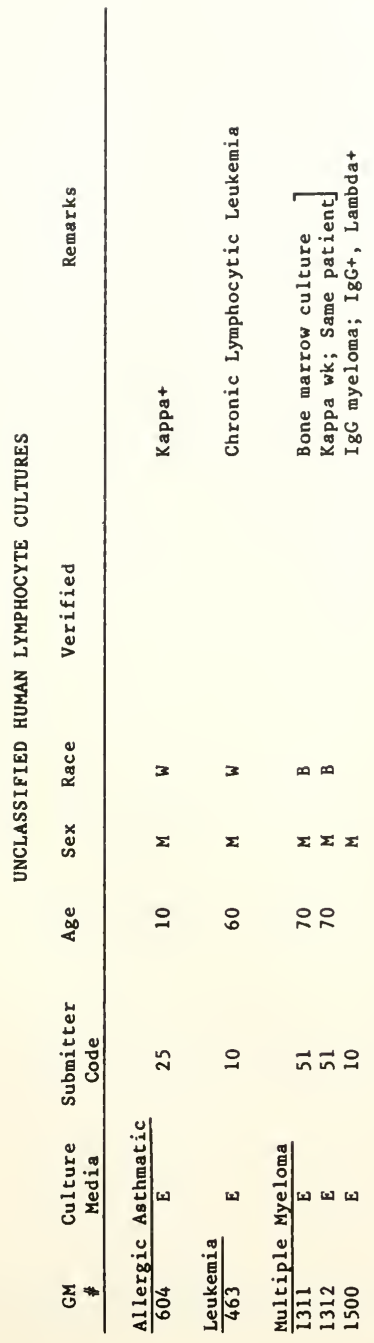




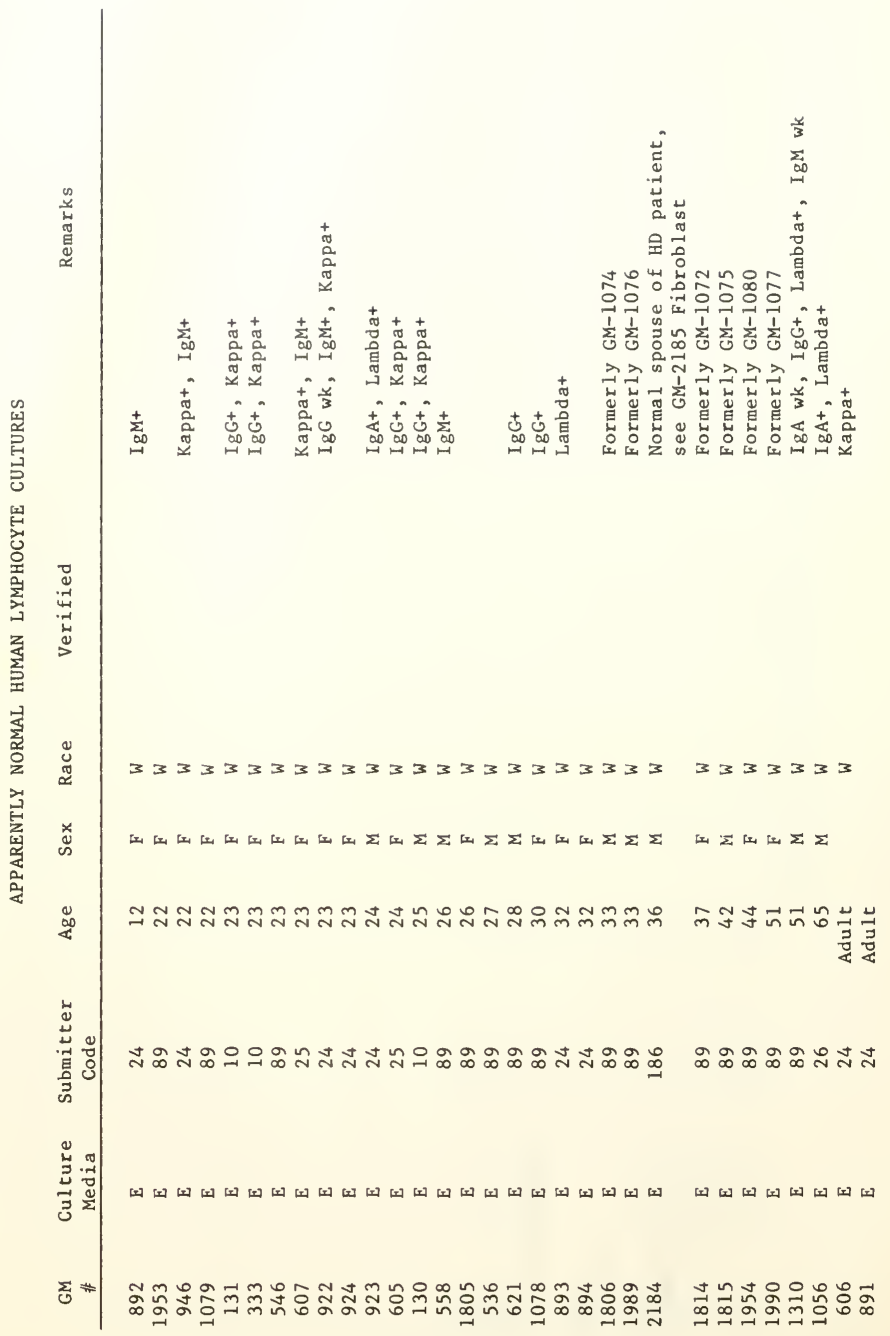




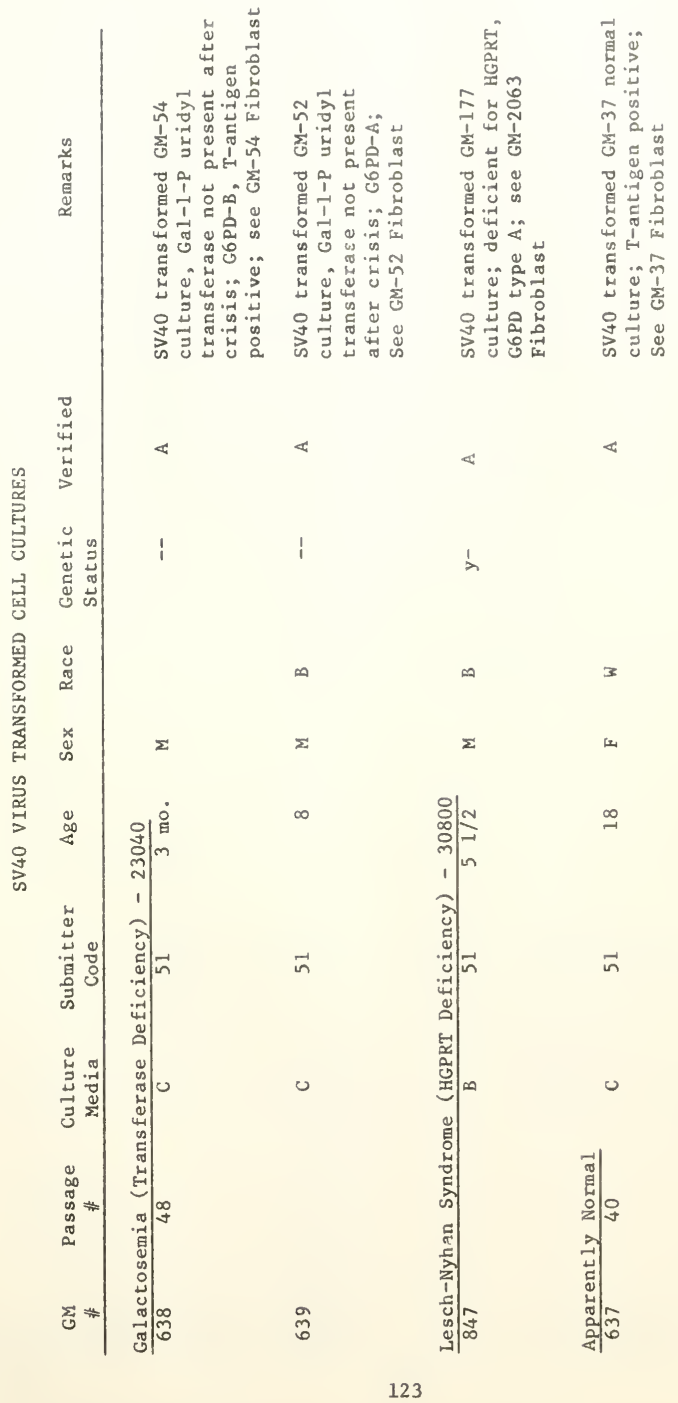




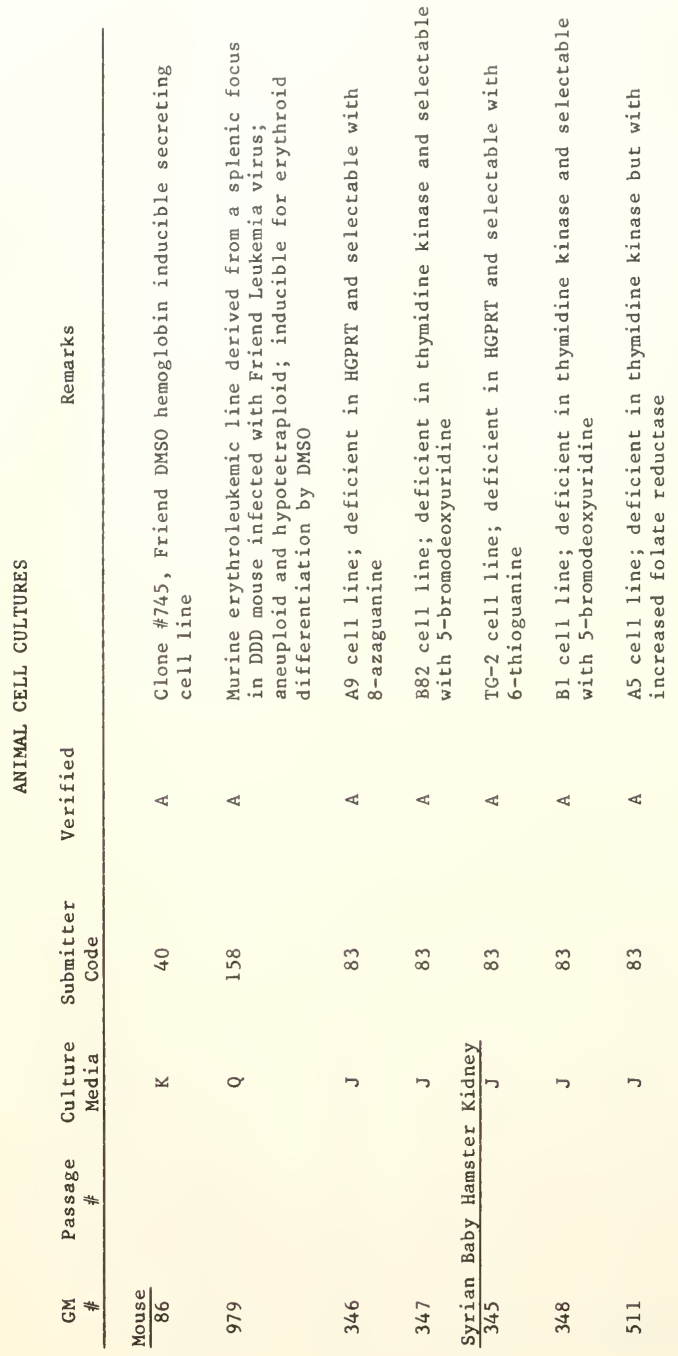




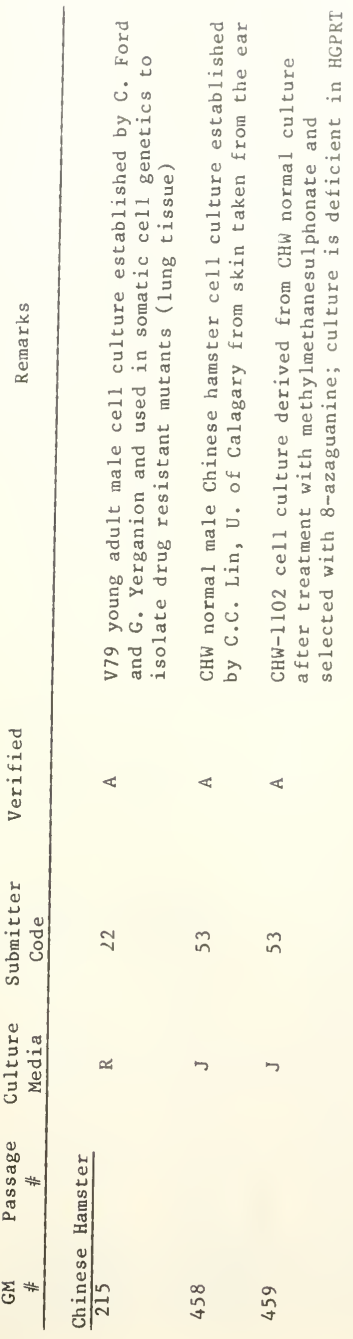




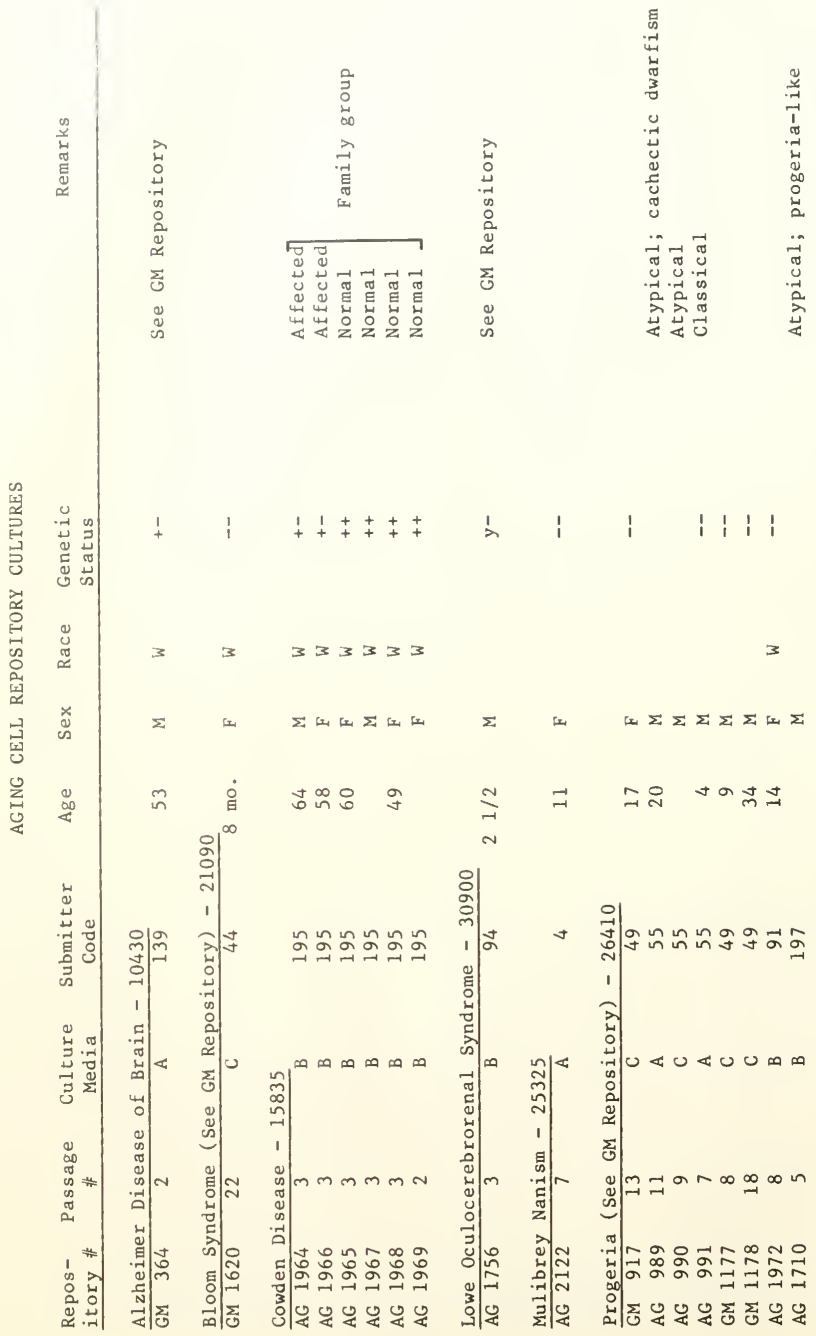




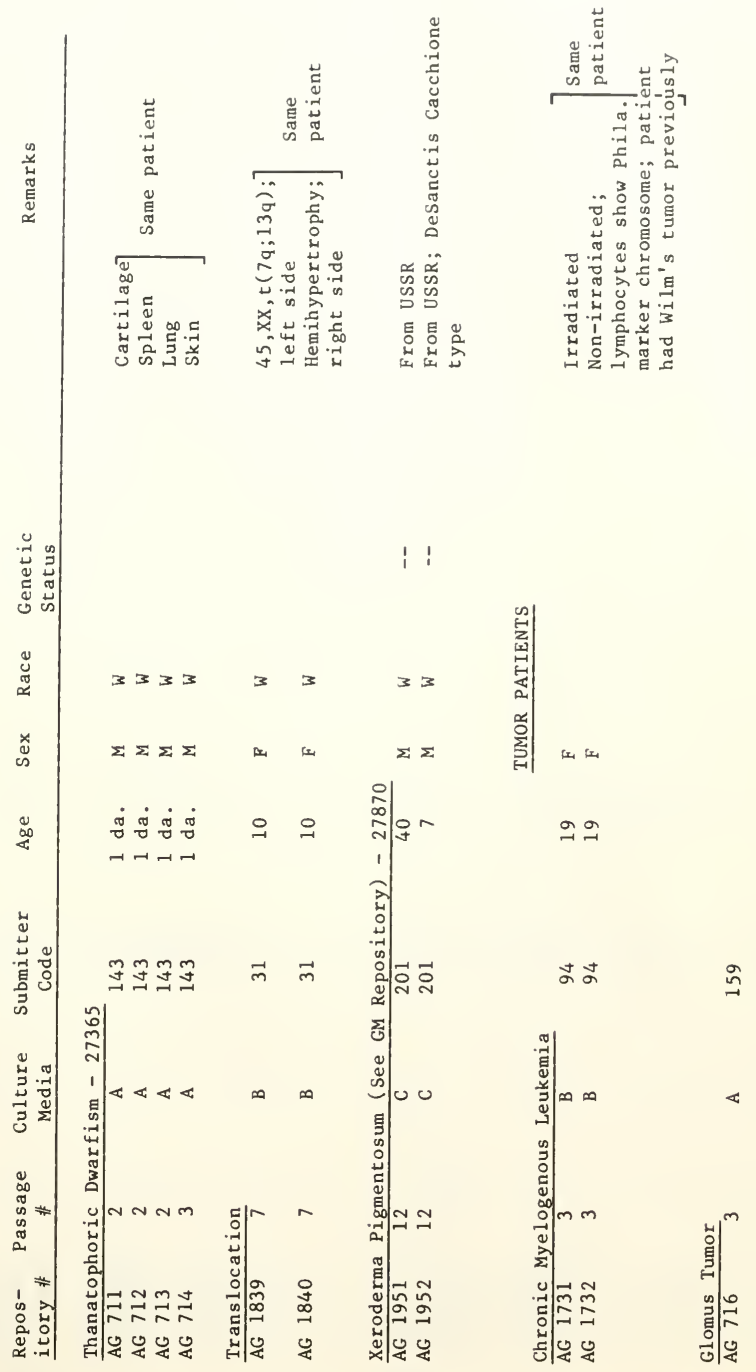



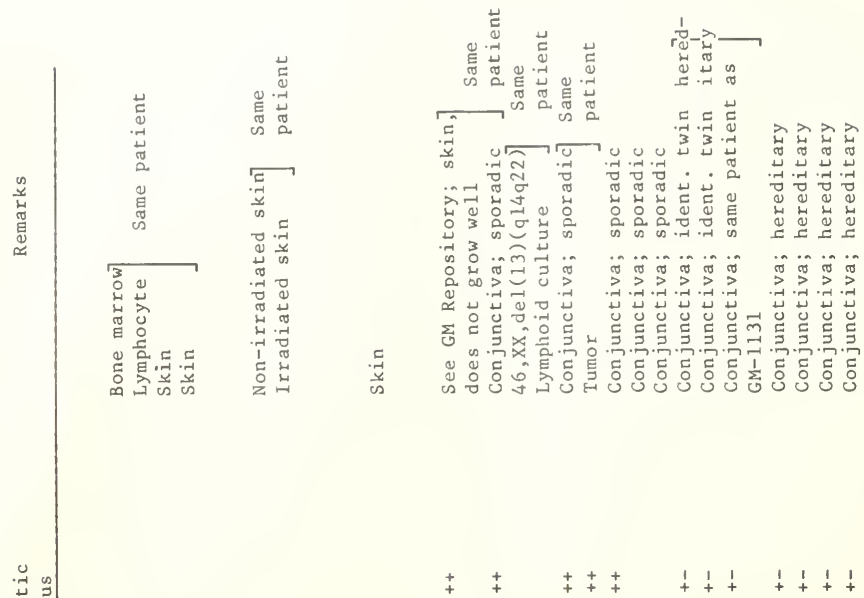

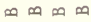

$3 \quad 33333$

ח $\infty \pi 3$

is is

$\Sigma$

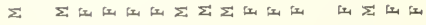

ผ

$\Sigma \Sigma \Sigma \Sigma$

14.

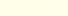

$\infty_{4}^{\infty} \quad$ in $\ln i n \operatorname{nin}$ ar

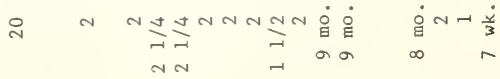

崩

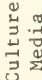

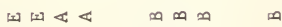

बे बे वे

๙ั

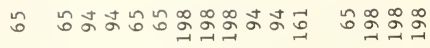

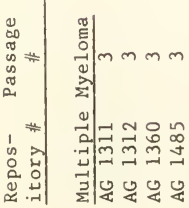

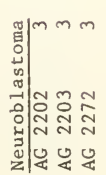
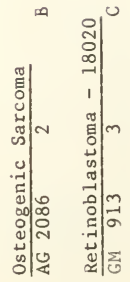

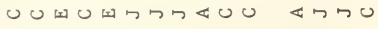

$m+m m m+\infty \omega m m$

$\lambda t \rightarrow t$

ป⿻一㇉丶

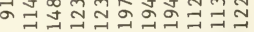

$\infty \infty \stackrel{\circ}{\infty} \infty$

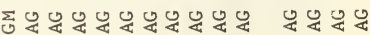




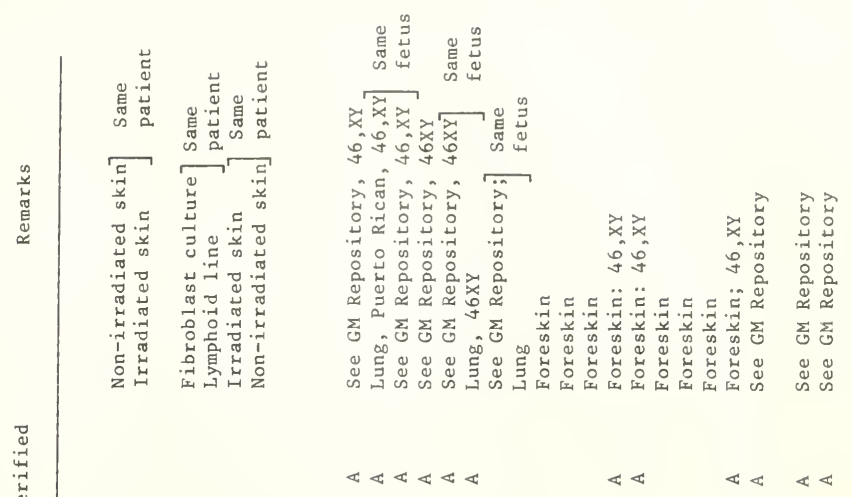

$\varangle<\ll<\ll$

$\stackrel{Ð}{\check{\varpi}}$

$3 \frac{3}{\infty} \sqcap \infty \infty \infty$

3333

$3 \oplus \infty$

3333

$\Sigma \Sigma \sum \Sigma \Sigma \Sigma \Sigma$

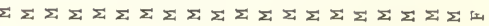

a 의어으든

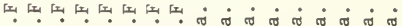

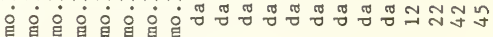
$\mathrm{Nm} m \mathrm{mmm} m \mathrm{~mm} m \mathrm{~mm}$

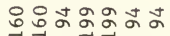




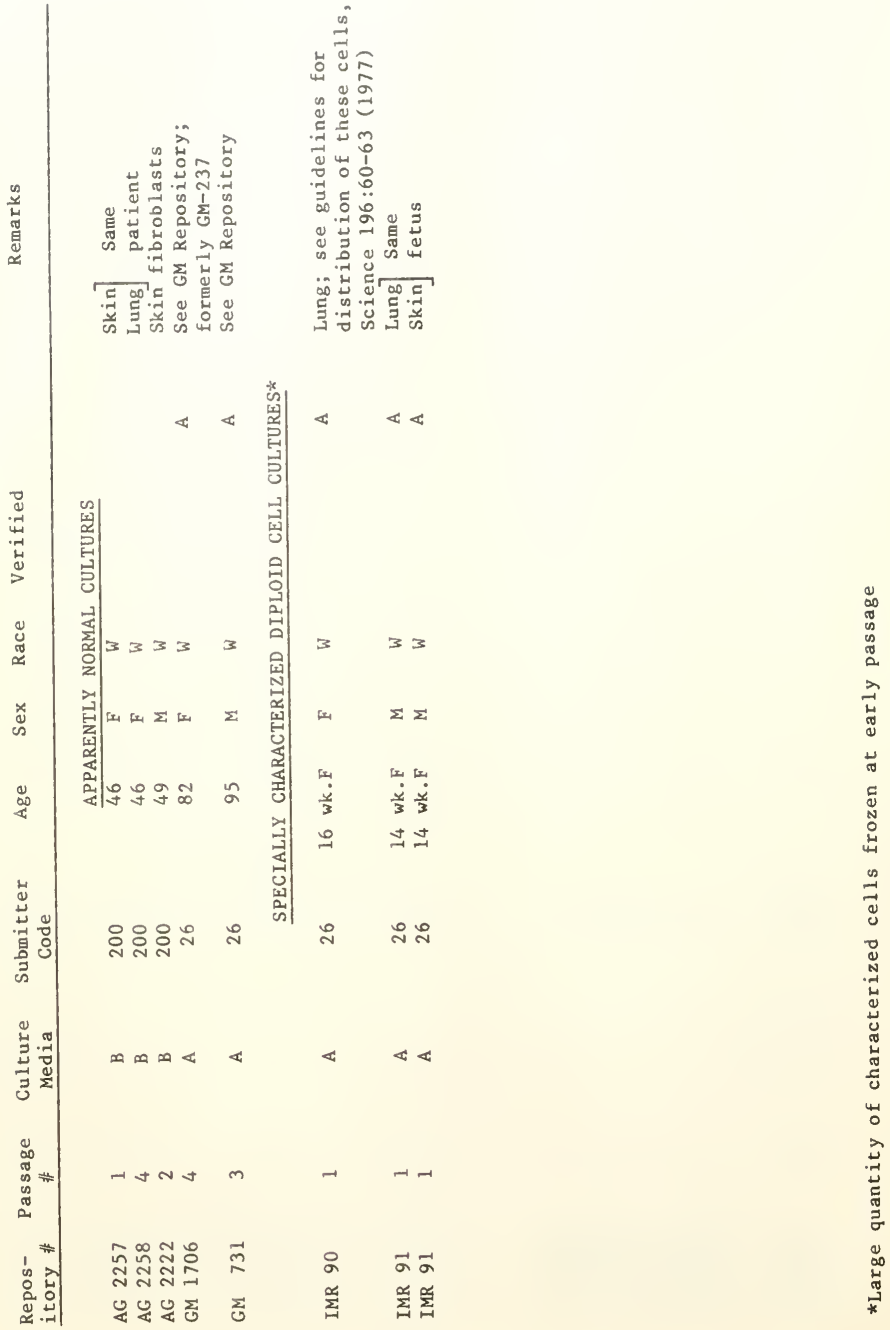




\section{CODE FOR CULTURE MEDIA}

For reference see: Morton, Helen C., A survey of Commercially Available Tissue Culture Media. In Vitro 6:89-108, 1970.

A - McCoy's 5A with 20\% fetal bovine serum (FBS) not inactivated (Iwakata and Grace modification)

B - Ham F12 with $20 \%$ FBS not inactivated

C - Minimum Essential Medium Eagle in Earle's BSS with $20 \%$ FBS not inactivated (with $2 \mathrm{x}$ concentration of essential and non-essential amino acids and vitamins)

D - Roswel1 Park Memorial Institute 1640 with $10 \%$ FBS inactivated $60^{\circ} \mathrm{C}$ for $1 / 2$ hour

E - Roswel1 Park Memorial Institute 1640 with $20 \%$ FBS inactivated $60^{\circ} \mathrm{C}$ for $1 / 2$ hour

F - Minimum Essential Medium Eagle in Earle's BSS with $30 \%$ FBS not inactivated (with $2 \mathrm{x}$ concentration of essential and nonessential amino acids and vitamins)

G - Ham F12 with $10 \%$ FBS not inactivated

$\mathrm{H}$ - McCoy's 5A with 10\% FBS not inactivated (Iwakata and Grace modification)

I - Roswel1 Park Memorial Institute 1640 with $20 \%$ FBS not inactivated

$\mathrm{J}$ - Minimum Essential Miedium Eagle in Earle's BSS with $10 \%$ FBS not inactivated (with $2 x$ concentration of esssential and non-essential amino acids and vitamins) 
K - Minimum Essential Medium Eagle in Earle's BSS with 15\% FBS not inactivated (with $2 x$ concentration of essential and non-essential amino acids and vitamins)

L - Minimum Essential Medium Eagle in Earle's BSS with $12 \%$ FBS not inactivated (with $2 \mathrm{x}$ concentration of essential and non-essential amino acids and vitamins)

M - Roswell Park Memorial Institute 1640 with 30\% FBS inactivated $60^{\circ} \mathrm{C}$ for $1 / 2$ hour

N - Minimum Essential Medium Eagle in Earle's BSS with $10 \%$ FBS inactivated $60^{\circ} \mathrm{C}$ for $1 / 2$ hour (with $2 \mathrm{x}$ concentration of essential and nonessential amino acids and vitamins)

0 - Roswe11 Park Memorial Institute 1640 with $30 \%$ FBS not inactivated

$\mathrm{P}$ - Ham F12 with $10 \%$ FBS inactivated $60^{\circ} \mathrm{C}$ for $1 / 2$ hour

Q - Ham F12 with $20 \%$ FBS inactivated $60^{\circ} \mathrm{C}$ for $1 / 2$ hour

R - Minimum Essential Medium Eagle in Earle's BSS with 5\% FBS not inactivated (with $2 x$ concentration of essential and nonessential amino acids and vitamins)

S - Minimum Essential Medium in Hanks' BSS with $10 \%$ FBS not inactivated (with $2 x$ concentration of essential and nonessential amino acids and vitamins)

T - Minimum Essential Medium in Hanks' BSS with 20\% FBS not inactivated (with $2 \mathrm{x}$ concentration of essential and nonessential amino acids and vitamins)

U - Ham F12 with $30 \%$ FBS not inactivated 


\section{SUBMITTER CODE}

The Human Genetic Mutant Cell Repository is indebted to the following investigators who graciously submitted biopsies, cultures, and data for characterization.

1. E. Akstein

2. $0 . A 1 \mathrm{fi}$

4. P. Aula

5. S. Barranco

6. A. Beaudet

7. P. Benke

8. N. Beratis
- Cytogenetics Lab., The Sheba Med. Cntr., Tel-Hashomer, Israel

- Div. of Med. Genetics, Children's Hosp. of Los Angeles, 4650 Sunset Blvd., Los Angeles, Calif. 90054

- Dept. of Med., Memorial Univ., St. John's, Newfoundland, Canada

- Dept. of Pathology, Univ. of Helsinki, 00290 Helsinki, Finland

- Div. of Cell Biology, Dept. of Human Biological Chemistry and Genetics, Univ. of Texas Med. Sch., Galveston, Texas 77550

- Dept. of Ped., Rm. 325E, Baylor Col1. of Med., 1200 Moursound Ave., Houston, Texas 77025

- Mailman Cntr. for Child Developement, Univ. of Miami Sch. of Med., P.0. Box 520006, Miami, Fla. 33152

- Head of Med. Genetics, Institute for Basic Research in Mental Retardation, 1050 Forest Hil1 Rd., Staten Island, N.Y. 10314 
9. E. Beut ler

10. A. Bloom

11. D. Bootsma

12. D. Borgaonkar

13. A. Boue

14. P. Bowen

15. W. Breg

16. J. Brown

17. P. Buchanan

18. W. Bucknall
- Dept. of Med., City of Hope Med. Cntr., 1500 East Duarte Rd., Duarte, Calif. 91010

- Dept. of Ped., 1507 Black Bldg., Coll. of Physicians and Surgeons of Columbia Univ., 630 W. 168th St., New York, N.Y. 10032

- Dept. of Cell Biology and Genetics, Erasmus Universitat Rotterdam, Postbus 1738 , Rotterdam, The Netherlands

- Div. of Med. Genetics, Dept. of Med., The Johns Hopkins Univ. Sch. of Med., Baltimore, Md. 21205

- Centre d'Etudes de Biologie Prenatale, Chateau de Longchamp - Carrefour de Longchamp Bois de Boulogne - 75016 Paris, France

- Dept. of Ped., 4-120 Clinical Sciences Bldg., Faculty of Med., Univ. of Alberta, Edmonton, Alberta, Canada T6G 2E1

- Southbury Training School, Southbury, Conn. 06488

- Dept. of Human Genetics, Medical College of Virginia, Richmond, Va.

- Director of Cytogenetics, Dept. of Ped., Sch. of Med., Univ. of North Carolina at Chapel Hil1, Chapel Hill, N.C. 27514

- Med. Genetics Sect., Dept. of Med., Baylor Co11. of Med., Houston, Texas 77025 
19. N. Buist

20. M. Bu 11

21 . H. Chen

22. E. Chu

23. J. Cleaver

24. E. Conod

25. J. Conover

26. L. Coriell

27. R. Cox

28. C. Croce

29. J. Davignon
- Dept. of Ped., Univ. of Oregon Health

Science Cntr., 3181 Sam Jackson Park Rd.,

Portland, Ore. 97201

- Dept. of Ped., New England Med. Cntr.

Boston, Mass. 02111

- Children's Hosp. of Michigan, 3901 Beaubien

Blvd., Detroit, Mich. 48201

- Dept. of Human Genetics, Univ, of Michigan Med. Sch., 1137 E. Catherine St., Ann Arbor, Mich. 48104

- Laboratory of Radiobiology, Univ. of Calif. Med. Sch. at San Francisco, San Francisco, Calif. 94143

- Dept. of Ped., Pulmonary Div., Albert Einstein Col1. of Med., 1300 Morris Park Ave., Bronx, N.Y. 10461

- Dept. of Ped., Pulmonary Div., Albert Einstein Col1. of Med., 1300 Morris Park Ave., Bronx, N.Y. 10461

- Institute for Medical Research, Copewood St., Camden, N.J. 08103

- New York Univ. Med. Cntr., Sch. of Med., 550 First Ave., New York, N.Y. 10016

- Wistar Institute, 36th and Spruce Sts., Philadelphia, Pa. 19104

- Clinical Research Inst. 110 Pine Ave. West, Montreal, H2W 1R7, Canada 
30. A. de la Chapelle - Dept. of Med. Genetics, Univ. of Helsinki, Haartmaninkatu 3, 00290 Helsinki 29, Finland

31. R. DeMars

32. R. Desnick

33. L. E1sas

34. S. Fajans

35. I. Fand

37. P. Fialkow

38. L. Fleisher

39. U. Franke
- Dept. of Genetics, Univ. of Wisconsin, Madison, Wis. 53706

- Dept. of Ped., Div. of Med. Genetics, Mt. Sinai Med. Sch., Fifth Ave. and 100th St., New York, N.Y. 10029

- Div. of Med. Genetics, Dept. of Ped., Emory Univ. Sch. of Med., Atlanta, Ga. 30322

- Div. of Endocrinology and Metabolism, Metabolism Research Unit, Univ. of Michigan Med. Cntr., Ann Arbor, Mich. 48104

- Creedmoor Inst. for Psychobiologic Studies, Station 60, Queens Village, N.Y. 11427

36. M. Ferguson-Smith - Genetic Advisory Cntr., Royal Hosp. for Sick Children, Yorkhi11, Glasgow G38SJ, Scotland

- Div. of Med. Genetics, Univ. of Washington Sch. of Med., Seattle, Wash. 98195

- Dept. of Human Develop. and Genetics, Inst. for Basic Res. in Mental Retard., 1050 Forest Hill Rd., Staten Island, N.Y. 10314

- Dept. of Ped., M-009, Sch. of Med., Univ. of California at San Diego, La Jolla, Calif. 92093 
40. C. Friend

41. S. Gartler

42. G. Gaul1

43. P. Gerald

44. J. German

45. M. Gertner

46. F. Giannel1i

47. F. Gilbert

48. M. Golbus

49. H. Goldman

50. J. Goldstein
- Cntr. for Experimental Cell Biology, Mt.

Sinai Sch. of Med., The City Univ. of N.Y., Fifth Ave, and 100th St., New York, N.Y. 10029

- Dept. of Med. and Genetics, Sch. of Med., Univ. of Washington, Seattle, Wash. 98195

- Inst. for Basic Res. in Mental Retard., 1050 Forest Hill Rd., Staten Island, N.Y. 10314

- Children's Hosp. Med. Cntr., 300 Longwood Ave., Boston, Mass. 02115

- N. Y. Blood Cntr., 310 East 67th St., New York, N.Y. 10021

- Dept. of Ped., Mt. Sinai Sch. of Med., 5th Ave, and 100th St., New York, N.Y. 10029

- Paediatric Res. Unit., Guy's Hosp. Med. Sch., Cameron House, London, SEI 9RT, England

- Dept. of Human Genet., Med. School, Univ. of Pa., Philadelphia, Pa. 19174

- Dept. of Obstetrics and Gynecology, Univ. of Calif. Sch. of Med., San Francisco, Calif. 94143

- McGill Univ., Montreal Children's Hosp. Res. Inst., 2300 Tupper St., Montreal, 108 Quebec, Canada

- Div. of Med. Genetics, Dept. of Internal Med., Southwest Texas Med. Sch., 5323 Harry Hines Blvd., Dallas, Texas 75235 
51. A. Greene

52. N. Hahnemann

53. J. Hamerton

54. D. Harnden

55. R. Hay

56. F. Hecht

57. J. Herd

59. M. Hodes

58. K. Hirschhorn

M. Hodes

60. D. Holsclaw
- Institute for Medical Research, Copewood St., Camden, N.J. 08103

- Univ. Institute of Med. Genetics, 14, Tagensivej-Copenhagen N., Denmark

- Dept. of Genetics, Children's Cntr., 685 Bannatyne Ave., Winnipeg, Manitoba R3E OW1 Canada

- Dept. of Cancer Studies, Med. Sch., Univ. of Birmingham, Birmingham B15 2TJ, Great Britain

- American Type Culture Collection, Cell Culture Dept., 12301 Parklawn Dr., Rockville, Md. 20852

- Child Develop. and Rehabilitation Cntr., Univ. of Oregon Health Sciences Cntr., P.0. Box 574, Portland, Ore. 97207

- Dept. of Ped., Creighton Univ. Sch. of Med., 10th and Castelar Sts., Omaha, Neb. 68108

- Dept. of Ped., Annenberg Bldg., Mt. Sinai Sch. of Med., 5th Ave. and 100th St., New York, N.Y. 10029

- Dept. of Med. Genetics, Indiana Univ. Sch. of Med., 1100 W. Michigan St., Indianapolis, Ind. 46202

- Dept. of Ped., Hahnemann Med. Co11., $230 \mathrm{~N}$. Broad St., Philadelphia, Pa. 19102 
61. P. Howard-Peebles - Inst. for Genetics, Univ. of Southern Mississippi, Southern Station Box 5153, Hattiesburg, Miss. 39401

62. R. Howe 11

- Dept. of Ped., Univ. of Texas Med. Sch. at Houston, Rm. 208, John Freeman Bldg., P.O. Box 20708, Texas Med. Cntr., Houston, Texas 77025

63. Y. Hsia

- Dept. of Human Genet., Sch. of Med., Yale Univ., 333 Cedar St., New Haven, Conn. 06510

64. L. Hsu

- Dept. of Ped., Mt. Sinai Sch. of Med., Fifth Ave. and 100th St., New York, N.Y. 10029

65. P. Huang

- Dept. of Biochemistry, Johns Hopkins Sch. of Hygiene and Public Health, 615 N. Wolfe St., Baltimore, Md. 21205

66. L. Jackson

- Div. of Med. Genetics, Jefferson Med. Col1., 1025 Walnut St., Philadelphia, Pa. 19107

67. E. Jenkins

- Dept. of Cytogenetics, Inst. for Basic Res. in Mental Retard., 1050 Forest Hil1 Rd., Staten Island, N.Y. 10314

68. M. Kaback

- Div. of Med. Genetics, Harbor General Hosp. UCLA Sch. of Med., Torrance, Calif. 90509

69. S. Kaffe

- Div. of Med. Genetics, Dept. of Pediatrics, Mt. Sinai Sch, of Med., Fifth Ave. at 100th St., New York, N.Y. 10029

70. T. Kelly

- Box 201, Dept. of Ped., Univ. of Virginia, Charlottesville, Va. 22901 
71. W. Kel1ey

- Div. of Rheumatic and Genetic Disorders, Duke Univ. Med. Sch., Durham, N.C. 27710

72. A. Khachadurian - Dept. of Med., 8th Floor, Rutgers Univ. Med. Sch., Piscataway, N.J. 08854

73. H. Kim

- Dept. of Ped., Beth Israel Med. Cntr., 421 East 14th St., New York, N.Y. 10009

74. M. Kistenmacher - Dept. of Cytogenetics, St. Christopher's Hosp. for Children, 2600 N. Lawrence Sts., Philadelphia, Pa. 19133

75. H. Klinger

- Dept. of Genetics, Albert Einstein Co11. of Med., 1300 Morris Park Ave., New York, N.Y. 10461

76. J. Knittle

77. G. Kohn

78. B. Kousseff

79. E. Krompotic

80. R. Krooth 164 th St., Jamaica, N.Y. 11432
- Dept. of Ped., Mt. Sinai Sch. of Med., 5th Ave. and 100th St., New York, N.Y. 10029

- Dept. of Genetics, Mayer de Rothschild Hadassah Univ. Hosp., Kiryat Hadassah Jerusalem, Israel

- Dept. of Ped., Queens Hospital Center,

- Dept. of Experimental Pathology, Mt. Sinai Hosp. Med. Cntr., Chicago, I11. 60608

- Dept. of Human Genetics and Develop., Coll. of Physicians and Surgeons, Columbia Univ., Black Bldg., Rm. 1511, 650 W. 168th St., New York, N.Y. 10032. 
81. T. Kushnick

82. C. Lin

83. J. Littlefield

84. G. Liu

85. J. Lockwood

86. R. Longhi

87. M. Macintyre

88. M. Mahoney

89. M. Manduka

90. J. Marks

91. G. Martin

92. I. Maumenee
- Dept. of Ped., New Jersey Coll. of Med., 100 Bergen St., Newark, N.J. 07103

- Div. of Ped. and Med. Biochemistry, Faculty of Med., Univ. of Calgary, Calgary Alberta T2N 1N4, Canada

- Dept. of Ped., Johns Hopkins Univ. Sch. of Med., Baltimore, Md. 21205

- Rockefeller Univ., Rm. 515, 66th St. and York Ave., Manhattan, N.Y. 10021

- P.0. Box 109, Dept. of Ped., Sch. of Med. Univ. of Calif, at San Diego, La Jolla, Calif. 92037

- Inst. for Basic Res, in Mental Retard., 1050 Forest Hill Rd., Staten Island, N.Y. 10314

- Dept. of Anatomy and Ped., Case Western Reserve Univ., Cleveland, Ohio 44106

- Dept. of Human Genetics, Yale Univ. Sch. of Med., 333 Cedar St., New Haven, Conn. 06510

- Institute for Medical Research, Copewood St., Camden, N.J. 08103

- Dept. of Ped., Univ. of Texas Health Science Cntr. at Dallas, 5323 Harry Hines Blvd., Dallas, Texas 75235

- Dept. of Pathology, Univ. of Washington Sch. of Med., Seattle, Wash. 98105

- The Wilmer Opthalmologic Inst., $601 \mathrm{~N}$. Broadway, Baltimore, Md. 21205 
93. D. McNamara

94. A. Meadows

95. W. Mellman

96. B. Migeon

97. R. Miller

98. S. Miwa

99. G. Morrow

100. T. Moshug

101. W. Nyhan

102. S. Orkin

103. R. Parkman

104. G. Peck
- Rockefeller Univ., 66th St. East at York Ave., New York, N.Y. 10021

- Children's Hosp. of Phila., 34th and Civic Cntr. Blvd., Philadelphia, Pa. 19104

- Dept. of Human Genetics, Univ. of Penn. Med. Sch., Richards Bldg. G/4, Philadelphia, Pa. 19174

- Dept. of Ped., Johns Hopkins Univ. Med. Sch., 601 N. Broadway, Baltimore, Md. 21205

- Institute for Medical Research, Copewood St., Camden, N.J. 08103

- Third Dept. of Internal Med., Yamaguchi Univ. of Med., UBE, Yamaguchi, 755 Japan

- Dept. of Ped., Univ. of Arizona Med. Sch., Tucson, Ariz. 85724

- Dept. of Ped., Hahnemann Med. Coll., 230 N. Broad St., Philadelphia, Pa. 19102

- Dept. of Ped., Sch. of Med., Univ. of Calif. at San Diego, P.0. Box 109, La Jolla, Calif. 92037

- Dept. of Med., Children's Hosp. Med. Cntr., 300 Longwood Ave., Boston, Mass. 02115

- Lab. of Immunology, Children's Hosp. Med. Cntr., 300 Longwood Ave., Boston, Mass. 02115

- Bldg. 10, Rm. 12N 238, Dermatology Branch, National Cancer Inst., Bethesda, Md. 20014 
105. M. Philippart - Neuro-Psychiatric Inst., Rm. 48-228-B, Cntr. for the Health Sciences, 760 westwood Plaza, Univ. of Calif., Los Angeles, Calif.

106. I. Pope

107. H. Punnett

108. G. Romeo

109. J. Rary

110. J. Robbins \& A. Andrews

111. F. Ruddle

112. S. Sassa

113. A. Schinzel

114. J. Schneider
- Dept. of Ped., Box 63, Madigan Army Med. Cntr., Tacoma, Wash. 98431

- Dept. of Cytogenetics, St. Christopher's Hosp., 2600 N. Lawrence St., Philadelphia, Pa. 19133

- Dept. of Human Genetics, Stanford Med. Sch., Stanford, Calif. 94305

- Rm. 203, Biophysics Bldg., Johns Hopkins Med. Sch., Baltimore, Md. 21205

- Bldg. 10, Rm. 12N 258, National Cancer Inst., National Inst. of Health, Bethesda, Md. 20014 A. Andrews currently at Columbia Univ., New York, N.Y.

- Human Genetics and Biology, Dept. of Biology, Kline Biology Tower, Yale Univ., New Haven, Conn. 06520

- Rockefeller Univ., 66th St. and York Ave., New York, N.Y. 10021

- Kinderspital Zurich, Eleonorenstiftung Universitats-Kinderlink, Steinwiesstrasse 75 , 8032 Zurich, Postcheckkonto 80-2115, Switzerland - Dept. of Ped., Univ. of Calif., San Diego, P.0. Box 109, La, Jolla, Calif. 92037 
115. R. Schmickle

116. B. Schuh

117. J. Schulman

118. C. $S \cot t$

119. M. Seabright

120. J. Seegmiller

121. S. Sega 1

122. L. Shih

123. V. Shih

124. C. Silbert

125. M. Siniscalco
- Dept. of Ped., Birth Defects Diagnostic Program, 2015 Halden Perinatal Research B1dg., Univ. Hosp., Ann Arbor, Mich. 48104

- Woodbridge State School, Woodbridge, N.J. 07905

- Bldg. 10, Rm. 13N-256, National Inst. of Health, Bethesda, Md. 20014

- Univ. of Wash. Med. Sch., Seattle, Wash. 98195

- Wessex Regiona1 Cytogenetics Unit, Pathology Dept., General Infirmery, Salisbury SP2 7SX Great Britain

- Dept. of Med. M-013, Sch. of Med., Univ. of California at San Diego, La Jolla, Calif. 92093

- Dept. of Ped. and Med., Children's Hosp. of Philadelphia, 34th and Civic Cntr. Blvd., Philadelphia, Pa. 19104

- Dept. of Ped., New Jersey Co11. of Med. 100 Bergen St., Newark, N.J. 07103

- Dept. of Neurology, Harvard Med. Sch., Boston, Mass. 02115

- Boston Veterans Adm. Hosp., Endocrine Diabetes Section, 150 South Huntington Ave., Boston, Mass.

- 6th Floor, Rm. 608K, Kettering Bldg., 425 E. 68th St., New York, N.Y. 10023 
126. W. Sly

127. N. Soter

128. B. States

129. D. Steinberg

130. R. Stevenson

131. G. Sunmer

132. R. Summitt

133. M. Swift

134. G. Thomas

135. L. Toji
- Dept. of Ped., Washington Univ. Sch. of Med., Children's Hosp. of St. Louis, $500 \mathrm{~s}$. Kingshighway, St. Louis, Mo. 63110

- Robert B. Brigham Hosp., 125 Parker Hill Ave., Boston, Mass. 02120

- Children's Hosp. of Philadelphia, 34 th and Civic Cntr. Blvd., Philadelphia, Pa. 19104

- Dept. of Med., Div. of Metabolic Disease, Univ, of Calif. Sch. of Med. of San Diego, Basic Science Bldg., La Jolla, Calif. 92037

- Greenwood Genetic Cntr., 1020 Spring St. at Ellenberg, Greenwood, S.C. 29646

- Dept. of Biochemistry, Sch. of Med., Univ. of North Carolina at Chapel Hill, Chapel Hill, N.C. 27514

- Prof. of Ped., Genetics Section, Univ. of Tennessee, 860 Madison Ave., Memphis, Tenn. 38163

- Dept. of Med., Child Develop. Inst., Univ. of North Carolina, Chapel Hill, N.C. 27514

- John Kennedy Inst., 707 N. Broadway St., Baltimore, Md. 21205

- Institute for Medical Research, Copewood St., Camden, N.J. 08103

136. W. Tourtellotte - Neurology Service - 180, Wadsworth VA Hosp. Wilshire and Sawtelle Blvds., Los Angeles, Calif. 90073 
137. W. Turner

138. D. Wenger

139. B. Williamson

140. A. Wirtz

141. R. Worton

143. E. Zackai

144. S. Young

145. R. Weber

146. R. Warwick \& W. Tourtellotte

147. S. Pinne11
- Dept. of Mental Hygiene, Long Island Research Inst., Central Islip, N.Y. 11722

- B.F. Stolinsky Research Lab., Dept. of Ped. Univ. of Colorado Med. Cntr., 4200 E. Ninth Ave., Denver, Colo. 80220

- 2234 Fourteenth St., Rock Is land, I11. 61201

- Kinderpoliklinik der Universtat Munchen, Genetische Beratungstelle Chromasomenlabor, 8 Munchen 2, Pettenkoferstrasse 8a, W. Germany - Hosp. for Sick Children, 555 University Ave., Toronto, Ontario M5G 1 X8, Canada

142. D. Wurster-Hill - Dept. of Pathology, Dartmouth Med. Sch., Hanover, N.H. 03755

- Children's Hosp. of Philadelphia, 34th and Civic Cntr. Blvd., Philadelphia, Pa. 19104 - Genetics Lab., William S. Hall Psychiatric Inst., P.O. Box 119, Columbia, S. C. 29202

- Dept. of Ped., Univ. of Kansas Med. Cntr., Col1. of Health Sciences and Hosp., Rainbow Blvd. at 39th St., Kansas City, Kansas 66103

- Human Specimen Bank, Veterans Admin., Wadsworth Hosp. Cntr., Wilshire and Sawtelle Blvd., Los Angeles, Calif. 90073

- Dermatology Div., Dept. of Med., M3135, Duke Univ. Hosp., Durham, N.C. 27710 
148. B. Emanue1

149. E. Magenis

150. T. Mohandas

151. S. Soukup

152. W. Nichols

153. D. Harris

154. J. O'Brien

155. A. Andrews \&

$\mathrm{J}$. Robbins

156. S. Vasso

157. A. Narvaez
- Dept. of Cytogenetics, Children's Hosp. of Philadelphia, One Children's Cntr., 34 th and Civic Cntr. Blvd., Philadelphia, Pa. 19104

- Dept. of Med. Genetics, Univ. of Oregon Health Science Cntr., P.0. Box 574, Portland, Ore. 97207

- UCLA Med. Sch., Harbor Gen. Hosp., Torrance, Calif.

- Children's Hosp. Research Fdn., Elland and Bethesda Ave., Cincinnati, Ohio 45229

- Institute for Medical Research, Copewood St., Camden, N.J. 08103

- Children's Hosp. of Philadelphia, 34th and Civic Cntr. Blvd., Philadelphia, Pa. 19104

- Dept. of Neurosciences, Univ. of California Sch. of Med. at San Diego, La Jolla, Calif. 92037

- Dept. of Dermatology, Coll. of Physicians and Surgeons, Columbia Univ., 650 W. 168th St., New York, N.Y. 10032; A. Andrews formerly with J. Robbins at NCI-NIH, Bethesda, Md.

- Our Lady of Lourdes Hosp., Haddon Ave. Camden, N.J. 08103

- Wilmington Medical Cntr., Wilmington, Del. 19805 
158. P. Ledger

Y. Ikawa

159. D. Murphy

160. G. D'Angio

161. L. Diamond

162. M. Ampola

163. R. Brumback

164. D. Carpenter

165. J. Chemke

166. W. Clark

167. G. Dawson

168. C. Epstein

169. U. Wiesmann/ H. Aebi
- National Inst. of Health, Bethesda, Md. 20014

I1

11

- National Inst. on Aging, Landow Bldg., C-703, Public Health Service, Bethesda, Md. 20014

- Children's Hosp. of Philadelphia, 34th and Civic Blvd., Philadelphia, Pa. 19104

- Wistar Institute, $36 \mathrm{th}$ and Spruce Sts., Philadelphia, Pa. 19104

- New England Med. Cntr. Hosp., 171 Harrison Ave., Boston, Mass. 02111

- Bldg. 10, Rm. 10D16, Med. Neurology Branch, NINCDS-NIH, Bethesda, Md. 20014

- Sunland Hosp. at Orlando, P.0. Box 3513, Orlando, Fla. 32802

- Clinical Genetics Unit, Kaplan Hosp., Rehovoth, Israe 1

- Dept. of Pathology, Hartford Hosp. Hartford, Conn. 06115

- Dept. of Ped., Univ. of Chicago Hosp. and Clinic, 5825 S. Maryland Ave., Chicago, I11. 60637

- Dept. of Med. Genetics, Rm. 1421 HSW, Univ. of California Sch. of Med., San Francisco, Calif. 94143

- Universitat Bern, Klinik fur Kinderkrankheiten, Freiburgstrasse 23, 3008 Bern, Switzerland 
170. T. Jenkins

171. C. Leier

172. E. Lieber

173. M. Mendiones

174. J. Miller

175. H. Moser

176. P. Reardon

177. B. Vanderheiden

178. R. Vincent

179. W. Wasdah 1

180. P. Winchester
- Dept. of Human Genetics, South African Inst. for Med. Res., Hospital St., Box 1038, Johannesburg 2001, South Africa

- Div. of Cardiology, Ohio State Univ. Hosp., 410 W. 10th Ave., Columbus, Ohio 43210

- Div. of Med. Genetics, Long Island Jewish Hillside Med. Cntr., New Hyde Park, N.Y. 11040

- 835 North Hillside, Wichita, Kansas 67214

- Donald H. Paterson Med. Genetics Unit, Mather Bldg., Univ. of British Columbia, Vancouver, British Columbia, Canada

- John Kennedy Inst., 707 N. Broadway, Baltimore, Md. 21205

- Div. of Cytogenetics, Rm. L-5085, Sch. of Med., University of Connecticut Health Cntr., Farmington, Conn. 06032

- Div. of Biochemistry, Dept. of Clinical Res., Eastern Pennsylvania Psychiatric Inst., Henry Ave. and Abbottsford Rd., Philadelphia, Pa. 19129

- Pathology Dept., Med. Co11. of South Carolina, Charleston, S.C. 29401

- Dept. of Pathology, Univ. of North Dakota, Grand Forks, N.D. 58202

- Cornel1 Univ. Med. Sch., Dept. of Radiology, 525 E. 68th St., New York, N.Y. 10021 
181. S. Wood/S. Styles- Dept. of Med. Genetics, Univ. of British Columbia, Vancouver B.C., V6T IW5 Canada

182. A. A1 Saadi

184. J. Menkes

183. J. Tischfield

185. A. Keyser

187. J. Cortner

188. S. Latt

186. S. Folstein

189. R. Kennett

190. G. Darlington

191. X. Breakfield
- Dept. of Anatomic Pathology, William Beaumont Hosp., 3601 W. 13 Mile Rd., Royal Oak, Mich. 48072

- Dept. of Biology, Case Western Reserve Univ., Cleveland, Ohio 44106

- 9615 Brighton Way, Beverly Hills, Calif. 90210

- Dept. of Biochemistry, Northwestern Univ. Med. Sch., 303 E. Chicago Ave., Chicago, I11. 60611

- Johns Hopkins Hosp., 601 N. Broadway, Baltimore, Md.

- Children's Hosp. of Philadelphia, 34th and Civic Cntr. Blvd., Philadelphia, Pa. 19133

- Dept. of Ped., Harvard Med. Sch., Children's Hosp. Med. Cntr., 300 Longwood Ave., Boston, Mass. 02115

- Dept. of Human Genetics and Cell Culture Cntr., Univ. of Pennsylvania Med. Sch., Richards Bldg. G/4, Philadelphia, Pa. 19174 - Div. of Med. Genetics, Cornell Med. Sch., New York, N.Y. 10021

- Dept. of Human Genetics, Sch. of Med., Yale Univ. 333 Cedar St., New Haven, Conn. 06510 
192. A. Bank

- Dept. of Med., Coll. of Physicians and Surgeons, Columbia Univ., 630 W. 168th St., New York, N.Y. 10032

193. Not assigned

194. P. Eng

195. Mulvihill

196. K. Grinberg

197. W. Reichel

198. N. Felberg

199. G. Lazarus

200. W. Read

201. N. Boschkow

202. A. Miranda

203. L. Rifas
- St. Peter's Med. Cntr., New Brunswick, N.J.

- NCI, Epidemiology, Landow B1dg., Rm. A521C, Bethesda, Md. 20014

- Institute of Medical Genetics, Academy of Med. Science, USSR

- Franklin Square Hosp., 9000 Franklin Square Dr., Baltimore, Md. 21237

- Wills Eye Hosp., 1605 Brandywine St., Philadelphia, Pa. 19130

- Div. of Dermatology, Duke Univ. Med. Cntr., Durham, N.C. 27710

- 110 Munn Lane, Cherry Hi11, N.J. 08034

- Director of Med. Genetics, Cancer Research Cntr., 1154783 Kashivskaye, Chaussee, Moscow USSR

- Dept. of Neurology, Rm. 236, 14th Floor, Vanderbilt Bldg., Coll. of Physicians and Surgeons, Columbia Univ., 630 W. 168th St., New York, N.Y. 10032

- Cel1 Culture Lab., Dept. of Biochemistry, Albert Einstein Col1. of Med., Yeshiva Univ., 1300 Morris Park Ave., Bronx, N.Y. 10461 

Genetics, 500 S. Kingshighway, St. Louis, Mo. 63110 
References to descriptive articles published in Cytogenetics and Cell Genetics on cell cultures in the Human Genetic Mutant Cell Repository.

1. An $(x ; 14)$ translocation, balanced, 46 chromosomes. Repository identification No. GM-73. J. Opitz, P.D. Pallister. Cytogenetics. Cell Genet. 12;289-290 (1973)

2. An $(x ; 14)$ translocation, unbalanced, 47 chromosomes. Repository identification No. GM-74. J. Opitz, P.D. Pallister. Cytogenet. Cell Genet. 12:291-292 (1973)

3. A $(14 ; 22)$ Robertsonian translocation, 45, chromosomes, Repository identification No. GM-5. H.A. Lubs, F.H. Ruddle. Cytogenet. Cell Genet. 12:368-369 (1973)

4. A $(15 ; 18)$ translocation, unbalanced, 45 chromosomes. Repository identification No. GM-17. D.S. Borgaonkar. Cytogenet. Cell Genet. 12:370-371 (1973)

5. An X, isochromosome X (long arm), 46 chromosomes. Repository identification No. GM-88. D.S. Borgaonkar. Cytogenet. Cell Genet. 12:372-373(1973)

6. A $(6 ; 21)$ translocation, unbalanced, 46 chromosomes. Repository identification No. GM-144. D.S. Borgaonkar, A.E. Greene, L.L. Coriell. Cytogenet. Cell Genet. 13:403-405 (1974) 
7. An $(x ; 1)$ translocation, balanced, 46 chromosomes. Repository identification No. GM-97. H.H. Punnett, M.L. Kistenmacher, A.E. Greene, L.L. Coriel1. Cytogenet. Cell Genet. 13:406-407 (1974)

8. An $(8 ; 12)$ translocation, balanced, 46 chromosomes. Repository identification No. GM-213. C.C. Lin, I. Uchida, H. Hotz, R.C. Miller, A.E. Greene, L.L. Corie11. Cytogenet. Cell Genet. $14: 78-79(1975)$

9. A $(17 ; 22)$ translocation, balanced, 46 chromosomes. Repository identification No. GM-119. M.N. Macintyre, J.M. Hempe1, D.B. Walden, R.C. Miller, A.E. Greene, L.L. Coriell. Cytogenet. Ce11 Genet. 14:80-81 (1975)

10. A $(1 ; 17)$ translocation, balanced, plus trisomy 21,47 chromosomes. Repository identification No. GM-201. A. de 1a Chapelle, R.C. Miller, A.E. Greene, L.L. Coriell. Cytogenet. Ce11 Genet. 14:82-83 (1975)

11. A $(1 ; 15)$ translocation, balanced, 46 chromosomes. Repository identification No. GM-126. G.H. Prescott, B.K. McCaw, B.E. Tolby, F. Hecht, R.C. Miller, A.E. Greene, L.L. Coriell. Cytogenet. Cell Genet. 14:84-85 (1975)

12. A $(7 ; 10)$ translocation, balanced, 46 chromosomes. Repository identification No. GM-44. R.C. Miller, C. Bradt, W.W. Nichols, T.S.S. Mao, N.Y. Yolken, L.L. Corie11, A.E. Greene. Cytogenet. Cel1 Genet. $14: 86-87$ (1975) 
13. A $(10 ; 17)$ translocation, balanced, 46 chromosomes. Repository identification No. GM-216. E. Zackai, W. Mellman, M. Aronson, R.C. Miller, A.E. Greene, L.L. Coriell. Cytogenet. Cell Genet. $14: 88-89(1975)$

14. A $(10 ; 17)$ translocation, unbalanced, 46 chromosomes. Repository identification No. GM-217. E. Zachai, W. Mellman, M. Aronson, R.C. Miller, A.E. Greene, L.L. Coriell. Cytogenet. Cel1 Genet. 14:90-91 (1975)

15. A $(17 ; 19)$ translocation, balanced, 46 chromosomes. Repository identification No. GM-271. H.J. Kim, L.Y.F. Hsu, K. Hirschhorn, R.C. Miller, A.E. Greene, L.L. Coriell. Cytogenet. Cel1 Genet. 14:92-93 (1975)

16. A $(4 ; 11)$ translocation, balanced, 46 chromosomes. Repository identification No. GM-380. B.G. Kousseff, H.J. Kim, L.Y.F. Hsu, K. Hirschhorn, R.C. Miller, A.E. Greene, L.L. Coriell. Cytogenet. Cel1 Genet. 14:150-151 (1975)

17. A $(4 ; 21)$ translocation, unbalanced, 46 chromosomes. Repository identification No. GM-98. M. Seabright, R.C. Miller, A.E. Greene, L.L. Coriell. Cytogenet. Cell Genet. 14:152$153(1975)$

18. A $(1 ; 2)$ translocation, balanced, 46 chromosomes. Repository identification No. GM-257. O.S. Alfi, R.C. Miller, A.E. Greene, L.L. Coriell. Cytogenet. Cell Genet. 14:154-155 (1975) 
19. A $(13 ; 22)$ Robertsonian translocation, 45 chromosomes. Repository identification No. GM-392. O. Alfi, R.C. Miller, A.E. Greene, L.L. Coriell. Cytogenet. Cell Genet. 15:55-56 (1975)

20. A (13) terminal deletion, 46 chromosomes. Repository identification No. GM-250. M. Aronson, E. Zackai, W. Mellman, R.C. Miller, A.E. Greene, L.L. Coriel1. Cytogenet. Cel1. Genet. 15:57-58 (1975)

21. A ring 9 chromosome. Repository identification No. GM-166. M.L. Kistenmacher, H.H. Punnett, M. Aronson, R.C. Miller, A.E. Greene, L.L. Corie11. Cytogenet. Cell Genet. 15:122$123(1975)$

22. A $(4 ; 15)$ translocation, balanced, 46 chromosomes. Repository identification No. GM-624. G. Kohn, M.M. Cohen, M. Aronson, R.C. Miller, A.E. Greene, L.L. Coriell. Cytogenet. Cell Genet. 15:124-125(1975)

23. A $(4 ; 11)$ translocation, balanced, 49. XXXXY karyotype. Repository identification No. GM-157. A. de la Chapelle, R.C. Miller, A.E. Greene, L.L. Coriell. Cytogenet. Cell Genet. $15: 127-128(1975)$

24. Fucosidosis type 2. Repository identification Nos. GM-289 to GM-292. N.G. Beratis, B.G. Kousseff, K. Hirschhorn, A.E. Greene, L.L. Coriel1. Cytogenet. Cell Genet. 15:195-197 (1975) 
25. Galactosemia. Repository identification Nos. GM-52 and GM-53. W.J. Mellman, T.A. Tedesco, A.E. Greene, L.L. Coriel1. Cytogenet. Cel1 Genet. 15:198-199 (1975)

26. Homozygous familial hypercholesterolemia (receptor-negative type). Repository identification No. GM-361. J.L. Goldstein, M.S. Brown, A.E. Greene, L.L. Corie11. Cytogenet. Cell Genet. $15: 357-359(1975)$

27. A double translocation culture $t(5 ; 15) t(9 ; 11)$ with partial deletion of the short arm of chromosome 5. Repository identification No. GM-344. L. Jackson, M. Barr, M. Aronson, A.E. Greene, L.L. Coriel1. Cytogenet. Cel1 Genet. 15:400-401 (1975)

28. A $(6 ; 18)$ translocation, 46 chromosomes. Repository identification No. GM-610. H.P. Klinger, M.M. Aronson, A.E. Greene, L.L. Coriel1. Cytogenet. Cell Genet. 15:402-403 (1975)

29. An $(X ; 3)$ translocation, balanced, 46 chromosomes. Repository identification No. GM-194. A. de la Chapelle, J. Schroder, H.P. Klinger, M.M. Aronson, R.C. Miller, A.E. Greene, L.L. Coriell. Cytogenet. Cell Genet. 15:404-405 (1975)

30. A $(13 ; 22)$ translocation, 46 chromosomes. Repository identification No. GM-627. H.J. Kim, K. Hirschhorn, L.Y.F. Hsu, M.M. Aronson, A.E. Greene, L.L. Coriell. Cytogenet. Cell Genet. 15:406-407 (1975) 
31. A $(Y ; 15)$ translocation, 46 chromosomes. Repository identification No. GM-118. N. Hahnemann, R.C. Miller, A.E. Greene, L.L. Coriel1. Cytogenet. Cell Genet. 15:408-409 (1975)

32. Beta-Glucuronidase deficiency mucopolysaccharidosis. Repository identification No. GM-121. W.S. S1y, A.E. Greene, L.L. Corie11. Cytogenet. Cel1 Genet. 15:410-412 (1975)

33. A $(14 ; 15)$ Robertsonian translocation, 45 chromosomes. Repository identification No. GM-479. M.S. Golbus, C.J. Epstein, M.M. Aronson, A.E. Greene, L.L. Coriel1. Cytogenet. Cel1 Genet. 17:61 (1976).

34. Galactosemia. Repository identification Nos. GM-438 to GM-442. S. Kaffe. N.G. Beratis, K. Hirschhorn, A.E. Greene, L.L. Coriell. Cytogenet. Ce11 Genet. 17:62-64 (1976).

35. Maroteaux-Lamy Syndrome. Repository identification Nos. GM-519, 520, 935, 942 and 1022. N.G. Beratis, K. Hirschhorn, S. Friedman A.E. Greene, L.L. Corie11. Cytogenet. Cell Genet. 17:236-238 (1976).

36. Deletion of the short arm of chromosome 5 from a subject with cri-du-chat syndrome. Repository identification No. GM-71. W.R. Breg, M.M. Aronson, A.E. Greene and L.L. Coriell. Cytogenet. and Cell Genet. 17:239-240 (1976). 
37. A $(10 ; 17)$ translocation, 46 chromosomes. Repository identification No. GM-959. E.H. Zackai, H. Moreno-Fuenmayer, W.J. Mellman, M.M. Aronson, A.E. Greene, L.L. Coriell. Cytogenet. Cel1 Genet. 17:302-303 (1976).

38. A $(2 ; 4)$ translocation, unbalanced, 46 chromosomes. Repository identification No. GM-501. B. Biederman, P. Bowen, M.M. Aronson, A.E. Greene, L.L. Corie11. Cytogenet. Ce11 Genet. 17:298-299 $(1976)$.

39. A (2;4) translocation, balanced, 46 chromosomes. Repository identification No. 1064. B. Biederman, P. Bowen, M.M. Aronson, A.E. Greene, L.L. Coriel1. Cytogenet. Cell Genet. 17:300-301 (1976).

40. Deletion of the short arm of chromosome 9 from a subject with congenital cerebral maldevelopment. Repository identification No. GM-870. W.R. Breg, M.M. Aronson, A.E. Greene and L.L. Coriell. Cytogenet. Ce11 Genet. 17:296-297 (1976).

41. A $(5 ; 14)$ translocation, 46 chromosomes. Repository identification No. GM-589. D.S. Borgaonkar, M.M. Aronson, A.E. Greene, L.L. Corie11. Cytogenet. Cell Genet. 18:242 (1977).

42. A $(9 ; 17)$ translocation, 46 chromosomes. Repository identification No. GM-988. C.C. Lin, A.J. Kavanagh, M.M. Aronson, A.E. Greene, L.L. Coriell. Cytogenet. Cell Genet. 18:244 (1977). 
43. Deletion in the short arm of chromosome No. 2 from a subject with congenital anomalies. Repository identification No. GM-1138.

E. Zackai, B. Emanuel, W.J. Mellman, M.M. Aronson, B. Bozarth, A.E. Greene, L.L. Corie11. Cytogenet. Cell Genet. 18:108 (1977).

44. A $(2 ; 8)$ translocation, 46 chromosomes. Repository identification No. GM-327. R. Worton, M.M. Aronson, A.E. Greene, L.L. Coriell. Cytogenet. Cel1 Genet. 18:243 (1977).

45. Deletion of the short arm of chromosome 4 from a subject with Wolf's syndrome. Repository identication No. GM-72. W.R. Breg, M.M. Aronson, A.E. Greene, L.L. Coriel1. Cytogenet. Cell Genet. $18: 307-308(1977)$.

46. Citrullinemia, argininosuccinate synthetase deficiency. Repository identification No. GM-1044. E. Spector, N. Kennaway, H. Punnett, A.E. Greene, L.L. Corie11. In Press.

47. A ( $4 ; 7)$ translocation, 46 chromosomes. Repository identification No. GM-773. L.G. Jackson, B. Bozarth, M.M. Aronson, A.E. Greene, L.L. Coriell. In Press.

48. Duarte variant-galactosemia heterozygote. Repository identication No. GM-1996. G.N. Donne11, W.G. Ng, O.S. Alfi, A.E. Greene, L.L. Corie11. In Press.

49. A $(4 ; 7)$ translocation, 46 chromosomes. Repository identification No. GM-1220. L.G. Jackson, B. Bozarth, M.M. Aronson, A.E. Greene, L.L. Corie11. In Press. 
HL-A antigens of human lymphocyte cell cultures listed on pages 107 through 122. The Human Genetic Repository is indebted to Dr. Roger Kennett, Department of Human Genetics, University of Pennsylvania Medical School, Philadelphia, Pennsylvania.

For further data showing reactions with a selected set of NIH antisera, contact Dr. Kennett.

\begin{tabular}{|c|c|c|c|}
\hline GM \# & $\mathrm{HL}-\mathrm{A}$ & GM 非 & $\mathrm{HL}-\mathrm{A}$ \\
\hline 235 & $(\mathrm{Aw} 31,33) \mathrm{A} 9, \mathrm{Bw} 15, \mathrm{~B} 12$ & 1366 & $\mathrm{~A} 2(\mathrm{~A} 9), \mathrm{B} 8, \mathrm{~B} 12$ \\
\hline 558 & $\mathrm{~A} 3, \mathrm{~A} 11, \mathrm{Bw} 15, \mathrm{Bw} 22$ & 1410 & $\mathrm{~A} 2, \mathrm{Aw} 24, \mathrm{Bw} 35, \mathrm{~B} 13(\mathrm{~B} 12)$ \\
\hline 892 & $\mathrm{~A} 2(\mathrm{~A} 9), \mathrm{B} 12, \mathrm{~B} 18$ & 1446 & $\mathrm{~A} 2,3, \mathrm{Bw} 35, \mathrm{Bw} 17$ \\
\hline 1027 & $\mathrm{~A} 2-\mathrm{B} 12 / \mathrm{A} 1-\mathrm{B} 8$ & 1447 & $\mathrm{~A} 1, \mathrm{Al0}, \mathrm{B} 7,(\mathrm{Bw} 16)$ \\
\hline 1028 & $\mathrm{~A} 1 / \mathrm{A} 2-\mathrm{B} 12$ & 1454 & $\mathrm{~A} 28, \mathrm{~A} 2, \mathrm{Bw} 40, \mathrm{Bw} 21$ \\
\hline 1029 & $\mathrm{~A} 2-\mathrm{B} 12 / \mathrm{A} 28-\mathrm{Bw} 35$ & 1455 & $\mathrm{~A} 11(\mathrm{~A} 3), \mathrm{Bw} 22,(\mathrm{Bw} 40)$ \\
\hline 1032 & $\mathrm{~A} 9, \mathrm{~A} 10, \mathrm{~B} 13$ & 1456 & $\mathrm{~A} 1, \mathrm{~B} 13, \mathrm{Bw} 27$ \\
\hline 1056 & A9, 29, B12, Bw15 & 1461 & $\mathrm{~A} 2, \mathrm{~A} 3, \mathrm{Bw} 22, \mathrm{Bw} 40$ \\
\hline 1063 & $\mathrm{~A} 1, \mathrm{~B} 12, \mathrm{Bw} 17$ & 1463 & $\mathrm{~A} 2, \mathrm{~A} 11, \mathrm{~B} 27, \mathrm{Bw} 22$ \\
\hline 1204 & $\mathrm{~A} 2-\mathrm{B} 12 / \mathrm{A} 28-\mathrm{B} w 35$ & 1500 & $\mathrm{~A} 2(\mathrm{~A} 3), \mathrm{B} 12, \mathrm{Bw} 15$ \\
\hline 1205 & $\mathrm{~A} 28-\mathrm{Bw} 35 / \mathrm{A} 1-\mathrm{B} 13$ & 1501 & $\mathrm{~A} 3, \mathrm{~A} 9, \mathrm{Bw} 22,(\mathrm{~B} 12)$ \\
\hline 1206 & A11-Bw15/A2-B12 & 1525 & $\mathrm{~A} 28,(\mathrm{Aw} 31,33), \mathrm{B} 12$ \\
\hline 1207 & A11-Bw15/A28-Bw35 & 1526 & $\mathrm{~A} 9, \mathrm{~A} 10, \mathrm{Bw} 17, \mathrm{~B} 13(\mathrm{Bw} 40)$ \\
\hline 1241 & $\mathrm{~A} 3, \mathrm{~A} 10, \mathrm{~B} 13, \mathrm{~B} 12$ & 1528 & $\mathrm{~A} 10,(\mathrm{~A} 3), \mathrm{B} 18, \mathrm{Bw} 22$ \\
\hline 1245 & $\mathrm{~A} 9, \mathrm{~A} 10, \mathrm{~B} 13, \mathrm{~B} 18$ & 1529 & $\mathrm{~A} 10, \mathrm{Aw} 23, \mathrm{~B} 8, \mathrm{~B} 18$ \\
\hline 1261 & $\mathrm{~A} 1, \mathrm{~A} 2, \mathrm{Bw} 15(\mathrm{~B} 18)$ & 1530 & $\mathrm{~A} 2, \mathrm{~A} 11, \mathrm{Bw} 17, \mathrm{Bw} 35$ \\
\hline 1311 & $\mathrm{~A} 10, \mathrm{~A} 11(\mathrm{~A} 3), \mathrm{B} 12$ & 1531 & $A 2,(A 9), B 7,(B w 40)$ \\
\hline 1312 & $\mathrm{~A} 10, \mathrm{~A} 11(\mathrm{~A} 3), \mathrm{B} 12$ & 1532 & $\mathrm{~A} 2, \mathrm{~B} 7, \mathrm{Bw} 22,(\mathrm{~B} 18)$ \\
\hline
\end{tabular}




\begin{tabular}{|c|c|c|c|}
\hline GM 非 & $\mathrm{HL}-\mathrm{A}$ & GM 非 & $\mathrm{HL}-\mathrm{A}$ \\
\hline 1539 & $\mathrm{~A} 3, \mathrm{Aw} 30,(\mathrm{~B} 12), \mathrm{Bw} 15$ & 1814 & $(\mathrm{Al}), \mathrm{A} 2, \mathrm{~A} 11, \mathrm{~B} 8, \mathrm{Bw} 40$ \\
\hline 1553 & $A 28, A 3, B w 22, B 13(B 12)$ & 1815 & $\mathrm{~A} 2, \mathrm{~A} 9, \mathrm{~B} 7, \mathrm{~B} 13(\mathrm{~B} 12)$ \\
\hline 1556 & $\mathrm{~A} 1, \mathrm{~B} 13, \mathrm{~B} 27$ & 1817 & $\mathrm{~A} 10-\mathrm{Bw} 35 / \mathrm{A} 2-\mathrm{Bw} 21$ \\
\hline 1558 & $\mathrm{~A} 10, \mathrm{Aw} 24, \mathrm{~B} 7, \mathrm{Bw} 15$ & 1819 & $\mathrm{~A} 10-\mathrm{Bw} 35 / \mathrm{Aw} 24-\mathrm{B} 13$ \\
\hline 1559 & $\mathrm{~A} 3, \mathrm{~A} 10, \mathrm{Bw} 15, \mathrm{~B} 27$ & 1821 & $\mathrm{~A} 2-\mathrm{Bw} 21 / \mathrm{A} 1-\mathrm{Bw} 22$ \\
\hline 1560 & $A 2,3, B 7, B 18$ & 1823 & $\mathrm{~A} 10-\mathrm{Bw} 35 / \mathrm{A} 28-\mathrm{B} 14$ \\
\hline 1561 & $\mathrm{~A} 10, \mathrm{Aw} 24, \mathrm{Bw} 35,(\mathrm{~B} 12)$ & 1825 & $\mathrm{~A} 2, \mathrm{~A} 3, \mathrm{Bw} 22$ \\
\hline 1562 & $\mathrm{~A} 3, \mathrm{~A} 10, \mathrm{~B} 13, \mathrm{~B} 18$ & 1827 & $\mathrm{~A} 11-\mathrm{B} 12 / \mathrm{A} 2(\mathrm{~A} 28)-\mathrm{Bw} 16$ \\
\hline 1565 & $\mathrm{~A} 28, \mathrm{Aw} 24, \mathrm{~B} 7, \mathrm{Bw} 35$ & 1836 & A28-Bw16/A3-Bw35 \\
\hline 1566 & $A 1, A 28, B 13, B w 35$ & 1838 & $A 28(A 2), A w 30, B 12(B 13), B w 35$ \\
\hline 1655 & $\begin{array}{l}\mathrm{A} 1, \mathrm{~A} 2, \mathrm{~B} 13, \mathrm{Bw17}(\mathrm{B} 23) \\
(\mathrm{Bw} 40)\end{array}$ & 1845 & $\mathrm{Aw} 32-\mathrm{Bw} 22 / \mathrm{A} 2(\mathrm{~A} 28)-\mathrm{Bw} 16$ \\
\hline 1685 & $\mathrm{~A} 1, \mathrm{Aw} 32, \mathrm{~B} 18, \mathrm{~B} 27$ & 1847 & A11-B12/Aw32-Bw22 \\
\hline 1712 & $A w 32, A 10, B w 15, B 14,(A 3)$ & $\begin{array}{l}1853 \\
1855\end{array}$ & Aw32, w24, Bw40, B12 \\
\hline 1715 & $\mathrm{~A} 2, \mathrm{~A} 9, \mathrm{Bw40},(\mathrm{B} 7)$ & 1857 & $\mathrm{~A} 9, \mathrm{~A} 11, \mathrm{~B} 7, \mathrm{Bw} 15$ \\
\hline 1716 & A10, Bw15 & 1861 & $\mathrm{~A} 3, \mathrm{~A} 2 ; \mathrm{B} 27, \mathrm{Bw} 22(\mathrm{Bw} 40)$ \\
\hline 1726 & $\mathrm{~A} 28, \mathrm{Aw} 30, \mathrm{~B} 5, \mathrm{Bw} 16$ & 1867 & $\mathrm{~A} 2, \mathrm{Aw} 30, \mathrm{~B} 12, \mathrm{Bw} 22$ \\
\hline 1775 & Aw30, (Bw40), B13, B5 & 1868 & $\mathrm{~A} 28, \mathrm{~A} 10, \mathrm{Bw} 15, \mathrm{Bw} 16$ \\
\hline 1779 & $A 2,10,(B 18)(B w 35)$ & 1883 & $\mathrm{~A} 28, \mathrm{Bw} 35$ \\
\hline 1785 & $\mathrm{~A} 2, \mathrm{~A} 29, \mathrm{~B} 12, \mathrm{~B} 16$ & 1884 & $\mathrm{~A} 29, \mathrm{Aw} 31,33, \mathrm{~B} 12, \mathrm{Bw} 15$ \\
\hline 1793 & Aw24, B18, B13 & 1885 & $\mathrm{~A} 2, \mathrm{~A} 3, \mathrm{Bw} 35, \mathrm{Bw} 22$ \\
\hline 1805 & $\mathrm{~A} 1, \mathrm{~A} 9, \mathrm{~B} 18,(\mathrm{~B} 13)$ & 1899 & $\mathrm{~A} 2, \mathrm{~A} 11, \mathrm{~B} 18, \mathrm{~B} 5(\mathrm{Bw} 35)$ \\
\hline 1806 & $\mathrm{~A} 1, \mathrm{~A} 2, \mathrm{Bw} 17, \mathrm{~B} 18,(\mathrm{Bw} 22)$ & 1900 & $\mathrm{~A} 2, \mathrm{~A} 28, \mathrm{~B} 18, \mathrm{~B} 5(\mathrm{Bw} 35)$ \\
\hline 1807 & $\mathrm{~A} 1, \mathrm{~A} 2, \mathrm{Bw} 35, \mathrm{~B} 13$ & 1901 & $A 1(A 9), A 11, B 8, B w 35$ \\
\hline 1808 & $\mathrm{~A} 2, \mathrm{~A} 10, \mathrm{~B} 12, \mathrm{~B} 27$ & 1902 & $\mathrm{~A} 2, \mathrm{~A} 11, \mathrm{~B} 13$ \\
\hline 1810 & $\mathrm{~A} 1, \mathrm{~A} 10, \mathrm{~B} 7, \mathrm{~B} 13$ & & \\
\hline
\end{tabular}


1905 A11, Bw35

1913 A2, Aw31, B18, B13

1930 A2, A29, B12, Bw35 
APPENDIX E

NSF CELL CULTURE CENTERS

The Cel1 Culture Centers at the Massachusetts Institute of Technology and the University of Alabama at Birmingham are accepting applications for large scale cell and virus production required for highly meritorious research projects. These centers established by the National Science Foundation are intended to serve as a facility and research resource for scientists throughout the country.

The MIT Center is headed by Dr. Phillips W. Robbins of MIT and Dr. Richard L. Davidson of Harvard Medical School. This facility is designed for large scale monolayer and suspension cultures and has experience with a large number of different cell lines and viruses and also with diploid human fibroblasts. The University of Alabama center is headed by J. Claude Bennett of the Department of Microbiology and Ronald T. Acton of the Diabetes Research and Training Center. This facility is designed for large scale suspension cultures with a capability of producing one kilogram or more of cells per week. Their experience to date is is primarily with lymphoblastoid cell lines. The purpose of these centers is to produce cells and viruses on a large scale in order to allow scientists to conduct novel and important experiments in basic biological research that could not be accomplished with the materials and resources in the investigators' own laboratory. Approval of applications is on 
competitive basis, based on the merit of the research project as evaluated by Centers' Steering Comittees.

Examples of recent activities at the Centers are:

1. Production of $100 \mathrm{mg}$ Sindbis Virus propagated in 200 roller bottles of cells for use in $x-r a y$ structural studies.

2. Production of 750 roller bottles of SV40 transformed BALB 3 T 3 cells for purification and characterization of $\mathrm{T}$ antigen.

3. Growth of 300 liters of mouse leukemia cells for isolation and structural analysis of a specific lysine transfer RNA implicated in the control of cell division.

4. Growth of $3.1 \times 10^{12}$ BW 5147 cells for the isolation and structural analysis of $\mathrm{H}-2 \mathrm{k}$ and Thy-1 alloantigens.

Following approval of an application, the investigator sends a stock of cells or virus to the center. The stock is then grown to the requested amount, under conditions of careful handling and rigorous screening for contaminants (including mycoplasma), and prepared according to the needs of the investigator. Investigators will be asked to pay minimal costs to cover media and other supplies. 
The procedure for applying involves submitting a letter specifying the amount of cell or virus required along with a brief description of the relevant research project and available supporting material. Applications or inquiries should be addressed to:

Mr. Donald Giard

Cel1 Culture Center

E17-321

Massachusetts Institute of Technology

77 Massachusetts Avenue

Cambridge, MA 02139

OR

Dr. Ronald T. Acton

Diabetes Research and Education Hospital

University of Alabama Hospitals and Clinics

18087 th Avenue South

Birmingham, AL 35294 
Abetalipoproteinemia, 109

$A B$ variant, GM2 gangliosidosis, 42

Acatalasemia, 49

Acatalasia, 49

Acid sialidase deficiency, 40

Addison disease and cerebral sclerosis, 51

Adenosine deaminase deficiency, 45

Adenosine phosphoribosyltransferase deficiency, 46

Adrenal hyperplasia, 51, 112

Adrenogenital syndrome, 51, 112

Adrenoleukodystrophy, 51

Agammaglobinemia, 51

Alkaptonuria, 26

Allergic asthmatic, 121

Alzheimer disease of brain, 51, 126

Amino acid metabolism, disorders of, 26-31, 107, 108

Amyloidosis, 31

Amniotic fluid, 105, 106

Andersen disease, 34

Angiokeratoma, diffuse, 40, 41, 105

Animal cell cultures, 124,125

Argininemia, 26, 107

Argininosuccinicaciduria, 26

Aspartylglycosaminuria, 31

Ataxia-telangiectasia, 63,119

Basal cell nevus syndrome, 51, 112

Becker muscular dystrophy, 59

Beckwith-Wiedemann syndrome, 51

Beta-glucuronidase deficiency, 40

Biochemical markers, 99-101

Biochemical mutant conditions, 26-62, 105, 107-118, 123, 126, 127

Bloom syndrome, 63,126

Branched-chain ketoaciduria, 29, 30, 108

Campomelic dwarf, 51

Canavan disease, 52

Carbohydrate metabolism, disorders of, 31-40, 108, 109

Carnitine palmitoyl-CoA transferase deficiency, 40

Cartilage-hair hypoplasia, 52

CNS disorder, unclassified, hereditary, 52

Ceroid-1ipofuscinosis, 40

Chediak-Higashi syndrome, 52

Cholesterol ester storage disease of 1 iver, 40

Chondrodysplasia punctata, 52

Chondrodystrophy, 52

Chromosomal aberrations, 63-101, 105, 106, 119, 120, 127 
Chromosome breakage, syndromes with increased, 63, 64, 119

Citrullinemia, 26, 107

Citrullinuria, 26, 107

Cockayne syndrome, 52, 112

Collagen, hydroxylysine-deficient, 56

Conradi syndrome, 52

Coproporphyria, hereditary, 50

Corneal dystrophy, macular type, 52

Cornelia de Lange syndrome, 52

Cowden disease, 126

Cutanea tarda, 50

Cut is laxa, 53

Cystathionine synthase deficiency, 27, 28, 105, 108

Cystathionuria, 107, 108

Cystic fibrosis, 53, 112, 113

Cystinosis, 26, 27, 105

Debranching enzyme deficiency, 34

Deletion of chromosomes, 95-98

Diabetes mel1itus, 53-55, 113, 114

Duchenne muscular dystrophy, 59

Duffy blood group, 101

Dysautonomia, 55, 114, 115

Dyskeratosis congenita, 55, 115

Dystonia musculorum deformans, 55, 115

Ehier-Danlos syndrome, 56

EMG syndrome, 51

Fabry disease, $40,41,105$

Fanconi anemia, 63, 64

Farber 1ipogranulomatosis, 41

Fetal hemoglobin, persistence of, 117

Fructose-1,6-diphosphatase, hepatic deficiency of, 31

Eucosidosis, 31, 32, 108

Galactosenia, kinase deficiency, 32

Galactosemia, transferase deficiency, 32, 33, 105, 109, 123

Gangliosidosis, GMl, 41

Gangliosidosis, GM2, 42

Gaucher disease, 41, 110

Giant mitochondrial disease, 56

Globoid cell sclerosis, 43

Glomus tumor, 127

Glucose-6-phosphate dehydrogenase deficiency and variants, 33

Glycogen storage diseases, 33, 34, 109

Gonadal dysgenesis, 99 
Gouty arthritis, 56

Hamster, Chinese, cultures from, 125

Hamster, Syrian baby, cultures from, 124

Hemoglobin F, persistence of, 117

Hemoglobin S, 50

Hepatolenticular degeneration, 62

Hers disease, 34

Homocystinuria, 27, 28, 105, 108

Hunter syndrome, 38, 105

Huntington chorea, 56-58, 115, 116

Hurler/Scheie, 37, 109

Hurler syndrome, 36, 37, 109

Hypercholesterolemia, familia1, 42, 43, 110

Hyperglycinemia, non-ketotic, 29

Hyperglycinemia, with ketoacidosis and leukopenia, 31

Hyper IgM, 116

Hyperlipidemia, 110

Hyperlipoproteinemia, 42, 43, 110

Hypermethioninemia, 29

Hyperphenylalaninemia, 29

Hyperpyruvicacidemia, 35

Hypophosphatasia, 58

Hypoxanthine guanine phosphoribosyl transferase

(HGPRT) deficiency, 46, 47, 105, 111, 123

Ichthyosis congenita, 58

I-cel1 disease, 35,36

Immune deficiency disease, 45

Incontinentia pigmenti, 58

Inosine triphosphate pyrophosphohydrolase deficiency, 46, 111

Inversions, 89-91, 106

Isochromosome, 95-98

Isovalericacidemia, 29

Kinky hair disease, 49, 111

Known biochemistry, other disorders of, 49, 50, 111, 112

Krabbe disease, 43

Lactic-pyruvic acidosis, 35

Leigh encephalomyelopathy, 59

Lesch-Nyahn sydrome, 46, 47, 105, 111, 123

Leukemia, 121

Lipid metabolism, disorders of, 40-45, 109, 110

Lowe oculocerebrorenal syndrome, 59, 126

Mannosidosis, 35 
Maple syrup urine disease, 29, 30, 108

Marfan syndrome, 59

Maroteaux-Lamy syndrome, 39, 109

McArdle disease, 34

Menkes syndrome, 49, 111

Mental retardation, $x-1$ inked, 59

Metachromatic leukodystrophy, 43, 44, 105, 110

Metaphyseal chondroplasia, McKusick type, 52

Methy lmalonicaciduria, 30

Monosomy, 92

Morquio syndrome, 39

Mouse, cultures from, 124

Mucolipidoses, 35, 36

Mucopolysaccharidoses, 36-40, 109

Mucoviscidosis, 53, 112, 113

Mulibrey nanism, 126

Multiple myeloma, 121, 128

Multiple sulfatase deficiency disease, 44

Muscular dystrophy, 59

Myelogenous leukemia, chronic, 127

Myositis ossificans progressiva, 59

Neuraminidase deficiency, 40

Neuroblastoma, 128

Neurofibromatosis, 59, 60, 117

Normal human cell cultures, apparently, 102-104, 106, 122, 123, 129, 130

Niemann-Pick disease, 44, 45

Nucleotide and nucleic acid metabolism, disorders of, 45-49, 111

Orotic aciduria, 47

Osteogenesis imperfecta, 60

Osteogenic sarcoma, 128

Pancytopenia, 63, 64

Papular mucinosis, 60

Phenylketonuria, 30, 108

Phosphoglycerate kinase deficiency, 40

Phosphorylase kinase deficiency, 34

Polydystrophy, pseudo-Hurler, 36

Polysomy, 93-95, 119, 120

Pompe disease, 34, 109

Porphyria, acute intermittent, 49, 50, 111, 112

Potter syndrome, 60

Progeria, 60, 126

Propionicacidemia, 31

Psychiatric disorders, 61, 117, 118 


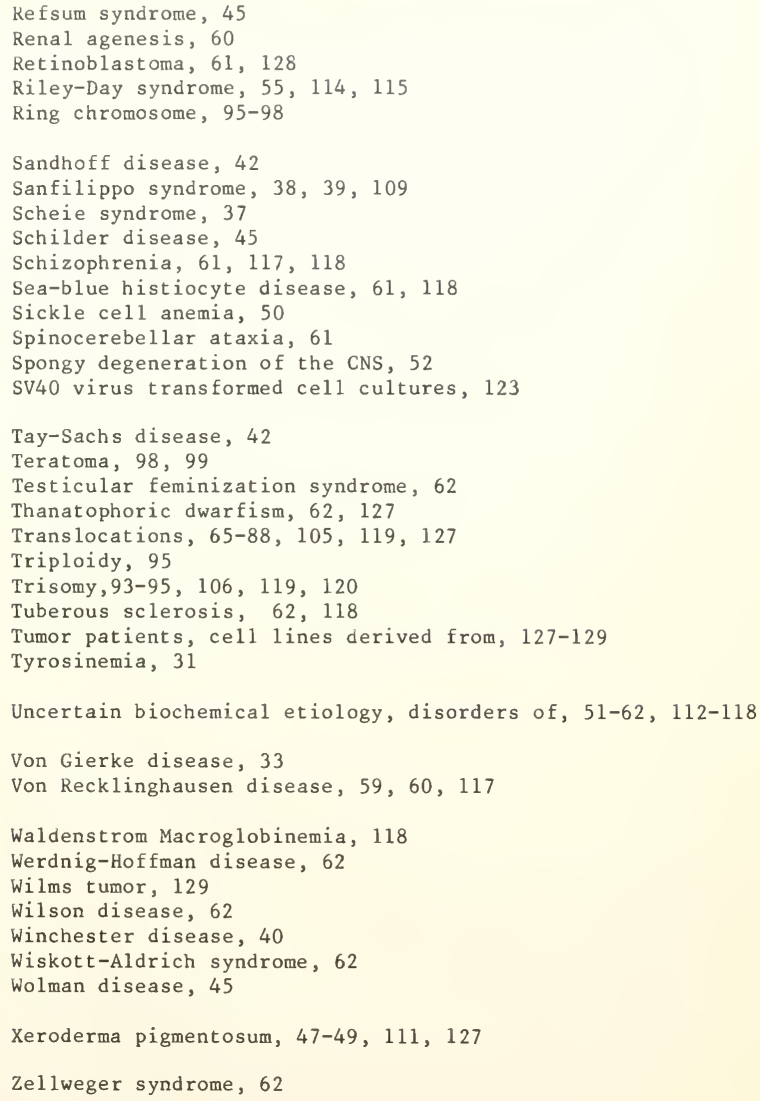




